UNIVERSIDADE DE SÃO PAULO

ESCOLA DE ENGENHARIA DE SÃO CARLOS

DEPARTAMENTO DE HIDRÁULICA E SANEAMENTO

PROGRAMA DE PÓS-GRADUAÇÃO EM CIÊNCIAS DA ENGENHARIA AMBIENTAL

\title{
ESTUDO DO CAMPO TÉRMICO URBANO DE SÃO CARLOS (SP): ANÁLISE DA INTENSIDADE DA ILHA DE CALOR URBANO EM EPISÓDIO CLIMÁTICO DE VERÃO
}

\author{
Arqto. RICARDO VICTOR RODRIGUES BARBOSA
}

Tese apresentada ao Programa de PósGraduação em Ciências da Engenharia Ambiental, da Escola de Engenharia de São Carlos, Universidade de São Paulo, como parte dos requisitos para obtenção do título de Doutor em Ciências da Engenharia Ambiental.

Orientador: Prof. Assoc. FRANCISCO ARTHUR DA SILVA VECCHIA 
AUTORIZO A REPRODUČÃO E DIVULGAÇÃO TOTAL OU PARCIAL DESTE TRABALHO, POR QUALQUER MEIO CONVENCIONAL OU ELETRÓNICO, PARA FINS DE ESTUDO E PESQUISA, DESDE QUE CITADA A FONTE.

Ficha catalográfica preparada pela Seção de Tratamento da Informação do Serviço de Biblioteca - EESC/USP

Barbosa, Ricardo Victor Rodrigues

Estudo do campo térmico urbano de São Carlos (SP) : análise da intensidade da ilha de calor urbano em episódio climático de verão / Ricardo Victor Rodrigues Barbosa; orientador Francisco Arthur da Silva Vecchia. - São Carlos, 2009.

Tese (Doutorado-Programa de Pós-Graduação e Área de Concentração em Ciências da Engenharia Ambiental) -Escola de Engenharia de São Carlos da Universidade de São Paulo, 2009 .

1. Clima. 2. Clima urbano. 3. Campo térmico. 4. Ilha de calor. I. Título. 
Candidato: Arquiteto e Urbanista RICARDO VICTOR RODRIGUES BARBOSA.

Tese defendida e julgada em 09/12/2009 perante a Comissão Julgadora:

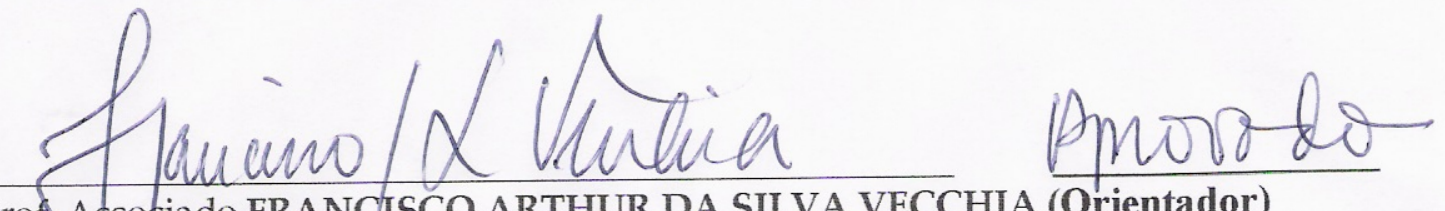

Proß.Associado FRANCISCO ARTHUR DA SILVA VECCHIA (Orientador)

(Escola de Engenharia de São Carlos/USP)
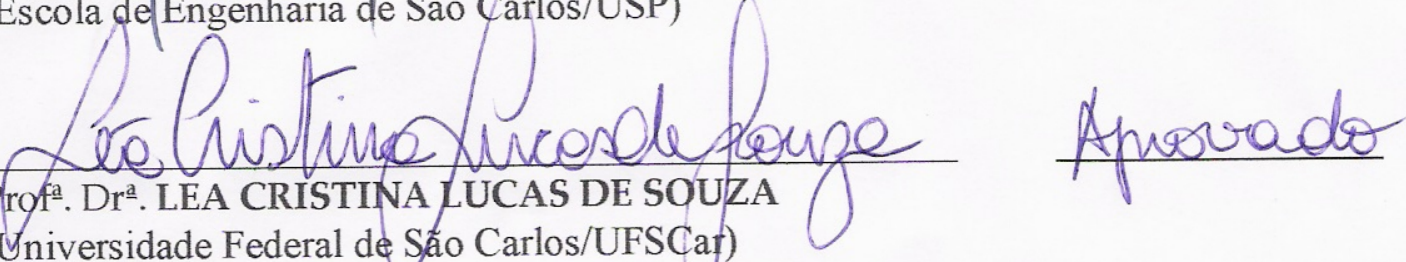

(Universidade Federal de Săo Carlos/UFSCaf)

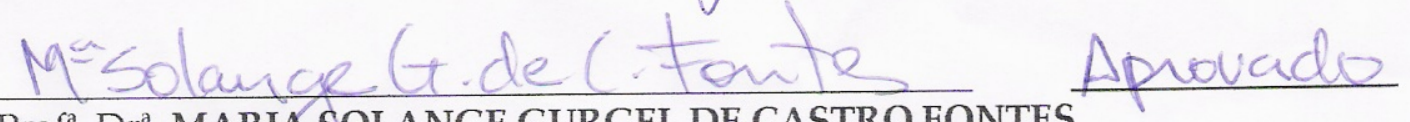

Prof ${ }^{a}$. Dr ${ }^{\mathrm{a}}$. MARIA SOLANGE GURGEL DE CASTRO FONTES

(Universidade Estadual Paulista "Julio de Mesquita Filho"/UNESP/Campus de Bauru)

\section{Ganne mes barbirato}

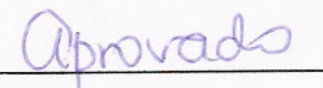

Prof ${ }^{\mathrm{a}}$. Dr ${ }^{\mathrm{a}}$. GIANNA MELO BARBIRATO

(Universidade Federal do Alagoas/UFAL)

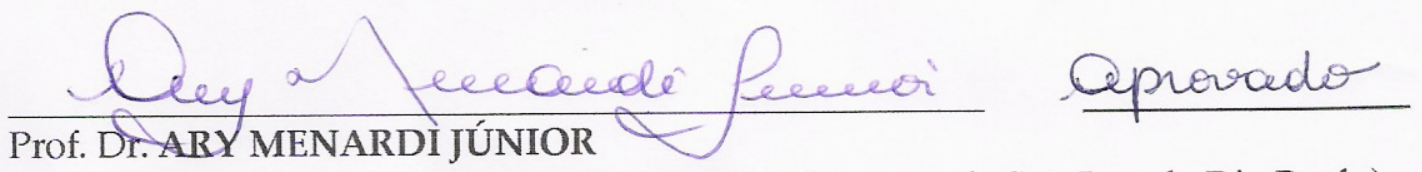

(Faculdade de Filosofia, Ciências e Letras/FFCL/Campus de São Jose do Rio Pardo)

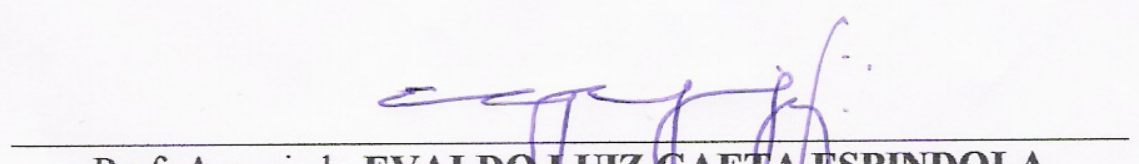

Prof. Associado EVALDO LUIZ GAETA ESPINDOLA

Coordenador do Programa de Pós-Graduação em

Ciências da Engenharia Ambiental

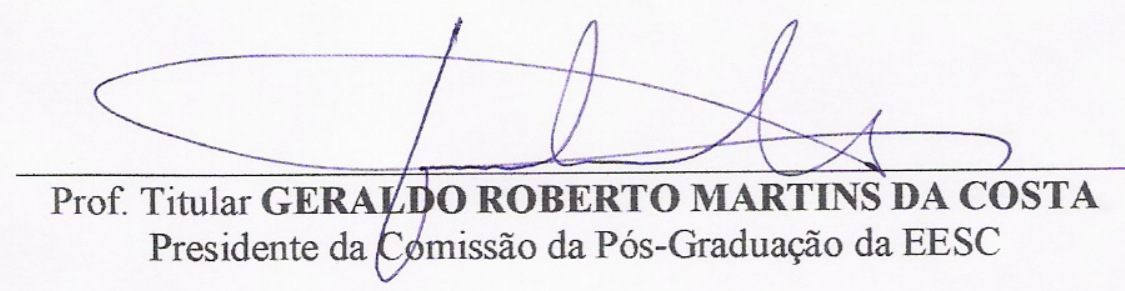



Dedico este trabalho a três pessoas fundamentais nessa conquista: à minha mãe, pelo amor e pelas orações constantes; ao Vicente, pelo apoio incondicional em todos os momentos; e à Roberta, pelo apoio incansável. 


\section{AGRADECIMENTOS}

À Deus, que me concedeu a vida, a saúde e a força de continuar aprendendo.

Aos meus pais, Wandylma e Ronaldo, pelo apoio em todos os momentos e pelo amor dedicado que me tornou a pessoa que sou hoje.

Às minhas irmãs, Roberta e Renata, pelo carinho sempre presente e pelo apoio incondicional no trabalho de campo.

Ao Vicente, grande incentivador e responsável por mais essa conquista.

Ao prof. Dr. Francisco Vecchia, por mais uma vez aceitar-me como orientando e pela confiança depositada no meu trabalho enquanto desbravador nas questões de clima urbano.

À profa. Dra. Gianna Melo Barbirato, por me mostrar o mundo da climatologia urbana durante o período de iniciação científica, pelo incentivo constante no desbravamento dessa temática e pela honra de tê-la como membro na banca de defesa dessa tese.

Aos professores Dr. Ary Menardi Júnior e Dra. Sandra Pitton, pelas observações que contribuíram decisivamente para o desenvolvimento da pesquisa, na fase do exame de qualificação, e pelo aceite em participar como membro na banca de defesa dessa tese.

À profa. Dra. Lea Cristina Souza, pelo aceite em participar como membro na banca de defesa dessa tese.

Aos amigos de laboratório: Gabriel Nolasco, Andrés Quiroa, Caio Beatrice, Marcos Pomps, Pedro Caballero e Richard Pehovaz, pela amizade.

Á amiga e companheira de trabalho Ludimila Fabiana, por compartilhar os momentos de angústia, quando encontrávamos perdido nas questões metodológicas; porém, ainda mais, pelo incentivo constante e pelos momentos de alegria quando encontrávamos o rumo certo.

Ao amigo Marcos Pereira, pela amizade sincera e pelo apoio incansável. 
À Anna Maria Nunes Benini, pelo carinho sincero e por seus cuidados de mãe adotiva que sempre velaram para que eu estivesse bem e em paz; e, ainda, por seu amor aos nordestinos.

Ao amigo e irmão Rogério Herlon, pela amizade sincera e pela companhia alegre e permanente.

Aos amigos arquitetos Cláudio Dornelles e Elisânia Alves, pela amizade sincera, sempre.

Ao prof. Dr. António Lopes, da Universidade de Lisboa, pela paciência e pela prontidão em auxiliar sempre, que, por obra da burocracia não permitiu tê-lo como co-orientador, mas que foi a fonte primária de inspiração dessa tese.

Ao Conselho Nacional de Desenvolvimento Científico e Tecnológico - CNPq, pela concessão de bolsa de doutorado.

Aos inúmeros colaboradores, diretos e indiretos, responsáveis pela conclusão desta tese e que, por um descuido, não foram mencionados nominalmente neste trabalho. Meus agradecimentos. 


\section{RESUMO}

BARBOSA, R. V. R. (2009). Estudo do campo térmico urbano de São Carlos (SP): análise da intensidade da ilha de calor urbano em episódio climático de verão. Tese (Doutorado em Ciências da Engenharia Ambiental) - Escola de Engenharia de São Carlos, Universidade de São Paulo, São Carlos, 2009.

A modificação das condições iniciais do clima é conseqüência inerente da substituição da cobertura natural do solo pelo ambiente construído. Nesse processo, um dos mecanismos do sistema cidade-atmosfera mais afetado pela mudança do uso e da cobertura do solo é o campo térmico urbano. Assim, esta pesquisa objetivou estudar a configuração do campo térmico da cidade de São Carlos nas suas dimensões espaços-temporais, com vistas a conhecer a intensidade da ilha de calor urbano no período de verão, dentro de suas variações diurnas e das condições impostas pelos diferentes tipos de tempo habituais, com o aporte da abordagem dinâmica do clima. A análise da intensidade do campo térmico urbano foi feita a partir de registros de dados climáticos contínuos tomados em superfície por quatro estações automáticas instaladas em diferentes regiões da malha urbana. Os resultados obtidos denotaram que a maior intensidade da ilha de calor urbano, no período de verão, ocorreu na atuação da massa Tropical Atlântica sobre a região, cujo tipo de tempo habitual foi caracterizado por cenário atmosférico com predominância de céu claro, alta incidência de radiação solar direta e valores de temperatura do ar elevados com máxima diária acima da média das máximas indicadas pelas Normais Climatológicas. Sob essas condições, observou-se que as características do entorno construído exerceram maior influência no comportamento térmico urbano, na qual as diferenças térmicas entre diferentes regiões dentro da malha urbana de São Carlos foram superiores a $5^{\circ} \mathrm{C}$. Observou-se, ainda, que a maior expressão da ilha de calor urbano ocorreu após o pôr-do-sol, nos horários entre 21:30h e 22:00h.

Palavras-chave: Clima. Clima urbano. Campo térmico urbano. Ilha de calor. 


\begin{abstract}
BARBOSA, R. V. R. (2009). Study of urban thermal field of São Carlos (SP): analysis of the intensity of urban heat island in summer climatic episode. Thesis (Ph.D. in Environmental Engineering Sciences) - Escola de Engenharia de São Carlos, Universidade de São Paulo, São Carlos, 2009.
\end{abstract}

The initial conditions of the climate are consequence of replacing the natural ground cover by the built environment. In this process, one of the most affected mechanics of the city-atmosphere system due to the change of use and land cover is the urban thermal field. Thus, this research aim to study the configuration of the thermal field of São Carlos in the spatial and temporal dimensions for understanding the intensity of urban heat island in the summer, taking into account its diurnal temperature variations and imposed conditions by different weather types, guided by the climate dynamics approach. The analysis of the intensity of urban thermal field is made from records of climatic data observed in solid ground for four automatic weather stations placed in different areas of the city. The obtained results denote that the highest intensity of urban heat island in summer occurs in the activity of Tropical Atlantic air mass over the region, where the habitual weather was clear skies with high incidence of direct solar radiation and values of air temperature with high daily maximum above the average of the levels indicated by the Climate Normals. Under these weather conditions, it is observed that the characteristics of the built environment have a greater influence on urban thermal behavior, in which the temperature variations between different regions within the urban area of San Carlos were above $5^{\circ} \mathrm{C}$. It is also observed that the highest intensity of urban heat island occurred after sunset, at times between 21:30 and 22:00h.

Key words: Climate. Urban climate. Urban thermal field. Urban heat island. 


\section{RESUMEN}

BARBOSA, R. V. R. (2009). Estudio del campo térmico urbano de São Carlos (SP): análisis de la intensidad de la isla de calor urbano en episodio climático de verano. Tesis (Doctorado en Ciencias de la Ingeniería Ambiental) - Escola de Engenharia de São Carlos, Universidade de São Paulo, São Carlos, 2009.

La modificación de las condiciones iniciales del clima se asocia a la sustitución de la cobertura vegetal natural del suelo por el ambiente construido, En este proceso, uno de los mecanismos del sistema ciudad-atmósfera más afectado por el cambio del uso y cobertura del suelo es el ambiente térmico urbano. En este contexto la presente investigación procuró como objetivo el estudio de la configuración del campo térmico de la ciudad de São Carlos en sus dimensiones espacio-tiempo, con la intensión de conocer la intensidad de la isla de calor urbano en el periodo de verano, dentro de sus variaciones diurnas y de las condiciones impuestas por los diferentes tipos de tiempo comunes, con el aporte del abordaje dinámico del clima. El análisis de la intensidad del campo térmico urbano se hizo a con base en registros de datos climáticos continuos tomados en superficie por cuatro estaciones automáticas instaladas en diferentes regiones del área urbana. Los resultados obtenidos mostraron que la mayor intensidad de la isla de calor urbano, en el periodo de verano, ocurrió en la actuación de la masa Tropical Atlántica sobre la región cuyo tipo de tiempo común fue caracterizado por un escenario atmosférico con predominancia de cielo claro, alta incidencia de radiación solar directa y valores de temperatura del aire elevados con máximas diaria por arriba de la media de las máximas indicadas por las Normales Climatológicas. Sobre estas condiciones, se observó que las características del entorno construido ejercieron mayor influencia en el comportamiento térmico urbano, en la cual las diferencias térmicas entre distintas zonas dentro del área urbana de São Carlos fueron superiores a $5^{\circ} \mathrm{C}$. Se observó, además, que la mayor expresión de la isla de calor urbano ocurrió después de la postura del sol, en el horario entre las 21:30 y las 22:00h.

Palabras clave: Clima. Clima urbano. Campo térmico urbano. Isla de calor. 


\section{LISTA DE FIGURAS}

Figura 1: (a) Localização do estado de São Paulo no Brasil, (b) localização do município de São Carlos no estado de São Paulo e (c) municípios limítrofes e localização geográfica do município de São Carlos.

Figura 2: Mapa simplificado de províncias geomorfológicas do estado de São Paulo, com localização da área de estudo. 20

Figura 3: (a) Mapa geomorfológico do estado de São Paulo, com indicação do traçado do perfil topográfico passando pelo município de São Carlos, na região centro-norte do estado; (b) Perfil topográfico transversal do estado de São Paulo indicando a localização do município de São Carlos no topo das Cuestas Basálticas; (c) Mapa hipsométrico do município de São Carlos com indicação da área urbana.................. 22

Figura 4: Perfil geológico da região de São Carlos. .................................................... 23

Figura 5: Mapa dos principais tipos de solo no município de São Carlos, com indicação da área urbana na cor cinza. 24

Figura 6: Mapa indicativo da porção das duas macro bacias dentro do limite municipal de São Carlos, subdividido em dez microbacias, com indicação da área urbana em cinza.

Figura 7: Expansão da malha urbana de São Carlos, em intervalos de 10 anos, a partir de 1940 até 2002 . . 35

Figura 8: Esquema representativo das feições climáticas individualizadas no território paulista dentro das células climáticas regionais e das articulações destas nas faixas zonais

Figura 9: Totais pluviométricos mensais em São Carlos segundo as Normais Climatológicas (1961-1990) 40

Figura 10: (a) Localização das quatro estações automáticas na malha urbana de São Carlos sobre modelo digital de terreno, mostrando a conformação do revelo na cidade com indicação das diferentes altitudes em cada estação climática; (b) perfil topográfico transversal da área urbana de São Carlos com a localização das quatro estações climáticas adotadas na presente investigação experimental.

Figura 11: (a) Localização da estação Campus I na área urbana de São Carlos e (b) entorno da estação Campus I.

Figura 12: (a)(b) Entorno construído na área do Campus I, com destaque para a densidade de construção e verticalização das construções; (c) densidade de construção e extensa área de solo pavimentado no Campus I da Escola de Engenharia de São Carlos, Universidade de São Paulo; e (d) córrego canalizado no entorno do Campus I.

Figura 13: (a) Localização da estação Campus II na área urbana de São Carlos e (b) entorno da estação Campus II.

Figura 14: (a)(b) Entorno construído na área do Campus II evidenciando o predomínio de edificações térreas, sem recuo em lotes estreitos; (c) extensas áreas abertas sem presença de vegetação arbórea; e (d) a baixa densidade de construção no Campus II, com extensa área de solo gramado.

Figura 15: (a) Localização da estação Fadisc na área urbana de São Carlos e (b) entorno da estação Fadisc. 
Figura 16: (a) (b) Entorno construído na área da Fadisc, com destaque para a baixa densidade de construção, com grande número de lotes vazios. As figuras evidenciam, ainda, a altitude da área no relevo de São Carlos. (c) (d) Extensa área verde com vegetação arbórea que circunda a área da Fadisc.

Figura 17: (a) Localização da estação Samambaia na área urbana de São Carlos e (b) entorno da estação Samambaia.

Figura 18: (a) (b) (c) Entorno construído na área do condomínio residencial Samambaia, com destaque para a baixa densidade de construção e para a vegetação arbórea nas ruas. (d) Extensa área verde com vegetação arbórea que circunda a área da do condomínio residencial Samambaia.

Figura 19: Análise rítmica do episódio climático delineado compreendido entre os dias 20 de fevereiro a 01 de março de 2005 com indicação do sistema atmosférico atuante.

59

Figura 20: Rosa dos ventos com a dinâmica da circulação do ar no dia 20/02/2005, obtidos por meio de registros de direção e velocidade dos ventos tomados por média a cada 30 minutos pela estação automática localizada no Campus I.

Figura 21: (a) Imagem do satélite GOES 12, canal 4 (infravermelho), e (b) carta de pressão ao nível do mar às 9:00h (horário local) do dia 20/02/2005. (c) Análise rítmica horária com registro dos elementos climáticos tomados a cada 30 minutos. 63

Figura 22: Rosa dos ventos com a dinâmica da circulação do ar no dia 21/02/2005, obtidos por meio de registros de direção e velocidade dos ventos tomados por média a cada 30 minutos pela estação automática localizada no Campus I.

Figura 23: (a) Imagem do satélite GOES-12, canal 4 (infravermelho), e (b) carta de pressão ao nível do mar às 9:00h (horário local) do dia 21/02/2005. (c) Análise rítmica horária com registro dos elementos climáticos tomados a cada 30 minutos. 71

Figura 24: Rosa dos ventos com a dinâmica da circulação do ar no dia 22/02/2005, obtidos por meio de registros de direção e velocidade dos ventos tomados por média a cada 30 minutos pela estação automática localizada no Campus I. .78

Figura 25: Imagem do satélite GOES-12, canal 4 (infravermelho), e carta de pressão ao nível do mar às 9:00h (horário local) do dia 22/02/2005 e análise rítmica horária com registro dos elementos climáticos tomados a cada 30 minutos. 79

Figura 26: Rosa dos ventos com a dinâmica da circulação do ar no dia 23/02/2005, obtidos por meio de registros de direção e velocidade dos ventos tomados por média a cada 30 minutos pela estação automática localizada no Campus I. 85

Figura 27: Imagem do satélite GOES-12, canal 4 (infravermelho), e carta de pressão ao nível do mar às 9:00h (horário local) do dia 23/02/2005 e análise rítmica horária com registro dos elementos climáticos tomados a cada 30 minutos.

Figura 28: Rosa dos ventos com a dinâmica da circulação do ar no dia 24/02/2005, obtidos por meio de registros de direção e velocidade dos ventos tomados por média a cada 30 minutos pela estação automática localizada no Campus I. .93

Figura 29: Imagem do satélite GOES-12, canal 4 (infravermelho), e carta de pressão ao nível do mar às 9:00h (horário local) do dia 24/02/2005 e análise rítmica horária com registro dos elementos climáticos tomados a cada 30 minutos.

Figura 30: Rosa dos ventos com a dinâmica da circulação do ar no dia 25/02/2005, obtidos por meio de registros de direção e velocidade dos ventos tomados por média a cada 30 minutos pela estação automática localizada no Campus I. 101

Figura 31: Imagem do satélite GOES-12, canal 4 (infravermelho), e carta de pressão ao nível do mar às 9:00h (horário local) do dia 25/02/2005 e análise rítmica horária com registro dos elementos climáticos tomados a cada 30 minutos. 103 
Figura 32: Rosa dos ventos com a dinâmica da circulação do ar no dia 26/02/2005, obtidos por meio de registros de direção e velocidade dos ventos tomados por média a cada 30 minutos pela estação automática localizada no Campus I. 108

Figura 33: Imagem do satélite GOES-12, canal 4 (infravermelho), e carta de pressão ao nível do mar às 12:00h (horário local) do dia 26/02/2005 e análise rítmica horária com registro dos elementos climáticos tomados a cada 30 minutos. 110

Figura 34: Rosa dos ventos com a dinâmica da circulação do ar no dia 27/02/2005, obtidos por meio de registros de direção e velocidade dos ventos tomados por média a cada 30 minutos pela estação automática localizada no Campus I. 115

Figura 35: Imagem do satélite GOES 12, canal 4 (infravermelho), e carta de pressão ao nível do mar às 9:00h (horário local) do dia 27/02/2005 e análise rítmica horária com registro dos elementos climáticos tomados a cada 30 minutos. 117

Figura 36: Rosa dos ventos com a dinâmica da circulação do ar no dia 28/02/2005, obtidos por meio de registros de direção e velocidade dos ventos tomados por média a cada 30 minutos pela estação automática localizada no Campus I. 123

Figura 37: Imagem do satélite GOES-12, canal 4 (infravermelho), e carta de pressão ao nível do mar às 9:00h (horário local) do dia 28/02/2005 e análise rítmica horária com registro dos elementos climáticos tomados a cada 30 minutos. 124

Figura 38: Rosa dos ventos com a dinâmica da circulação do ar no dia 01/03/2005, obtidos por meio de registros de direção e velocidade dos ventos tomados por média a cada 30 minutos pela estação automática localizada no Campus I. 130

Figura 39: Imagem do satélite GOES-12, canal 4 (infravermelho), e carta de pressão ao nível do mar às 9:00h (horário local) do dia 01/03/2005 e análise rítmica horária com registro dos elementos climáticos tomados a cada 30 minutos. 131 



\section{LISTA DE GRÁFICOS}

Gráfico 1: Comportamento da temperatura do ar na cidade de São Carlos entre os dias 20/02/2005 e 01/03/2005, com indicação da média das máximas e da média das mínimas para o mês de fevereiro fornecidas pelas Normais Climatológicas de 1961 1990.

Gráfico 2: Adaptado da análise do ritmo climático no período compreendido entre o 01 de fevereiro à 03 de março de 2005 com dados registrados pela estação automática localizada no Centro de Recursos Hídricos e Ecologia Aplicada - CRHEA. 58

Gráfico 3: Comportamento da temperatura do ar registrada no dia 20/02/2005 nas quatro estações urbanas. 64

Gráfico 4: Diferenças no comportamento da temperatura do ar registrada no dia 20/02/2005 nas quatro estações urbanas, analisadas duas a duas. 65

Gráfico 5: Matriz de análise do comportamento térmico das quatro estações automáticas no dia 20/02/2005. A leitura horizontal dos gráficos permite acompanhar o comportamento diário de cada estação em relação às demais, indicando maior ou menor aquecimento do ar de acordo com a projeção acima ou abaixo do eixo das coordenadas, respectivamente, enquanto a leitura vertical dos gráficos permite a análise das estações automáticas tomadas a partir de uma estação de referência, indicada acima de cada coluna. 67

Gráfico 6: Comportamento da temperatura do ar registrada no dia 21/02/2005 nas quatro estações urbanas. 72

Gráfico 7: Diferenças no comportamento da temperatura do ar registrada no dia 21/02/2005 nas quatro estações urbanas, analisadas duas a duas. 73

Gráfico 8: Matriz de análise do comportamento térmico das quatro estações automáticas no dia 21/02/2005. A leitura horizontal dos gráficos permite acompanhar o comportamento diário de cada estação em relação às demais, indicando maior ou menor aquecimento do ar de acordo com a projeção acima ou abaixo do eixo das coordenadas, respectivamente, enquanto a leitura vertical dos gráficos permite a análise das estações automáticas tomadas a partir de uma estação de referência, indicada acima de cada coluna. 75

Gráfico 9: Comportamento da temperatura do ar registrada no dia 22/02/2005 nas quatro estações urbanas. 78

Gráfico 10: Diferenças no comportamento da temperatura do ar registrada no dia 22/02/2005 nas quatro estações urbanas, analisadas duas a duas. 81

Gráfico 11: Matriz de análise do comportamento térmico das quatro estações automáticas no dia 22/02/2005. A leitura horizontal dos gráficos permite acompanhar o comportamento diário de cada estação em relação às demais, indicando maior ou menor aquecimento do ar de acordo com a projeção acima ou abaixo do eixo das coordenadas, respectivamente, enquanto a leitura vertical dos gráficos permite a análise das estações automáticas tomadas a partir de uma estação de referência, indicada acima de cada coluna. 83

Gráfico 12: Comportamento da temperatura do ar registrada no dia 23/02/2005 nas quatro estações urbanas. 86

Gráfico 13: Diferenças no comportamento da temperatura do ar registrada no dia 23/02/2005 nas quatro estações urbanas, analisadas duas a duas. 89 
Gráfico 14: Matriz de análise do comportamento térmico das quatro estações automáticas no dia 23/02/2005. A leitura horizontal dos gráficos permite acompanhar o comportamento diário de cada estação em relação às demais, indicando maior ou menor aquecimento do ar de acordo com a projeção acima ou abaixo do eixo das coordenadas, respectivamente, enquanto a leitura vertical dos gráficos permite a análise das estações automáticas tomadas a partir de uma estação de referência, indicada acima de cada coluna.

Gráfico 15: Comportamento da temperatura do ar registrada no dia 24/02/2005 nas quatro estações urbanas.

Gráfico 16: Diferenças no comportamento da temperatura do ar registrada no dia 24/02/2005 nas quatro estações urbanas, analisadas duas a duas.

Gráfico 17: Matriz de análise do comportamento térmico das quatro estações automáticas no dia 24/02/2005. A leitura horizontal dos gráficos permite acompanhar o comportamento diário de cada estação em relação às demais, indicando maior ou menor aquecimento do ar de acordo com a projeção acima ou abaixo do eixo das coordenadas, respectivamente, enquanto a leitura vertical dos gráficos permite a análise das estações automáticas tomadas a partir de uma estação de referência, indicada acima de cada coluna.

Gráfico 18: Comportamento da temperatura do ar registrada no dia 25/02/2005 nas quatro estações urbanas. 102

Gráfico 19: Diferenças no comportamento da temperatura do ar registrada no dia 25/02/2005 nas quatro estações urbanas, analisadas duas a duas. 104

Gráfico 20: Matriz de análise do comportamento térmico das quatro estações automáticas no dia 25/02/2005. A leitura horizontal dos gráficos permite acompanhar o comportamento diário de cada estação em relação às demais, indicando maior ou menor aquecimento do ar de acordo com a projeção acima ou abaixo do eixo das coordenadas, respectivamente, enquanto a leitura vertical dos gráficos permite a análise das estações automáticas tomadas a partir de uma estação de referência, indicada acima de cada coluna. 105

Gráfico 21: Comportamento da temperatura do ar registrada no dia 26/02/2005 nas quatro estações urbanas. 109

Gráfico 22: Diferenças no comportamento da temperatura do ar registrada no dia 26/02/2005 nas quatro estações urbanas, analisadas duas a duas.

Gráfico 23: Matriz de análise do comportamento térmico das quatro estações automáticas no dia 26/02/2005. A leitura horizontal dos gráficos permite acompanhar o comportamento diário de cada estação em relação às demais, indicando maior ou menor aquecimento do ar de acordo com a projeção acima ou abaixo do eixo das coordenadas, respectivamente, enquanto a leitura vertical dos gráficos permite a análise das estações automáticas tomadas a partir de uma estação de referência, indicada acima de cada coluna. 113

Gráfico 24: Comportamento da temperatura do ar registrada no dia 27/02/2005 nas quatro estações urbanas. 116

Gráfico 25: Diferenças no comportamento da temperatura do ar registrada no dia 27/02/2005 nas quatro estações urbanas, analisadas duas a duas.

Gráfico 26: Matriz de análise do comportamento térmico das quatro estações automáticas no dia 27/02/2005. A leitura horizontal dos gráficos permite acompanhar o comportamento diário de cada estação em relação às demais, indicando maior ou menor aquecimento do ar de acordo com a projeção acima ou abaixo do eixo das coordenadas, respectivamente, enquanto a leitura vertical dos gráficos permite a 
análise das estações automáticas tomadas a partir de uma estação de referência, indicada acima de cada coluna 119

Gráfico 27: Comportamento da temperatura do ar registrada no dia 28/02/2005 nas quatro estações urbanas. 123

Gráfico 28: Diferenças no comportamento da temperatura do ar registrada no dia 28/02/2005 nas quatro estações urbanas, analisadas duas a duas. 126

Gráfico 29: Matriz de análise do comportamento térmico das quatro estações automáticas no dia 28/02/2005. A leitura horizontal dos gráficos permite acompanhar o comportamento diário de cada estação em relação às demais, indicando maior ou menor aquecimento do ar de acordo com a projeção acima ou abaixo do eixo das coordenadas, respectivamente, enquanto a leitura vertical dos gráficos permite a análise das estações automáticas tomadas a partir de uma estação de referência, indicada acima de cada coluna. 127

Gráfico 30: Comportamento da temperatura do ar registrada no dia 01/03/2005 nas quatro estações urbanas. 132

Gráfico 31: Diferenças no comportamento da temperatura do ar registrada no dia 01/03/2005 nas quatro estações urbanas, analisadas duas a duas. 133

Gráfico 32: Matriz de análise do comportamento térmico das quatro estações automáticas no dia 01/03/2005. A leitura horizontal dos gráficos permite acompanhar o comportamento diário de cada estação em relação às demais, indicando maior ou menor aquecimento do ar de acordo com a projeção acima ou abaixo do eixo das coordenadas, respectivamente, enquanto a leitura vertical dos gráficos permite a análise das estações automáticas tomadas a partir de uma estação de referência, indicada acima de cada coluna. 135 



\section{LISTA DE QUADROS}

Quadro 1: Causas da ilha de calor urbana, não ordenadas por ordem de importância. 14

Quadro 2: Quadro-síntese dos dados disponíveis nas cinco estações automáticas no período de verão (novembro/04 a março/05) 55

\section{LISTA DE TABELAS}

Tabela 1: Taxa geométrica de crescimento de 1940 a 2000: São Carlos, estado de São Paulo e Brasil.

Tabela 2: Distribuição numérica e percentual das populações urbana e rural do

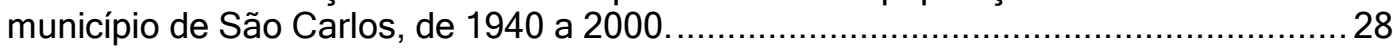

Tabela 3: Normais Climatológicas de São Carlos - período 1961-1990 ....................... 43 



\section{SUMÁRIO}

INTRODUÇÃO

CAPITULO I - O AMBIENTE URBANO COMO MODIFICADOR DAS CONDIÇÕES

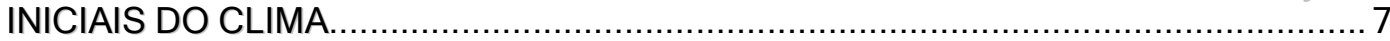

1 O CLIMA URBANO

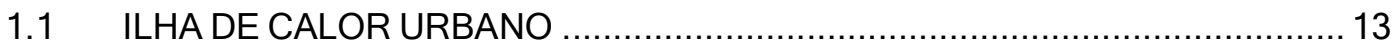

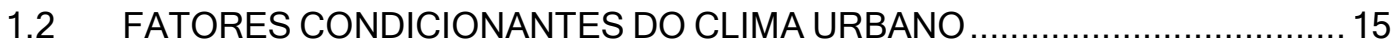

CAPÍTULO II - CARACTERIZAÇÃO E ASPECTOS CLIMÁTICOS DO ECOSSISTEMA

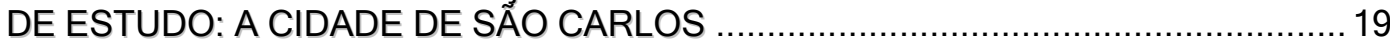

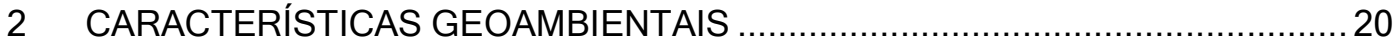

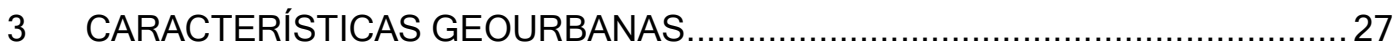

3.1 OCUPAÇÃO DO TERRITÓRIO E CONSOLIDAÇÃO DO NÚCLEO URBANO .28

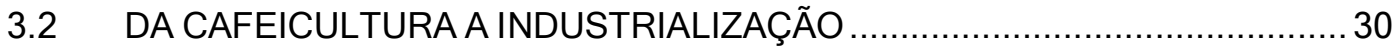

3.3 PROCESSO DE URBANIZAÇÃO E A CONFORMAÇÃO DO TRAÇADO

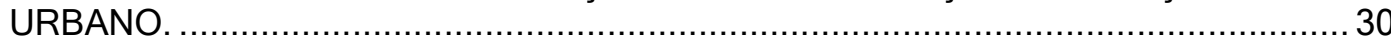

3.4 EXPANSÃO URBANA POR ÁREAS LOTEADAS A PARTIR DA DÉCADA DE 70 E VETORES DE OCUPAÇÃO URBANA EM SÃO CARLOS......................................... 32

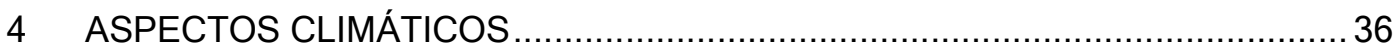

4.1 MASSAS DE AR E CIRCULAÇÃO ATMOSFÉRICA NO ESTADO DE SÃO PAULO: A ESCALA ZONAL NO ÂMBITO DA CIRCULAÇÃO REGIONAL. ....................36 4.2 SUB-UNIDADE CLIMÁTICA V - CENTRO-NORTE: O CLIMA DE SÃO CARLOS NO ÂMBITO DA ESCALA LOCAL..................................................................... 38 4.3 CARACTERÍSTICAS E OS TIPOS DE TEMPO HABITUAIS DO PERÍODO DE VERÃO

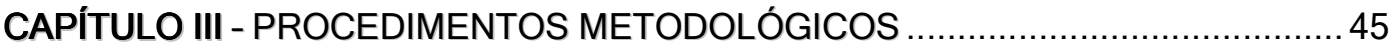

2 AQUISIÇÃO DE REGISTROS CLIMÁTICOS EM SUPERFÍCIE..........................46

2.1 ESTAÇÕES CLIMÁTICAS USADAS NA AQUISIÇÃO DE DADOS EM

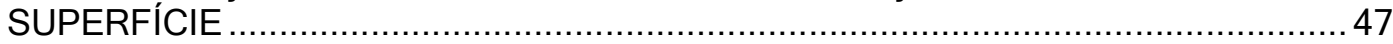

2.2 ORGANIZAÇÃO E TRATAMENTO DOS DADOS CLIMÁTICOS ……….........54

3 DEFINIÇÃO DE UM EPISÓDIO CLIMÁTICO REPRESENTATIVO DO PERÍODO

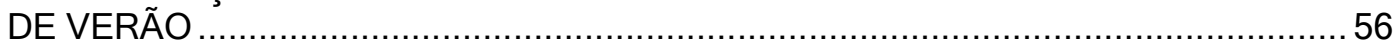

CAPITULO IV - ANÁLISE E DISCUSSÃO DOS RESULTADOS OBTIDOS ….............. 61

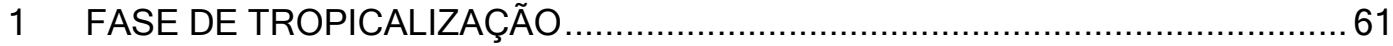

2 FASE DE DOMÍNIO DA MASSA TROPICAL ATLÂNTICA ……………............. 77

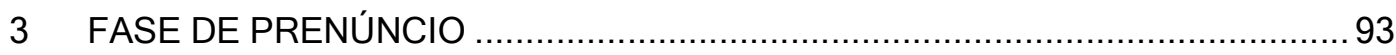

4 FASE DE AVANÇO DO SISTEMA FRONTAL............................................. 98

5 FASE DE DOMÍNIO DA MASSA POLAR ATLÂNTICA ................................... 107

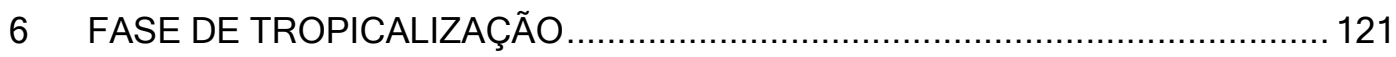

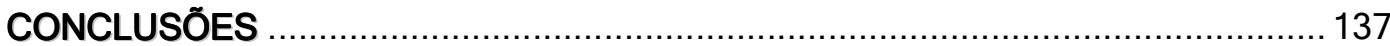

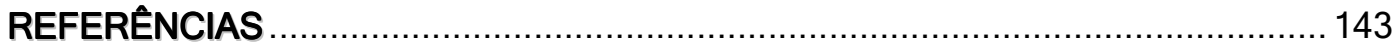

ANEXOS …… 151

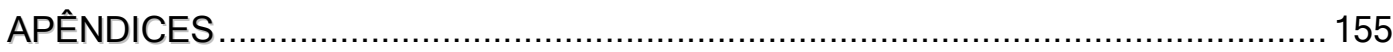





\section{Introdução}

A cidade, inicialmente pequenos centros de comercio e artesões dentro de burgos, sofreu modificações sem precedentes na história da humanidade com a Revolução Industrial, ocorrida na Europa no século XVIII. Esta alterou profundamente as condições de vida do trabalhador braçal, provocando, inicialmente, intenso deslocamento da população rural para as cidades, com enormes concentrações urbanas, mancando, assim, o processo de urbanização e crescimento das cidades. No entanto, a intensidade do adensamento urbano e populacional só atingiu seu auge no século XX - caracterizado como o século da urbanização - impulsionado pelo crescimento do capitalismo financeiro, elemento estruturador e definidor da morfologia espacial urbana até os dias atuais.

Notadamente na maioria dos países latino-americanos, a intensa urbanização ocorreu após a Segunda Guerra Mundial, com o desenvolvimento da atividade industrial. No Brasil, a intensificação da urbanização se deu de forma mais acentuada a partir da década de 60 , impulsionada pelo advento da indústria nacional que serviu como atrativo para o estabelecimento de um grande contingente populacional nas cidades em busca de trabalho e melhores condições de vida (MENDONÇA, 2003a).

Atualmente, as cidades abrigam a maior parte das atividades econômicofinanceiras, sociais e culturais, tornando áreas de grande concentração populacional e de crescente demanda de energia, recursos naturais e matérias-primas. Segundo estimativas da Organização das Nações Unidas - ONU, seis bilhões de pessoas habitavam o planeta no ano 2000 , dentre as quais aproximadamente $50 \%$ do total habitavam em áreas urbanas. Atualmente, estima-se que cerca de 3,2 bilhões de pessoas habitem em áreas urbanas, número que representa $53 \%$ da população mundial. A previsão da ONU é que, em 2050, sete em cada dez pessoas residam em área urbanas em todo o mundo.

O panorama brasileiro segue a tendência mundial. De acordo com dados do último Censo (IBGE, 2000), aproximadamente $81,25 \%$ da população brasileira residem em cidades. Esse número é ainda na região Sudeste, na qual 90,52\% da população habitam em áreas urbanas. Entretanto, diferente da realidade encontrada nos países desenvolvidos, as cidades brasileiras cresceram de forma rápida e desordenada, avançando sobre a paisagem original à revelia do planejamento urbano. Essa prática 
resultou na manifestação de vários problemas relacionados, sobretudo, à sustentabilidade do meio ambiente urbano com comprometimento das condições urbano-ambientais

Sobre esse aspecto, Gottdiener (1993) ressaltou que a forma do espaço urbano é a materialização do desenvolvimento contínuo do capitalismo. A cidade se expande em decorrência da própria dinâmica de reprodução do capital. Assim, os traços característicos da morfologia espacial urbana estão dialeticamente relacionados ao modelo de desenvolvimento adotado. No Brasil, por muito tempo o planejamento de cidades ignorou as conseqüências de modificações ambientais ocasionada pelo processo de expansão urbana. Essa concepção colocou em risco a sustentabilidade do ambiente urbano e tem impulsionado um novo pensar sobre a cidade.

As estimativas evidenciam que caminhamos para um mundo cada vez mais urbano. Assim, deve ser reconhecida a importância dos estudos sobre as cidades e os impactos provenientes da expansão urbana nas modificações dos ecossistemas existentes, com vistas à preservação das condições de sustentabilidade ambiental devido aos impactos das estruturas urbanas sobre as diferentes esferas do sistema natural que a sustentam - hidrosfera, litosfera, pedosfera, biosfera e atmosfera. Dentre eles, vem assumindo cada dia mais importância àqueles relativos ao sistema atmosférico, destacando-se, nessa investigação, as modificações nas condições iniciais do clima pelo processo de urbanização.

Salienta-se, entretanto, que embora seja reconhecida a importância da consideração do clima no planejamento, com vistas à existência de espaços adequados ao conforto do usuário urbano, constata-se que muito pouco do conhecimento disponível da climatologia urbana é usado no planejamento das cidades (ELNAHAS, 1999; ASSIS, 2003). Sob esse aspecto, torna-se imprescindível que profissionais ligados ao planejamento urbano possam dispor de metodologias para análise quantitativa e integrada de atributos da forma urbana e do clima, de modo a mitigar os impactos adversos da expansão urbana na atmosfera.

A partir desse cenário, a presente investigação abordou a temática clima urbano sob o enfoque da influência das características geoambientais e geourbanas na configuração do campo térmico urbano, por meio do estudo da intensidade da ilha de calor. A abordagem foi feita por meio de estudo de caso, tomando como ecossistema de estudo a cidade de São Carlos (SP), localizada na região central do

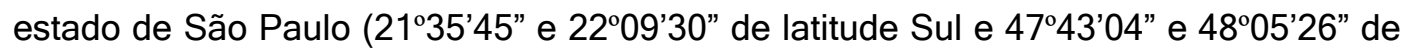
longitude Oeste), na região Sudeste do Brasil. 
A escolha da cidade de São Carlos como ecossistema de estudo foi definida por alguns critérios. São eles: (a) conhecimento prévio da malha urbana pelo autor da pesquisa; (b) disponibilidade de informações como mapas de uso do solo, hipsométrico, padrão habitacional, densidade populacional, etc.; e (c) existência e disponibilidade de registros de dados climáticos horários em superfície de quatro estações automáticas instaladas dentro da malha urbana, provenientes de outras pesquisas dentro da Universidade de São Paulo.

Destaca-se que o clima urbano de São Carlos foi estudado anteriormente por Souza (1996) e Fontes (1998). Souza (1996) analisou a influência da cidade de São Carlos no clima local por meio da comparação de dados contínuos de temperatura do ar entre maio de 1994 e abril de 1995, registrados em duas estações fixas - uma localizada na área urbana e outra localizada na área rural - equipadas com termohigrógrafo. A autora ( $o p$. cit.) analisou, ainda, a influência da geometria urbana nas condições de temperatura do ar na escala microclimática, a partir de dados procedentes de 22 pontos amostrais (sendo um fixo e 21 móveis), concentrados próximo a praça 15 de novembro, guardando a mesma cota altimétrica. Os dados foram registrados no período noturno, de 2 a 5 horas após o pôr-do-sol, em condições de céu claro e calmaria. Os resultados assinalaram que a influência da área urbana sobre as características térmicas é mais significativa no período noturno - do pôr-do-sol ao sol nascente -, com formação de ilha de calor urbana neste período, além de constatar que a geometria urbana não é o principal fator desse fenômeno térmico; não apontando outros fatores.

Fontes (1998) estudou os efeitos climáticos das áreas de fundo de vale no ambiente urbano de São Carlos a partir de dados procedentes de duas estações fixas equipadas com termohigrógrafos localizadas em área urbana e 14 pontos amostrais ao longo de uma rota de $8 \mathrm{~km}$, tomados por termômetro digital acoplados a um veículo. $\mathrm{O}$ registro de dados nos pontos móveis foram tomados às $9 \mathrm{~h}, 15 \mathrm{~h}, 19 \mathrm{~h}, 20 \mathrm{~h}$ e $21 \mathrm{~h}$, ao longo de uma semana no inverno e cinco dias no verão. Os resultados mostraram a formação de ilhas de calor, com maior intensidade no inverno, após o pôr-do-sol até o sol nascente, como já observado por Souza (1996).

Assim, a presente investigação procurou complementar estudos anteriores acerca do clima urbano de São Carlos (SOUZA, op. cit;; FONTES, op. cit.) por meio do estudo da configuração do campo térmico subsidiado pelo incremento no número de estações climáticas fixas em área urbana, com registro de dados contínuos totalizados por média em intervalos de 30 minutos, o que possibilitou a análise do comportamento das variáveis climáticas dentro de suas variações diurnas. Procurou, ainda, observar a 
intensidade da ilha de calor urbana em distintas condições atmosféricas impostas pelos diferentes tipos de tempo, com o aporte da abordagem dinâmica do clima. $O$ estudo foi limitado à análise das condições climáticas impostas pelos tipos de tempo habituais do período de verão, integrando-se a outra pesquisa em desenvolvimento com foco no período de inverno ${ }^{1}$.

Salienta-se, ainda, que a investigação em tela foi apoiada nas preposições teóricas e metodológicas do Sistema Clima Urbano, de Monteiro (1976), usadas em diversas pesquisas anteriores, as quais podemos citar: Sartori (1979), Sampaio (1981), Fonzar (1981), Lombardo (1985), Danni (1987), Mendonça (1994), Maitelli (1994), Brandão (1996), Sette (1996), Santos (1996), Pitton (1997), entre outros.

A motivação para a presente tese partiu da premissa de que o conhecimento do comportamento do campo térmico urbano nas suas dimensões espaços-temporais e dentro de suas variações diurnas e das condições impostas pelos diferentes tipos de tempo pode contribuir para diagnosticar alterações que ocorrem no sistema cidadeatmosfera e subsidiar ferramentas de planejamento urbano climaticamente adequadas.

A partir do exposto, a presente pesquisa teve por objetivo precípuo o estudo da configuração do campo térmico da cidade de São Carlos nas suas dimensões espaços-temporais, com vistas a conhecer a intensidade da ilha de calor urbana no período de verão, dentro de suas variações diurnas e das condições impostas pelos diferentes tipos de tempo.

Nesse contexto, destacou-se como objetivos específicos:

- Identificar e caracterizar os tipos de tempo habituais do período de verão, compreendidos em episódios representativos do fato climático para a região de São Carlos;

- Analisar a intensidade das diferenças de temperatura do ar entre diferentes áreas do tecido urbano da cidade de São Carlos dentro de suas variações diurnas e de suas variações impostas pelos diferentes tipos de tempo;

- Estudar o comportamento do campo térmico da cidade de São Carlos por meio da distribuição de temperatura do ar em diferentes regiões na malha urbana;

\footnotetext{
${ }^{1}$ A referida pesquisa trata-se da tese de doutoramento da física Ludimila Fabiana da Silva, em desenvolvimento até o momento de finalização desse trabalho, sob a orientação do prof. Francisco A. S. Vecchia, no Programa de Pós-Graduação em Ciências da Engenharia Ambiental, da Escola de Engenharia de São Carlos, Universidade de São Paulo, onde também foi defendida a presente tese.
} 
- Analisar a influência dos fatores geoambientais e geourbanos condicionantes da configuração do campo térmico da cidade em suas dimensões espaçostemporais e da formação de ilhas de calor no ambiente urbano no período de verão;

- Compreender os mecanismos - fatores geoambientais e geourbanos, além das condições atmosféricas impostas pelos diferentes tipos de tempo - que contribuem para a formação de ilhas de calor no ambiente urbano de São Carlos no período de verão.

A estrutura desta tese constitui-se de quatro etapas distintas, as quais foram traduzidas em capítulos. O primeiro capítulo consiste no embasamento conceitualteórico da presente investigação, o qual constou de revisão da literatura acerca da temática clima urbano. Nessa etapa foram descritos a evolução dos estudos afeitos ao tema no cenário mundial e a produção de pesquisas em clima urbano no cenário brasileiro. Foram abordados, ainda, os aspectos referentes à modificação das condições iniciais do clima, suas repercussões com o fenômeno de ilha de calor urbano e seus fatores condicionantes.

No segundo capítulo são apresentados a caracterização e os aspectos climáticos de São Carlos. Nessa etapa foram abordadas as características geoambientais da área de estudo, com destaque para a localização geográfica do município no topo das Cuestas Basálticas, e as características geourbanas, com enfoque no crescimento populacional e no processo de expansão da malha urbana. Foram abordados, ainda, os aspectos climáticos de São Carlos com a descrição da dinâmica atmosférica regional e local, além da característica e dos tipos de tempo habituais do período de verão.

O terceiro capítulo descreve os procedimentos metodológicos adotados na presente investigação, com a descrição das quatro estações automáticas instaladas na área urbana de São Carlos, cujo registros foram usados na análise do comportamento do campo térmico e na identificação de ilhas de calor na malha urbana. Essa etapa constou, ainda, na definição de um episódio climático representativo do período de verão.

Por fim, o quarto e último capítulo apresenta análise e discussão dos resultados obtidos. 



\section{Capítulo I}

\section{O AMBIENTE URBANO COMO MODIFICADOR DAS CONDIÇÕES INICIAIS DO CLIMA}

A camada da atmosfera dentro e imediatamente acima das áreas urbanas é profundamente modificada pelos elementos da cidade. Vários estudos comprovaram que a substituição da cobertura natural do solo pelo ambiente construído modifica as propriedades físicas e químicas do ar, assim como os processos aerodinâmicos, térmicos, hidrológicos e de intercâmbio de massas que ocorrem nessa camada da atmosfera próxima ao solo (CHANDLER, 1976; MONTEIRO, 1976; LOMBARDO, 1985; OKE, 1996). Assim, observa-se a modificação das condições iniciais do clima, resultando num clima peculiar denominado clima urbano.

Os primeiros estudos acerca da temática clima urbano foram realizados no início de século XIX, por meio das pesquisas de Luke Howard sobre o clima de Londres, cujos resultados foram publicados na obra "The Climate of London Deduced from Meteorological Observations Made in Metropolis and Various Places Around It”2, em 1833. Entretanto, Landsberg (2006) salientou que, após o trabalho pioneiro de Howard (op. cit.), os trabalhos referentes ao estudo de clima urbano limitaram-se, durante um século, a pontuar as diferenças existentes em estudos de caso.

Nesse sentido, Landsberg (1956) destacou como obras importantes nos estudos pioneiros sobre clima urbano, os trabalhos de Albert Kratzer e Brooks. Kratzer (1937), em sua tese de doutorado, em Munique, empreendeu uma abrangente revisão da literatura até então existente com 225 referências específicas e 25 estatísticas sobre este tipo de informação. Brooks (1952) elaborou uma bibliografia em clima urbano que contém 249 resumos e cobre a literatura entre 1833 e 1952.

A pesquisa de Howard foi consolidada com o trabalho de Chandler, "The Climate of London", realizado em 1965. Neste mesmo período, Emilien Renou

\footnotetext{
2 HOWARD, L. (1833). The Climate of London deduced from Meteorological Observations Made in the Metropolis and Various Places Around It. A. Arch., Cornhill, Longman and Co., London, 2ed.

${ }^{3}$ CHANDLER, T. J. (1965). The Climate of London. Hutchinson, London.
} 
desenvolveu pesquisas similares ${ }^{4}$ tendo como objeto de análise o clima da cidade de Paris, onde também foi comprovado o mesmo efeito de aquecimento do ar urbano, com evidencia no contraste térmico registrado entre a temperatura do ar na cidade $\mathrm{e}$ nos campos em seus arredores.

Após a Segunda Guerra Mundial observou-se aumento expressivo na quantidade de pesquisas acerca da temática clima urbano, especialmente nos Estados Unidos, Japão e Europa, devido à intensificação do processo de crescimento e expansão das áreas urbanas, bem como o crescimento da industrialização. As primeiras conferências com abordagem sobre o tema ocorreram no final da década de 1960. Nas décadas seguintes, notou-se o surgimento de pesquisas de referências sobre a modificação das condições iniciais do clima em áreas urbanas, dentre os quais podemos citar os trabalhos de Landsberg (1981), que desenvolveu compêndios sobre o clima urbano; e Oke (1978), que elaborou a compreensão do clima na camada limite urbana [Urban Boundary Layer - UBL].

No Brasil, os trabalhos pioneiros acerca da temática clima urbano foram realizados por Junot $\left(1940^{5}, 1943\right)$ e França $\left(1946^{6}\right)$, sobre o clima da cidade de São Paulo. Entretanto, outros trabalhos na área da climatologia urbana vieram a ser desenvolvidos na década de 1970, impulsionados pela queda da qualidade ambiental das grandes cidades brasileiras, evidenciados a partir da década anterior (MENDONÇA, 2003a). Nesse cenário, podemos citar os trabalhos de Gallego (1972), que procurou entender as relações entre dinâmica do tempo e poluição do ar na cidade de São Paulo e Rio de Janeiro; Pazera Júnior (1976a, 1976b); Conti (1979), que discutiu o crescimento urbano e as mudanças no clima local, entre outros. Contudo, a consolidação da climatologia urbana brasileira coincide com o trabalho de Monteiro (1975) intitulado "Teoria e clima urbano". Originalmente, o trabalho de Monteiro ( $o p$. cit.) foi apresentado como tese ao concurso à livre-docência junto ao Departamento de Geografia da Faculdade de Filosofia, Letras e Ciências Humanas da Universidade de São Paulo, e publicado no ano seguinte sob a forma de livro.

Também foi na década de 1970 que a pesquisa em climatologia urbana, no Brasil, registrou os primeiros estudos de caso. Nesse primeiro momento de

\footnotetext{
${ }^{4}$ RENOU, Emilie (1862). Différences de temperature entre Paris et Choisy-le-Roi. Annuaire Soc. Met. France, pp.105.

RENOU, Emilie (1868). Différences de temperature entre la ville et la campagne. Annuaire Soc. Met. France. pp.83-97.

${ }^{5}$ JUNOT, L. R. (1940). Estudo da temperatura da cidade de São Paulo. In: Congresso Brasileiro e Geografia, 9. Anais... Florianópolis. v.2. p. 460-488.

${ }^{6}$ FRANÇA, A. (1946). Estudo sobre o clima da bacia de S. Paulo. Boletim LXX da Faculdade de Filosofia, Letras e Ciências Humanas. Universidade de São Paulo. n.1, p.59.
} 
investigação, a cidade de São Paulo aparece como sendo aquela sobre a qual os estudiosos dedicaram-se de maneira mais expressiva, destacando-se, nesse contexto, os trabalhos de Monteiro (1980), Paschoal (1981), Titarelli (1982), Lombardo (1984), Sobral (1988), entre outros. Mendonça (2003a) atribuiu esse fato a dois motivos: (a) por caracterizar-se, já naquela época, como a maior aglomeração urbana e num dos maiores degradados ambientes urbanos do Brasil; e (b) por possui maior concentração de instituições de ensino e de pesquisa voltada à temática no país. De fato, grande parte da produção bibliográfica acerca de clima urbano no Brasil nas décadas de 1970 e de 1980 remete-se à Faculdade de Filosofia, Letras e Ciências Humanas da Universidade de São Paulo, sob a orientação dos professores Carlos Augusto de Figueiredo Monteiro e José Roberto Tarifa.

Apesar das pesquisas desenvolvidas nesse período ser predominantemente sobre o clima da cidade de São Paulo, outras cidades brasileiras tiveram seu clima urbano analisado. Nesse sentido, destacam-se os trabalhos de Tavares (1975), sobre o clima urbano de Campinas-SP; Sampaio (1981), que relacionou o uso do solo e elevação de temperatura do ar no ambiente urbano de Salvador-BA; Dani (1987), que observou a formação de ilha de calor em Porto Alegre-RS, entre outros.

Assis (1990) destacou estudo realizado no Rio de Janeiro pela Fundação Estadual de Engenharia do Meio Ambiente, em 1983, no qual revelou a formação de ilhas de calor nas áreas densamente edificadas da cidade, como no centro e alguns locais da Tijuca, onde foram detectadas diferenças térmicas superiores a $4^{\circ} \mathrm{C}$ entre essas áreas e as áreas vizinhas, com menor densidade de ocupação. O fenômeno foi atribuído ao excesso de área construída e à concentração de poluentes provocada pelas correntes de ar locais e pela situação favorável da topografia.

O clima urbano em cidades de porte médio foi estudado por Tarifa (1977), que estabeleceu correlação entre tamanho e temperatura da cidade de São José dos Campos-SP, e Monteiro \& Tarifa (1977), que analisou as características do clima na cidade de Marabá-PA com vistas a subsidiar o planejamento urbano. Os efeitos da ilha de calor em cidades de porte médio foram abordados por Sartori (1979), cidade de Santa Maria, e Fonzar (1981), cidade de Presidente Prudente, ao tempo que Camargo \& Tavares (1985) analisaram a influência da cidade no comportamento higrotérmico, em Rio Claro. YAMASHITA, IMAMURA, \& MONTEIRO (1988) realizaram medidas de temperatura e umidade em cidades do Nordeste brasileiro - Patos e Campina Grande (PB) - usando transecto móvel com sensores acoplados a um automóvel. Os resultados mostraram $2^{\circ} \mathrm{C}$ para ilha de calor em Patos e valores inferiores a $1^{\circ} \mathrm{C}$ para Campina Grande. 
Em 1984, a Organização Meteorológica Mundial - OMM, órgão das Nações Unidas, organizou uma conferência técnica, no México, cuja organização científica do encontro ficou sob a responsabilidade de Tim Oke, para discussões sobre Climatologia Urbana e suas aplicações, com enfoque especial para as áreas tropicais. Neste encontro, Monteiro (1986) apresentou avaliação dos estudos de clima urbano realizados no Brasil, no período de 1974-84. Essa avaliação pautou-se em alguns blocos de diagramas de metrópoles brasileiras, como São Paulo, Rio de Janeiro, Salvador e Porto Alegre, além de alguns perfis de cidades médias, como Santa MariaRS, São José dos Campos-SP, Presidente Prudente-SP e Marabá-PA, provenientes dos trabalhos anteriormente citados.

Dos trabalhos pioneiros para os dias atuais, observou-se grande avanço nas pesquisas afeitas ao clima nas cidades brasileiras.

\section{O CLIMA URBANO}

O clima urbano é uma modificação substancial de um clima local, resultado das condições particulares do meio ambiente urbano, seja pela sua rugosidade, uso e ocupação do solo, orientação, permeabilidade e propriedades dos materiais constituintes, entre outros fatores (OKE, 1996). Monteiro (1976) definiu o clima urbano como um sistema que abrange o clima de um dado espaço terrestre e sua urbanização. É um mesoclima que está incluído no macroclima, o qual sofre, na proximidade do solo, influências microclimáticas derivadas dos espaços urbanos (LOMBARDO, 1985).

Nesse contexto, Monteiro (1990) colocou que o clima da cidade é produzido a partir de um fenômeno de transformação de energia num jogo integrado entre o ar atmosférico e o ambiente urbano edificado pelo homem. Nessa interação, o ar atmosférico - resultante dos sistemas atmosféricos regionais - e o ambiente edificado se relacionam, principalmente, por meio das propriedades físicas dos materiais que compõem as superfícies do tecido urbano - albedo, absorção e a transmissão de calor. A superfície da cidade construída de área edificada influi de maneira tridimensional na interação que existe entre a estrutura urbana e a atmosfera (LOMBARDO, 1985). Assim, observa-se que o clima urbano é um sistema complexo, adaptativo e aberto que, ao receber energia do ambiente maior no qual se insere, a transforma substancialmente a ponto de gerar uma produção exportadora ao ambiente (TAVARES \& PROCHNOW, 1997; MONTEIRO \& MENDONÇA, 2003), resultando num balanço energético diferenciado. 
De acordo com Lopes (2003), Sundborg ${ }^{7}$, em Uppsala, na Suécia, foi o primeiro autor que levou o conceito de balanço energético para a climatologia urbana, em 1951. Entretanto, Oke (1988) destacou que as primeiras observações e modelos numéricos de balanço energético urbano surgiram na década de 1970, ainda muito simples, porém intuitivos.

O balanço de energia para um determinado sistema está baseado na primeira lei da Termodinâmica - princípio de conservação - em que a energia não pode ser criada e nem destruída somente convertida para outra forma:

\section{Entrada de energia = saída de energia + energia armazenada}

No ambiente urbano, o balanço energético é satisfatoriamente representado por fluxos de energia através do volume solo-construções-ar, até uma altura onde as trocas verticais de calor são desprezíveis para o período de análise (KALANDA \& SPITTLEHOUSE, 1980; BARBIRATO; SOUZA; TORRES, 2007). A maioria dos modelos desenvolvidos, salvo algumas simplificações, considera os seguintes componentes na equação do balanço de energia ao topo da camada intra-urbana:

$$
Q^{*}+Q_{F}=\Delta Q_{S}+\Delta Q_{A}+Q_{H}+Q_{E}
$$

Onde:

$Q^{*}=\quad$ fluxo de radiação líquida, em função do albedo, energia solar difusa e direta, radiação infravermelha emitida pelo topo da camada intraurbana e densidade de fluxo infravermelho da atmosfera;

$\mathbf{Q}_{\mathbf{F}}=$ fluxo de calor antropogênico (combustão, condicionamento do ar, etc.);

$\Delta Q_{S}=$ densidade de fluxo de armazenamento de energia na camada intraurbana e solo;

$\Delta Q_{A}=$ advecção líquida;

$Q_{H}=$ fluxo de calor turbulento sensível;

$Q_{E}=$ fluxo de calor turbulento latente.

Barbirato; Souza \& Torres (2007) destacaram que a radiação solar é o componente de valor mais elevado no balanço de energia. As superfícies ganham calor por radiação solar durante o dia e perdem por ondas longas, num processo contínuo, dia e noite. Parte desta radiação é refletida, conforme seu albedo, e outra é absorvida. Parte da energia proveniente da radiação solar absorvida pela superfície é

7 Lopes (2003) não citou a obra na qual Sundborg, em 1951, leva o conceito de balanço energético para a Climatologia. 
usada como calor latente na evaporação da água nela contida, reduzindo a elevação da sua temperatura, ao tempo que a outra parte da energia é conduzida às camadas mais internas da superfície.

Em áreas urbanas, a presença de superfícies impermeáveis acelera o escoamento da água que estaria disponível para evaporação e a radiação solar absorvida é rapidamente convertida em calor, elevando sua temperatura, e, conseqüentemente, a de seu entorno. Além disso, as edificações propiciam o armazenamento de radiação de ondas curtas pela incidência solar direta e por meio de múltiplas reflexões sofridas pelos raios solares ao encontrarem as superfícies das edificações, o que favorece o aumento de energia solar absorvida.

As edificações também constituem um obstáculo ao resfriamento urbano, uma vez que dificultam a perda de radiação de ondas longas para o espaço. Sobre esse aspecto, Sampaio (1981, p.23) colocou que "(...) os mecanismos de absorção e trocas laterais de calor nas áreas centrais urbanas, pelas massas de edificações, representam um considerável ganho de energia térmica que repercute sensivelmente na energia líquida, como insumo no "quantum" local do balanço térmico". Dessa forma, observa-se que a compressão do balanço de energia da superfície urbana permite melhor conhecimento do clima urbano e de seus componentes, dentre eles o campo térmico urbano.

O campo térmico no ambiente urbano é produto do balanço energético resultante do sistema cidade-atmosfera. Nesse contexto, Monteiro (1990) ressaltou que, ao penetrar na cidade para investigar-lhes o clima, o procedimento preliminar básico dirige-se à análise do campo térmico urbano, a partir do qual, todo um jogo de correlações e de interações se produz na geração das características climáticas da cidade. O estudo do campo térmico urbano também foi destacado por Pitton (1997) ao analisar as cidades como indicadoras de alterações térmicas em escala local.

O campo térmico urbano configura-se, portanto, por apresentar mais aquecido do que o ambiente rural circunvizinho, devido, sobretudo, à densidade de massa edificada e às propriedades físicas dos materiais de construção do ambiente urbano, apresentando maior capacidade de armazenamento de calor. Além disso, a geometria dos prédios e a excessiva ocupação do solo contribuem para a estagnação e a canalização do ar, com a formação de uma superfície de grande aspereza. Esses fatores contribuem para a alteração do balanço de energia no ambiente urbano e, conseqüentemente, para a conformação de seu campo térmico, o qual tende a apresentar bolsões de ar mais aquecido sobre as áreas mais adensadas - fenômeno denominado ilhas de calor (LOMBARDO, 1985). 


\subsection{Ilha de calor urbano}

A ilha de calor urbano é o exemplo mais evidente de alteração climática provocada pelo processo de urbanização (OKE, 1995). Arnfield (2003) publicou estudo revendo os artigos mais importantes das duas últimas décadas sobre climatologia urbana, em língua inglesa. Nessa revisão, o autor (op. cit.) apontou variados exemplos de estudos em climas equatoriais, tropicais, subtropicais, desérticos, de montanha, mediterrâneos e cidades de altas latitudes. Em todas elas, foi apontada a existência de ilhas de calor, embora com características distintas, devido às diferenças climáticas e às condições locais como posição geográfica, proximidade com o oceano ou outra grande massa d'água, tamanho da cidade, entre outros.

No Brasil, diversos estudos constaram a formação de ilha de calor urbana em diferentes cidades brasileiras. Entretanto, Assis e Pereira (2005), ao realizar levantamento da produção brasileira sobre clima urbano, constataram que a variável climática mais estudada é a temperatura do ar, em sua distribuição nas escalas horizontal e temporal, porém os fatos da ilha de calor urbano são abordados em um a cada dez trabalhos publicados.

Considerando a magnitude do fenômeno de geração de ilhas de calor urbano, muitos são os mecanismos que contribuem para a sua formação e muitos são os fatores e sistemas que agravam a sua intensidade, desde a sua localização geográfica até as condições climatológicas do dia. Há também fatores relacionados às características específicas da cidade, como tamanho, densidade populacional, além das variações diurnas e sazonais (LOMBARDO, 1985). Assim, Sampaio (1981) colocou que a ilha de calor funciona como uma variável dependente, explicada por dois grupos de variáveis: (a) as condicionantes do meio físico e seus atributos geoecológicos; e (b) as condicionantes derivadas das ações antrópicas sobre o ambiente urbano, em termos de uso e ocupação do solo.

Landsberg (1974) afirmou que, dentre os vários fatores que geram a ilha de calor, o mais importante parece ser a mudança no balanço de energia - o qual tem repercussão em vários componentes. Nesse sentido, observa-se que o fluxo de calor estocado pelo tecido urbano $\left(Q_{S}\right)$, juntamente com o fluxo de calor antropogênico $\left(Q_{F}\right)$, são a principal causa da formação de ilhas de calor. Essa afirmação baseia-se na premissa de que a condutividade térmica e a capacidade de armazenar calor dos materiais urbanos são maiores do que as dos solos rurais (MAITELLI, 1994). KERSCHGENS \& KRAUS (1990) estudaram o armazenamento de calor na escala local e sua interação com as correntes advectivas na mesoescala, mostrando a influência da estrutura urbana neste processo. 
Nos grandes centros urbanos, a ilha de calor também está associada aos contrastes climáticos que ocorrem na malha urbana. No inverno, ressalta-se a associação entre a ilha de calor e altos índices de poluição, assim como abaixamento da umidade relativa do ar, o que se traduz e um estado de desconforto térmico urbano. No verão, a ilha de calor está associada às perturbações de instabilidade localizadas na mancha urbana, tendo como efeito a intensificação das precipitações (ASSIS, 1990; DINES, 1991).

A ilha de calor urbana é, pois, uma anomalia térmica que tem sido observada em todos os tipos de assentamentos humanos pesquisados, extensos ou não. Vários estudos têm mostrado que suas características se relacionam com a natureza intrínseca da cidade e com as influências externas de mais larga escala (o clima regional, condições predominantes e tempo atmosférico e variações sazonais. Quanto aos atributos urbanos, Oke (1982) mencionou as variáveis do balanço energético que favorecem a formação da ilha de calor urbana. Salienta-se que as variáveis não foram ordenadas por ordem de importância.

Quadro 1: Causas da ilha de calor urbana, não ordenadas por ordem de importância.

\begin{tabular}{|l|l|}
\hline \multicolumn{1}{|c|}{$\begin{array}{l}\text { Variáveis alteradas do balanço energético } \\
\text { que conduzem à anomalias térmica }\end{array}$} & $\begin{array}{c}\text { Características da urbanização que motivam } \\
\text { as mudanças no balanço energético }\end{array}$ \\
\hline A. CAMADA DE COBERTURA URBANA \\
\hline $\begin{array}{l}\text { 1. Aumento da absorção da radiação de onda } \\
\text { curta }\end{array}$ & $\begin{array}{l}\text { Geometria de "canyon" - aumento da área de } \\
\text { superfície exposta e de reflexão múltipla. }\end{array}$ \\
\hline $\begin{array}{l}\text { 2. Aumento da radiação de onda longa vinda } \\
\text { do céu. }\end{array}$ & Poluição do ar - maior absorção e re-emissão. \\
\hline $\begin{array}{l}\text { 3. Diminuição da perda de radiação de onda } \\
\text { longa. }\end{array}$ & $\begin{array}{l}\text { Geometria de "canyon" - reduação do "fator } \\
\text { de céu visível" }\end{array}$ \\
\hline 4. Fonte de calor antropogênico & Perdas de calor dos edifícios e tráfico urbano. \\
\hline $\begin{array}{l}\text { 5. Aumento do armazenamento de calor } \\
\text { sensível }\end{array}$ & $\begin{array}{l}\text { Materiais de construção - aumento da inércia } \\
\text { térmica }\end{array}$ \\
\hline $\begin{array}{l}\text { 6. Diminuição da evapotranspiração } \\
\text { 7. Diminuição do calor total transportado pelo } \\
\text { fluxo de ar turbulento }\end{array}$ & $\begin{array}{l}\text { Materiais de construção - aumento da } \\
\text { impermeabilidade do solo }\end{array}$ \\
\hline B. CAMADA LIMITE URBANA & $\begin{array}{l}\text { Geometria de "canyon" - redução da } \\
\text { velocidade do vento }\end{array}$ \\
\hline $\begin{array}{l}\text { 1. Aumento da absorção da radiação de onda } \\
\text { curta }\end{array}$ & $\begin{array}{l}\text { Poluição do ar - aumento da absorção pelos } \\
\text { aerossóis }\end{array}$ \\
\hline 2. Fonte de calor antropogênico & Perdas de calor pelas chaminés e tráfego \\
\hline $\begin{array}{l}\text { 3. Aumento da "entrada" de calor sensível } \\
\text { vindo de baixo }\end{array}$ & $\begin{array}{l}\text { llha de calor ao nível da cobertura urbana - } \\
\text { aumento do fluxo de calor da camada e } \\
\text { telhados }\end{array}$ \\
\hline $\begin{array}{l}\text { 4. Aumento da "entrada" de calor sensivel } \\
\text { vindo de cima }\end{array}$ & $\begin{array}{l}\text { llha de calor, rugosidade - aumento da } \\
\text { "entrada" turbulenta }\end{array}$ \\
\hline
\end{tabular}

Fonte: Adaptado de OKE, 1982. 
Quanto às influências externas de mais larga escala, Jauregui (1973) enfatizou a importância das condições sinóticas do clima local na formação e desenvolvimento de ilhas de calor. Sob este aspecto, Lombardo (1985) observou, em seu estudo sobre o clima da cidade de São Paulo, que a dinâmica da ilha de calor conteve, em seu bojo, o comportamento da atmosfera, na evolução dos estados de tempo. Nesse sentido, a intensidade da ilha de calor urbano foi menor nos períodos com a participação dos avanços de fluxos de ar frio da massa Polar Atlântica, com queda de temperatura e ocorrência de precipitação. A autora ( $o p$. cit) enfatizou, ainda, que a maior expressão do fenômeno, em área e no gradiente de temperatura, ocorreu em dias de céu claro, com calmaria e subsidência.

Ainda com relação à intensidade e variabilidade da ilha de calor urbano, diversos estudos apontam seu desenvolvimento em noites claras e calmas, entre 2 a 5 horas após o pôr-do-sol, quando o resfriamento das áreas periféricas e rurais é maior do que aquele ocorrido em áreas urbanas. Souza (1996) ressaltou que após atingir o seu máximo (entre 2 a 5 horas após o pôr-do-sol), a intensidade da ilha de calor decai, sendo eliminada quando ocorre a temperatura máxima, no dia seguinte. Quanto à intensidade e variabilidade sazonal do fenômeno, Lombardo (1985) e Oliveira (1988) enfatizaram que a maior expressão da ilha de calor ocorre no inverno e sua menor intensidade é observada no verão.

\subsection{Fatores condicionantes do clima urbano}

Os fatores condicionantes atribuem características diferenciadas daquela do sítio original que repercutem na conformação de um campo térmico e de um campo de ventos oriundos de um "ar comprometido" com os atributos urbanos, como definiu Monteiro (1990). O "ar comprometido" é produto de um balanço energético peculiar à cidade.

Landsberg $(1956,2006)$ citou três causas básicas das modificações nas condições iniciais do clima que podem ser provocadas pela urbanização: (a) alteração da superfície e o aumento da rugosidade aerodinâmica; (b) produção de calor pela própria cidade, indo desde aquele proveniente do metabolismo da massa de seres humanos e animais ao calor liberado por fornos das residências e indústrias, além do calor produzido por milhões de motores de combustão interna provenientes dos veículos motorizados; e (c) a alteração da composição da atmosfera, pela adição de material sólido inerte, gases e substâncias químicas ativas.

A alteração da superfície e o aumento da rugosidade aerodinâmica citado por Landsberg (op. cit.) estão intimamente relacionados com a ocupação do solo pela 
cidade. Nesse cenário, Oliveira (1988) destacou sete fatores condicionantes do clima urbano provenientes dessa ocupação: (a) rugosidade e porosidade; (b) densidade de construção; (c) ocupação do solo; (d) tamanho, no qual se devem considerar as dimensões horizontais e verticais da cidade; (e) orientação da malha urbana; (f) permeabilidade do solo; e $(\mathrm{g})$ propriedades termodinâmicas dos materiais constituintes das superfícies urbanas. Assis (1990) observou que a "geometria da malha urbana"deve ser acrescida à lista elaborada por Oliveira (op. cit.) como importante fator morfológico que condiciona o clima local.

Os efeitos da rugosidade e da porosidade da superfície urbana são notadamente significativos sobre o campo dos ventos na cidade. A rugosidade corresponde à maior ou à menor friç̧ão entre a superfície urbana e os ventos que a atravessam, ao tempo que a porosidade pode ser definida como a maior ou menor permeabilidade que a estrutura urbana favorece aos ventos (OLIVEIRA, 1988; BARBIRATO, SOUZA, TORRES, 2007). Nesse sentido, observa-se que, sendo a superfície urbana mais rugosa do que a superfície do campo a sua volta, gera maior atrito com as massas de ar em movimento. Esse fato propicia a redução da velocidade dos ventos no interior da malha urbana, assim como alterações no deslocamento dos ventos, que passam a turbilhonar.

Do modo análogo, a diminuição da porosidade da malha urbana, expressa pela redução de índices que definem afastamentos mínimos entre o edifício e o limite do lote, além do aumento do gabarito das edificações, reduz a velocidade do ar no interior da malha urbana (BARBIRATO, SOUZA, TORRES, 2007). Cabe ressaltar que a direção e a velocidade dos ar na malha urbana são rigorosamente controladas pela forma e a disposição dos edifícios, padrão de arruamento e espaços abertos, além das condições topográficas do sítio urbano (DINES, 1991).

No que concerne à densidade de construção, sua maior influência são notadamente significativas no campo térmico urbano e na formação de ilhas de calor. Nesse sentido, vários estudos mostraram que o centro da ilha de calor numa cidade está freqüentemente localizado sobre a área de maior densidade de construção (CHANDLER, 1965; LOWRY, 1990; LOMBARDO, 1984; DINES, 1991).

Quanto à ocupação do solo, Oliveira (1988) destacou que os resultados obtidos em diversos estudos apontaram que existe estreita correlação entre a ocupação do solo e a distribuição das temperaturas dentro das estruturas urbanas. Barbirato, Souza \& Torres (2007) destacaram que os padrões de ocupação com maior densidade tendem a possuir as maiores médias de temperatura, enquanto que os padrões de ocupação com menores taxas tendem a possuir menores médias. 
Concernente ao tamanho da estrutura urbana, a relação entre esse fator e a magnitude da ilha de calor parece ser variável. Oliveira (1988), analisando vários autores, conclui que a relação entre o tamanho da cidade e a diferença de temperatura rural-urbana não é linear, embora seja evidente que quanto maior a estrutura urbana, maior será a alteração da superfície e a quantidade de fontes produtoras de calor e de poluentes.

A orientação refere-se ao posicionamento da malha urbana em relação à influência da insolação e da incidência dos ventos ou modificações na morfologia do solo e da paisagem e barreiras edificadas. Dines (1991) apontou que a orientação da manha urbana influencia diretamente o microclima urbano, determinando maior ou menor exposição das estruturas urbanas àqueles elementos.

A permeabilidade está relacionada com a quantidade de superfície de solo urbano recoberto por edificações ou pavimentadas e a quantidade de solo nú compactado. Os efeitos nocivos do excesso de impermeabilização do solo são apontados por vários autores (CHANDLER, 1967; LANDSBERG, 1981; LOMBARDO, 1984; entre outros). Nesse sentido, BARBIRATO, SOUZA \& TORRES (2007) destacaram que a baixa permeabilidade provoca a redução da umidade do ar e da vaporação na área urbana, decorrente da pouca absorção das águas pluviais pela superfície do solo; maior quantidade de calor acumulado e altas temperaturas na estrutura urbana, além de tendência cíclica de inundações.

As propriedades termodinâmicas dos materiais estão ligadas às propriedades físicas como albedo, absortância à radiação solar, emissividade, inércia térmica e índices de impermeabilidade dos materiais da massa edificada (DINES, 1991; BARBIRATO; SOUZA; TORRES, 2007). Dines (1991) destacou que a relação entre as altas taxas de ocupação e uso do solo, o alto índice de impermeabilização e a natureza essencialmente "termófila" dos materiais utilizados no ambiente construído são decisivas no aumento das temperaturas.

Além dos fatores urbanos, sabe-se que conformação física do sítio sobre o qual se assenta a cidade pode exercer importante influência sobre as condições atmosféricas da cidade, determinando sua exposição aos ventos ou à insolação. Nesse sentido, Barbirato, Souza \& Torres (2007) comentaram que alguns estudos apontam que as características da morfologia do solo e da paisagem, como a convexidade ou concavidade do sítio, são fatores que exercem significativa influência na conformação do clima urbano. Sobre essa abordagem, Sampaio (1981) observou que a posição privilegiada do sítio no qual se assenta o bairro de São Pedro, em 
Salvador-BA, facilita sua exposição à ventilação predominante, amenizando as possibilidades de armazenar calor nas massas edificadas.

Observou-se, nesse sentido, que o estudo do clima de uma cidade, comprometido com o processo de urbanização e com a qualidade climática, requer, inicialmente, o conhecimento sobre o sítio onde a cidade está assentada, pois além de ser o meio natural que serve de suporte para a cidade, interage com a mesma, configurando diferentes comportamentos na atmosfera (FONTES, 1998). Dessa forma, a caracterização do ecossistema de estudo da presente pesquisa foi abordado no capítulo seguinte. 


\section{CARACTERIZAÇÃO E ASPECTOS CLIMÁTICOS DO ECOSSISTEMA DE ESTUDO: A CIDADE DE SÃO CARLOS}

O município de São Carlos possui extensão territorial de $1.140 \mathrm{~km}^{2}$ e está localizado na região centro-norte do estado de São Paulo, entre as coordenadas

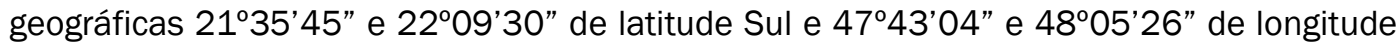
Oeste, na região Sudeste do Brasil. Dista aproximadamente $240 \mathrm{~km}$ da capital do estado e limita-se ao norte com os municípios de Rincão, Luis Antônio e Santa Lúcia; ao sul com Ribeirão Bonito, Brotas e Itirapina; a oeste com Ibaté, Araraquara e Américo Brasiliense; e a leste com Descalvado e Analândia.

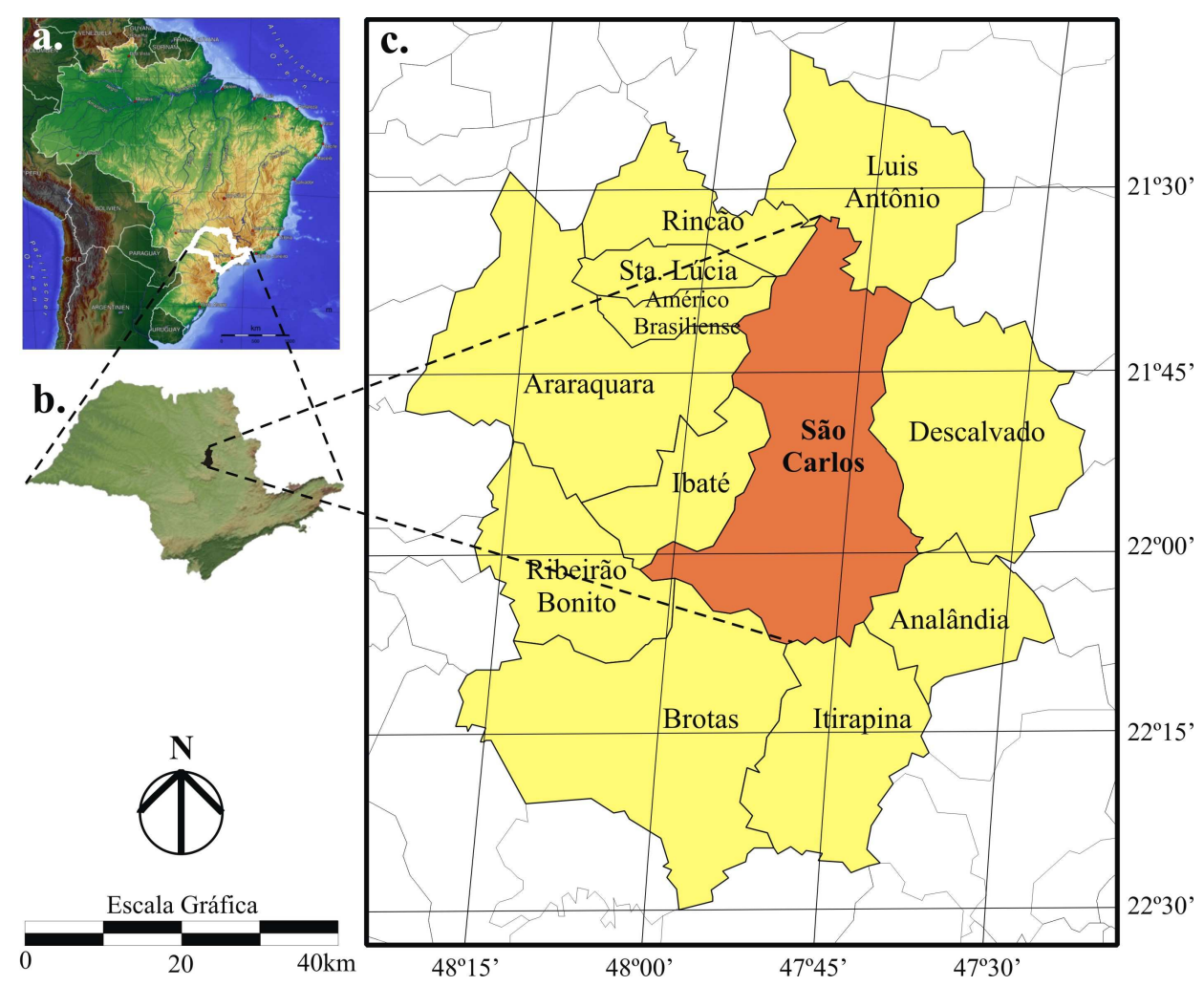

Figura 1: (a) Localização do estado de São Paulo no Brasil, (b) localização do município de São Carlos no estado de São Paulo e (c) municípios limítrofes e localização geográfica do município de São Carlos. 


\section{CARACTERÍSTICAS GEOAMBIENTAIS}

\section{- Geomorfologia}

O município de São Carlos está assentado na borda oeste das Cuestas Basálticas, próximo ao Planalto Ocidental. A província geomorfológica das Cuestas Basálticas localiza-se entre as províncias do Planalto Ocidental e a Depressão Periférica (ALMEIDA, 1964), segundo a subdivisão geomorfológica do estado de São Paulo, conforme indica a Figura 2 (IPT, 1981; ROSS \& MOROZ, 1997).

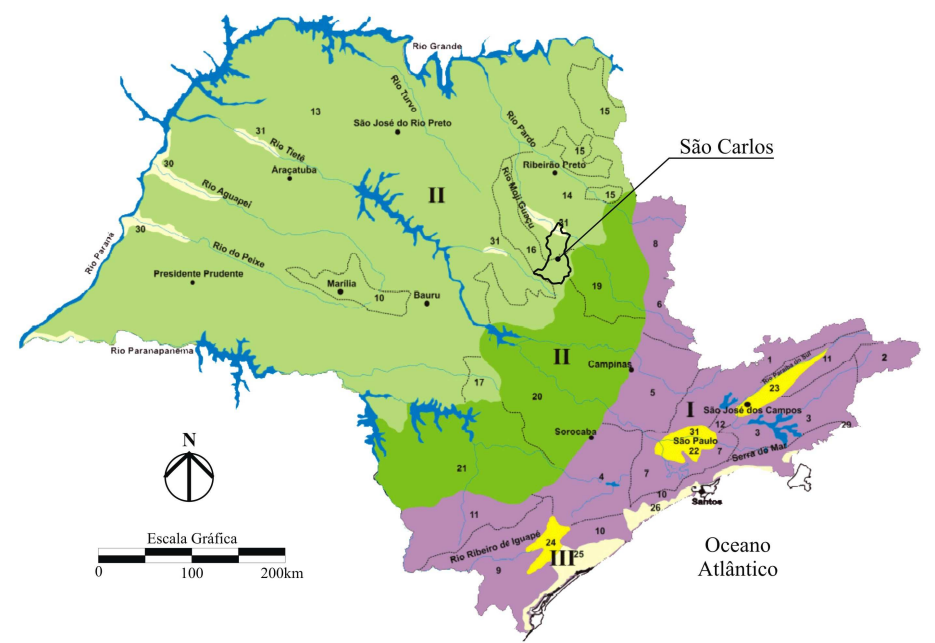

\section{I - Cinturão Orogênico do Atlântico}

PLANALTO ATLÂNTICO

1 - Planalto e Serra da Mantiqueira

2 - Planalto e Serra da Bocaina

3 - Planalto da Paraitinga/Paraibuna

4 - Planalto de Ibiúna/São Roque

5 - Planalto de Jundiaí

6 - Planalto de Serra Negra/Lindóia
7 - Planalto Paulistano/Alto Tietê

8 - Planalto do Alto Rio Grande

9 - Planalto do Ribeira/Turvo

10 - Escarpa/Serra do Mar e Morros

Litorâneos

11 - Planalto de Guapiara

12 - Planalto do Médio Vale do Paraíba

\section{II- Bacia Sedimentar do Paraná}

PLANALTO OCIDENTAL PAULISTA

13- Planalto Centro Ocidental

14 - Planalto em Patamares

Estruturais de Ribeirão Preto

15 - Planaltos Residuais de

Batatais/Franca

16 - Planalto Residual de S. Carlos

17 - Planalto Residual de Botucatu

18 - Planalto Residual de Marília
DEPRESSÃO PERIFÉRICA PAULISTA

19 - Depressão Mogi-Guaçú

20 - Depressão Médio Tietê

21 - Depressão Paranapanema

III - Bacias Sedimentares Cenozóicas

22 - Planalto de São Paulo

23 - Depressão do Médio Paraíba

24 - Depressão do Baixo Ribeira
PLANÍCIES LITORÂNEAS E FLUVIAIS

25 - Iguape/Cananéia 29 - Litoral Norte

26 - Praia

Grande/lperoibe

27 - Santista

28 - Bertioga

30 - Rio Paraná

31 - Diversos

Figura 2: Mapa simplificado de províncias geomorfológicas do estado de São Paulo, com localização da área de estudo.

Fonte: Adaptado de: ALMEIDA, 1964. 
As Cuestas Basálticas constituem uma das formas mais marcantes do relevo paulista. Seu relevo dissimétrico é constituído principalmente por camadas de rochas areníticas e basálticas. Assim, a variedade de formas de relevo presentes nessa província geomorfológica foi condicionada pela atuação diferenciada do processo de erosão sobre as camadas geológicas de rochas vulcânicas - mais resistentes -, e sobre camadas geológicas sedimentares - menos resistentes (SÉ, 1992).

As Cuestas são caracterizadas por exibir escarpas com cortes abruptos e perfil com declive íngreme, em seu fronte - no limite com a Depressão Periférica -, seguido por plataformas que apresentam escarpas menores, dando um caráter misto de colinas e escarpas ao relevo geral em seu interior, culminando com uma sucessão de grandes plataformas estruturais de relevo suavizado, em seu reverso - no limite com o Planalto Ocidental.

Os reversos das Cuestas Basálticas, por sua vez, apresentam variações fisionômicas regionais peculiares. Ross \& Moroz (1997) delimitaram essas variações em unidades geomorfológicas distintas, denominando-as Planaltos Residuais.

Nesse sentido, a unidade geomorfológica do Planalto Residual de São Carlos apresenta relevo talhado nas camadas sedimentares que compõem a unidade morfoestrutural Bacia Sedimentar do Paraná, com altitude que variam entre 600 a 900 $\mathrm{m}$, apresentando vertentes de baixa declividade, entre 2 e $20 \%$, atingindo $30 \%$ apenas nas porções de relevo mais dissecadas. As formas de relevo predominantes são denudacionais, cujo modelado apresenta-se na forma de colinas de topo convexos e tabulares. Os vales apresentam entalhamentos que variam entre 20 a $80 \mathrm{~m}$, com dimensão interfluvial média varia de 250 a 3750 m e densidade de drenagem de média a alta.

Assim, o relevo do município de São Carlos, como toda região circunvizinha assentada na unidade geomorfológica do Planalto Residual de São Carlos, tem aspecto bastante movimentado, constituindo de mesas e morros isolados, resultado de intensa erosão provocada pelos rios que, partindo de zonas elevadas, entalharam profundamente o planalto. A altimetria do município apresenta uma variação de 480 metros. As menores cotas - $520 \mathrm{~m}$ - estão localizadas na área de alagamento próxima ao Rio Mogi-Guaçú, ao Norte. As cotas mais altas atingem 1.000 m, na porção Sudeste do Município, conforme mostra a Figura 3c (PMSC, 2004). No sítio urbano, as menores cotas altimétricas são em torno de $775 \mathrm{~m}$, localizadas em vales a oeste da cidade; os pontos mais elevados estão situados a leste, em planalto que ultrapassa os $910 \mathrm{~m}$ de altitude (BORTOLUCCI, 1983). 
a)

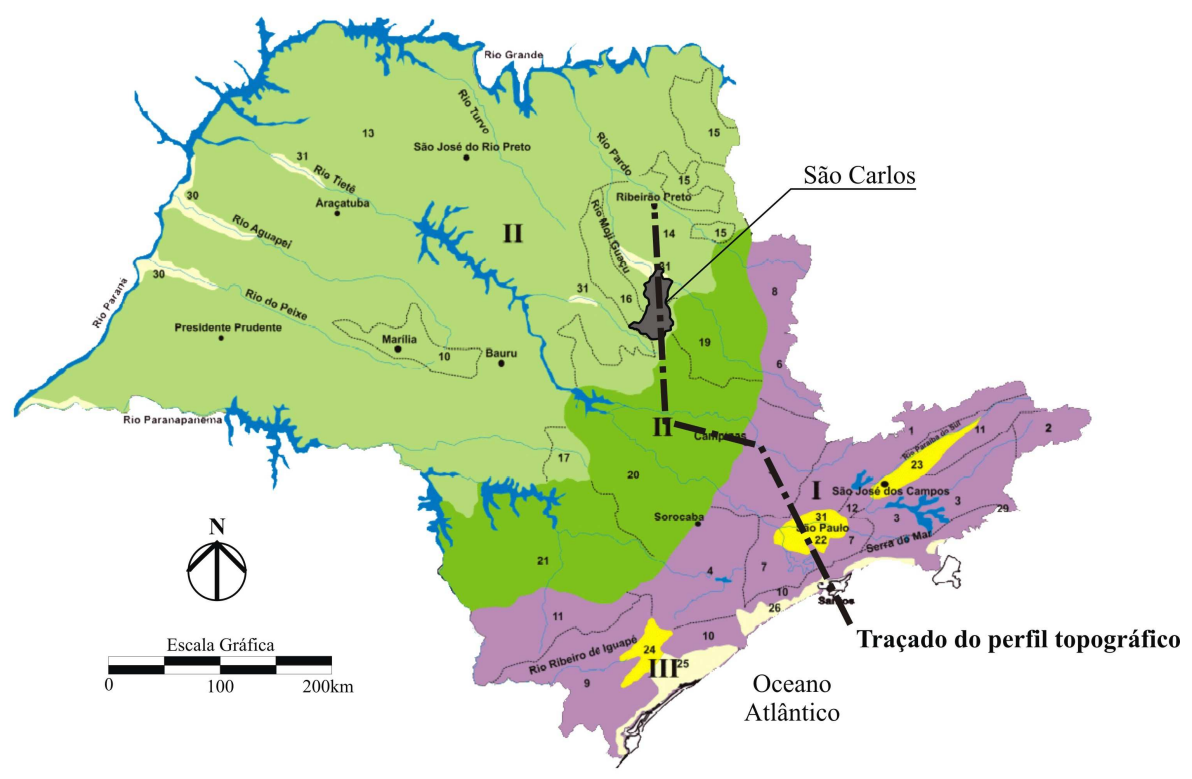

b)

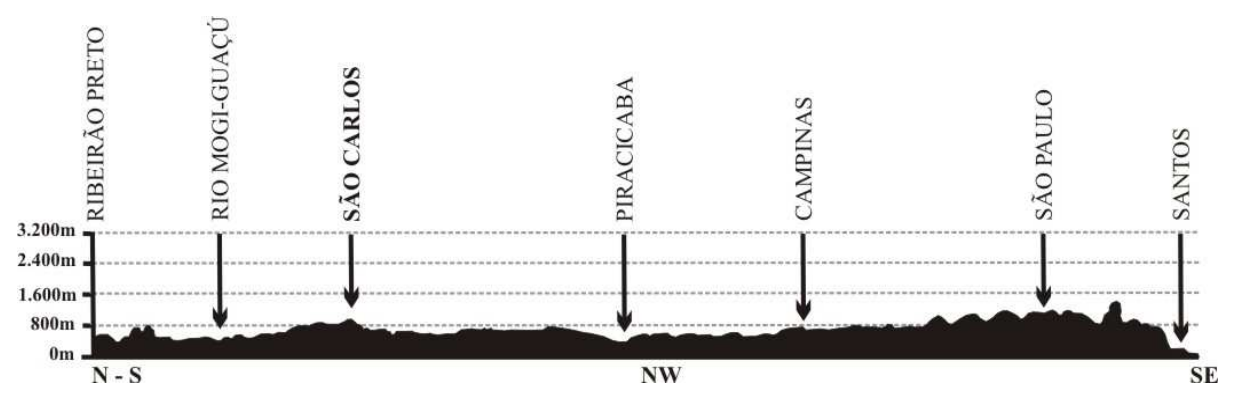

c)

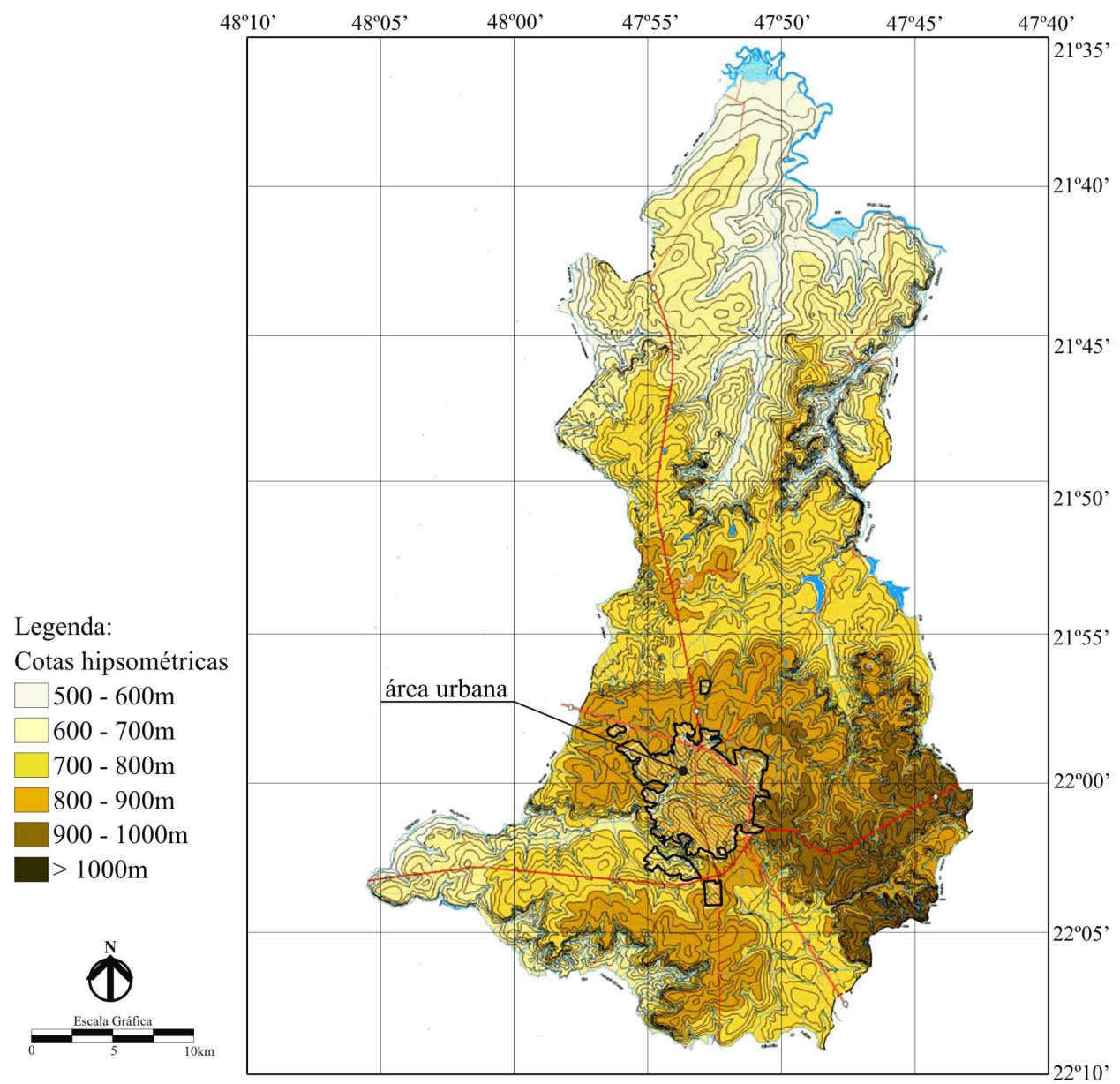

Figura 3: (a) Mapa geomorfológico do estado de São Paulo, com indicação do traçado do perfil topográfico passando pelo município de São Carlos, na região centro-norte do estado; (b) Perfil topográfico transversal do estado de São Paulo indicando a localização do município de São Carlos no topo das Cuestas Basálticas; (c) Mapa hipsométrico do município de São Carlos com indicação da área urbana.

Fonte: (a)(b) Adaptado de MONTEIRO, 1973; (c) Adaptado de PMSC, 2004. 


\section{- Geologia}

Quanto aos aspectos geológicos, o Planalto Residual de São Carlos apresenta quatro tipos litológicos: Formação Botucatu, Formação Serra Geral, Grupo Bauru e Formações superficiais (GONÇALVES, 1986). Nesse sentido, o município de São Carlos está assentado sobre as rochas do Grupo São Bento, constituídas pelos arenitos da Formação Botucatu e pelos magmatitos básicos da Formação Serra Geral. Sobre essas rochas ocorrem os conglomerados e arenitos do Grupo Bauru, e, em seguida, cobrindo toda a região, aparecem os Sedimentos Cenozóicos. Essas formações podem ser estratigraficamente visualizada na Figura 4 que mostra parte de extenso perfil geológico.

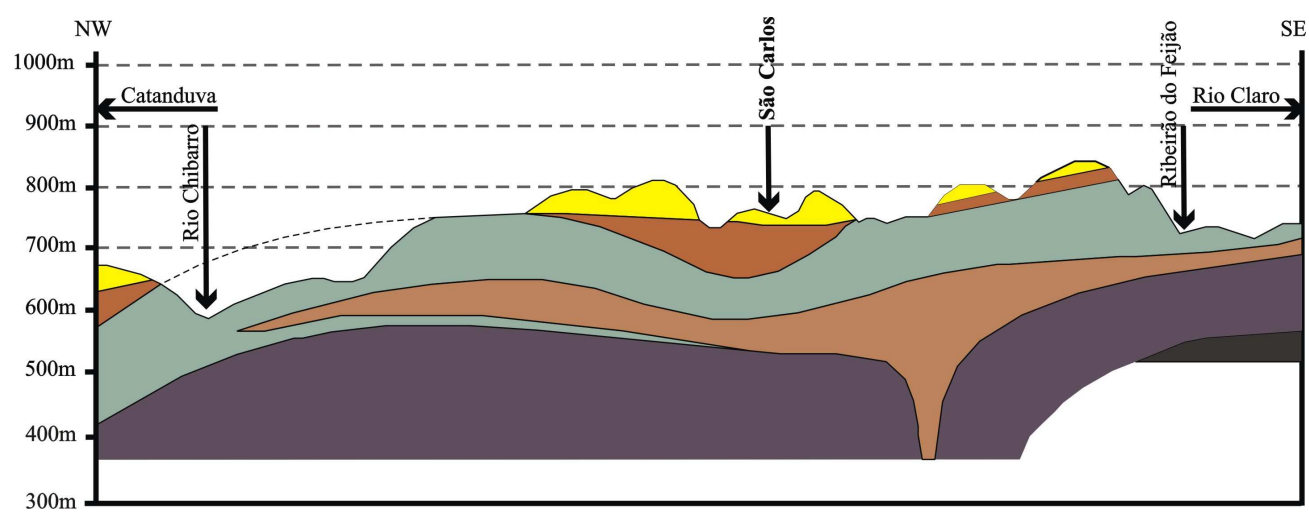

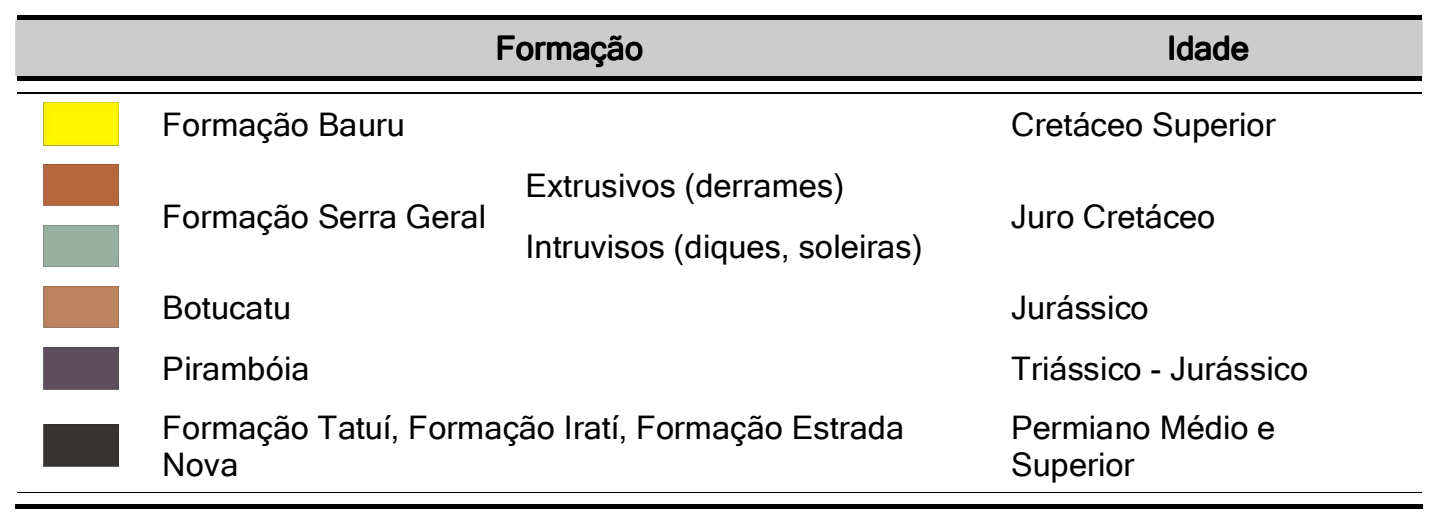

Figura 4: Perfil geológico da região de São Carlos.

Fonte: Adaptado de DAEE, 1974.

\section{- Pedologia}

Os solos do município de São Carlos apresentam forte correlação com as formas de relevo e tipo de material de origem (litologia). Verifica-se, assim, a presença de solos predominantemente argilosos nas cotas mais elevadas; solos rasos e afloramento de rochas nas escarpas; e solos de textura média (teor de argila entre 15 
e 35\%) nas áreas com altitudes menores. Nestas últimas, verificam-se, ainda, extensas áreas de solos muito arenosos e profundos.

De maneira geral, o município de São Carlos é caracterizado por solos de alta permeabilidade, sendo constituído, em sua maioria, por zonas de solo latossolovermelho-amarelo e de areia quartzosa profunda, com característica arenosa.

Na Figura 5 pode ser observada a distribuição das classes de solo que ocorrem na região do município, com indicação da área urbana na cor cinza.

Legenda:

Principais tipos de solo

LR - Latossolo Roxo

LE - Latossolo Vermelho Escuro

LV - Latossolo Vermelho

Podzólico Vermelho Amarelo

Terra Roxa Estruturada

Areia Quartzosas Profundas

Solos Litólicos

Solos Hidromórficos
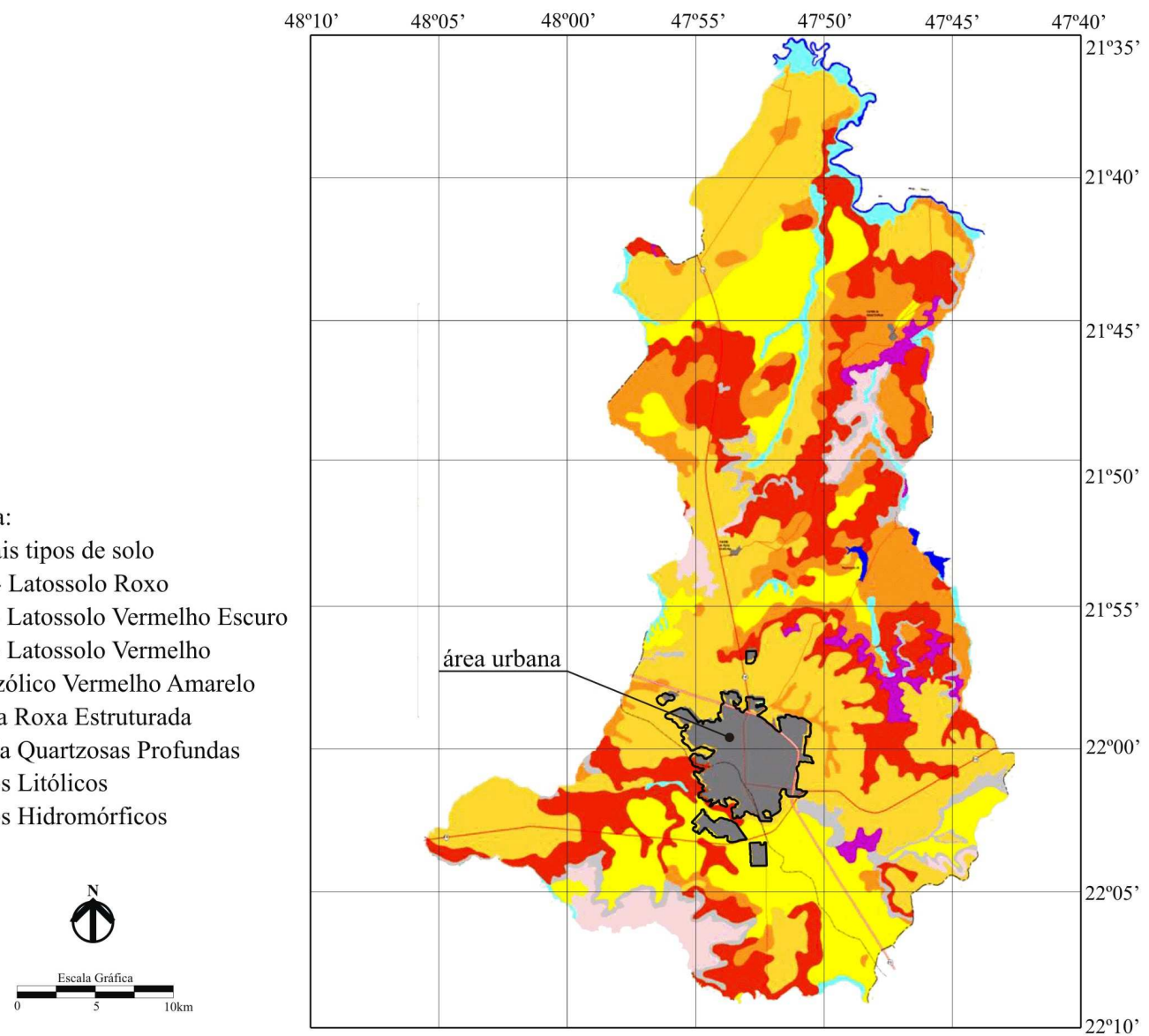

Figura 5: Mapa dos principais tipos de solo no município de São Carlos, com indicação da área urbana na cor cinza.

Fonte: Adaptado de PMSC, 2004.

\section{- Hidrologia}

O município de São Carlos está localizado em duas grandes bacias hidrográficas. Aproximadamente $1 / 3$ de sua área - porção Sul do território municipal está inserida na macro bacia hidrográfica Tietê-Jacaré (UGRHI $\left.{ }^{8} 13\right)$ e os $2 / 3$ restantes na macro bacia do rio Mogi-Guaçu (UGRHI 9) - porção Norte.

\footnotetext{
${ }^{8}$ Unidade de Gerenciamento de Recursos Hídricos.
} 
A porção das duas macro bacias dentro do limite municipal de São Carlos pode ser subdividida em dez microbacias, demonstradas na Figura 6. A macro bacia MogiGuaçú compreende 7 micro bacias, assim descritas em decrescente de tamanho: do ribeirão do Quilombo, com 30.173 ha; do ribeirão das Araras, com 20.044 ha; do ribeirão das Cabeceiras, com 6.960 ha; do ribeirão das Guabirobas, com 5.722 ha; do rio Mogi-Guaçu, com 4.167 ha; do rio Chibarro, com 3.541 ha; e do ribeirão do Pântano, com 1.685ha. A macro bacia Tietê-Jacaré compreende, por ordem decrescente de tamanho: do ribeirão do Monjolinho, com 20.610 ha; do ribeirão do Feijão, com 12.560 ha; e do rio Jacaré-Guaçú, com 8.216 ha.

A micro bacia hidrográfica do ribeirão do Monjolinho é considerada especialmente importante por abranger a zona urbana na sua quase totalidade, com exceção do condomínio Samambaia e os distrito de Água Vermelha e Santa Eudóxia (localizados na microbacia do ribeirão do Quilombo).

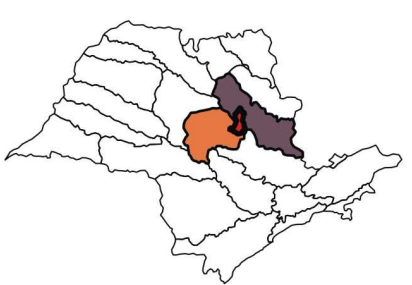

Legenda:

Macro Bacia Mogi-Guaçú

$\square$ das Araras

Mogi-Guaçú

das Guabirobas das Cabeceiras

Chibarro

do Quilombo

do Pântano

Macro Bacia Tietê-Jacaré

$\checkmark$ do Monjolinho

$\square$ do Feijão

$\square$ do Jacaré-Guaçú

Área urbanizada

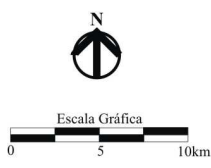

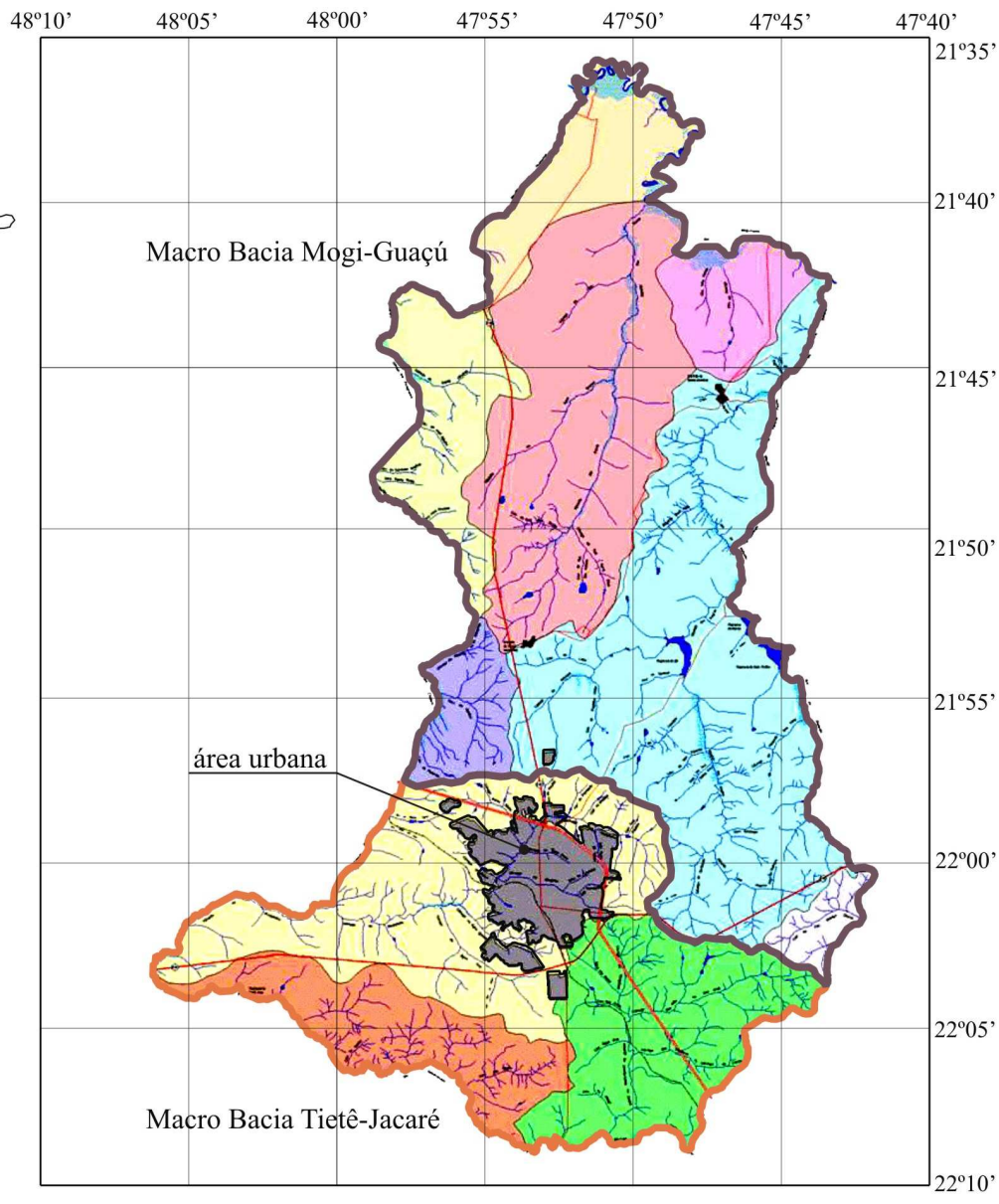

Figura 6: Mapa indicativo da porção das duas macro bacias dentro do limite municipal de São Carlos, subdividido em dez microbacias, com indicação da área urbana em cinza.

Fonte: Adaptado de PMSC, 2004. 


\section{- Vegetação}

A região tem o cerrado como tipo predominante de vegetação original, caracterizado por uma formação florestal herbáceo-lenhosa, herbáceo-arbustiva, com árvores perenifólias (GONÇALVES, 1986). Conforme Oliveira (1996), o cerrado apresenta uma fisionomia que varia desde campo cerrado até cerradão, atingindo 6 metros de altura. Esse tipo de vegetação está associado aos terrenos arenosos de topografia quase plana que se estendem ao norte, até as barrancas do rio Mogi-Guaçu e, ao sul, até as bordas do vale do rio Jacaré-Guaçu (BORTOLLUCCI, 1991).

No entanto, atualmente resta muito pouco da vegetação original. A maior parte das áreas não urbanizadas do município está ocupada por pastagens, plantações, reflorestamento e mineração (BORTOLUCCI, 1991, FONTES, 1998). Segundo Oliveira, a maior parte das terras que circundam o núcleo urbano está ocupada por pastagens, exceto no lado oeste, em direção a lbaté, onde são encontradas culturas de cana-de-açúcar. À Leste do perímetro urbano existem as áreas de reflorestamento (Pinus).

$\mathrm{Na}$ área urbana, a vegetação original foi reduzida a alguns fragmentos florestais, principalmente nas imediações do bairro Cidade Aracy, onde a textura arenosa do solo compromete o uso agrícola. Nestas áreas, a vegetação se apresenta mais aberta e baixa (OLIVEIRA, 1996).

Apesar da reduzida área de vegetação nativa no município devido à ocupação agrícola e devastação contínua é possível encontrar áreas preservadas. Um dos fragmentos florestais de maior valor está localizado ao norte da área urbana, no interior da Fazenda Canchim de propriedade da Empresa Brasileira de Pesquisa Agropecuária - EMBRAPA, onde a vegetação é mais robusta, compondo um remanescente de mata.

Conforme SOARES et al. (2003), os poucos fragmentos da vegetação original estão extremamente esgotados devido ao corte seletivo das espécies, mas também pelos fogos acidentais constantes que ocorrem durante a preparação da cana-deaçúcar antes do corte ou na renovação do pasto, ou mesmo por aqueles causados criminalmente para diminuir o valor ambiental das áreas nativas. 


\section{CARACTERÍSTICAS GEOURBANAS}

A área urbana localiza-se na parte sul de São Carlos e abrange uma área de $67,52 \mathrm{~km}^{2}$ - o que representa apenas $6 \%$ da área total do município; das quais apenas $33 \mathrm{~km}^{2}$ é, de fato, ocupada. A cidade encontra-se a uma altitude média de $856 \mathrm{~m}$ acima do nível do mar, em uma das áreas de maior altitude do município (ver Figura 3).

Com relação aos aspectos demográficos, em 2007, o município contava com uma população estimada de 212.956 habitantes (IBGE, 2009), dentre os quais $95,1 \%$ residiam em área urbana. $O$ crescimento demográfico do município no período entre 1970 e 2000 foi superior ao crescimento demográfico do estado de São Paulo e do Brasil para o mesmo período (ver Tabela 1).

O último Censo Demográfico, realizado em 2000, atestou que a população de São Carlos cresceu 2,25\% entre os anos de 1991 e 2000, enquanto a taxa geométrica de crescimento populacional do estado de São Paulo foi de $1,60 \%$ e do Brasil $1,63 \%$ (PMSC, 2004).

Tabela 1: Taxa geométrica de crescimento de 1940 a 2000: São Carlos, estado de São Paulo e Brasil.

\begin{tabular}{cccc}
\hline Período & São Carlos & Estado de São Paulo & Brasil \\
\hline \hline $1940-1950$ & $-0,18 \%$ & $2,50 \%$ & $2,39 \%$ \\
$1950-1960$ & $2,66 \%$ & $3,39 \%$ & $2,99 \%$ \\
$1960-1970$ & $3,25 \%$ & $3,39 \%$ & $2,89 \%$ \\
$1970-1980$ & $3,41 \%$ & $3,33 \%$ & $2,48 \%$ \\
$1980-1991$ & $2,57 \%$ & $2,13 \%$ & $1,93 \%$ \\
$1991-2000$ & $2,25 \%$ & $1,60 \%$ & $1,63 \%$ \\
\hline \hline
\end{tabular}

Fonte: PMSC, 2004.

O mesmo período mostra que São Carlos passou por intenso processo de urbanização de sua população. Em 1940, a população urbana era de 25.746 habitantes, a qual correspondia a $53 \%$ da população total do município (IBGE, 1940). Em 2000, a população urbana passou para 183.369 habitantes, representando $95,1 \%$ da população total (IBGE, 2000). A Tabela 2 mostra a distribuição numérica e percentual das populações urbana e rural do município de São Carlos, de 1940 a 2000. 
Tabela 2: Distribuição numérica e percentual das populações urbana e rural do município de São Carlos, de 1940 a 2000.

\begin{tabular}{cccccc}
\hline Ano & Pop. Urbana & Pop. Rural & Pop. Total & \% Urb. & $\begin{array}{c}\text { \% Cresc. } \\
\text { Pop. Urbana }\end{array}$ \\
\hline \hline 1940 & 25.746 & 22.863 & 48.609 & 53,0 & - \\
1950 & 32.703 & 15.028 & 47.731 & 68,5 & 27,0 \\
1960 & 52.817 & 15.550 & 68.367 & 77,3 & 61,5 \\
1970 & 76.681 & 9.704 & 86.385 & 88,8 & 45,2 \\
1980 & 109.167 & 10.375 & 119.542 & 91,3 & 42,4 \\
1991 & 148.411 & 9.810 & 158.221 & 93,8 & 36,0 \\
2000 & 183.433 & 9.565 & 192.998 & 95,0 & 23,6 \\
\hline \hline
\end{tabular}

Fonte: DEVESCOVI, 1987; REBELATTO, 1991; IBGE, 2009.

Para compreender a dinâmica do crescimento de São Carlos e o cenário atual faz-se necessário entender o processo de ocupação do território e os fatores que impulsionaram o desenvolvimento da cidade. Neste sentido, Santos (1997), afirmou que o espaço geográfico deve ser considerado como um conjunto de realizações através de funções e de formas que se apresentam como testemunho de uma história escrita por processos do passado e do presente. Souza (1999) e Carlos (1992), com base nessa colocação, afirmaram que o espaço urbano é a expressão espacial do modo de produção - reproduz, num momento, vários momentos da história.

\subsection{Ocupação do território e consolidação do núcleo urbano}

A cidade de São Carlos foi fundada em 04 de novembro de 1857. De acordo com Devescovi (apud REBELATTO, 1991), a ocupação da região de São Carlos deuse em um contexto de conquista do território paulista pelo desenvolvimento da economia cafeeira, a partir do último quarto do século XIX até a crise de 1929.

São Carlos nasceu em terras da antiga Sesmaria do Pinhal, em virtude de uma via de penetração nos "sertões de Araraquara". Essa estrada permitiu à Sesmaria do Pinhal, nome decorrente da presença de "araucarias" (o pinheiro Brasileiro) naquela região, que iniciasse o povoamento por seu proprietário, Capitão Carlos Bartholomeu de Arruda e seu filho, Manoel Joaquim Pinto de Arruda, em janeiro de 1786. Entretanto, coube ao filho mais moço do Capitão Carlos Bartholomeu, Carlos José Botelho, herdeiro de todas sesmarias da família, o verdadeiro desbravamento da região e o título de fundador de São Carlos. A demarcação da Sesmaria do Pinhal, no entanto, deu-se somente em 1831, quando Carlos José de Arruda Botelho requereu ao 
juiz da Vila da Constituição (atual Piracicaba), plantando o primeiro cafezal poucos anos depois e atraindo inúmeros colonos vindos de Minas Gerais.

A chegada da lavoura de café proporcionou a efetiva fixação dos primeiros habitantes na região, por volta de 1840. Em 1857, foi inaugurada a primeira capela, um desejo de Carlos José de Arruda Botelho, distando $12 \mathrm{~km}$ da sede da Sesmaria. De acordo com Mendes (2005), a ocupação urbana se deu a partir dessa capela (marco inicial da cidade, onde atualmente está edificada a Catedral de São Carlos), com edificação de ranchos de madeira cobertos de sapé e das primeiras casas de telhas pertencentes ao Conde do Pinhal, se expandindo em direção ao Sul até alcançar o Córrego do Gregório. Segundo Rebelatto (1991), uma das formas que o grupo social dominante encontrou para iniciar o processo de constituição do núcleo urbano foi de doar terras ao redor do marco inicial - a capela - a quem se dispusesse a construir casas próprias de moradia.

No mesmo ano da edificação da capela, São Carlos já era Distrito (Distrito da Paz), ligado a Araraquara, e no ano seguinte foi elevado à Freguesia. Em 1865, por Lei da Assembléia Provincial, São Carlos do Pinhal foi elevado a Vila e, em abril de 1880, a Cidade.

Contudo, a lavoura cafeeira encontrou sérias dificuldades para sua expansão no início do povoamento e não se afirmava, ainda, na região, como produto exclusivamente comercial, o que comprometia o desenvolvimento de São Carlos. Os obstáculos encontrados traduziam-se, sobretudo, na pouca disponibilidade de mão-deobra local e no isolamento e na distância da região de São Carlos em relação aos centros exportadores.

O fortalecimento da comercialização do café ocorreu, de fato, após 1860, tornou-se a principal atividade da região em 1884, beneficiada pela construção da ferrovia no mesmo ano e pela implementação de mão-de-obra estrangeira. A construção da ferrovia veio atender às exigências dos fazendeiros importantes da região que precisavam garantir o escoamento rápido do produto de suas propriedade para os centros exportadores, mas também concorreu para o aumento da população na cidade, em busca de trabalho nas lavouras de café - processo amplamente estimulado pela política de incentivo à imigração, principalmente de italianos, seguidos de portugueses e alemães (BORTOLUCCI, 1991).

A partir do exposto, nota-se que a atividade cafeeira foi fundamental para a consolidação do processo de ocupação do território e consolidação do núcleo urbano de São Carlos. Bortolucci (1991) mencionou que "onde existia café, havia impulso demográfico", tanto nas atividades desenvolvidas na lavoura, com nas atividades 
tipicamente urbanas. Esse foi um sinal característico da expansão cafeeira e que estimulou, de uma forma que não ocorreu com a atividade açucareira do Nordeste, o processo de urbanização das cidades. Assim, nos últimos anos do século XIX e no início do século $X X$, a cidade de São Carlos já começava a apresentar uma dinâmica que, ainda integrada aos movimentos econômicos do café, apontava para uma futura autonomia urbana relativa.

\subsection{Da cafeicultura a industrialização}

A partir dos anos 1920, a cultura do café passou apresentar sinais evidentes de decadência, principalmente pelo esgotamento do solo da região. Com a crise de 1929, toda economia cafeeira foi abalada. Vários fazendeiros viram-se na contingência de vender suas terras e tornou-se urgente a necessidade de substituição da atividade agrícola do café por atividades mais rentáveis, no sentido de fazer o município recuperar o antigo ritmo de crescimento e sair do período de debilidade econômica.

Entretanto, o papel de lideranças nas atividades industriais coube aos imigrantes e, muitas vezes, àqueles que não passaram pela condição de colonos em fazendas de café e que vieram diretamente para a cidade. Porém, nesta primeira fase de industrialização em São Carlos, as indústrias eram de fabricação de bens de consumo ou muito ligadas à atividade cafeeira (BORTOLUCCI, 1991).

A cidade de São Carlos foi um dos centros urbanos onde os movimentos industrializantes, a partir dos anos 1940, ocorreram com uma intensidade relativamente expressiva no contexto do conjunto do território paulista (REBELATTO, 1991), consolidando a econômica urbano-industrial e o núcleo urbano. A implantação físico-territorial das unidades industriais seguiu as tendências iniciais: ao longo da ferrovia - na vila Prado ou em áreas limítrofes ao centro comercial - e próximas a Estação Ferroviária. A partir daí, a tendência de aumento populacional na cidade de São Carlos, em detrimento do campo, era irreversível. Essa tendência foi acentuandose cada vez mais, conforme atestado pela distribuição numérica e percentual das populações urbana e rural do município de São Carlos, entre 1940 e 2000, conforme evidencia a Tabela 2.

\subsection{Processo de urbanização e a conformação do traçado urbano.}

Devescovi (apudREBELATTO, 1991) afirma que o processo de urbanização da cidade de São Carlos pode ser compreendido em três períodos, e suas conseqüentes características urbanas, pautados no binômino café-indústria. O primeiro período iniciase no último quarto do século XIX, quando se dá a formação do núcleo urbano de São 
Carlos e o início da hegemonia cafeeira, estendendo-se até 1920. Nesse período, o núcleo urbano foi marcado inicialmente pelo traçado ortogonal de ruas e praças. Bortolucci (1991) salienta que a preferência pelo traço ortogonal foi outra característica das cidades surgidas sob a égide do ciclo cafeeiro.

Em São Carlos, o plano ortogonal foi orientado a partir do eixo Norte-Sul definido por uma importante via, onde hoje é a avenida São Carlos, a qual teve posição de destaque no traçado urbano, seja pela maior largura em relação às demais ruas, seja pelas atividades instaladas às suas margens (BORTOLUCCI, 1991). O arruamento inicial seguiu o traçado rigidamente ortogonal definido por eixos Norte-Sul e Leste-Oeste, formando algumas quadras de noventa por noventa metros, localizadas ao redor da capela edificada em 1857.

Em 1867, a doação das terras da Sesmaria do Monjolinho, após dez anos de existência de São Carlos, permitiu a expansão da cidade também na direção norte, mantendo o mesmo traçado ortogonal inicial, facilitado pelo prolongamento das ruas existentes (BORTOLUCCI, 1991).

Antes de findar o século, surgiram novos bairros resultantes, basicamente, do prolongamento de ruas já existentes e seguindo ainda fielmente o traçado inicial. Entretanto, em 1884, a construção da linha ferroviária passando a Sudoeste do núcleo inicial proporcionou o surgimento da Vila Operária Ana Prado - que veio a tornar-se o bairro Vila Prado - e Vila Isabel, as quais contribuíram para a descaracterização do traçado original do tecido urbano.

Bortolucci (1991) afirmou que até a década de 40, em praticamente toda a área urbana, o traçado orientado pelos eixos Norte-Sul e Leste-Oeste foi mantido apenas com poucas exceções, com no caso das vilas operárias citadas anteriormente. Dessa forma, o processo de expansão urbana, nesse período, foi caracterizado pelo anexo de malhas parciais em torno do núcleo central, em um movimento predominantemente direcionado para a estação ferroviária e para o leito da estrada de ferro, eixo viário que se constituiu, cronologicamente, como o segundo elemento físico de referência para a estruturação e expansão da malha urbana (REBELATTO, 1991).

O segundo período de urbanização de São Carlos compreendido por Devescovi (apud REBELATTO, 1991) corresponde ao momento de transição da cafeicultura para a industrialização, situando-se entre os anos de 1920 e 1940. Entretanto, durante este período notou-se que o aspecto do tecido urbano não sofreu grandes mudanças, caracterizado, apenas, pela expansão da malha urbana obedecendo, ainda, o traçado ortogonal definido pelos eixos Norte-Sul e Leste-Oeste do núcleo inicial. 
Finalmente, o terceiro período da urbanização citado por Devescovi (apud REBELATTO, 1991) foi determinado pelo predomínio da economia urbano-industrial, o qual engloba a época entre os anos 1940 e 1970. A partir de então, expansão da malha urbana deu-se em função de outros fatos econômicos e históricos, como o crescimento da indústria, o crescimento populacional e a modernização do setor de transportes (AGUIAR, 1989).

Mendes (2005) analisou detalhadamente esse último período de urbanização compreendido após os anos 40. Segundo o autor, a expansão da malha urbana se deu, sobretudo, pela evolução das áreas loteadas, a qual pode ser dividida, basicamente, em três períodos. O primeiro se refere ao momento compreendido entre os anos de 1940 a 1950. Este se caracteriza por uma relação de semelhança entre o aumento da população e o das áreas loteadas. O segundo período, compreendido entre 1950 a 1960, aludiu ao início de um processo de desvinculação entre os dois aspectos abordados - aumento da população vs. área loteadas. A partir de 1960, verificou-se o terceiro período, caracterizado pela confirmação da desvinculação entre crescimento populacional e o de áreas loteadas.

O último período foi subdividido pelo autor (op. cit.) em quatro sub-períodos, caracterizados diferentemente quanto ao crescimento de áreas loteadas: de 1960 a 1970, apresentando crescimento bastante representativo; de 1970 a 1980, caracterizado por certa desaceleração do crescimento; de 1980 a 2000, em que o crescimento de áreas loteadas se acentuou novamente; e de 2000 a 2002, indicando um crescimento ainda maior do que o apresentado entre 1960 e 1970.

\subsection{Expansão urbana por áreas loteadas a partir da década de 70 e vetores de ocupação urbana em São Carlos.}

Rebelatto (1991) observou que até a década de 70, São Carlos tinha sofrido uma ocupação extremamente rarefeita, com grande quantidade de terrenos desocupados no interior da cidade ${ }^{9}$. Assim, a partir no início da década de 70 , os loteamentos aprovados eram localizados, em sua grande maioria, nos espaços vazios existentes na cidade, garantindo adensamento da ocupação do núcleo urbano. Estes vazios concentravam-se no eixo da avenida São Carlos em direção a região Leste da cidade. Alguns bons exemplos são: Vila Arnaldo, Jardim Brasil, Parque São José, Chácara São Caetano, Vila Costa do Sol etc.

\footnotetext{
${ }^{9} \mathrm{O}$ autor expôs que a ocupação extremamente rarefeita deu-se num contexto de crescimento demográfico pautado pela existência de surtos migratórios a partir de meados dos anos 40. A quantidade de terrenos desocupados no interior da cidade era grande, a tal ponto que sua existência tornou-se uma das preocupações correntes já no final da década de 40.
} 
O autor (op. cit.) salienta que isso ocorreu a despeito da expansão da zona urbana ocorrida em 1972, onde a ampliação se deu com a alteração do perímetro urbano a Oeste. Apenas o Jardim Botafogo e o Jardim Boa Vista II foram implantados se valendo dessa alteração. Todos os outros loteamentos aprovados neste período, ou procuravam preencher terrenos desocupados no interior da cidade, ou se acercavam da rodovia Washington Luiz - limite urbano da cidade na direção Leste.

Nos loteamentos implantados entre 1974 e 1976 observou-se a mesma tendência de preenchimento de vazios existentes, porém localizando-se mais a Leste da cidade, a partir da avenida São Carlos. Somente o Parque Primavera e o Parque Sabará faziam limite com a Rodovia Washington Luiz, sendo que os outros tenderam para as áreas da região central, como Centreville, Jardim Macarengo, Jardim Ricetti etc. Rebelatto (1991) salientou, contudo, que uma característica marcante da expansão urbana entre 1974 e 1976 foi a implantação de loteamentos voltados para classes sociais de maior poder aquisitivo, como Nova Santa Paula, Jardim Macarengo, Parque Sabará etc.

No período de 1977 a 1979, observou-se a tendência de se implantar loteamentos nos limites da zona urbana, expandida em 1972, como o Parque Santa Marta e prolongamento do Jardim Boa Vista. Rebelatto (1991) destacou como característica marcante deste período a transposição da rodovia Washington Luiz (SP310), que até o momento tinha se mostrado como obstáculo físico à expansão da malha urbana na direção Leste. Alguns exemplos são: Jardim Tanguará e Jardim Novo Horizonte.

Quanto à expansão além da Washington Luiz, ocorrida nesse período, o autor (op.cit.) afirmou: “(...) Pode-se deduzir, até, que a rodovia em questão tenha responsabilidade no adensamento verificado nos períodos anteriores, agindo como limite físico da urbanização em sua direção". A transposição da rodovia também está ligada a ressalva de expansão na direção Oeste, visto que os loteamentos implantados nessa porção da cidade se localizariam distante da região central. Esse distanciamento implicaria em problemas de transporte e de baixa valorização da área fator relevante em cidades de porte médio e pequeno com comércio centralizado.

Rebelatto (1991) destacou que o período compreendido entre os anos 1980 e 1982 foi preponderante a todos os outros em termos de área loteada. Com relação ao vetor de expansão urbana, observou-se a continuidade da ocupação após a rodovia, com a implantação do Parque Belvedere, Parque Residencial Maria Stella Fagá e Jardim São Rafael, entre outros. O autor (op. cit.) observou, ainda, que esse período destacou-se, também, pela implantação de loteamentos aprovados com critérios e 
requisitos inadequados, como a Cidade Aracy e o Parque Samambaia. Estes loteamentos foram implantados sem infra-estrutura mínima e com características claras de tentativa de valorização das terras localizadas entre eles a malha urbana existente - mecanismo largamente usado em cidades em expansão, na qual o poder público torna-se obrigado a levar infra-estrutura até o loteamento afastado, valorizando, por conseguinte, as áreas intermediárias.

A partir de 1983, constatou-se uma desaceleração nos empreendimentos imobiliários. No período de 1983 a 1985 foram aprovados apenas o Jardim Medeiros, o Jardim Rosas e o Parque Paraíso, com áreas reduzidas e todos a Oeste, a partir da avenida São Carlos. O mesmo ocorreu no período de 1986 a 1988, no qual poucos loteamentos foram aprovados - a maioria localizados nos limites da zona urbana. Rebelatto (1991) afirmou que os únicos pontos que chama atenção nesse período são: a criação de uma grande área industrial na região Sudeste (loteamento industrial CEAT) e a ampliação da ocupação após a rodovia, com a implantação do Jardim Munique.

Após 1988, novos loteamentos foram aprovados, praticamente em todas as direções, evidenciando a tendência de crescimento horizontal da malha urbana. A partir da década de 90 , outros eixos assumiram importância na dinâmica de expansão da malha urbana. São eles: a avenida Francisco Pereira Lopes (comumente chamada de Marginal), a avenida Getúlio Vargas (saída para São Paulo) e a própria rodovia Washington Luis. (BORTOLUCCI, 1991).

Atualmente, o traçado urbano tem ultrapassado todas as barreiras físicas que contiveram sua expansão em determinados momentos e o seu crescimento é mais acelerado nos quadrantes Oeste-Noroeste, em que se situam o Shopping Center Iguatemi e o bairro Santa Felícia (FONTES, 1998). São Carlos também revela, nos últimos anos, grande potencial de verticalização nas áreas centrais.

A Figura 7 apresenta a expansão da malha urbana de São Carlos, em intervalos de 10 anos, a partir de 1940 até 2002. Por meio dela, podemos observar como o crescimento urbano foi variado e limitado, a cada década, por questões de natureza antrópica, como a rodovia Washington Luiz ou imposições do meio físico, representadas pelos córregos urbanos, situados em fundos de vale, e pelas altas declividades das porções Sul-Sudeste. 
Legenda:
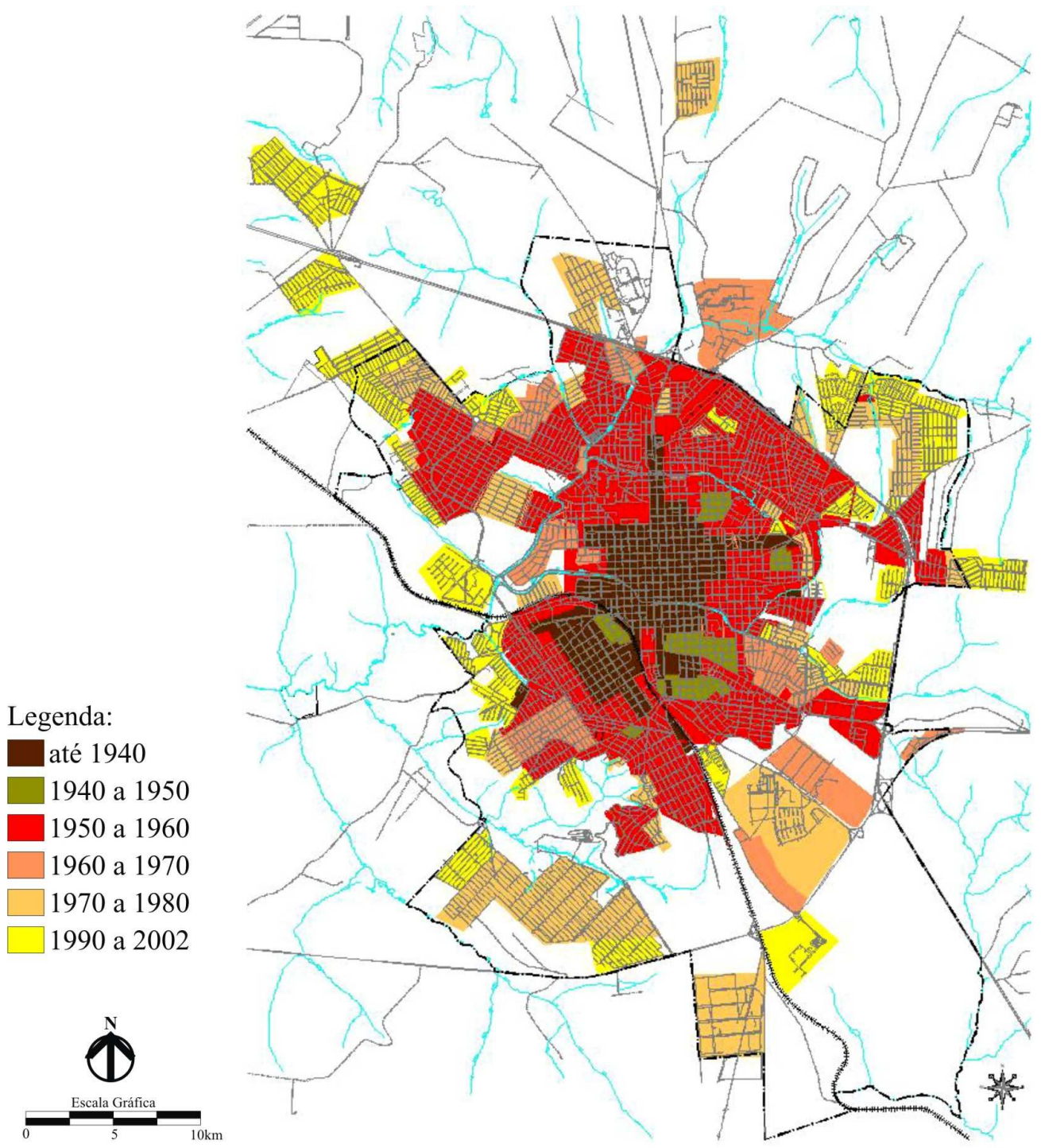

Figura 7: Expansão da malha urbana de São Carlos, em intervalos de 10 anos, a partir de 1940 até 2002.

Fonte: PMSC, 2004. 


\section{ASPECTOS CLIMÁTICOS}

As características climáticas de São Carlos, como em qualquer outra localidade, são condicionadas pela interação dos fatores estáticos (latitude, altitude, relevo etc.) e dinâmicos (massas de ar e sistemas atmosféricos atuantes) da região. Conhecidos os fatores estáticos, torna-se fundamental o conhecimento dos fatores dinâmicos, a fim de compreender o processo de circulação atmosférica que determina o rimo climático da cidade e define a gênese do clima do local.

Nesse sentido, torna-se fundamental o conhecimento da circulação atmosférica zonal $^{10}$ para compreender e caracterizar a circulação atmosférica secundária ${ }^{11}$ ou regional, uma vez que o clima local está inserido numa escala maior - o clima regional a qual Monteiro (1963) apontou como reveladora da verdadeira unidade geográfica.

A seguir, foram abordadas as massas de ar e a circulação atmosférica no estado de São Paulo, com fito de contextualizar a dinâmica atmosférica na cidade de São Carlos, objeto de estudo da presente investigação.

\subsection{Massas de ar e circulação atmosférica no estado de São Paulo: a escala zonal no âmbito da circulação regional.}

O estado de São Paulo possui uma situação peculiar na América do Sul: localiza-se na transição do Brasil meridional, permanentemente úmido, e o Brasil central, com alternância de períodos secos e úmidos bem definidos. Essa transição é marcada pela presença do Trópico de Capricórnio que passa exatamente sobre a cidade de São Paulo, a 2330'S. Nas proximidades deste paralelo encontra-se a zona de embate entre os dois sistemas atmosféricos que atuam na região em estudo: o sistema tropical, que se estende do equador ao trópico, e o sistema austral, que domina toda parte meridional do continente.

Nesse sentido, Monteiro $(1964,1973)$ salientou que o território paulista encontra-se na faixa de conflito entre os sistemas tropicais e intertropicais, sendo este conhecimento fundamental no entendimento do clima da região em estudo.

\footnotetext{
10 A circulação atmosférica Zonal ou primária é a responsável pela definição dos padrões de vento e pressão em larga escala, que se mantém ao longo do ano, determinando padrões dos diferentes climas do planeta (AYOADE, 1991).

11 Os sistemas circulatórios secundários estão inseridos na circulação Zonal. Tratam-se dos centros de ações positivos ou anticiclônicos e as depressões (centro de ações negativo), assim como as correntes perturbadas ou grande descontinuidades que atravessam toda a região (op. cit.).
} 
Nimer (1979) também apontou que, não apenas o território paulista, mas todo Sudeste brasileiro está numa região sobre a qual o choque entre o sistema de circulação do anticiclone móvel polar (massa Polar Atlântica) e o sistema de circulação do anticiclone subtropical semifixo do Atlântico Sul se dá, freqüentemente, em equilíbrio dinâmico. Essa circulação atmosférica na região, especialmente no verão período enfocado nesta pesquisa -, deriva, quanto à Climatologia Dinâmica, a unidade climática do Sudeste do Brasil.

Com relação às massas de ar atuantes sobre a região em estudo, Monteiro (1973) destacou que o território paulista é envolvido pelas principais correntes de circulação atmosférica da América do Sul: as massas tropicais - Atlântica e Continental - e Polar Atlântica, as quais são complementadas pela Equatorial Continental, oriunda da Amazônia Ocidental. Nesse sentido, Nimer (1979) também apontou que as características regionais de tempo no estado de São Paulo são influenciadas, principalmente, por três sistemas de circulação atmosférica. São elas:

- Massa Tropical Atlântica (mTa): Tem seu centro de origem no oceano Atlântico e apresenta característica quente é úmida, com grande poder de penetração para o interior do continente. Sua atuação sobre a região do estado de São Paulo dar-se por períodos prolongados durante todo o ano, com maior intensidade nos meses de outono, de inverno e de primavera. Sua permanência por tempo prolongado propicia o aquecimento da atmosfera, com tipos de tempo caracterizados por calmarias, baixa umidade relativa do ar e céu limpo.

- Massa Polar Atlântica (mPa): Tem sua fonte sobre o Atlântico, na latitude da Patagônia. A mPa é a única que não se manifesta sobre o estado pela expansão de sua área, exceto no inverno, quando se instala periodicamente. Nas demais estações a $\mathrm{mPa}$ se manisfesta pela atuação significativa de suas frentes, caracterizada por sua forte subsidência e umidade relativa e baixa temperatura. As frentes avançam principalmente sobre a parte meridional do território paulista até a bacia paulistana e, em muitos casos, além, dependendo de condições favoráveis.

- Massa Equatorial Continental (mEc): de origem na região amazônica, inicia sua expansão pelo estado na primavera. A mEc é caracterizada por sua elevada temperatura, atingindo o estado com alta umidade relativa, causando condensação e instabilidade, que podem provocar precipitações. Sua atuação se dá predominantemente no verão; 
De acordo com Monteiro (1964), a massa Polar Atlântica tem extrema importância na definição dos tipos de tempo no estado de São Paulo, devido a sua freqüência de atuação sobre a região nunca inferior a $25 \%$ e, por vezes, chegando a superar $50 \%$ do ano. A massa Polar Atlântica divide sua predominância com a massa Tropical Atlântica que chega a atingir freqüência superior a $50 \%$ em qualquer estação do ano.

Monteiro (1973) delineou, no território paulista, as diferentes feições climáticas nas duas unidades regionais: as controladas por massas equatoriais e tropicais e as controladas por massas tropicais polares. $\mathrm{O}$ autor (op. cit.) apontou nove sub-unidades com 17 feições climáticas, conforme a Figura 8.

De acordo com o esquema climático de Monteiro (1973), o município de São Carlos localiza-se na sub-unidade V - Centro Norte, cujas características foram abordadas a seguir.

\subsection{Sub-unidade climática V - Centro-Norte: o clima de São Carlos no âmbito da escala local.}

A sub-unidade $\mathrm{V}$ - Centro-Norte é individualizada pelo ritmo de circulação atmosférica regional que se justapõe às diversificações do relevo. A característica fundamental do Centro Norte é a existência de um período seco muito nítido, onde a freqüência da chuva diminui consideravelmente no sentido dos paralelos, culminando no setor Norte que se constitui na área de inverno mais nitidamente seca do estado. De acordo com o Monteiro (1973, p.123), "trata-se de uma área de acentuada participação da massa Tropical Atlântica submetida a passagens da massa Polar Atlântica".

A proposta de classificação climática de Monteiro (1973), ainda subdividiu o Centro-Norte em três grandes fácies distinguidas com relação à morfologia: (a) a parte setentrional da Depressão Paulista (Va); (b) o festão da "cuesta" e o lóbulo avançado do Planalto Ocidental ao norte da passagem do Tietê (Vb); e (c) o setor norte (Vc).

O município de São Carlos localiza-se na fácie b (Vb) (ver Figura 8) a qual apresenta ligeiro aumento na quantidade de precipitação no inverno devido ao efeito orográfico da Serra de São Carlos. Por este motivo, a região em estudo não apresenta invernos tão secos como os verificados no setor Norte do estado. Entretanto, apesar do aumento na incidência de precipitações, a distribuição das chuvas na área é desigual, tanto ao longo do ano como pelas regiões do território; além de irregularidades no espaço temporal (desvios anuais) - característica que predomina em toda sub-unidade $V$ do estado de São Paulo. 


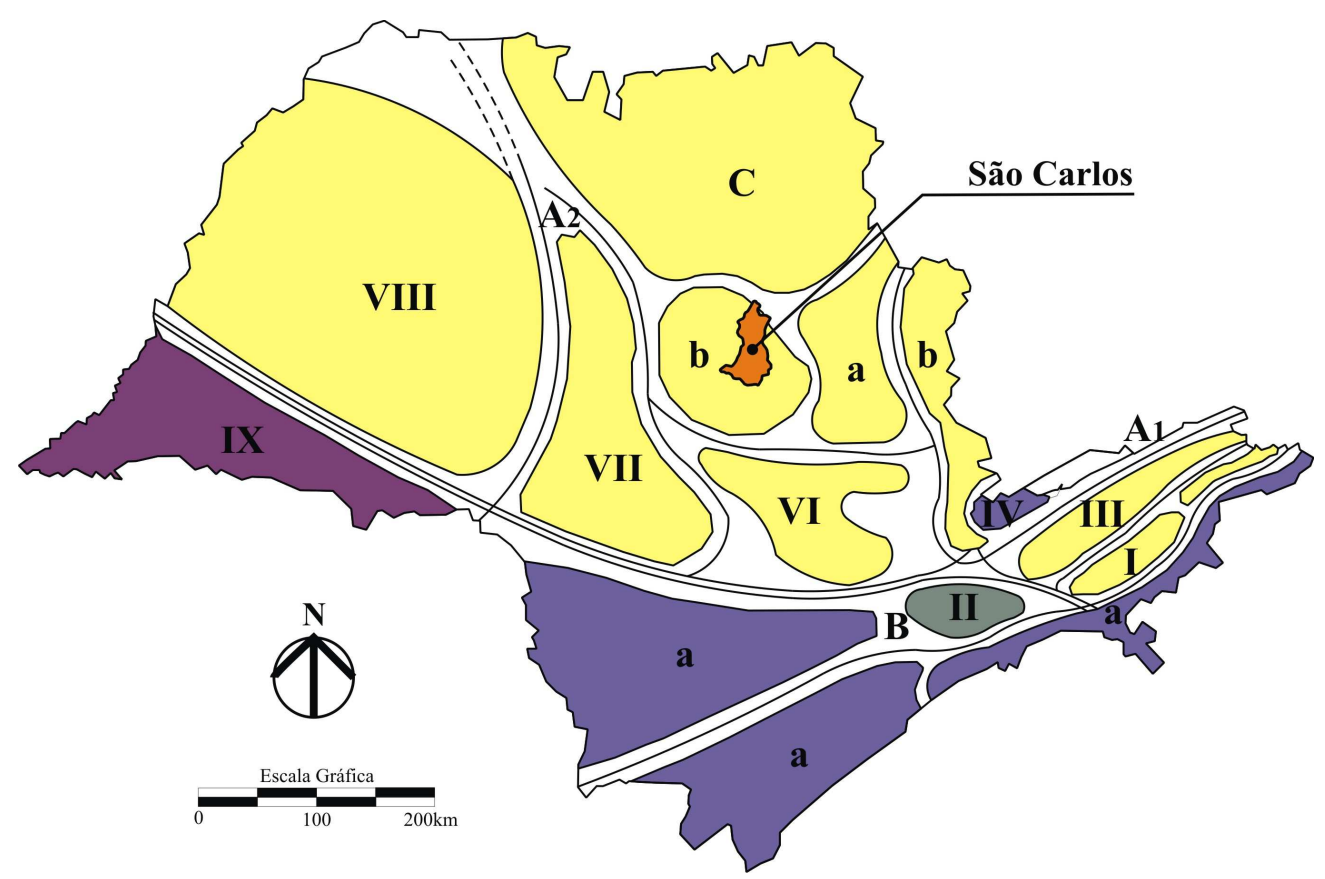

\begin{tabular}{|c|c|c|c|c|c|c|c|}
\hline \multirow{2}{*}{$\begin{array}{l}\text { Climas } \\
\text { zonais }\end{array}$} & \multirow{2}{*}{$\begin{array}{l}\text { Climas } \\
\text { regionais }\end{array}$} & \multicolumn{6}{|c|}{$\begin{array}{l}\text { Feições climáticas individualizadas nos climas regionais segundo as unidades } \\
\text { geomorfológicas }\end{array}$} \\
\hline & & Litoral & $\begin{array}{l}\text { Planalto } \\
\text { Atlântico }\end{array}$ & $\begin{array}{l}\text { Vale do } \\
\text { Paraíba }\end{array}$ & Mantiqueira & Depressão & $\begin{array}{c}\text { Planalto } \\
\text { Ocidental }\end{array}$ \\
\hline \multirow{5}{*}{ 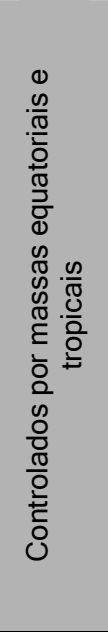 } & $\begin{array}{c}\text { A1 } \\
\text { Climas úmidos } \\
\text { das costas } \\
\text { expostas às } \\
\text { massas mT. }\end{array}$ & $\begin{array}{l}\text { I } \\
\text { Norte }\end{array}$ & $\begin{array}{c}\text { I } \\
\text { Bacia } \\
\text { superior } \\
\text { do } \\
\text { Paraíba }\end{array}$ & $\begin{array}{c}\text { III } \\
\text { Vale do } \\
\text { Paraíba }\end{array}$ & $\begin{array}{c}\text { IV } \\
\text { Serra } \\
\text { (borda do } \\
\text { Planalto) }\end{array}$ & & \\
\hline & \multirow{4}{*}{$\begin{array}{c}\text { A2 } \\
\text { Climas } \\
\text { tropicais } \\
\text { alternadament } \\
\text { e secos e } \\
\text { úmidos }\end{array}$} & & & & \multirow{4}{*}{$\begin{array}{l}\text { IV } \\
\text { Contrafortes }\end{array}$} & \multirow{2}{*}{$\begin{array}{c}\text { V } \\
\text { Setor } \\
\text { Norte }\end{array}$} & $\begin{array}{c}\text { V } \\
\text { Norte }\end{array}$ \\
\hline & & & & & & & $\begin{array}{c}\text { V } \\
\text { Serra de São } \\
\text { Carlos }\end{array}$ \\
\hline & & & & & & \multirow{2}{*}{$\begin{array}{c}\text { VI } \\
\text { "Percée } \\
\text { do } \\
\text { Tietê" }\end{array}$} & $\begin{array}{c}\text { VII } \\
\text { Serra de } \\
\text { Botucatu } \\
\end{array}$ \\
\hline & & & & & & & $\begin{array}{c}\text { VIII } \\
\text { Oeste }\end{array}$ \\
\hline \multirow{2}{*}{ 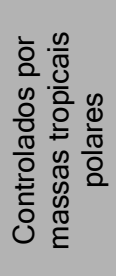 } & \multirow{2}{*}{$\begin{array}{c}\text { B } \\
\text { Climas úmidos } \\
\text { da face } \\
\text { oriental e sub- } \\
\text { tropical dos } \\
\text { continentes } \\
\text { dominado por } \\
\text { massa mT. }\end{array}$} & $\begin{array}{c}\text { II } \\
\text { Centro }\end{array}$ & $\begin{array}{c}\text { II } \\
\text { Bacia Paulis }\end{array}$ & & & & \\
\hline & & Sul & $\begin{array}{c}\text { Il } \\
\text { Bacia do } \\
\text { Paranapane }\end{array}$ & & & & $\begin{array}{c}\text { IX } \\
\text { Sudoeste }\end{array}$ \\
\hline
\end{tabular}

Figura 8: Esquema representativo das feições climáticas individualizadas no território paulista dentro das células climáticas regionais e das articulações destas nas faixas zonais. Fonte: Adaptado de MONTEIRO, 1973, p.125. 
Os índices pluviométricos, em São Carlos, definem a existência de duas estações bem distintas, definidas pelos seus índices pluviométricos: uma seca e uma chuvosa. A estação seca estende-se de abril a setembro, caracterizada por precipitações escassas, na ordem de $301,9 \mathrm{~mm}$, representando apenas $20,2 \%$ do total anual. Esse período também apresenta baixa umidade do ar, reduzida nebulosidade e menor temperatura do ar. Nesse período predominam as massas Tropical Atlântica e Polar Atlântica sobre a região (TOLENTINO, 1967).

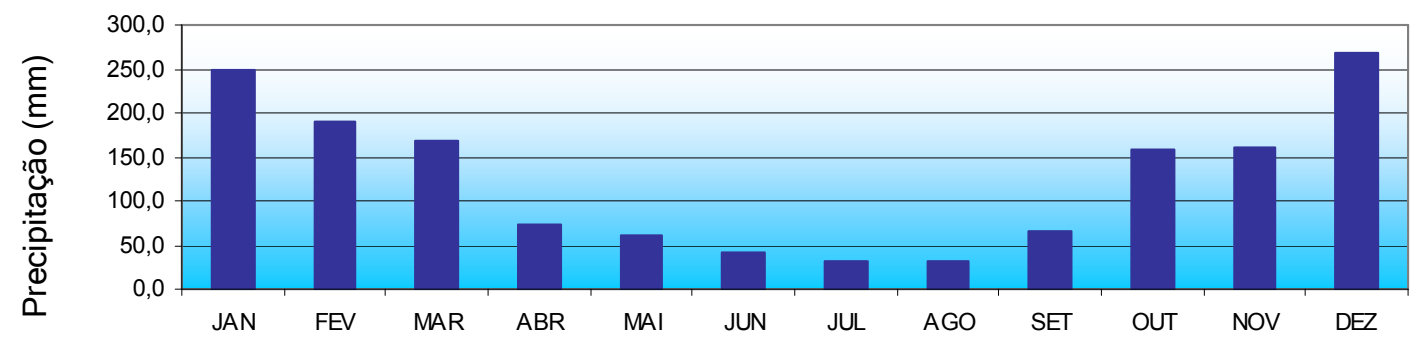

Figura 9: Totais pluviométricos mensais em São Carlos segundo as Normais Climatológicas (1961-1990)

Fonte: Adaptado de BRASIL, 1992.

A estação chuvosa ocorre nos meses de outubro a março, devido às incursões da massa Equatorial Continental e ao dinamismo da frente Polar Atlântica sobre a massa Tropical Atlântica, que responde, em grande parte, pela gênese das chuvas que se produzem durante a atuação de sistemas frontais nesse período do ano (MONTEIRO, 1973). A estação chuvosa é caracterizada, ainda, por elevadas temperatura do ar, alta umidade do ar e precipitações abundantes, na ordem de $1.193,2 \mathrm{~mm}$, que representa $78,8 \%$ do total anual. (TOLENTINO, 1967).

Com relação à influência da localização geográfica de São Carlos na determinação das características climáticas da cidade, Tolentino (1967) destacou que a inexistência de obstáculos naturais - serras ou outros acidentes geográficos desse tipo - permite a insolação e a ventilação intensa na área. Nesse sentido, Fontes (1998) salientou que a cidade é favorecida pela ventilação devido a área urbana estar localizada sobre o divisor de águas que limita as bacias hidrográficas do rio MogiGuaçu e Tietê, o que implica na inexistência de obstáculos naturais nos quadrantes NE e SE.

O regime dos ventos predominantes varia mediante o sistema de circulação atmosférica atuante, apresentando-se como um dos melhores indicativos do encadeamento sucessivo de tipos de tempo (VECCHIA, 1997). Nesse sentido, a 
presença dos anticiclones semifixos - Tropical e Polar Atlântico - revezam-se na coordenação e orientação das direções dos ventos predominantes na região.

$O$ anticiclone Tropical Atlântico responsabiliza-se pelos ventos oriundos do quadrante $\mathrm{E}$ a NE, enquanto que o anticiclone Polar Atlântico direciona os ventos do quadrante $S$ a SE. Na fase de transição, surgem os ventos do quadrante $W$, SW e NW, trazidos por linhas de instabilidades tropicais (calhas induzidas, entre outras) e responsáveis por elevadas velocidades do ar, devido ao processo de instabilidade atmosférica.

A intensa insolação na cidade, sobretudo no verão, também resulta no aumento da nebulosidade nos meses da estação chuvosa. Nesse período, as nuvens são formadas, na maioria das vezes, pela ascendência e resfriamento adiabático do ar. À medida que o ar é resfriado, a quantidade de vapor d'água que ele pode conter diminui, de modo que o ar ascendente torna-se saturado, daí ocorrendo a condensação, porém não, necessariamente, chuvas (NIMER, 1979).

A topografia formada por escarpas acentuadas resultando em linhas de drenagem próximas e amplas, também permitem o rápido escoamento das águas pluviais com profundos reflexos sobre a evaporação e a umidade atmosférica.

\subsection{Características e os tipos de tempo habituais do período de verão.}

Os meses correspondentes ao período de verão coincidem com a estação chuvosa, caracterizando-se por elevados índices pluviométricos (na ordem de 707,3 $\mathrm{mm}$, nos meses de dezembro a fevereiro, o que corresponde a $47,3 \%$ do total anual).

De acordo com Monteiro (1973), a evolução dos tipos de tempo no período de verão na região de São Carlos, assim como em todo território paulista, é influenciada, basicamente, por três fatores dinâmicos da circulação atmosférica regional: (a) domínio da massa Tropical Atlântica, (b) individualização e domínio da massa Tropical Continental e (c) incursões da massa Equatorial Continental.

No domínio da massa Tropical Atlântica, as chuvas mantêm íntima conexão com os fenômenos da frente Polar Atlântica, especificamente pelo cenário de instabilidade atmosférica na pré-frontal. $\mathrm{O}$ autor (op. cit.) ressalvou que o dinamismo da frente Polar Atlântica afeta a massa Tropical Atlântica por meio de fenômenos superiores. Essa dinâmica responde, na maioria das vezes, pela gênese das chuvas que se produzem durante a sua atuação.

A individualização e domínio da massa Tropical Continental se manifesta claramente pela sua atividade sobre a massa de ar fria, no eixo da frente Polar 
Atlântica, e sobre a massa Tropical Atlântica, numa calha perpendicularmente induzida àquele eixo (MONTEIRO, 1973). Nessa dinâmica, as chuvas conseqüentes da atuação da massa Tropical Continental, quente e seca, limitam-se, basicamente, às faixas de instabilidade das frentes.

Monteiro (1973) salientou, entretanto, que a atuação da massa Tropical Continental, individualizada e comprometida na circulação regional pelo dinamismo da frente Polar Atlântica, devido ao seu baixo teor de umidade, não implica em resultados pluviais significativos. Seus efeitos produzem-se, caracteristicamente, pelo aumento da temperatura no aquecimento pré-frontal.

O terceiro fator dinâmico da circulação atmosférica característico do período de verão são as incursões da massa Equatorial Continental - quente, úmida e instável. Essa dinâmica, segundo Monteiro (1973) é condicionada por frontogênese muito lenta no eixo da frente Polar Atlântica. Tavares e Silva (2008) salientaram, ainda, que as incursões dessa massa sobre a região em estudo, especialmente no verão, são facilitadas pelo sistema de baixas pressões no Chaco e pelas áreas deprimidas interiores, sendo responsáveis por grande parte das chuvas.

Os tipos de tempo habituais do período de verão são caracterizados, assim, pela sucessão de avanços periódicos de sistemas frontais sobre a região. Dessa forma, podemos distinguir períodos pré-frontais, períodos de avanço dos sistemas frontais e períodos pós-frontais.

O período pré-frontal apresenta cenário atmosférico estável, com bom tempo e céu claro. A temperatura máxima do ar é, freqüentemente, superior à média das máximas das Normais Climatológicas (Tabela 3), devido à intensa insolação nesse período do ano aliado à ausência de nebulosidade característica da fase de domínio de massas Tropicais. A umidade relativa do ar é reduzida devido ao aumento da temperatura do ar, o que favorece maior amplitude térmica diária. Os ventos sopram predominantemente do quadrante NE, proveniente do anticiclone Tropical. O período pré-frontal encerra-se com a fase a qual Monteiro (1963) denominou "prenúncio", que antecede a passagem de uma frente fria sobre a região.

O período de avanço corresponde à passagem da frente Polar Atlântica sobre a região. Esse período é caracterizado pelas chuvas produzidas por perturbações préfrontais resultantes da dinâmica da circulação regional. O momento do avanço do sistema frontal sobre a região é marcado por queda acentuada nos valores da temperatura do ar e conseqüente incremento nos índices de umidade relativa do ar. Há, ainda, o surgimento dos ventos de O, SO e NO, responsáveis por elevadas velocidades do ar, devido ao processo de instabilidade atmosférica, ao aparecimento de calhas induzidas, entre outros (VECCHIA, 1997). 
Tabela 3: Normais Climatológicas de São Carlos - período 1961-1990.

\begin{tabular}{|c|c|c|c|c|c|c|c|c|c|c|c|c|c|}
\hline \multirow[b]{2}{*}{ Meses } & \multicolumn{7}{|c|}{ Temperatura do ar $\left({ }^{\circ} \mathrm{C}\right)$} & \multirow{2}{*}{$\begin{array}{l}\text { Prec. } \\
(\mathrm{mm})\end{array}$} & \multirow{2}{*}{$\begin{array}{c}\text { Evaporação } \\
\text { total } \\
(\mathrm{mm})\end{array}$} & \multirow{2}{*}{$\begin{array}{l}\text { UR } \\
(\%)\end{array}$} & \multirow{2}{*}{$\begin{array}{c}\text { P.Atm } \\
(\mathrm{hPa})\end{array}$} & \multirow{2}{*}{$\begin{array}{c}\text { Insolação } \\
\text { total } \\
\text { (horas e } \\
\text { décimos) }\end{array}$} & \multirow{2}{*}{$\begin{array}{l}\text { Nebulosidade } \\
\qquad(0-10)\end{array}$} \\
\hline & Máx. & Mín. & Média & Máx. abs. & dia/ano & Mín. abs. & dia/ano & & & & & & \\
\hline Jan. & 26,8 & 17,5 & 21,6 & 35,7 & $27 / 71$ & 8,0 & $8 / 70$ & 248,7 & 97,9 & 76 & 885,7 & 106,3 & 7,1 \\
\hline Fev. & 27,2 & 17,7 & 21,8 & 34,6 & $05 / 71$ & 8,0 & $16 / 70$ & 191,4 & 93,7 & 75 & 886,3 & 107,4 & 6,8 \\
\hline Mar. & 27,0 & 17,2 & 21,0 & 33,5 & $02 / 81$ & 6,0 & $3 / 70$ & 167,3 & 108,7 & 73 & 886,7 & 111,6 & 6,0 \\
\hline Abr. & 25,7 & 15,5 & 18,7 & 31,6 & $14 / 61$ & 5,9 & $25 / 71$ & 73,2 & 110,4 & 68 & 886,8 & 119,5 & 4,9 \\
\hline Mai. & 23,6 & 13,2 & 16,3 & 29,4 & $01 / 66$ & 0,7 & $31 / 79$ & 61,6 & 110,3 & 67 & 889,4 & 121,4 & 4,4 \\
\hline Jun. & 22,7 & 12,0 & 14,4 & 29,3 & $29 / 72$ & 1,0 & $01 / 79$ & 40,4 & 109,1 & 66 & 890,3 & 120,1 & 4,1 \\
\hline Jul & 22,1 & 11,4 & 14,2 & 29,6 & $20 / 63$ & $-0,1$ & $18 / 75$ & 30,8 & 132,6 & 61 & 860,4 & 118,6 & 3,6 \\
\hline Ago. & 24,3 & 12,5 & 15,5 & 33,2 & $30 / 63$ & 2,2 & $15 / 78$ & 30,9 & 173,6 & 54 & 859,1 & 107,3 & 3,7 \\
\hline Set. & 25,0 & 14,2 & 16,6 & 36,0 & $26 / 88$ & 3,8 & $2 / 70$ & 65,0 & 175,5 & 58 & 888,5 & 104,4 & 4,6 \\
\hline Out. & 24,7 & 14,7 & 18,3 & 36,4 & $12 / 63$ & 5,2 & $12 / 69$ & 157,8 & 151,6 & 80 & 886,8 & 108,7 & 7,1 \\
\hline Nov. & 25,7 & 16,0 & 19,6 & 36,9 & $17 / 85$ & 6,0 & $24 / 70$ & 160,8 & 132,3 & 67 & 885,6 & 98,9 & 6,0 \\
\hline Dez. & 25,2 & 17,2 & 19,6 & 33,6 & $09 / 88$ & 8,0 & $26 / 69$ & 267,2 & 102,1 & 73 & 885,3 & 86,9 & 6,8 \\
\hline Ano & 25,0 & 14,9 & 18,1 & 36,9 & 17/11/85 & $-0,1$ & $18 / 07 / 75$ & 1495,1 & 1497,9 & 68 & 882,7 & 1311,2 & 5,4 \\
\hline
\end{tabular}

Fonte: BRASIL, 1992. 
O período pós-frontal é caracterizado, inicialmente, pelo domínio absoluto da massa Polar Atlântica, que ocorre logo após a passagem da frente fria sobre a região. No verão, o domínio na pós-frontal é caracterizado, freqüentemente, por leve declínio da temperatura do ar, visto que a massa Polar Atlântica chega sobre a região em estudo sensivelmente modificada devido ao maior aquecimento do continente. Nesse sentido, deve-se considerar que a massa Polar Atlântica, após o solstício de verão, atravessa o continente em processo de aquecimento bem mais intenso, além do enfraquecimento do abastecimento de ar polar, o que implica no fato de que suas propriedades sejam consideravelmente diferentes daquelas observadas no decorrer do inverno (MONTEIRO, 1973). A fase de domínio é marcada, ainda, por forte nebulosidade, reduzida amplitude térmica e ventos predominantes do quadrante SE, oriundos do anticiclone Polar.

A massa de ar polar que dominou o tempo sobre a região começa a se modificar em virtude de seu avanço para latitudes mais baixas e pelo tempo de permanência em contato com a superfície do continente que favorece o aquecimento basal, entrando em processo de tropicalização (Massa Polar Velha ou Tropicalizada). Essa fase é marcada pela dissipação da nebulosidade, aumento gradativo da temperatura do ar e da amplitude térmica diária. A fase de tropicalização marca o fim do domínio da massa Polar Atlântica e a retomada do domínio da massa Tropical no cenário atmosférico na região, dando início a um novo ciclo.

Assim, a seqüência dessas fases traduz os tipos de tempo habituais do período de verão na região de São Carlos, podendo variar de acordo com a freqüência, a intensidade e a duração dos sistemas atmosféricos dominantes na região.

Por fim, salienta-se que o conhecimento do comportamento habitual de cada de tipo de tempo permite definir episódios representativos do fato climático e, por meio deles, delinear mais precisamente a verdade das condições climáticas e a representatividade de sua repercussão no comportamento do campo térmico urbano. 


\section{Capítulo III}

\section{PROCEDIMENTOS METODOLÓGICOS}

Os procedimentos metodológicos adotados no desenvolvimento da presente investigação compreenderam quatro etapas distintas, desenvolvidas de forma seqüencial. A primeira etapa consistiu no levantamento de dados na forma conceitualteórica por meio de pesquisa bibliográfica, a qual fundamenta a primeira parte deste trabalho. Nessa etapa, procurou abordar aspectos teóricos sobre o ambiente urbano como modificador das condições iniciais do clima, resultando num clima peculiar denominado clima urbano; o balanço energético resultante do sistema cidadeatmosfera e sua implicação da conformação do campo térmico urbano e na formação de ilhas de calor; e, por fim, a caracterização de São Carlos, que permitiu traçar perfil do ecossistema de estudo da investigação experimental. Essa etapa abarcou, ainda, o conhecimento das características climáticas de São Carlos, por meio da abordagem dinâmica do clima, caracterizando e identificando os tipos de tempo habituais do período de verão, com fito de subsidiar a escolha de episódio representativo do fato climático para a investigação em tela.

A segunda etapa consistiu na aquisição de registros climáticos contínuos em superfície por meio de estações automáticas instaladas em diferentes áreas da malha urbana de São Carlos, com características diferenciadas do sítio urbano e do entorno construído, ao tempo que a terceira etapa consistiu na definição do período de análise, com vistas a identificar episódios representativos do fato climático de verão, de forma a alcançar melhor precisão e representatividade dos resultados obtidos por meio de investigação experimental.

Por fim, a quarta e última etapa consistiu na análise e discussão dos resultados obtidos, com vistas a conhecer o comportamento do campo térmico da cidade de São Carlos em sua dimensão temporal, com vistas a identificar indícios de formação de ilhas de calor urbano nos diferentes tipos de tempo de um episódio climático de verão.

Os procedimentos metodológicos da investigação experimental foram descritos a seguir. 


\section{AQUISIÇÃO DE REGISTROS CLIMÁTICOS EM SUPERFÍCIE}

Os registros climáticos em superfície foram provenientes de quatro estações automáticas instaladas na malha urbana de São Carlos, com registros de dados climáticos contínuos e ininterruptos, com registros totalizados em média a cada 30 minutos. As estações usadas como parâmetros do comportamento climático em área urbana foram instaladas no Campus I e no Campus II da Escola de Engenharia de São Carlos, da Universidade de São Paulo; na Faculdade de Direito de São Carlos Fadisc; e no conjunto residencial Samambaia.

As estações localizam-se em bairros distintos, em diferentes cotas altimétricas e com distintos padrões de uso e ocupação do solo, constituindo-se, desta forma, em registro de dados representativos para análise espacial no qual considere a topografia do sítio e a ocupação do solo urbano. A Figura 10a mostra a localização das quatro estações automáticas na malha urbana de São Carlos sobre modelo digital de terreno, evidenciando a conformação do revelo na cidade com indicação das diferentes altitudes em cada estação climática, enquanto a Figura 10b mostra o perfil topográfico transversal da área urbana de São Carlos com a localização das quatro estações climáticas adotadas na presente investigação experimental.

a)

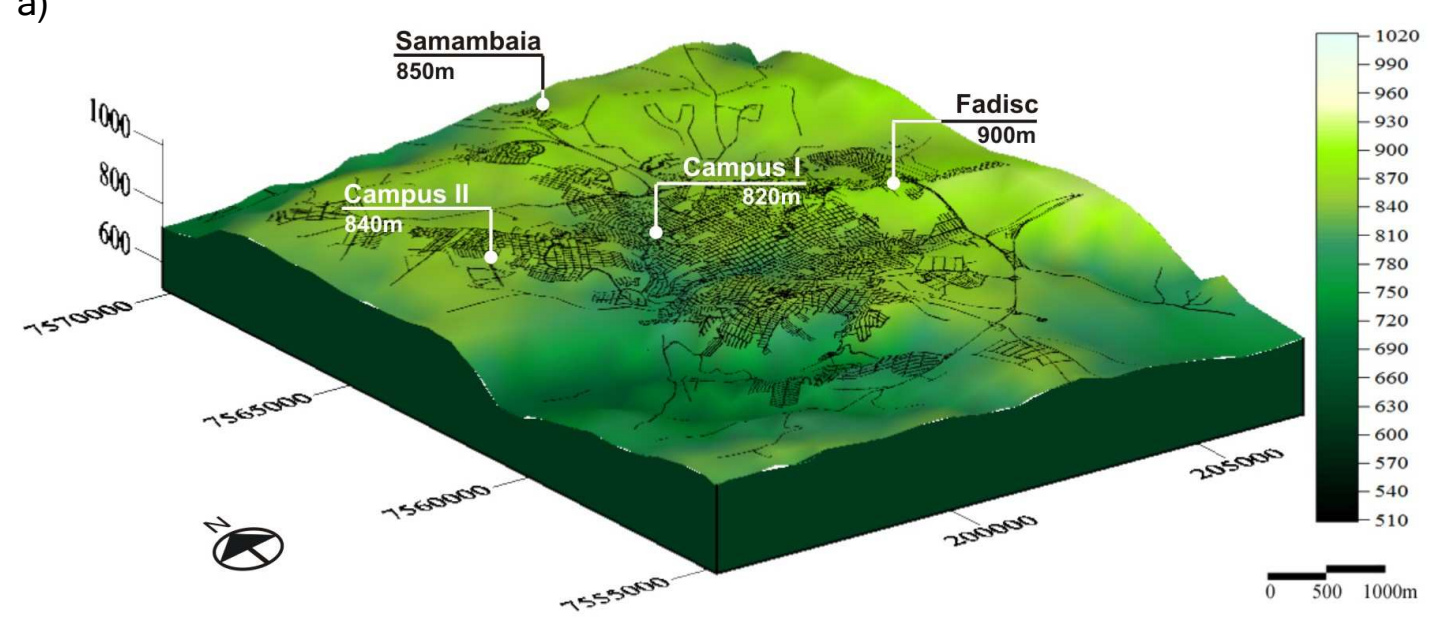

b)

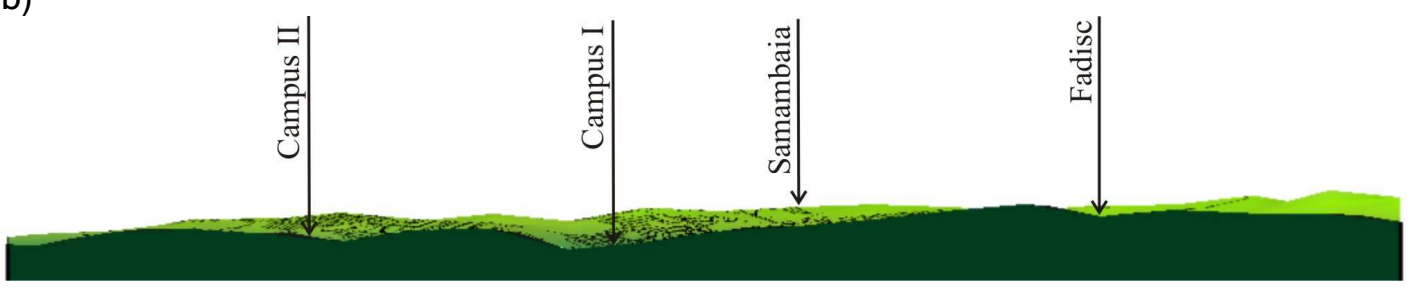

Figura 10: (a) Localização das quatro estações automáticas na malha urbana de São Carlos sobre modelo digital de terreno, mostrando a conformação do revelo na cidade com indicação das diferentes altitudes em cada estação climática; (b) perfil topográfico transversal da área urbana de São Carlos com a localização das quatro estações climáticas adotadas na presente investigação experimental. 
As estações adotadas na presente investigação são provenientes de projetos distintos de grupos de pesquisa da Escola de Engenharia de São Carlos, Universidade de São Paulo, a serem mencionados a seguir. Os dados foram cedidos para a pesquisa em tela, sendo posteriormente compilados e tratados pelo autor da presente pesquisa. As características do entorno e dos equipamentos foram descritos a seguir.

\subsection{Estações climáticas usadas na aquisição de dados em superfície}

\section{- Estação no Campus I}

A estação automática no Campus I da Escola de Engenharia de São Carlos foi instalada próximo ao Laboratório de Construção Civil - LCC, margeando a avenida Trabalhador São-carlense, no bairro Arnold Schimidt.

A estação localiza-se na porção central da cidade, com cota altimétrica de 820 $\mathrm{m}$, situada em fundo de vale. Dista, aproximadamente, $3 \mathrm{~km}$, em linha reta, na direção sudeste da estação no Campus II; 4 km na direção oeste da estação na Fadisc; e 5,5 km na direção sul da estação no Samambaia. Seu entorno construído é caracterizado pelo uso misto do solo, com residências, pontos comerciais e institucional (o próprio Campus da Universidade de São Paulo). Apresenta área densamente construída, com a presença de alguns prédios baixos e outros com mais de dez pavimentos, além de pouca vegetação arbórea. A cobertura do solo é predominantemente asfáltica, com reduzidas áreas de solo vegetado. O padrão habitacional é predominantemente alto, com densidade populacional entre 50 a 100 hab/ha (PMSC, 2004). A Figura 11a mostra a localização da estação no Campus I na área urbana de São Carlos, ao tempo que a Figura 11b evidencia o entorno construído da área.

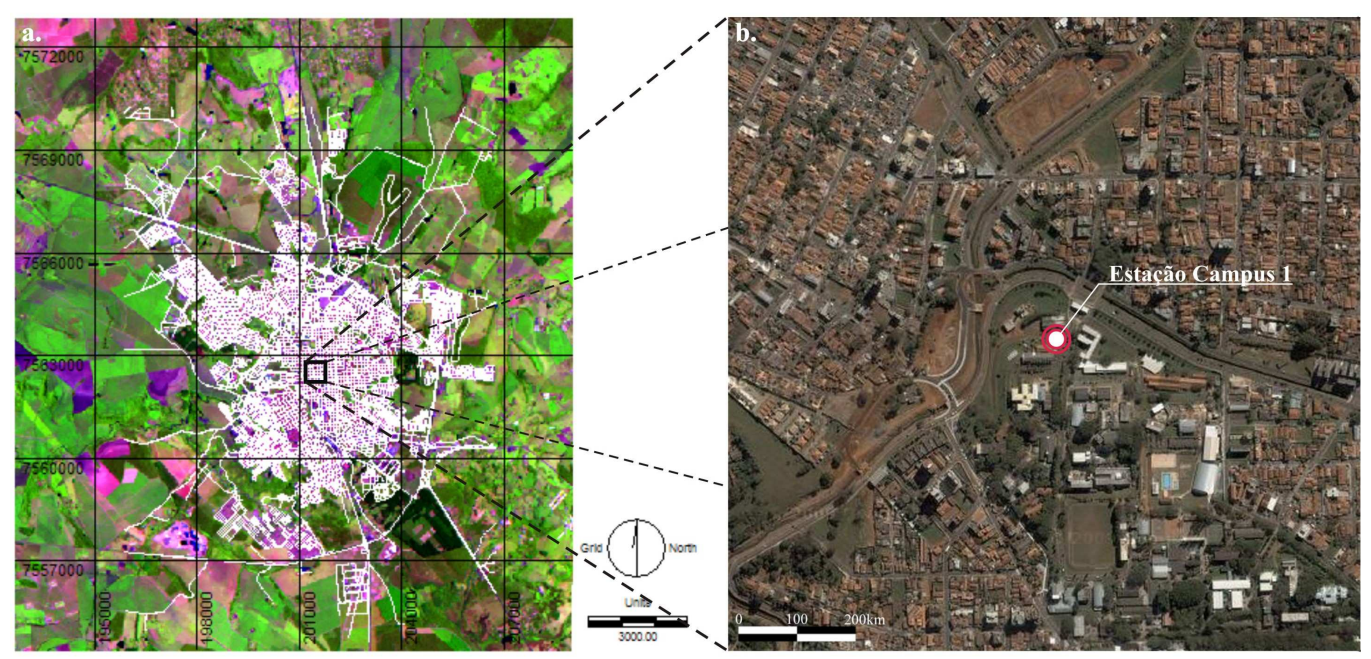

Figura 11: (a) Localização da estação Campus I na área urbana de São Carlos e (b) entorno da estação Campus I.

Fonte: (a) PMSC, 2004 e (b) Google Maps, 2009. 
A Figura 12 evidencia o entorno construído na área do Campus I. A Figura 12a e a Figura $12 \mathrm{~b}$ dão destaque à densidade de construção e à verticalização das construções, além do predomínio pavimentação asfáltica no entorno. A Figura $12 \mathrm{c}$ evidencia a densidade de construção e extensa área de solo pavimentado dentro do Campus I, ao tempo que a Figura 12d mostra o córrego canalizado junto a avenida Trabalhador San-carlense, no entorno do Campus I.

a)

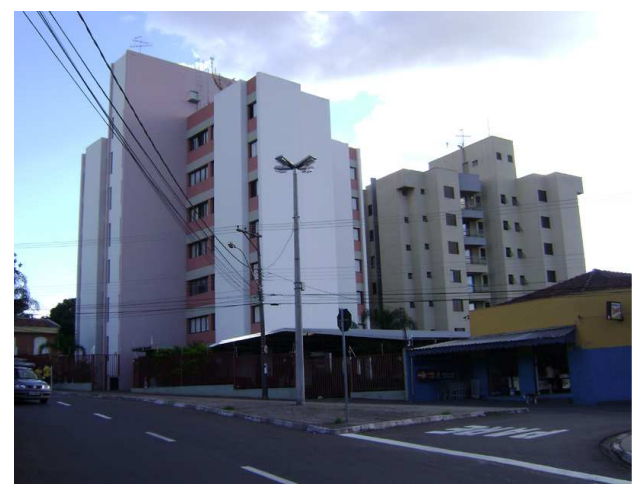

c)

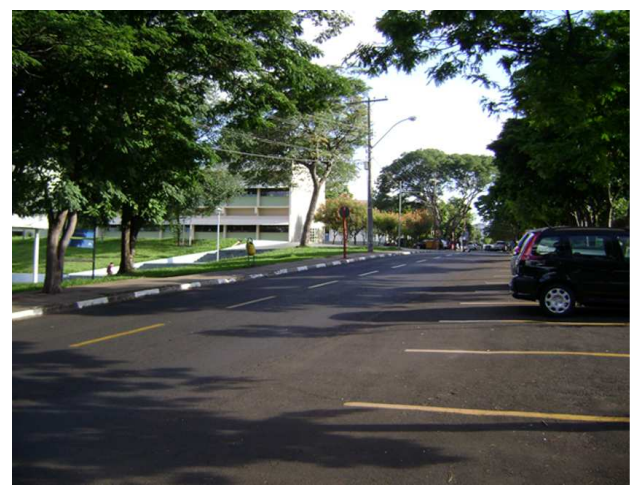

b)

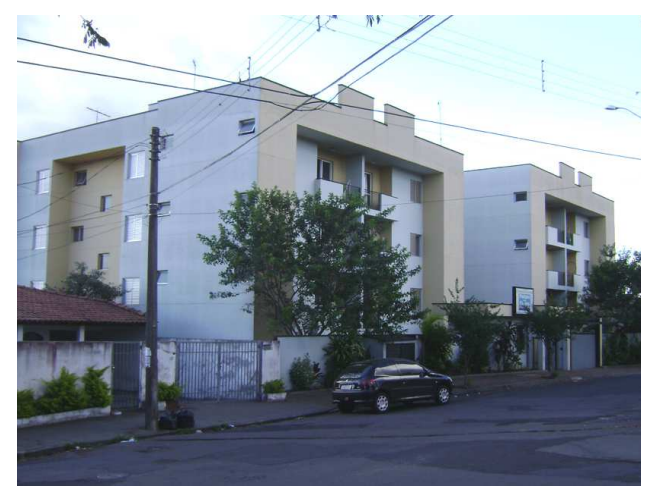

d)

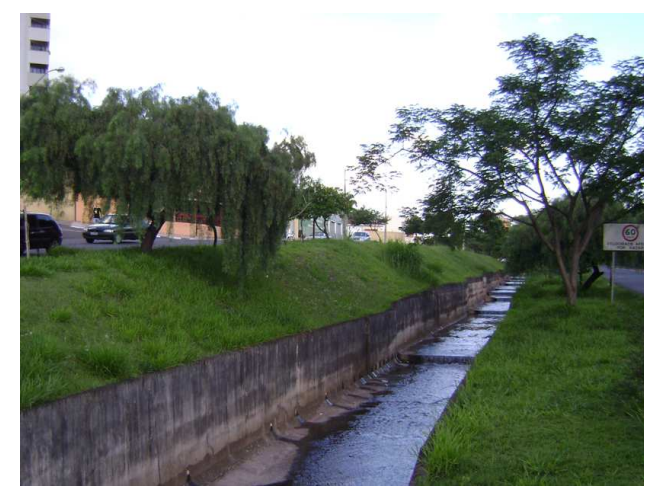

Figura 12: (a)(b) Entorno construído na área do Campus I, com destaque para a densidade de construção e verticalização das construções; (c) densidade de construção e extensa área de solo pavimentado no Campus I da Escola de Engenharia de São Carlos, Universidade de São Paulo; e (d) córrego canalizado no entorno do Campus I.

Fonte: o autor, 30 out. 2009.

Quanto às características do equipamento, a referida estação trata-se de equipamento Campbell provido de sensores para registro de dados de temperatura do $\operatorname{ar}\left({ }^{\circ} \mathrm{C}\right)$, umidade relativa do $\operatorname{ar}(\%)$, radiação solar $\left(\mathrm{W} / \mathrm{m}^{2}\right)$, velocidade média ${ }^{12}$ do vento a $3 \mathrm{~m}$ solo $(\mathrm{m} / \mathrm{s})$, momento da velocidade máxima do vento $(\mathrm{h})$, direção do vento $(0-$ $360^{\circ}$ ) e precipitação total $(\mathrm{mm})$. Os dados foram registrados em médias aritméticas de intervalos de 30 minutos, totalizando 48 registros diários.

\footnotetext{
${ }^{12} \mathrm{O}$ registro do valor médio da velocidade do ar é a média aritmética dos valores de velocidade do ar em intervalos de 30 minutos.
} 


\section{- Estação no Campus II}

A estação automática no Campus II da Escola de Engenharia de São Carlos foi instalada próxima ao Centro de Apoio Técnico - CAT e se presta ao monitoramento ambiental do Campus II, requisitado pelo Departamento Estadual de Proteção de Recursos Naturais - DEPRN, de São Carlos, e firmado em Termo de Compromisso de Recuperação Ambiental - TCRA, em função do licenciamento para implantação do referido Campus nesta área.

A estação localiza-se na porção Oeste da cidade, com cota altimétrica de 840 m. Dista, aproximadamente, $3 \mathrm{~km}$, em linha reta, na direção noroeste da estação no Campus I; 7 km na direção oeste da estação na Fadisc; e 6,6 km na direção sudoeste da estação no Samambaia. Seu entorno construído é caracterizado pelo uso do solo predominantemente residencial, com alguns poucos pontos de comércio e serviço local, além do uso institucional (o próprio Campus da Universidade de São Paulo).

A área apresenta densidade de construção moderada, com predomínio de edificações térreas sem recuo em lotes estreitos. As vias de circulação apresentam leito carroçável largo e grandes espaços abertos, embora sem presença de vegetação arbórea. A cobertura do solo é predominantemente asfáltica, com extensas áreas de solo nú. O padrão habitacional é predominantemente baixo, com densidade populacional entre 50 a 100 hab/ha (PMSC, 2004). A Figura 13a mostra a localização da estação no Campus II na área urbana de São Carlos, ao tempo que a Figura 13b evidencia o entorno construído da área.

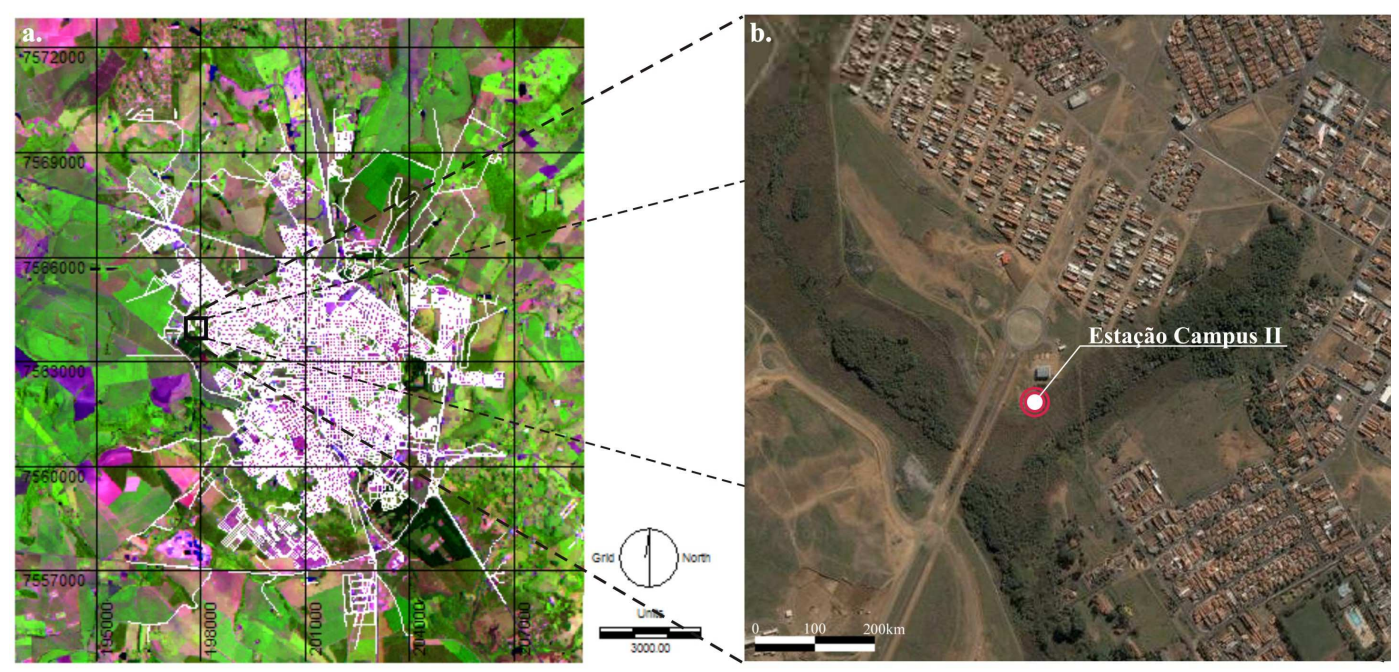

Figura 13: (a) Localização da estação Campus II na área urbana de São Carlos e (b) entorno da estação Campus II.

Fonte: (a) PMSC, 2004 e (b) Google Maps, 2009. 
A Figura 14 evidencia o entorno construído na área do Campus II. A Figura 14a e a Figura 14b evidenciam o predomínio de edificações térreas, sem recuo e em lotes estreitos, ao tempo que a Figura 14c destaca as extensas áreas abertas sem presença de vegetação arbórea, além do largo leito carroçável com baixo fluxo de veículos. A Figura 14d mostra a baixa densidade de construção no Campus II, com extensa área de solo gramado.

a)

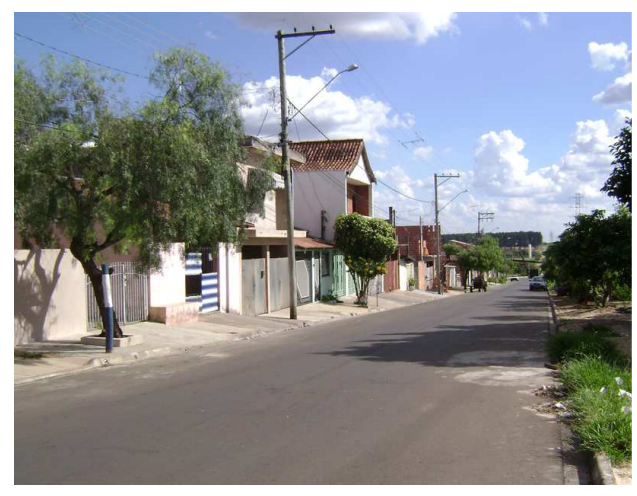

c)

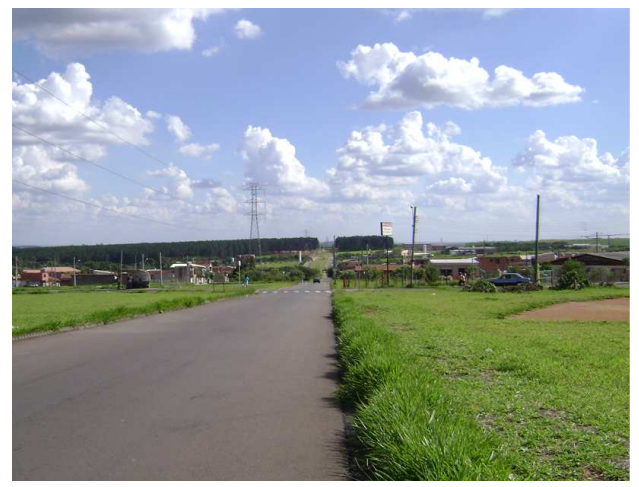

b)

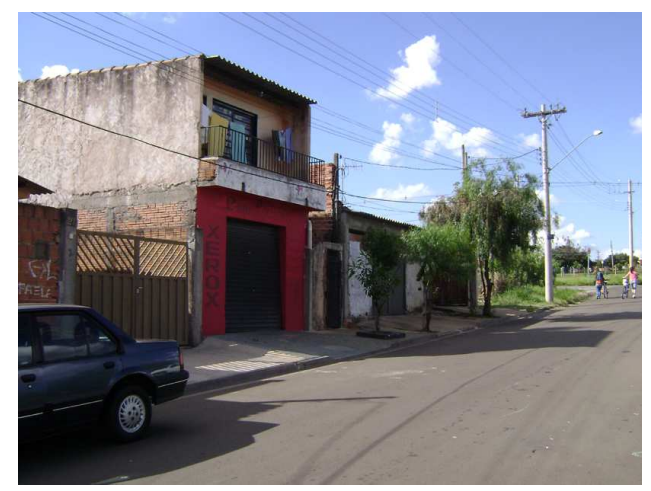

d)

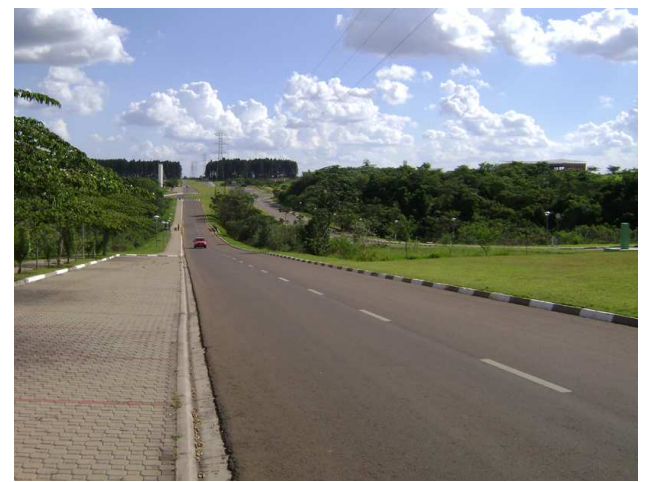

Figura 14: (a)(b) Entorno construído na área do Campus II evidenciando o predomínio de edificações térreas, sem recuo em lotes estreitos; (c) extensas áreas abertas sem presença de vegetação arbórea; e (d) a baixa densidade de construção no Campus II, com extensa área de solo gramado.

Fonte: o autor, 30 out. 2009.

Quanto às características do equipamento, a referida estação trata-se de equipamento Campbell provido de sensores para registro de dados de temperatura do ar $\left({ }^{\circ} \mathrm{C}\right)$, umidade relativa do ar $(\%)$, radiação solar $\left(\mathrm{W} / \mathrm{m}^{2}\right)$, pressão atmosférica $(\mathrm{mm})$, temperatura do solo $\left({ }^{\circ} \mathrm{C}\right)$, umidade do solo $\left({ }^{\circ} \mathrm{C}\right)$, velocidade do vento a $3 \mathrm{~m}$ solo $(\mathrm{km} / \mathrm{h})$, direção do vento $\left(0-360^{\circ}\right)$ e precipitação total $(\mathrm{mm})$. Os dados foram registrados em intervalos de 5 minutos, totalizando 288 registros diários. Entretanto, os mesmos foram tabulados em médias aritméticas em intervalos de 30 minutos, com vistas à confrontação desses dados com registros tomados nas demais estações. 


\section{- Estação na Fadisc}

A referida estação automática foi instalada nas proximidades da Faculdade de Direito de São Carlos - Fadisc, no bairro Vila Nery, numa das regiões mais elevadas do perímetro urbano de São Carlos. A mesma faz parte do projeto Experimento Piloto de Gerenciamento Integrado de Bacias Urbanas para o Plano Diretor do Município de São Carlos-SP(FINEP, 2002).

A estação localiza-se na porção Leste da cidade, em cota altimétrica de $900 \mathrm{~m}$. Dista, aproximadamente, 4 km, em linha reta, na direção leste da estação no Campus I; 7 km na direção sudeste da estação no Campus II; e 7 km na direção sul da estação no Samambaia. Seu entorno construído é caracterizado pelo uso do solo predominantemente residencial, além do uso institucional (a própria Faculdade de Direito de São Carlos).

A área apresenta baixa densidade de construção, circundada por condomínios fechados de alto padrão habitacional e extensa área de vegetação arbórea. A cobertura do solo é predominantemente gramínea e vias de circulação com leito asfaltado. A densidade populacional é menor que 50 hab/ha (PMSC, 2004). A Figura 15a mostra a localização da estação na Fadisc na área urbana de São Carlos, ao tempo que a Figura 15b evidencia o entorno construído da área.

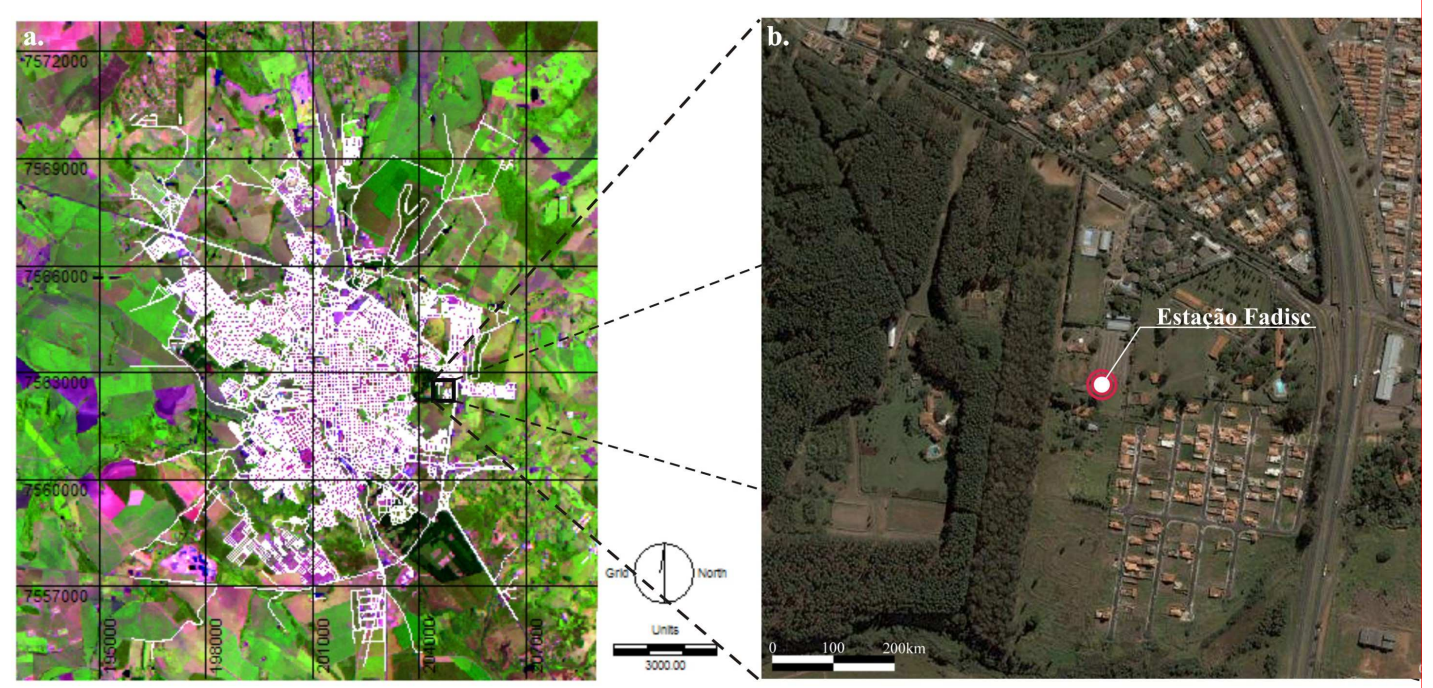

Figura 15: (a) Localização da estação Fadisc na área urbana de São Carlos e (b) entorno da estação Fadisc.

Fonte: (a) PMSC, 2004 e (b) Google Maps, 2009.

A Figura 16 evidencia o entorno construído na área da Fadisc. A Figura 16a e Figura 16b mostram a baixa densidade de construção, com grande número de lotes vazios, além da altitude da área no revelo de São Carlos. A Figura 16c e Figura 16d 
dão destaque à extensa área verde com vegetação arbórea que circunda a área da Fadisc.

a)

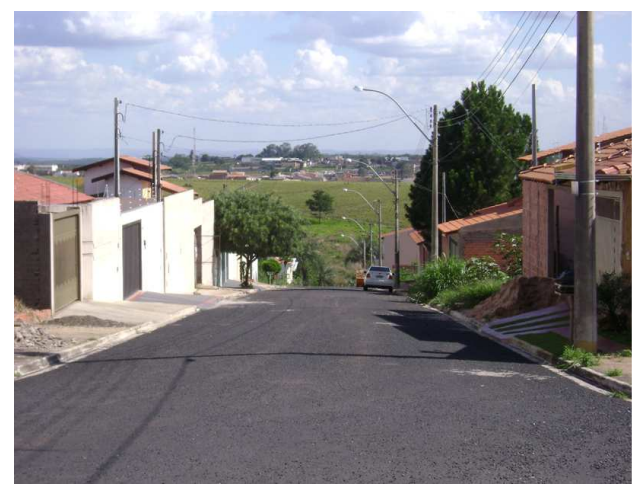

c)

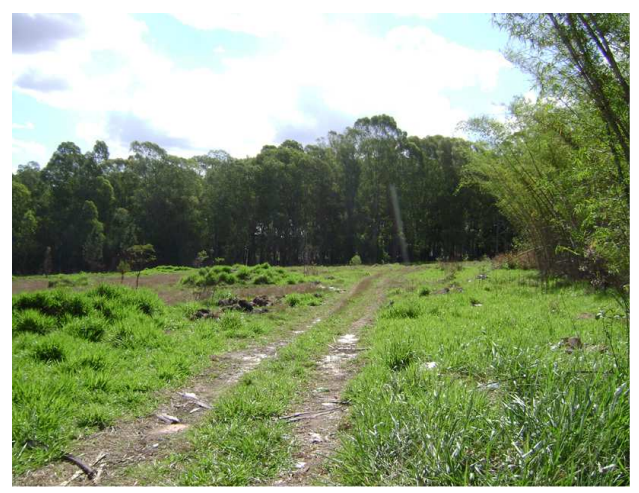

b)

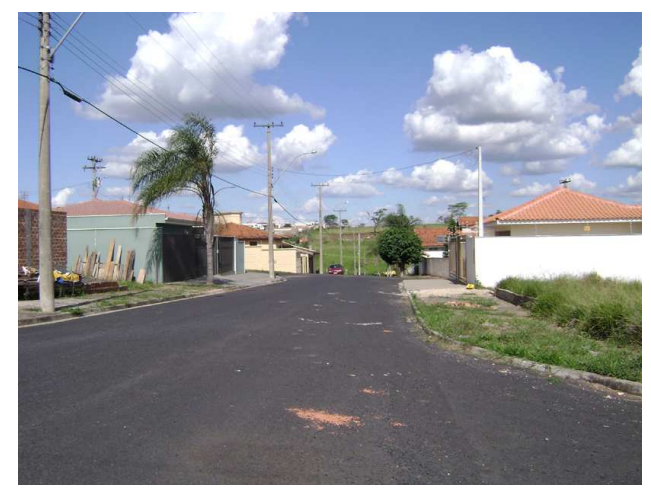

d)

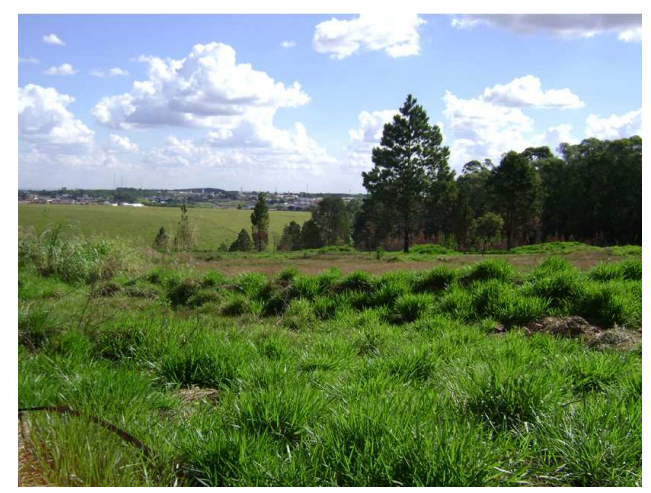

Figura 16: (a) (b) Entorno construído na área da Fadisc, com destaque para a baixa densidade de construção, com grande número de lotes vazios. As figuras evidenciam, ainda, a altitude da área no relevo de São Carlos. (c) (d) Extensa área verde com vegetação arbórea que circunda a área da Fadisc.

Fonte: o autor, 30 out. 2009.

Quanto às características do equipamento, a referida estação trata-se de equipamento Campbell provido de sensores para registro de dados de temperatura do $\operatorname{ar}\left({ }^{\circ} \mathrm{C}\right)$, umidade relativa do ar $(\%)$, radiação solar $\left(\mathrm{W} / \mathrm{m}^{2}\right)$, radiação de referência e pressão atmosférica $(\mathrm{mmHg})$. Assim como a estação no Campus I, os dados foram registrados em médias de intervalos de 30 minutos, totalizando 48 registros diários. 


\section{- Estação no Samambaia}

A estação localiza-se na porção Norte da cidade, em cota altimétrica de $850 \mathrm{~m}$. Dista, aproximadamente, $5,5 \mathrm{~km}$, em linha reta, na direção norte da estação no Campus I; 6,6 km em direção nordeste da estação no Campus II; e 7 km em direção noroeste da estação na Fadisc.

Seu entorno construído é caracterizado pelo uso do solo residencial, situandose em condomínio fechado e afastado do centro urbano. A área apresenta densidade de construção baixa e alto padrão habitacional. O condomínio residencial Samambaia possui áreas verdes em seu interior e está circundado por extensa área de vegetação arbórea. A cobertura do solo é predominantemente asfáltica. Informações sobre densidade populacional não foi encontrada, mas estima-se que seja menor que 50 hab/ha. A Figura 17a mostra a localização da estação na Fadisc na área urbana de São Carlos, ao tempo que a Figura 17b evidencia o entorno construído da área.

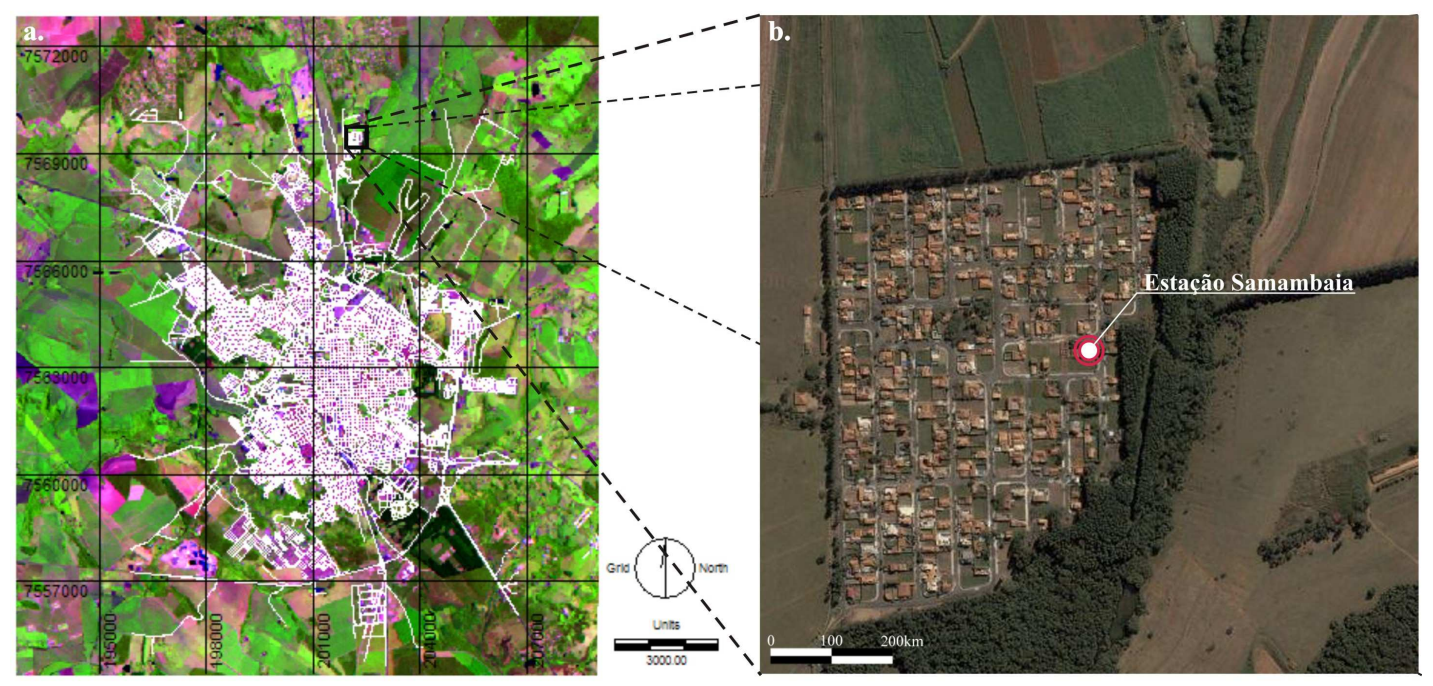

Figura 17: (a) Localização da estação Samambaia na área urbana de São Carlos e (b) entorno da estação Samambaia.

Fonte: (a) PMSC, 2004 e (b) Google Maps, 2009.

A Figura 18 evidencia o entorno construído na área do condomínio residencial Samambaia. A Figura 18a, a Figura 18b e a Figura 18c evidenciam a baixa densidade de construção e para a vegetação arbórea nas ruas, ao tempo que a Figura 18d destaca a extensa área verde com vegetação arbórea que circunda a área da do condomínio residencial Samambaia. 
a)

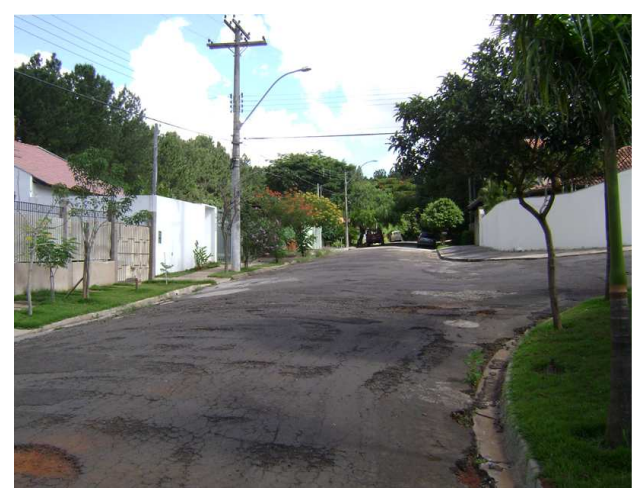

c)

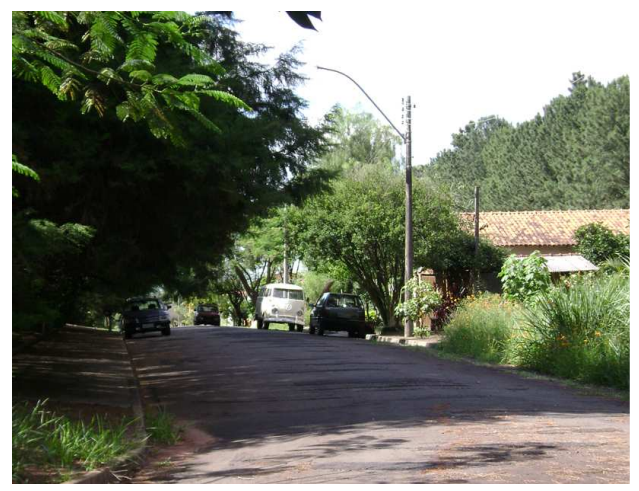

b)

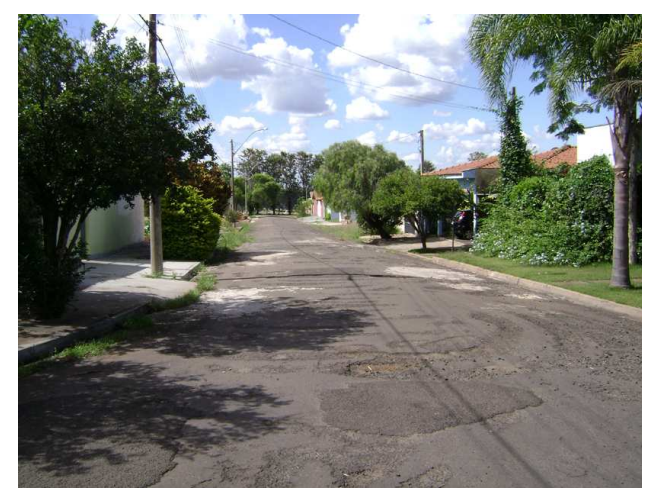

d)

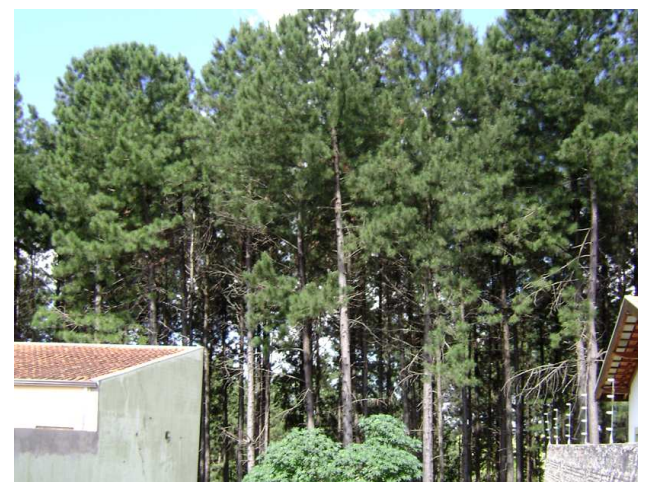

Figura 18: (a) (b) (c) Entorno construído na área do condomínio residencial Samambaia, com destaque para a baixa densidade de construção e para a vegetação arbórea nas ruas. (d) Extensa área verde com vegetação arbórea que circunda a área da do condomínio residencial Samambaia.

Fonte: o autor, 30 out. 2009.

Quanto às características do equipamento, a estação automática instalada no Condomínio Residencial Samambaia trata-se de equipamento Davis, modelo Vantage Pro2 Wireless, versão Plus, com conjunto de sensores integrados (ISS), caracterizando-se, assim, como a única estação diferente. É provida de sensores para registro de dados de temperatura do $\operatorname{ar}\left({ }^{\circ} \mathrm{C}\right)$, radiação solar $\left(\mathrm{W} / \mathrm{m}^{2}\right)$ e precipitação total $(\mathrm{mm})$. Os dados foram registrados em intervalos de 5 minutos, totalizando 288 registros diários. Entretanto, assim como na estação no Campus II, os dados foram tabulados em médias aritméticas em intervalos de 30 minutos, com vistas à confrontação desses dados com registros tomados nas demais estações.

\subsection{Organização e tratamento dos dados climáticos}

Os dados climáticos provenientes das quatro estações automáticas descritas anteriormente foram, inicialmente, compilados por estações automáticas em tabelas distintas, a partir das quais foi feito levantamento dos dados disponíveis e passíveis de serem usados para o propósito da presente pesquisa. 
O resultado do levantamento efetuado serviu de base para a formulação de quadro-síntese, no qual foram representados graficamente os períodos de dados existentes em cada estação automática. Dessa forma, o quadro-síntese, apresentado a seguir, permitiu a identificação dos períodos nos quais havia disponíveis dados climáticos concomitantes nas quatro estações automáticas existentes na malha urbana.

Quadro 2: Quadro-síntese dos dados disponíveis nas cinco estações automáticas no período de verão (novembro/04 a março/05)

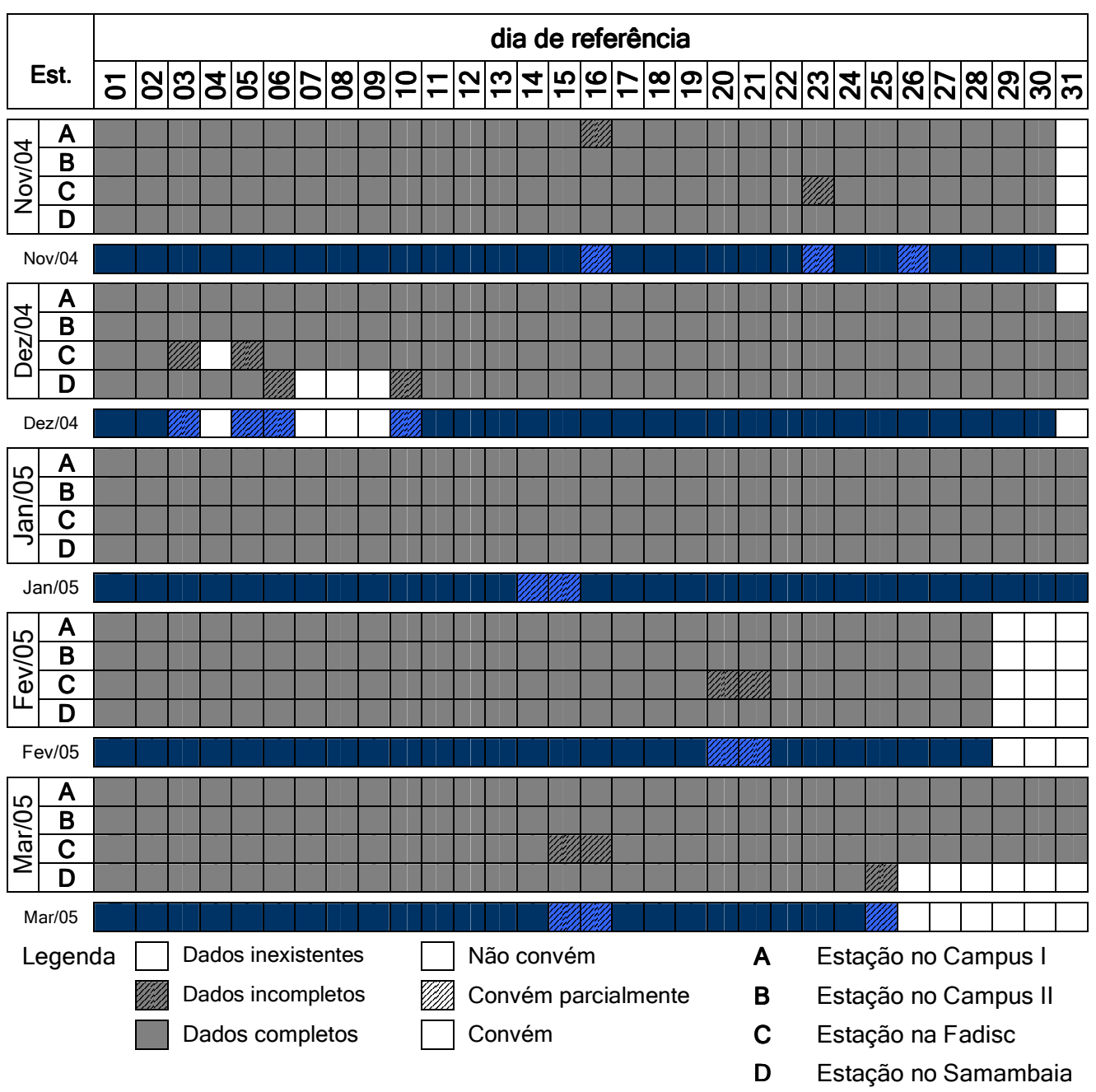

O quadro-síntese evidenciou que os dados climáticos existentes e disponíveis para análise no período do verão de 2004/2005 apresentavam poucas interrupções, com exceção do dia 04/12/2004, o período entre os dias 07 a 09/12/2004 e o dia $31 / 12 / 2004$ que não convinha à análise visto que, pelo menos uma das quatro estações, apresentava dados inexistentes. Nos demais dias, o requisito de dados 
climáticos concomitantes nas quatro estações automáticas foi atendido de forma satisfatória.

Após o levantamento dos dados climáticos e a análise dos períodos possíveis para a investigação experimental, fez-se necessário definir um episódio representativo do fato climático de verão para análise nas diferenças térmicas entre os dados registrados nas estações localizadas nas áreas urbanas, o que constituiu a terceira etapa da investigação experimental.

\section{DEFINIÇÃO DE UM EPISÓDIO CLIMÁTICO REPRESENTATIVO DO PERÍODO DE VERÃO}

Frente a gama de possíveis períodos de observação e de análise evidenciados no quadro-síntese (Quadro 2), foi necessário identificar um episódio que delineasse mais precisamente a verdade das condições climáticas pela sua representatividade e resolução, aplicando-se, dessa forma, como instrumento válido de avaliação.

Nesse sentido, optou-se por delimitar episódio climático que atendesse a dois critérios básicos: (a) contivesse dentro do período de observação um dia de extremo rigor térmico, com temperatura do ar acima da média das máximas indicada pelas Normais Climatológicas ${ }^{13}$ (BRASIL, 1992) para o período de verão; e (b) apresentasse encadeamento habitual de tipos de tempo do período de verão.

Dessa forma, foi feito estudo do ritmo climático para os meses de dezembro de 2004 , janeiro e fevereiro de 2005 , tendo como base os dados climáticos registrados na estação localizada no Campus I. A escolha pelos dados climáticos dessa estação para subsidiar a análise rítmica deu-se pelo fato de ser a única estação automática entre as quatro adotadas que dispunha de registros concomitantes de temperatura do ar, umidade relativa do ar, radiação solar global, pressão atmosférica, pluviosidade e direção e velocidade dos ventos. Esses dados foram fundamentais para a análise do ritmo climático na região, baseados na análise rítmica em Climatologia (Monteiro, $1971)^{14}$.

\footnotetext{
13 Ver Tabela 3: Normais Climatológicas de São Carlos - período 1961-1990.

${ }^{14}$ A análise rítmica é um método de análise diária dos elementos climáticos de um determinado local. Esse método foi desenvolvido pelo geógrafo Carlos Augusto de Figueiredo Monteiro, publicado em sua obra "Análise ritmica em Climatologia", em 1971. Consiste na análise de variáveis meteorológicas por meio de gráfico em escala diária. A análise ritmica é útil para comparação entre diferentes períodos, por meio dos quais é possível identificar anomalias climáticas e situações que podem ser classificadas como "habituais" para a área estudada.
} 
Por meio da análise rítmica, observou-se que o mês de fevereiro de 2005 apresentou-se mais adequado para a presente investigação, sobretudo por apresentar maior quantidade de dias com predominância de céu claro, menor total pluviométrico mensal e maior quantidade de dias com temperatura do ar próxima ou acima da média das máximas indicada pelas Normais Climatológicas (BRASIL, 1992).

Após definido o mês de fevereiro de 2005, foi feito o delineamento dos episódios climáticos ocorridos nesse mês, baseado no comportamento das variáveis meteorológicas e na sucessão dos diferentes tipos de tempo. Os resultados encontrados foram confrontados com as análises do Boletim Climanálise do Instituto de Pesquisas Espaciais - INPE (CLIMANÁLISE, 2005) para o referido mês, objetivando maior conhecimento da dinâmica dos sistemas frontais atuantes e validação dos episódios delineados.

A análise dos dados mostrou que, em fevereiro de 2005, cinco sistemas frontais atuaram sobre a região de São Carlos. O Climanálise (2005) informou que as frentes frias que atuaram ao longo desse mês foram de fraca intensidade, causando nebulosidade e chuva fraca, fato que também pode ser observado por meio da análise dos gráficos adaptados da análise rítmica preconizada por Monteiro (1971), como mostra o Gráfico 2.

A partir da identificação e delineamento dos cinco episódios climáticos ocorridos no mês de fevereiro, optou-se por definir o quinto episódio, cujo avanço do sistema frontal sobre a região de São Carlos ocorreu no dia 25/02/2005, como representativo para a análise do campo térmico urbano. Os fatores que levaram à escolha desse episódio climático pautaram-se nos dois critérios deliberados anteriormente. Nesse sentido, o episódio climático compreendido entre os dias 20/02/2005 e 01/03/2005 continha em seu período de observação dias de forte rigor térmico, com temperatura do ar acima da média das máximas indicada pelas Normais Climatológicas, conforme pode ser observado no Gráfico 1.

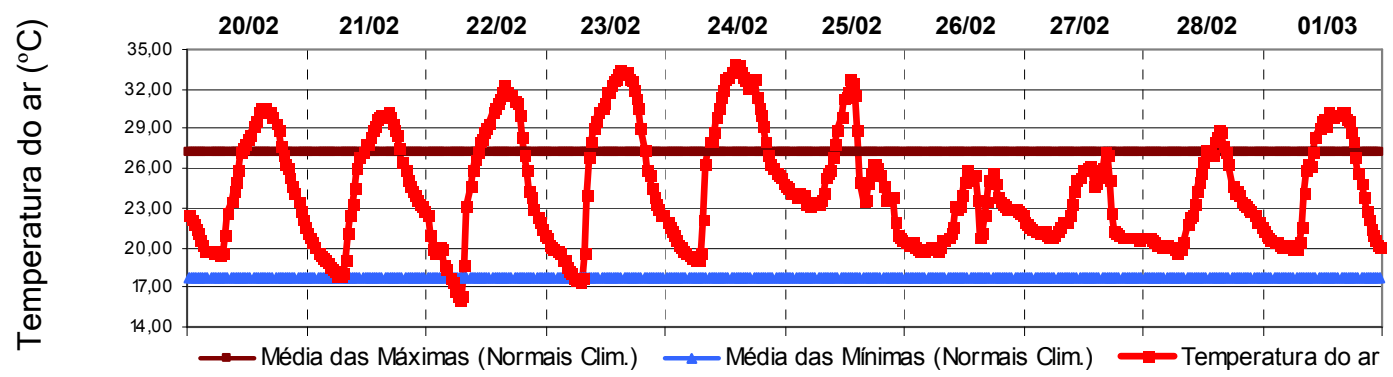

Gráfico 1: Comportamento da temperatura do ar na cidade de São Carlos entre os dias 20/02/2005 e 01/03/2005, com indicação da média das máximas e da média das mínimas para o mês de fevereiro fornecidas pelas Normais Climatológicas de 1961-1990. 

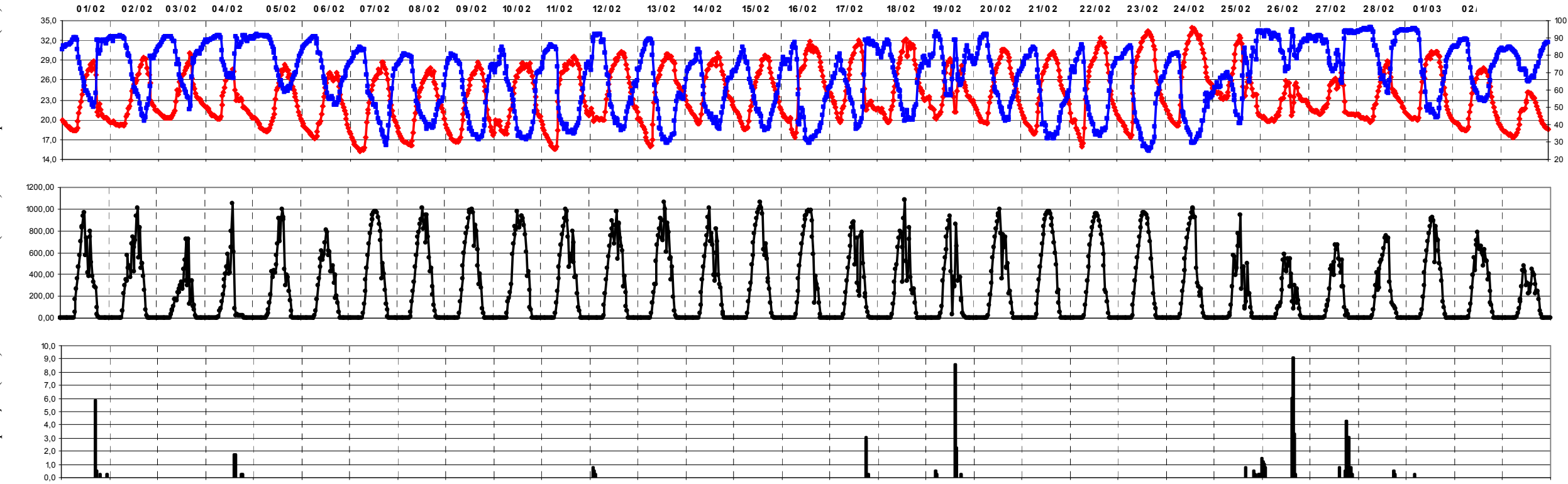

$$
\text { ind }
$$

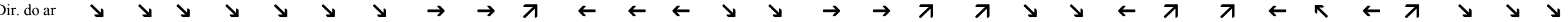

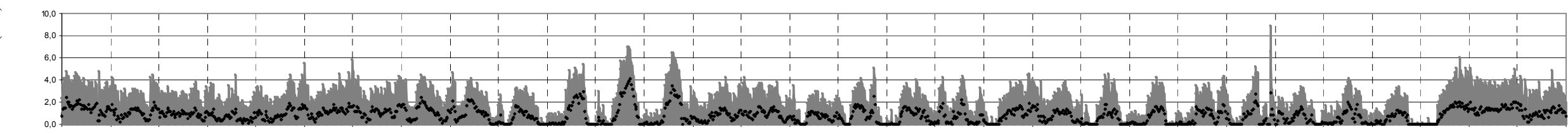

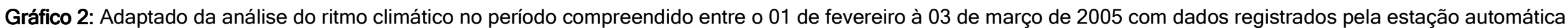
localizada no Centro de Recursos Hídricos e Ecologia Aplicada - CRHEA. 
Destaca-se, ainda, que o dia 24/02/2005 foi o dia mais quente do verão analisado $^{15}$ (máxima absoluta de $34^{\circ} \mathrm{C}$ ) e o comportamento das variáveis meteorológicas entre os dias 20/02/2005 e 01/03/2005 corresponderem ao encadeamento habitual de tipos de tempo no período de verão, conforme descrito no item 3.3 desta tese, caracterizando-o, assim, como um episódio representativo e, portanto, válido como instrumento de análise para a investigação em tela.
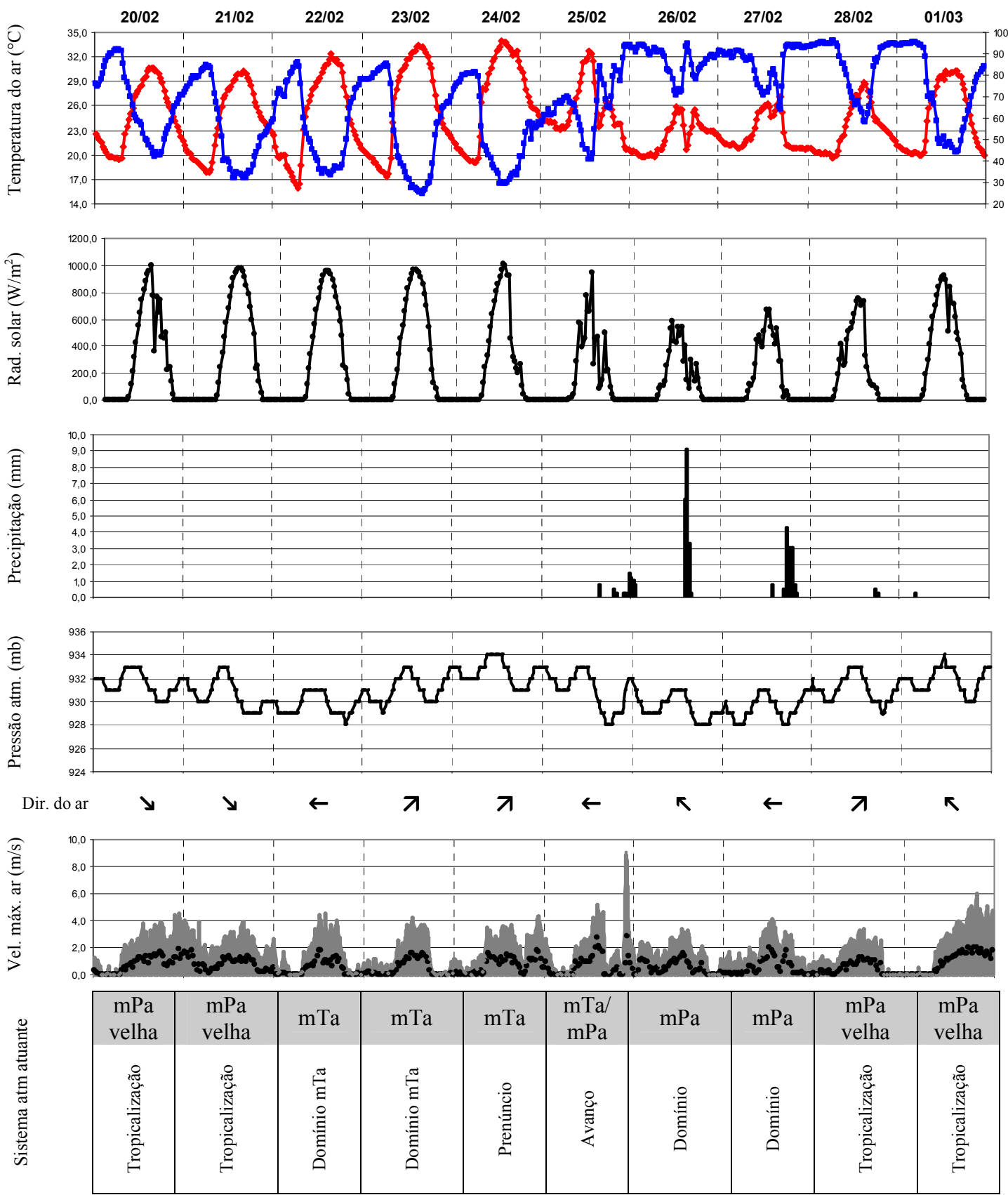

Figura 19: Análise rítmica do episódio climático delineado compreendido entre os dias 20 de fevereiro a 01 de março de 2005 com indicação do sistema atmosférico atuante.

${ }^{15}$ Considerando os dados da estação tomada como referência para a presente investigação. 
Salienta-se, por fim, que foi tomando como início um tipo de tempo característico da fase de tropicalização, finalizando o período delineado com o mesmo tipo de tempo, de forma a analisar um ciclo completo. 


\section{Capítulo IV}

\section{ANÁLISE E DISCUSSÃO DOS RESULTADOS OBTIDOS}

Após a definição do episódio representativo do fato climático de verão para São Carlos, foi feita a análise da intensidade do campo térmico urbano e das diferenças térmicas que sugerem a formação de ilhas de calor na cidade. O estudo do comportamento térmico diário foi feito ao longo de todo episódio climático nas quatro estações urbanas, com dados observados em intervalos de 30 minutos, o que permitiu maior precisão na análise e na discussão dos resultados obtidos.

A análise dos resultados foi precedida pela caracterização diária do cenário atmosférico em cada fase do episódio climático, expresso por meio da combinação dos diferentes elementos climáticos entre si, com fito de compreender a seqüência que conduz ao ritmo, como preconizado por Monteiro (1963). Nesse sentido, a análise e a discussão dos resultados foram apresentadas acompanhando o encadeamento habitual dos tipos de tempo expressos nas diferentes fases do episódio climático compreendido entre os dias 20/02/2005 e 01/03/2005.

\section{FASE DE TROPICALIZAÇÃO}

A fase de tropicalização compreendeu os dias 20 e 21/02/2005.

\section{- Dia 20 de fevereiro de 2005}

O dia 20/02/2005 apresentou amplitude térmica diária de $11,2^{\circ} \mathrm{C}$, com máxima de $30,6^{\circ} \mathrm{C}$, às $15: 00 \mathrm{~h}$, e mínima de $19,4^{\circ} \mathrm{C}$, às $7: 00 \mathrm{~h}$. Os índices de umidade relativa do ar foram elevados ao longo do dia, com registros superiores a $50 \%$ durante a madrugada até o início da tarde, apresentando-se abaixo dos $50 \%$ no período vespertino, com mínima de $42 \%$, às $15: 00$ h (horário em que foi registrada a temperatura máxima), voltando a elevar-se acima de $50 \%$ após o pôr-do-Sol.

O dia apresentou céu claro durante a manhã, o que favoreceu ao aquecimento das superfícies urbanas. A radiação solar global atingiu pico de $999 \mathrm{~W} / \mathrm{m}^{2}$, às 13:00h, com média diária de $271,2 \mathrm{~W} / \mathrm{m}^{2}$, ao longo de 13 horas de insolação. Entretanto, observou-se forte nebulosidade a partir das 16:00h, horário coincidente com o maior 
aquecimento do ar. A formação de nuvens nesse período possivelmente foi resultado por processo convectivo pela combinação entre elevada radiação solar direta, maior aquecimento da superfície e elevada umidade do ar, porém sem ocorrência de precipitação. A pressão atmosférica variou $3 \mathrm{mb}$, com pico de $933 \mathrm{mb}$, entre 9:30h e 12:30h, e mínima de 930mb, às 16:30h.

Os ventos predominantes foram do quadrante SE, o que sugere a presença da massa Polar Atlântica sobre a região, porém em fase de tropicalização. Durante o período matutino houve predomínio de aragem ${ }^{16}$. Nos períodos vespertino e noturno, os ventos foram um pouco mais intenso, variando entre brisa leve e brisa fraca, com velocidades inferiores a $4 \mathrm{~m} / \mathrm{s}$ e rajadas dos quadrantes S/SE.
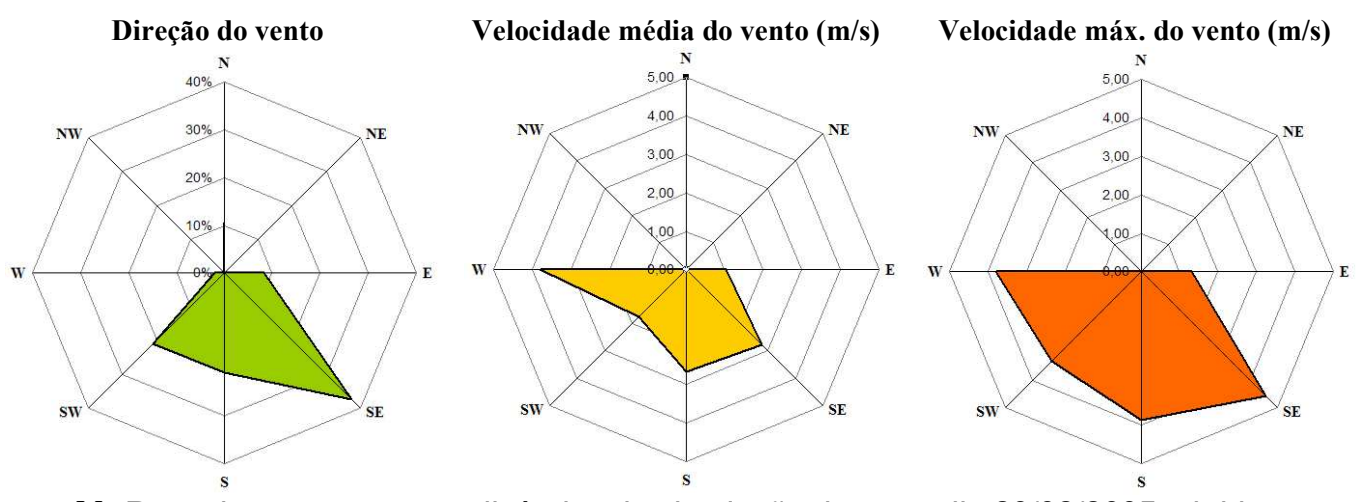

Figura 20: Rosa dos ventos com a dinâmica da circulação do ar no dia 20/02/2005, obtidos por meio de registros de direção e velocidade dos ventos tomados por média a cada 30 minutos pela estação automática localizada no Campus I.

Observou-se, assim, que o cenário atmosférico apresentou-se estável. A elevada umidade relativa do ar aliada a amplitude térmica estabilizada próxima aos $11^{\circ} \mathrm{C}$ e aos ventos predominantes do quadrante SE sugerem que a massa de ar sobre a região de São Carlos encontrava-se em processo de tropicalização, com céu parcialmente encoberto devido à elevada quantidade de vapor d'água na atmosfera.

As condições sinóticas do dia 20/02/2005 podem ser atestadas pela imagem do canal infravermelho do satélite GOES 12 e pela carta de pressão ao nível do mar (Figura 21), as quais mostram o deslocamento da Frente Polar Atlântica, que avançou sobre a região Sudeste no dia 17/02/2005, já sobre o Norte de Minas Gerais.

No dia 20/02/2005, o comportamento da temperatura do ar registrada nas quatro estações urbanas foi semelhante entre si, apresentando pequenas diferenças de valores ao longo do dia. O Gráfico 3 apresenta o comportamento da temperatura do ar em todas as estações analisadas.

\footnotetext{
${ }^{16}$ De acordo com a escala de Beaufort (ver anexo II).
} 
(a)

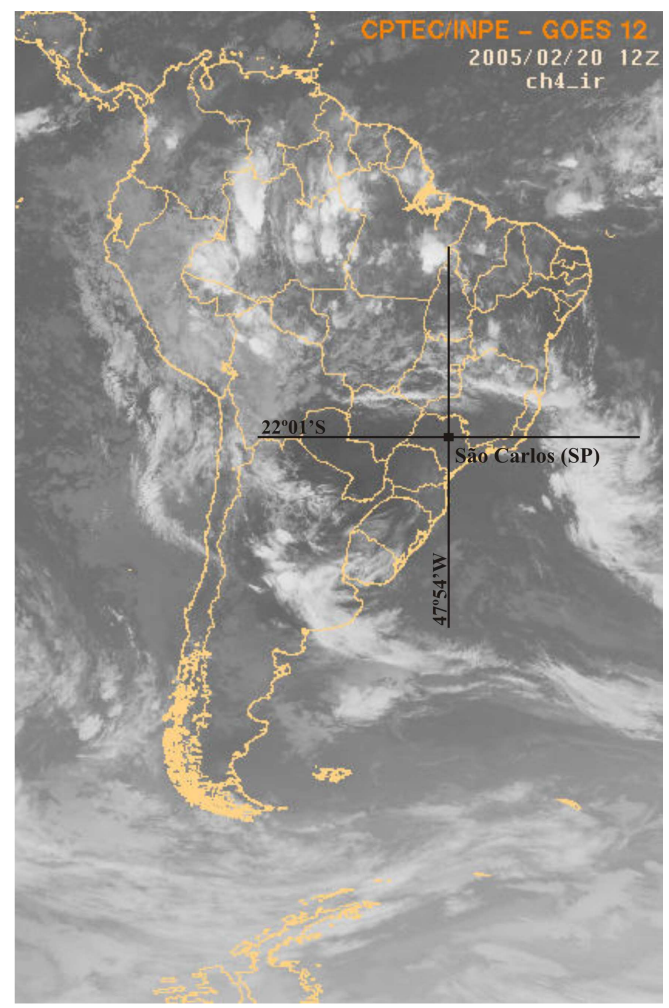

(b)

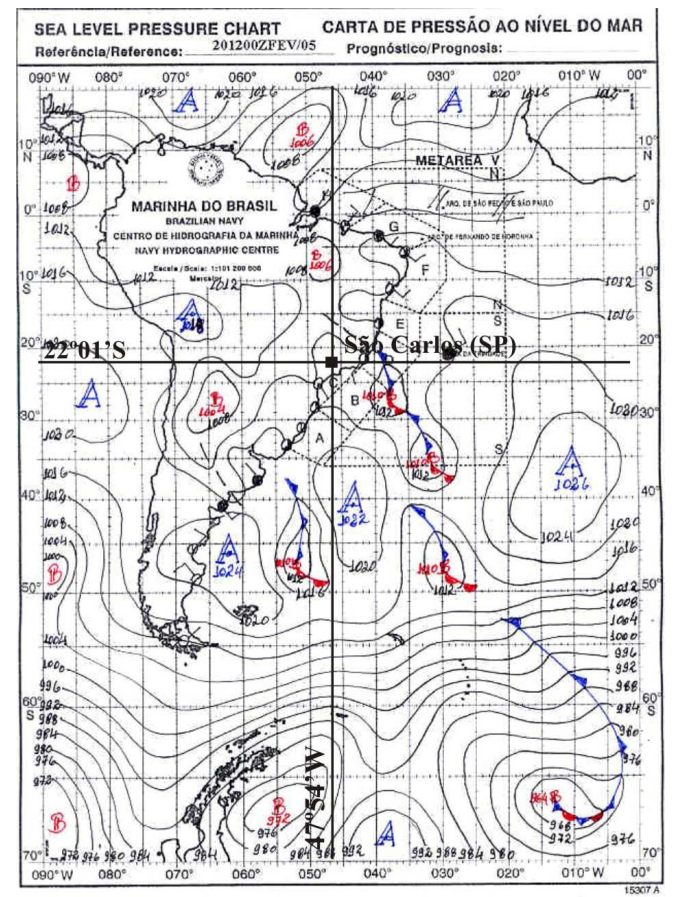

(c)
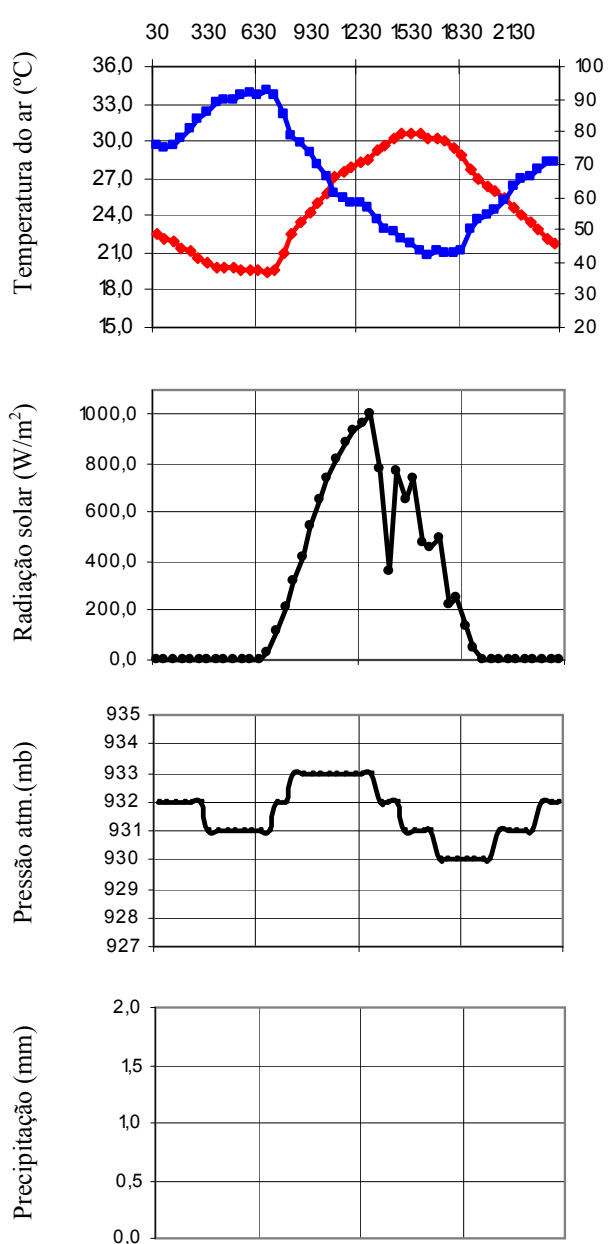

Direção do ar $\rightarrow \swarrow \searrow \searrow \swarrow \downarrow \searrow \searrow$

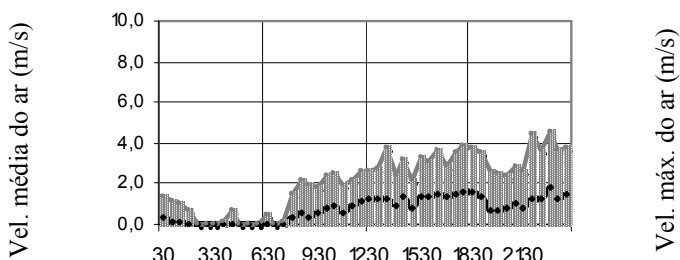

Legenda:

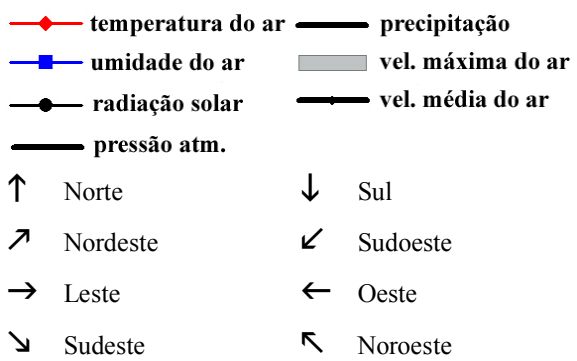

Figura 21: (a) Imagem do satélite GOES 12, canal 4 (infravermelho), e (b) carta de pressão ao nível do mar às 9:00h (horário local) do dia 20/02/2005. (c) Análise rítmica horária com registro dos elementos climáticos tomados a cada 30 minutos. 


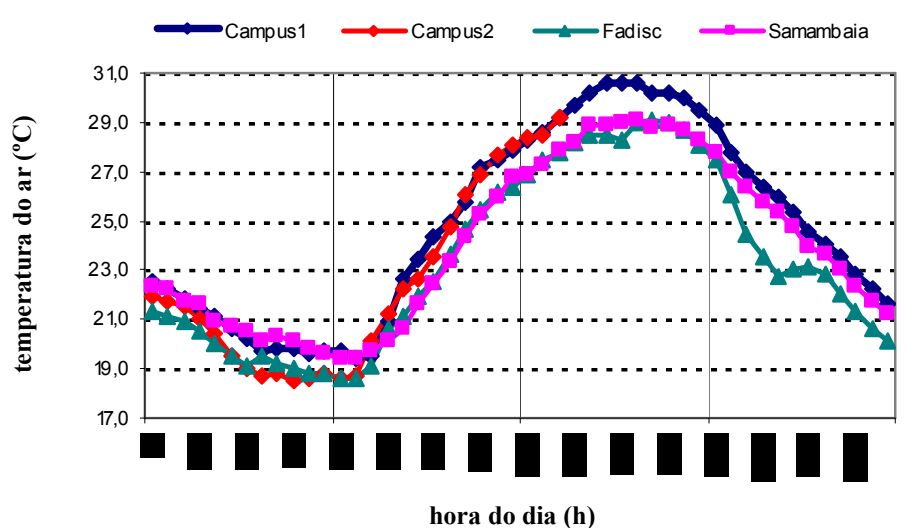

Gráfico 3: Comportamento da temperatura do ar registrada no dia 20/02/2005 nas quatro estações urbanas.

Durante a madrugada, todas as estações apresentaram redução contínua nos valores de temperatura do ar, evidenciando a perda de energia calorífica por radiação noturna, haja vista a ocorrência de aragem durante esse período do dia. $\mathrm{O}$ resfriamento mais acentuado foi observado na estação no Campus II com variação de $3,4^{\circ} \mathrm{C}$, evidenciando perda mais rápida da radiação calorífica, alcançando a mínima diária às $5: 00 \mathrm{~h}\left(18,2^{\circ} \mathrm{C}\right)$. Nas demais estações a temperatura mínima diária foi registrada às $7: 00 \mathrm{~h}$.

Após o nascer do Sol, as estações no Campus I e no Campus II se destacaram por apresentar aquecimento matinal mais acentuado. A estação no Campus I apresentou a maior temperatura diária às $15: 00 \mathrm{~h}\left(30,6^{\circ} \mathrm{C}\right)$. Nas estações na Fadisc e no Samambaia, o aquecimento foi mais lento, com a temperatura máxima diária registrada após às 16:00h e picos inferiores ao registrado na estação no Campus I. A estação no Campus II não pode ser considerada na análise desse dia devido a uma interrupção dos registros climáticos a partir das 13:30h, retornando o funcionamento apenas no dia seguinte.

Após o pôr-do-sol, houve tendência de resfriamento em todas as estações. Observou-se, entretanto, acentuado resfriamento da estação na Fadisc após às 19:00h - comportamento observado também nos demais dias analisados. Nas demais estações, o resfriamento foi gradativo, com tendência a homogeneidade na temperatura do ar nas outras duas estações analisadas (Campus I e Samambaia).

A estação no Campus I apresentou a maior amplitude térmica diária $\left(11,2^{\circ} \mathrm{C}\right)$, apresentando, também, a maior temperatura máxima diária $\left(30,6^{\circ} \mathrm{C}\right)$. Esse comportamento térmico era esperado na estação no Campus I, visto que está localizada numa área densamente construída. A menor amplitude térmica foi registrada na estação no Samambaia $\left(9,7^{\circ} \mathrm{C}\right)$, a qual também registrou a menor 
temperatura mínima diária $\left(19,4^{\circ} \mathrm{C}\right)$, ao nascer do Sol. A estação na Fadisc destacouse por registrar as menores temperaturas durante todo o dia, embora sua amplitude térmica diária tenha sido $10,5^{\circ} \mathrm{C}$.

O Gráfico 4 apresenta as diferenças de temperatura do ar observada entre as estações automáticas, duas a duas, ao longo o dia 20/02/2005. A partir da análise do Gráfico 4, notou-se que as diferenças de temperatura do ar entre as estações analisadas foram pequenas, fato que denotou homogeneidade no campo térmico urbano. A maior diferença do ar no período diurno foi de $2,3^{\circ} \mathrm{C}$, registrado entre as estações no Campus I e na Fadisc, às 15:30h. No mesmo horário, também se observou diferença entre as estações no Campus I e na Samambaia na ordem de $1,7^{\circ} \mathrm{C}$. Essas diferenças devem-se ao maior aquecimento no Campus I em relação às outras duas estações nesse horário do dia.

a)

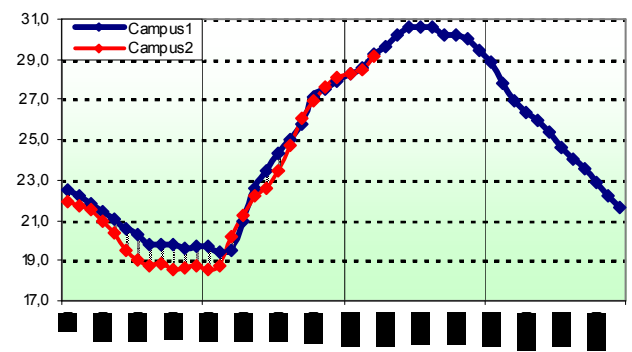

c)

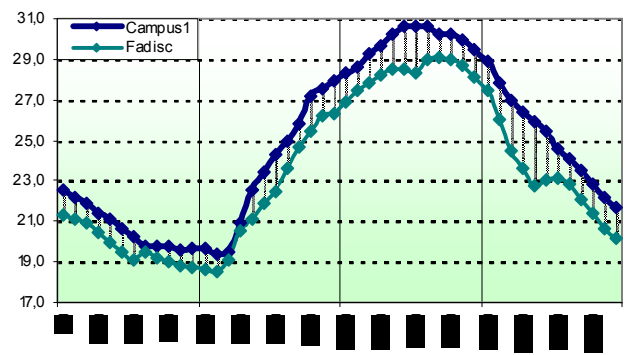

e)

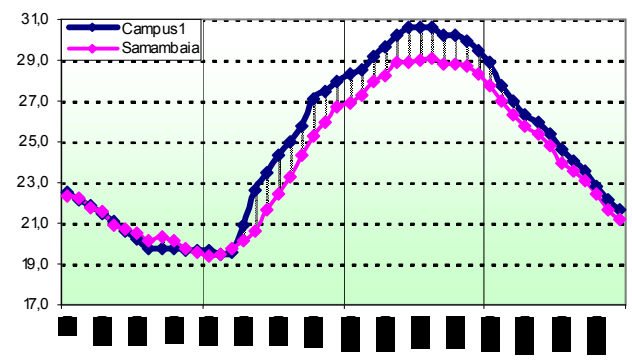

b)

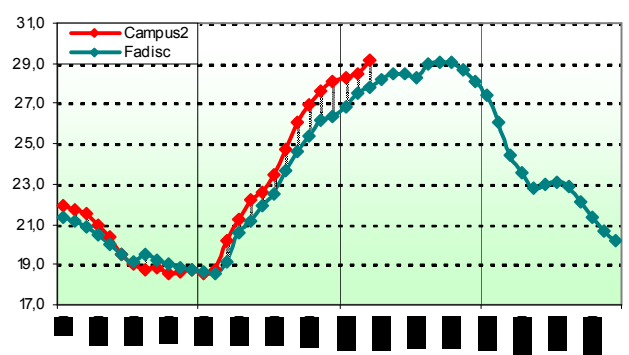

d)

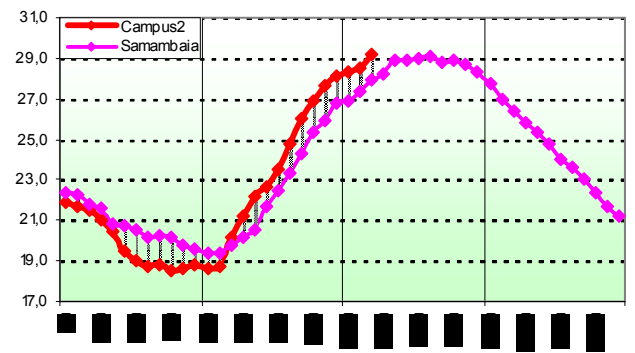

f)

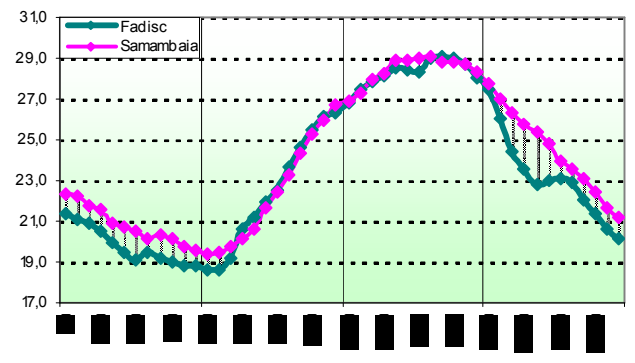

Gráfico 4: Diferenças no comportamento da temperatura do ar registrada no dia 20/02/2005 nas quatro estações urbanas, analisadas duas a duas.

Com relação às diferenças do ar entre as estações no período noturno, observou-se acentuada diferença entre as estações no Campus I e na Fadisc, na ordem de $3,2^{\circ} \mathrm{C}$, e entre as estações da Fadisc e do Samambaia, na ordem de $2,6^{\circ} \mathrm{C}$., ambas registradas às 20:30h. Esse fato não indicou, necessariamente, à formação de 
ilha de calor urbano nas regiões do Campus I e do Samambaia, visto que as diferenças do ar observadas no período noturno relacionaram-se ao rápido resfriamento registrado na estação na Fadisc após o pôr-do-Sol em relação às outras duas estações.

Observou-se, ainda, que a pequena diferença de temperatura do ar entre as estações no Campus I e no Samambaia no período noturno, na ordem de $0,6^{\circ} \mathrm{C}$, traduziu a semelhança no comportamento térmico registrado nessas estações. Salienta-se, entretanto, que a estação no Campus II não foi analisada no período noturno devido à uma interrupção dos registros climáticos a partir das 13:30h.

O comportamento da temperatura do ar nas estações urbanas também foi projetado em uma matriz de análise, a qual permitiu avaliar a intensidade da diferença térmica entre as estações automáticas, correlacionadas duas a duas. A leitura horizontal dos gráficos da matriz de análise permitiu acompanhar o comportamento diário de cada estação em relação às demais, indicando maior ou menor aquecimento do ar de acordo com a respectiva projeção acima ou abaixo do eixo das abcissas. A leitura vertical dos gráficos da matriz permitiu a análise das estações automáticas tomadas a partir de uma estação de referência, indicada acima de cada respectiva coluna.

Dessa forma, a leitura horizontal da matriz de análise (Gráfico 5) permitiu observar, de forma clara, que a região do Campus I manteve-se mais aquecida em relação às temperaturas do ar registradas nas demais estações ao longo do dia. $\mathrm{A}$ diferença com relação à estação no Campus II foi acentuada durante a madrugada, porém com pouca intensidade, chegando à diferença máxima de $1,2^{\circ} \mathrm{C}$ entre as duas estações. Essa diferença térmica justificou-se pelo resfriamento acentuado observado no Campus II nesse período do dia, observado, também, nas demais madrugadas de céu claro do episódio climático analisado.

Ainda com relação à leitura horizontal dos gráficos relacionados ao Campus I, observou-se o comportamento análogo entre a estação no Campus I e no Samambaia durante a madrugada, traduzido pela pequena diferença térmica indicada entre as duas estações nesse período do dia. Entretanto, as diferenças de temperatura do ar observadas entre elas acentuaram bruscamente ainda no período da manhã, alcançando pico de $2^{\circ} \mathrm{C}$, às $8: 30 \mathrm{~h}$, justificado pelo aquecimento acentuado na região do Campus I, devido à sua característica de maior densidade construída em relação ao condomínio Samambaia. Durante o período vespertino, observou-se tendência de diferença térmica entre as duas estações manter-se em valor próximo a $1,5^{\circ} \mathrm{C}$ até $\mathrm{o}$ pôr-do-sol, quando decresceu gradativamente, tendendo a se anular ao nascer do Sol do dia seguinte. 


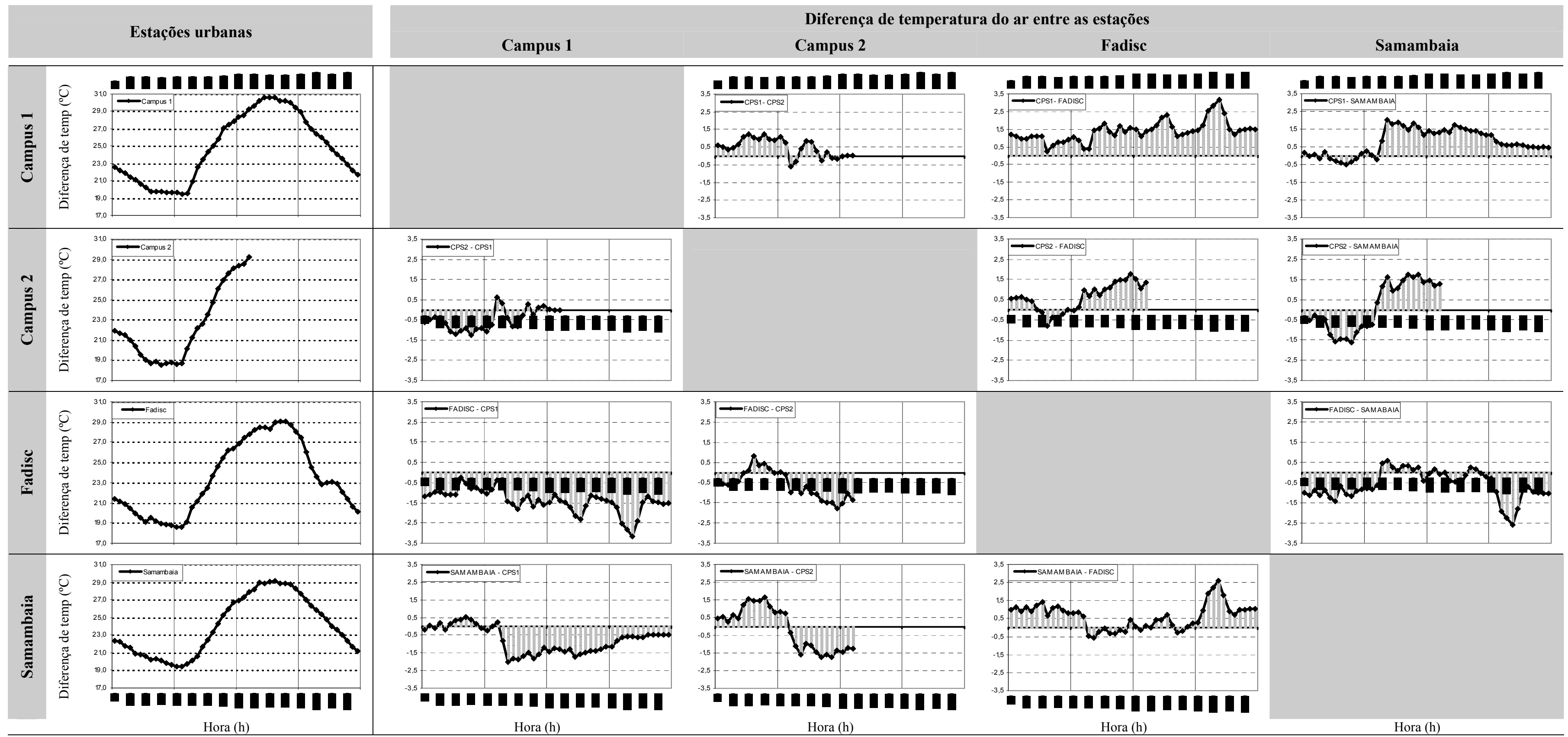

Gráfico 5: Matriz de análise do comportamento térmico das quatro estações automáticas no dia 20/02/2005. A leitura horizontal dos gráficos permite acompanhar o comportamento diário de cada estação em relação às demais, indicando maior ou menor aquecimento do ar de acordo com a projeção acima ou abaixo do eixo das coordenadas, respectivamente, enquanto a leitura vertical dos gráficos permite a análise das estações automáticas tomadas a 
Com relação à leitura horizontal da matriz de análise para o Campus II, esta não pode ser conclusiva para esse dia, devido à interrupção no registro dos dados climáticos a partir da 13:30h. Entretanto, os dados disponíveis mostraram tendência de maior aquecimento na região do Campus II em relação às estações localizadas na Fadisc e no Samambaia, evidenciado após o nascer do Sol, com diferenças térmicas superiores a $1,5^{\circ} \mathrm{C}$, já no período matutino, ao tempo que demonstrou o comportamento análogo entre essa estação e a estação no Campus I, traduzido, sobretudo, pela diferença nula entre as duas estações à partir das 12:30h.

A leitura horizontal dos gráficos da matriz de análise permitiu observar, ainda, que a estação da Fadisc apresentou temperaturas do ar inferiores às demais estações ao longo de todo o dia, com diferenças acentuadas após o pôr-do-sol. Destacou-se, entretanto, a acentuada diferença térmica entre as estações na Fadisc e no Campus I ao longo de todo o dia, a qual apresentou maior pico às $20: 30 \mathrm{~h}$, na ordem de $3,2^{\circ} \mathrm{C}$. Esse pico também foi observado no mesmo horário entre as estações na Fadisc e no Samambaia, com intensidade semelhante, na ordem de $2,6^{\circ} \mathrm{C}$. Esse fato justificou-se pela acentuada perda de radiação calorífica observada na região da Fadisc após o pôrdo-sol - tendência observada, também, nos demais dias do episódio climático analisado.

\section{- Dia 21 de fevereiro de 2005}

No dia 21/02/2005, as características higrotérmicas seguiram a tendência do dia anterior, com atmosfera estável, indicando continuidade da fase de tropicalização iniciada no dia precedente. Nesse dia, a amplitude térmica diária registrada foi de $12,3^{\circ} \mathrm{C}$, com máxima de $30,2^{\circ} \mathrm{C}$, às $16: 30 \mathrm{~h}$, e mínima de $17,9^{\circ} \mathrm{C}$, às $6: 30 \mathrm{~h}$. Os índices de umidade relativa do ar permaneceram em decréscimo, com registros abaixo dos $50 \%$ a partir das $11: 00 \mathrm{~h}$, com mínima de $32 \%$ às $13: 30 \mathrm{~h}$.

O gráfico dos valores horários da radiação solar global (ver Figura 23c) evidenciou a continuidade da curva parabólica, indicando céu claro. A radiação solar global atingiu pico de $981 \mathrm{~W} / \mathrm{m}^{2}$, às $13: 00 \mathrm{~h}$, com média diária de $308,9 \mathrm{~W} / \mathrm{m}^{2}$, ao longo de 13 horas de insolação. Apesar da permanência de céu claro durante a maior parte do dia, os valores das máximas da temperatura do ar permaneceram semelhantes ao registrado no dia anterior, ao tempo que os valores das mínima apresentou pequena redução, com mencionado anteriormente. A pressão atmosférica variou $4 \mathrm{mb}$, com pico de $933 \mathrm{mb}$, entre $9: 30 \mathrm{~h}$ e $11: 30 \mathrm{~h}$, e mínima de $929 \mathrm{mb}$, a partir das $16: 00 \mathrm{~h}$ até às $20: 30 h$. 
Os ventos predominantes permaneceram no quadrante SE, o que sugeriu a permanência da massa Polar Atlântica sobre a região, mas já em fase avançada de tropicalização. Durante o período matutino, predominou brisa leve, com velocidades do ar inferiores a $2,5 \mathrm{~m} / \mathrm{s}$ e alternância na direção SE/E. No período vespertino observouse pequeno incremento na velocidade do ar, com rajadas de $4 \mathrm{~m} / \mathrm{s}$ na direção $\mathrm{SE}$, com predomínio de brisa fraca.

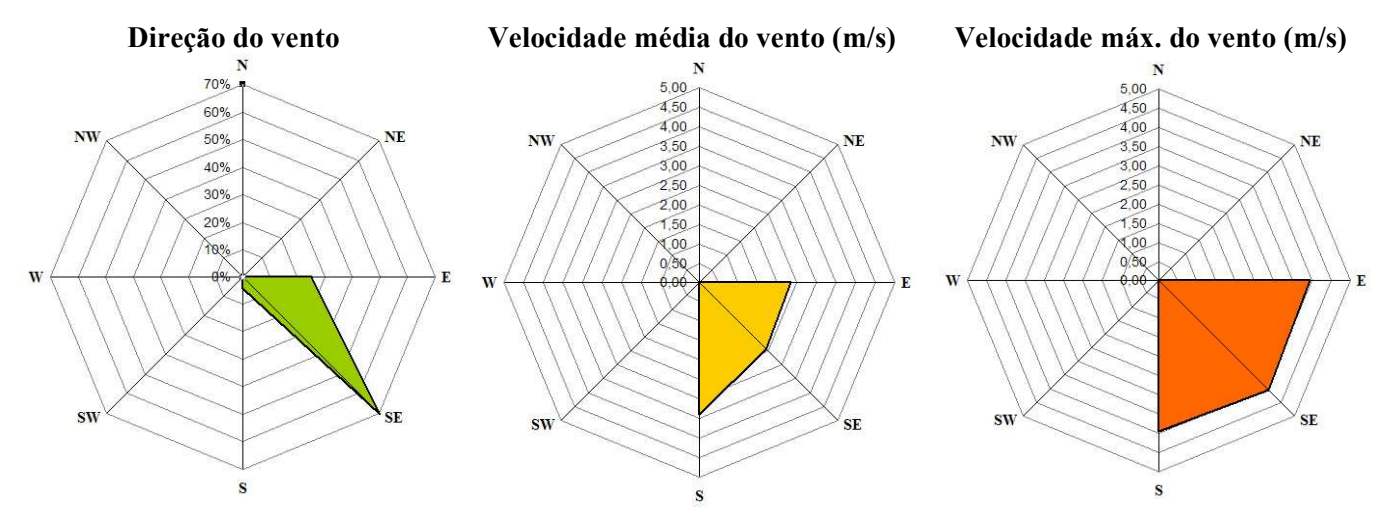

Figura 22: Rosa dos ventos com a dinâmica da circulação do ar no dia 21/02/2005, obtidos por meio de registros de direção e velocidade dos ventos tomados por média a cada 30 minutos pela estação automática localizada no Campus I.

Observou-se, assim, que o cenário atmosférico apresentou pouca alteração em relação ao dia anterior, permanecendo estável, porém seguindo a tendência de aumento da amplitude térmica diária, decréscimo no índice de umidade relativa e estabilidade nos valores da temperatura máxima do ar. A alteração mais significativa referiu-se à permanência de céu claro durante todo o dia, possivelmente resultado do decréscimo observado nos índices de umidade relativa do ar, permitindo maior aquecimento das superfícies e conseqüente avanço no processo de tropicalização da massa de ar polar sobre a região.

A imagem do canal infravermelho do satélite GOES 12 mostrou o sistema frontal em fase de dissipação sobre o estado da Bahia, ao tempo que pode-se observar a expansão do centro de baixa pressão sobre a região de São Carlos por meio da carta de pressão ao nível do mar (Figura 23).

Nesse dia, o comportamento da temperatura do ar registrada nas quatro estações urbanas foi semelhante ao comportamento observado no dia anterior, apresentando pequenas diferenças nos valores absolutos. O Gráfico 6 apresenta o comportamento da temperatura do ar em todas as estações analisadas. 
(a)

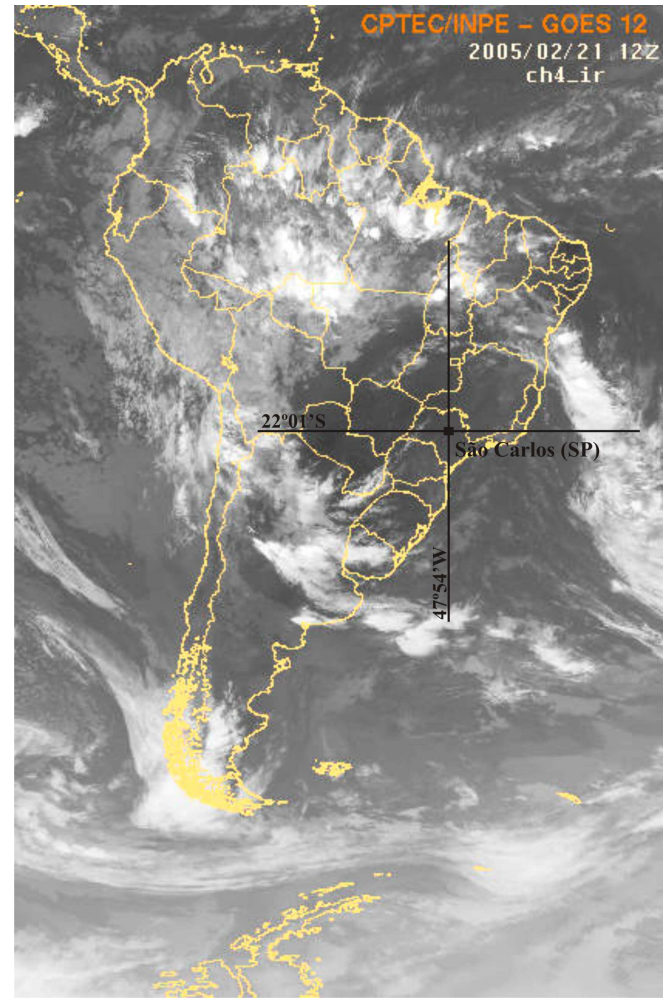

(b)

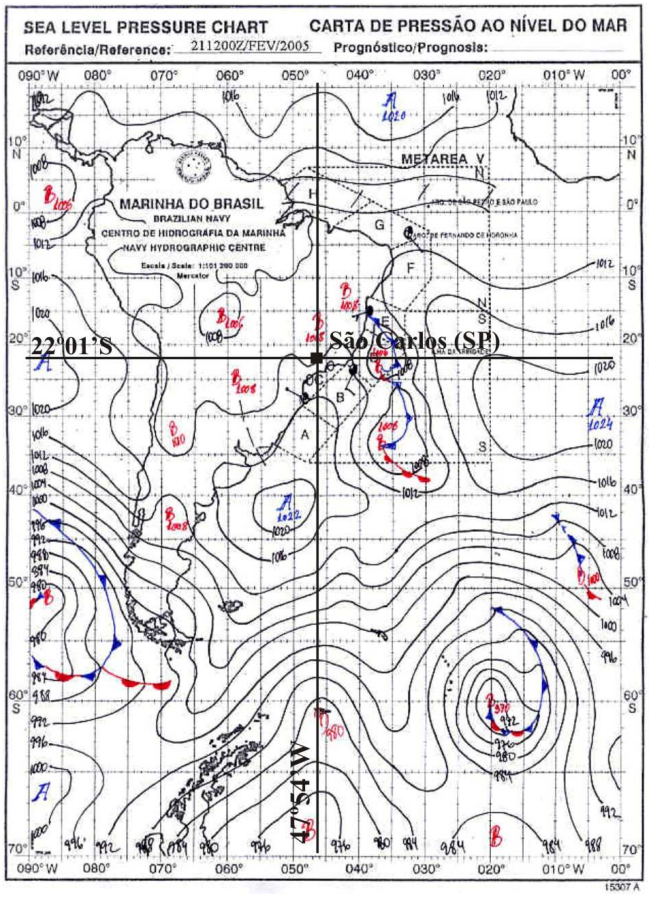

(c)

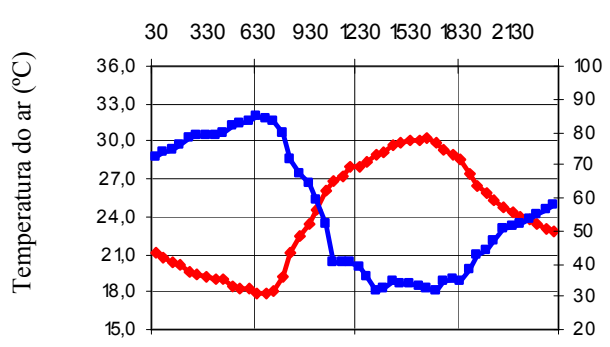

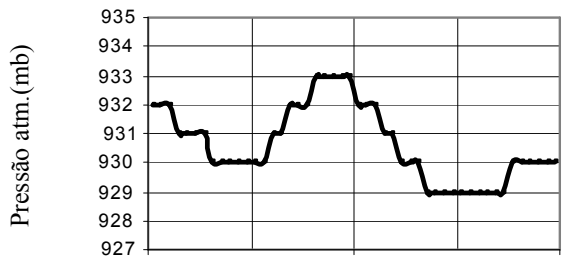

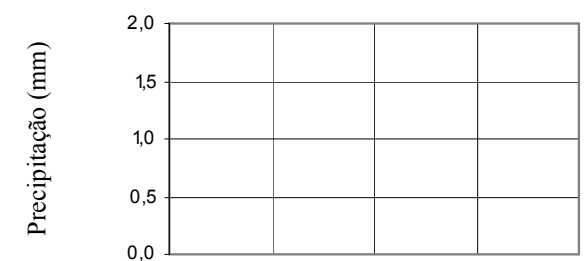

Direção do ar $\searrow \rightarrow \searrow \searrow \searrow \searrow \searrow \searrow$

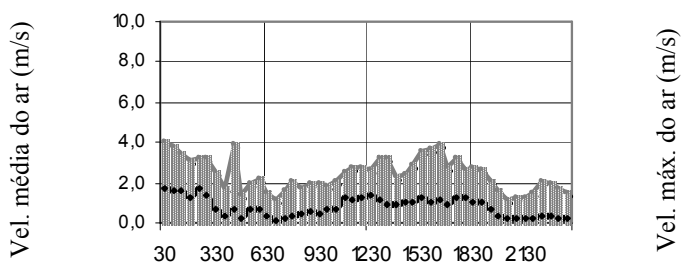

Legenda:

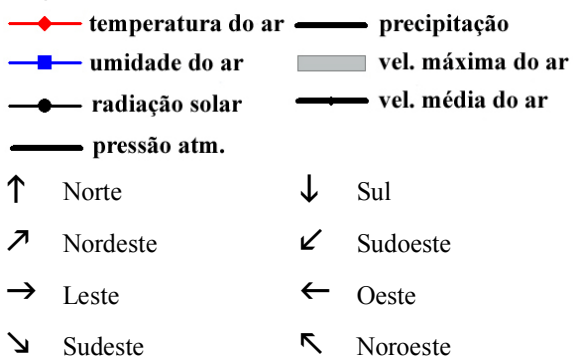

Figura 23: (a) Imagem do satélite GOES-12, canal 4 (infravermelho), e (b) carta de pressão ao nível do mar às 9:00h (horário local) do dia 21/02/2005. (c) Análise rítmica horária com registro dos elementos climáticos tomados a cada 30 minutos. 


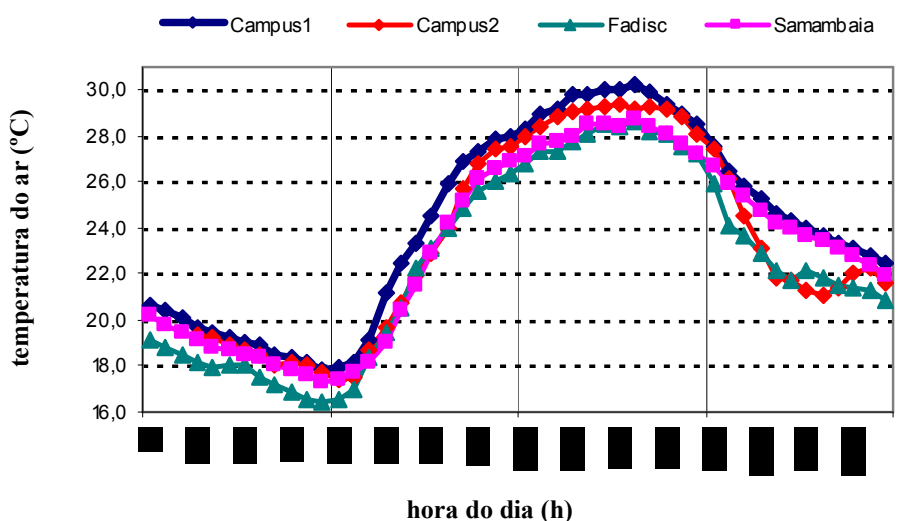

Gráfico 6: Comportamento da temperatura do ar registrada no dia 21/02/2005 nas quatro estações urbanas.

Observou-se que, durante a madrugada, o comportamento das estações foi bastante homogêneo, com exceção da estação na Fadisc que se destacou por apresentar as menores temperaturas nesses horários, com mínima de $16,5^{\circ} \mathrm{C}$ no nascer do Sol. Durante o aquecimento matinal, as estações continuaram apresentando homogeneidade, com exceção da estação no Campus I que registrou aquecimento acentuado, destacando-se por apresentar as maiores temperaturas diurnas, com pico de $30,2^{\circ} \mathrm{C}$, às $16: 00 \mathrm{~h}$ - horário no qual também foram registradas a máxima nas demais estações, porém com menores valores de temperatura do ar.

No período vespertino, destacaram-se as estações na Fadisc e no Samambaia por apresentar menor aquecimento, com pico de $28,6^{\circ} \mathrm{C}$ e $28,7^{\circ} \mathrm{C}$, respectivamente. Após o pôr-do-sol, observou-se tendência de resfriamento em todas as estações, com destaque ao resfriamento acentuado ocorrido nas estações na Fadisc e no Campus II.

A amplitude térmica diária foi semelhante em todas as estações, próxima de $12^{\circ} \mathrm{C}$, com exceção da estação no Samambaia que apresentou amplitude térmica diária um pouco menor $\left(11,4^{\circ} \mathrm{C}\right)$, devido ao menor resfriamento noturno e ao menor aquecimento diurno observado durante o dia.

O Gráfico 7 apresenta as diferenças de temperatura do ar observada entre as estações automáticas, duas a duas, ao longo o dia 21/02/2005. A partir da análise dos gráficos, notou-se que as diferenças de temperatura do ar entre as estações analisadas foram semelhantes às observadas no dia precedente, fato que sugeriu a permanência da homogeneidade no campo térmico urbano na fase de tropicalização. A maior diferença do ar no período diurno foi de $2,1^{\circ} \mathrm{C}$, registrado entre as estações no Campus I e na Fadisc, às 14:00h. No mesmo horário, também se observou diferença entre as estações no Campus I e na Samambaia na ordem de $1,8^{\circ} \mathrm{C}$. Essas diferenças 
deveram-se ao maior aquecimento no Campus I em relação às demais estações nesse horário do dia - fato também observado no dia precedente.

a)

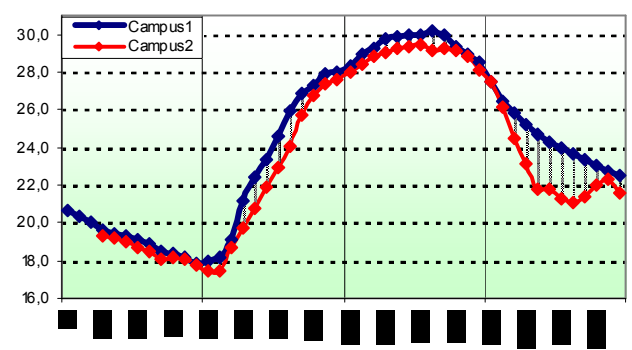

c)

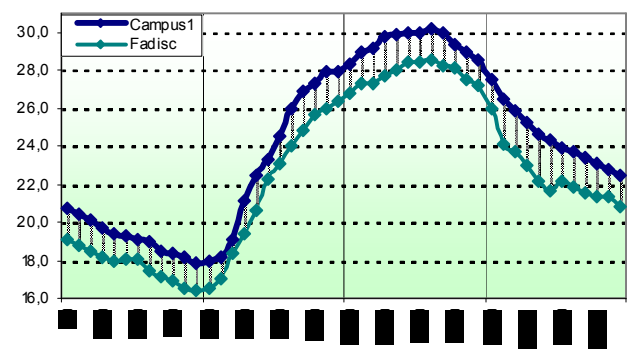

e)

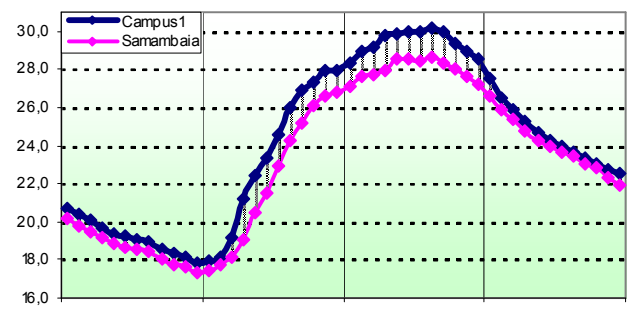

-IIIIIIIIIII b)

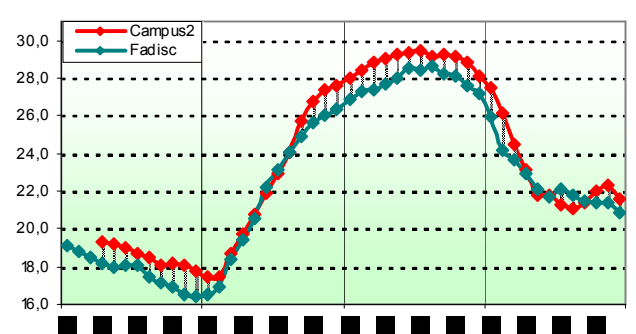

d)

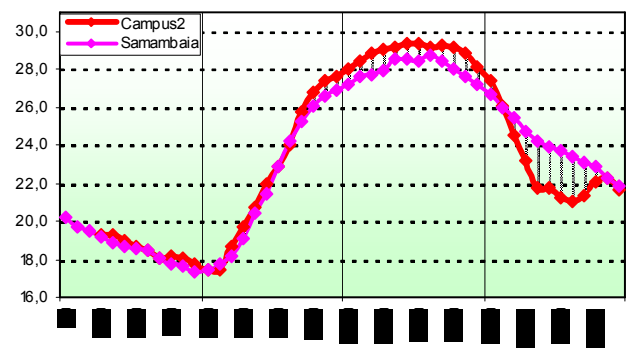

f)

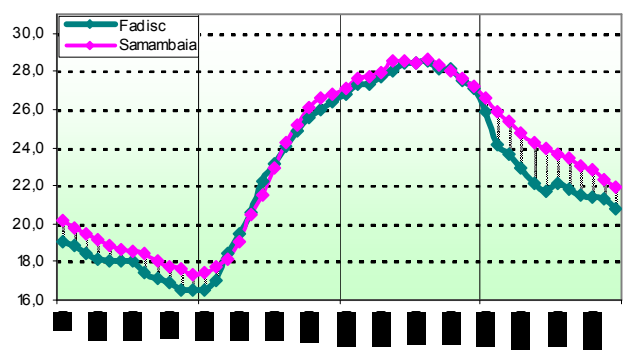

Gráfico 7: Diferenças no comportamento da temperatura do ar registrada no dia 21/02/2005 nas quatro estações urbanas, analisadas duas a duas.

Com relação às diferenças do ar entre as estações no período noturno, observou-se acentuada diferença entre as estações no Campus I e na Fadisc, na ordem de $2,6^{\circ} \mathrm{C}$, e entre as estações na Fadisc e no Samambaia, na ordem de $2,3^{\circ} \mathrm{C}$, ambas registradas às $21: 00 \mathrm{~h}$. Também foram observadas diferenças acentuadas entre as estações no Campus I e no Campus II, na ordem de $2,9^{\circ} \mathrm{C}$, e entre as estações no Campus II e no Samambaia, na ordem de $2,5^{\circ} \mathrm{C}$. Esse fato evidenciou que, após o pôrdo-sol, o comportamento da estação no Campus I foi análogo ao comportamento observado na estação no Samambaia, assim como foi análogo o comportamento térmico entre as estações no Campus II e na Fadisc - neste caso, com acentuado resfriamento após às 19:00h. A observação desse fato sugeriu a formação de ilha de calor urbano nas regiões do Campus I e do Samambaia, pouco tempo após o pôr-dosol.

A leitura horizontal da matriz de análise (Gráfico 8) permitiu observar que a temperatura do ar na região do Campus I manteve-se mais aquecida em relação às 
demais estações no decorrer do dia. A diferença com relação às estações no Campus II e na Fadisc foi acentuada após o pôr-do-sol, como observado anteriormente. Entretanto, a maior diferença com relação à estação no Samambaia ocorreu no início da manhã, na ordem de $2,1^{\circ} \mathrm{C}$, devido ao maior aquecimento da estação no Campus I fato também observado com relação às estações no Campus II e na Fadisc. A diferença positiva da estação no Campus I em relação às demais estações indicou ser esta uma área propícia à formação de ilha de calor urbano, possivelmente devido à maior densidade de construção.

Com relação ao desempenho térmico no Campus II, a leitura horizontal dos gráficos da matriz de análise permitiu observar que foi bastante variável ao longo do dia em relação às demais. Durante a madrugada, o comportamento térmico nessa estação foi análogo ao comportamento observado nas estações no Campus I e no Samambaia. Contudo, no período noturno, observou-se intenso resfriamento, assemelhando-se ao comportamento térmico observado na estação na Fadisc.

Quanto à estação na Fadisc, observou-se que essa permaneceu menos aquecida durante todo o dia em relação às demais estações, apresentando-se um pouco mais aquecida que as estações no Campus II e na Samambaia durante um curto período de tempo no início da manhã e um aquecimento mais significativo com relação à estação no Campus II, na ordem de $2,0^{\circ} \mathrm{C}$, no início da noite, devido ao intenso resfriamento observado no Campus II.

Por fim, observou-se, ainda, que a estação no Samambaia apresentou-se menos aquecida em relação à estação do Campus I ao longo de todo o dia e pequenas diferenças térmicas com relação às outras duas estações. Entretanto, após o pôr-doSol, a estação do Samambaia apresentou temperatura do ar mais aquecida com relação às estações do Campus II e da Fadisc, sugerindo processo mais lento de perda radiação calorífica absorvida ao longo do dia. 


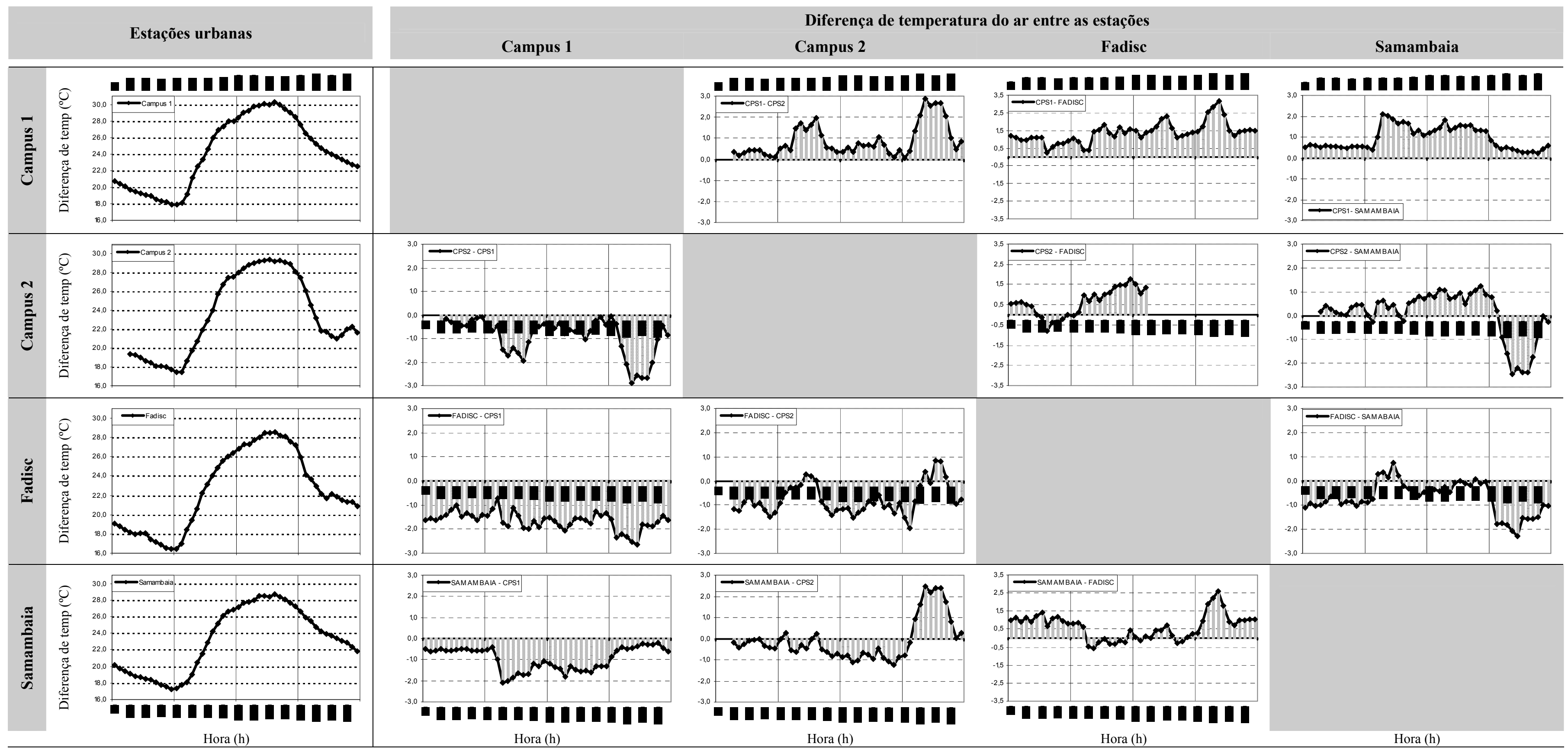

Gráfico 8: Matriz de análise do comportamento térmico das quatro estações automáticas no dia 21/02/2005. A leitura horizontal dos gráficos permite acompanhar o comportamento diário de cada estação em relação às demais, indicando maior ou menor aquecimento do ar de acordo com a projeção acima ou abaixo do eixo das coordenadas, respectivamente, enquanto a leitura vertical dos gráficos permite a análise das estações automáticas tomadas a partir de uma estação de referência, indicada acima de cada coluna. 


\section{FASE DE DOMÍNIO DA MASSA TROPICAL ATLÂNTICA}

A fase de domínio da massa Tropical Atlântica compreendeu os dias 22 e 23 de fevereiro de 2005.

\section{- Dia 22 de fevereiro de 2005}

No dia 22/02/2005 observou-se a tendência de elevação da amplitude térmica diária. Nesse dia, a amplitude foi da ordem de $16,3^{\circ} \mathrm{C}$. A temperatura máxima do ar foi registrada às $16: 00 \mathrm{~h}-32,3^{\circ} \mathrm{C}$ - e a temperatura mínima pouco após o nascer do Sol, às 7:00h $-16,0^{\circ} \mathrm{C}$. Apesar do maior aquecimento do ar, os índices de umidade relativa do ar sofreram pequena alteração com relação aos índices registrados nos dias precedentes, apresentando mínima de $33 \%$, às $16: 00 \mathrm{~h}$, e máxima de $86 \%$, às $7: 00 \mathrm{~h}$, coincidindo com os horários de maior e menor temperatura do ar, respectivamente.

O gráfico dos valores horários de radiação solar global evidenciou a continuidade da curva parabólica, indicando permanência de céu claro. Os valores registrados atingiram pico de $960 \mathrm{~W} / \mathrm{m}^{2}$, às $13: 30 \mathrm{~h}$, com média diária de $302,8 \mathrm{~W} / \mathrm{m}^{2}$, ao longo de 13 horas de insolação. A elevada insolação aliada a permanência de céu claro durante todo o dia resultou em maior ação da radiação solar direta sobre as superfícies, favorecendo ao maior aquecimento superficial e, conseqüentemente, ao maior aquecimento do ar em relação ao dia anterior. A pressão atmosférica variou $3 \mathrm{mb}$, com pico de $931 \mathrm{mb}$, a partir das 8:00h permanecendo estável até às $13: 30 \mathrm{~h}$. A mínima de $928 \mathrm{mb}$ foi registrada das 19:00h às 19:30h.

Com relação aos ventos dominantes, observou-se significativa alteração em sua direção, indicando que outra massa de ar passou a atuar sobre a região. No dia $22 / 02 / 2005$, os ventos dominantes foram alternadamente dos quadrantes $\mathrm{N}$ e $\mathrm{W}$. Durante o período matutino, houve predominância dos ventos do quadrante N/NE, com brisa leve e alguns períodos de aragem. Nos períodos vespertino, houve predominância dos ventos do quadrante NW/W, com brisa leve e rajadas de brisa fraca com velocidade inferior a $4,5 \mathrm{~m} / \mathrm{s}$. No período noturno houve a predominância de calmaria, como evidenciado na Figura 24.

Observou-se, assim, que o cenário atmosférico compreendido pela curva parabólica contínua do gráfico da radiação solar direta indicando permanência de céu claro ao longo do dia, aliado às caracterísiticas higrotérmicas de elevada amplitude térmica diária evidenciam o domínio da massa Tropical Atlântica sobre a região de São Carlos. 


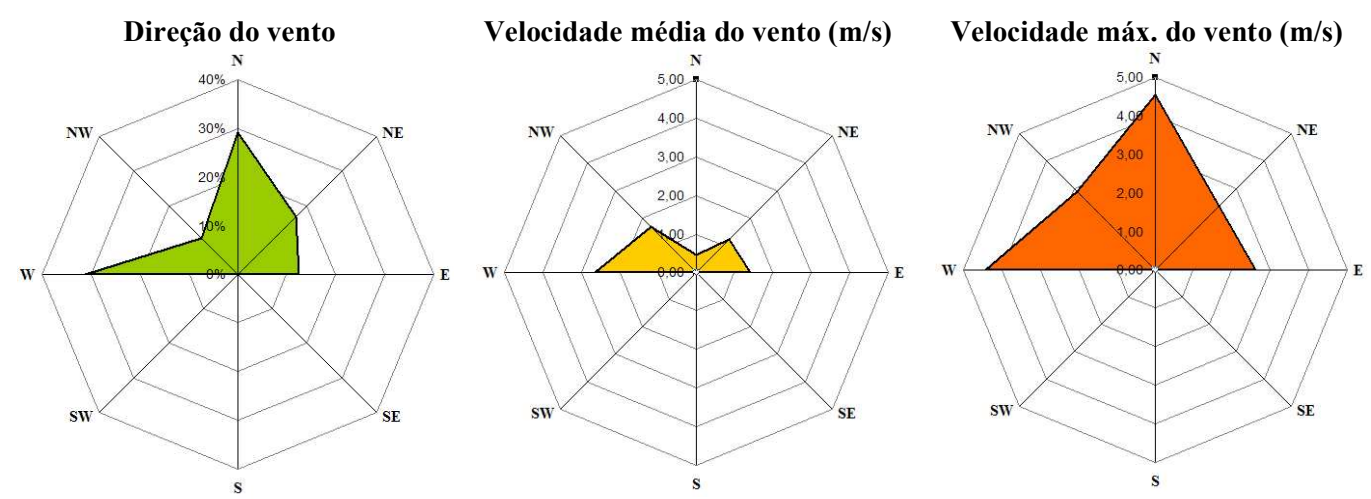

Figura 24: Rosa dos ventos com a dinâmica da circulação do ar no dia 22/02/2005, obtidos por meio de registros de direção e velocidade dos ventos tomados por média a cada 30 minutos pela estação automática localizada no Campus I.

As condições sinóticas do dia 22/02/2005 podem ser atestadas, ainda, pela imagem do canal infravermelho do satélite GOES 12 e a carta de pressão ao nível do mar (Figura 25) que mostram a permanência de um centro de baixa pressão sobre a região de São Carlos, evidenciando o domínio da massa Tropical Atlântica.

Nesse dia, o comportamento da temperatura do ar registrada nas quatro estações urbanas apresentou maiores diferenças no início da manhã e após às 20:00h, coincidindo com o período de ocorrência de aragem. O céu claro e a reduzida ventilação proporcionaram maior definição na formação de ilhas de calor urbano.

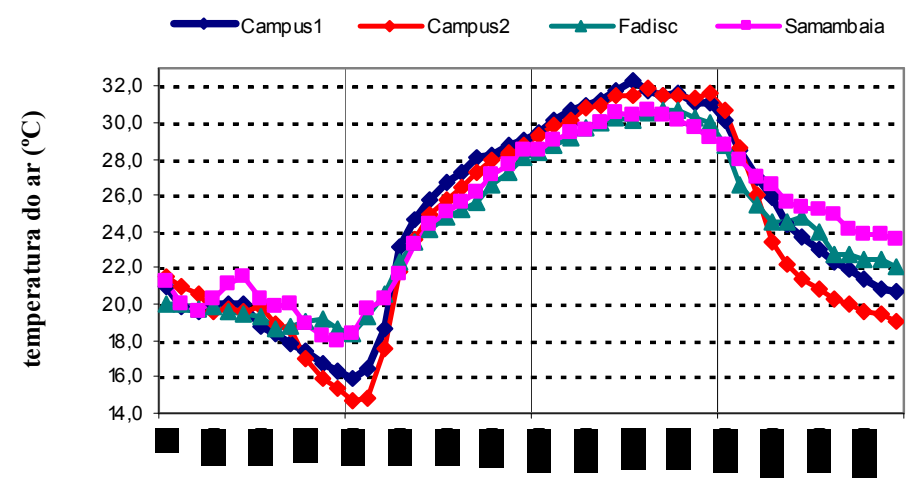

hora do dia (h)

Gráfico 9: Comportamento da temperatura do ar registrada no dia 22/02/2005 nas quatro estações urbanas.

Observou-se que durante a madrugada o comportamento das estações foi bastante homogêneo, com perda da radiação calorífica menos acentuada do que as observadas nos dois dias precedentes. Entretanto, as diferenças de temperatura do ar entre as estações foram acentuadas próximo ao nascer do Sol, quando as estações no Campus I e no Campus II apresentaram acentuado resfriamento. 
(a)

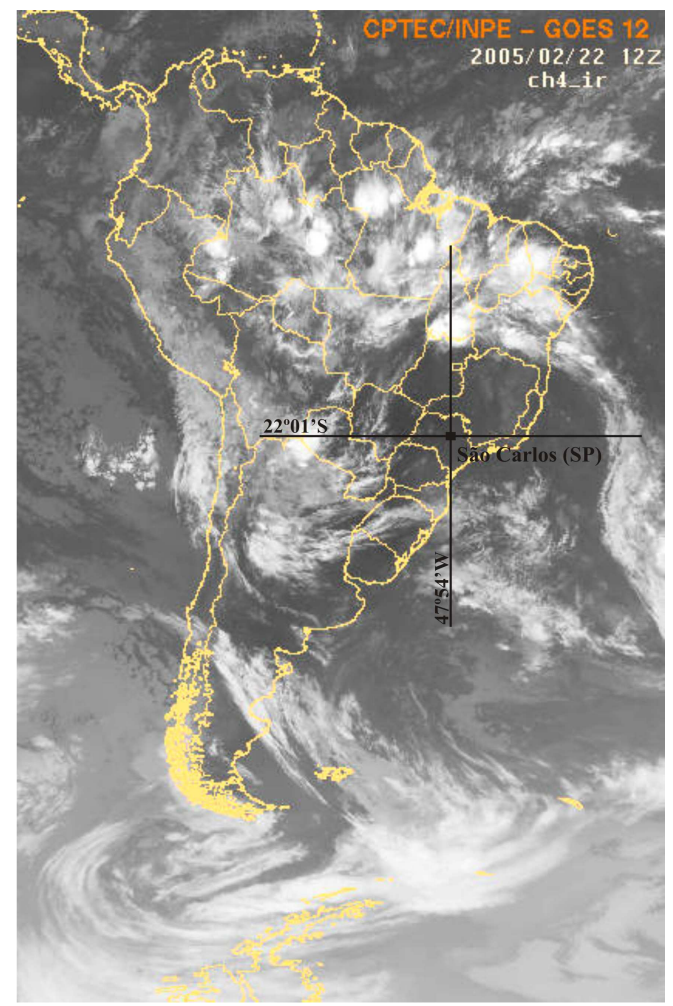

(b)

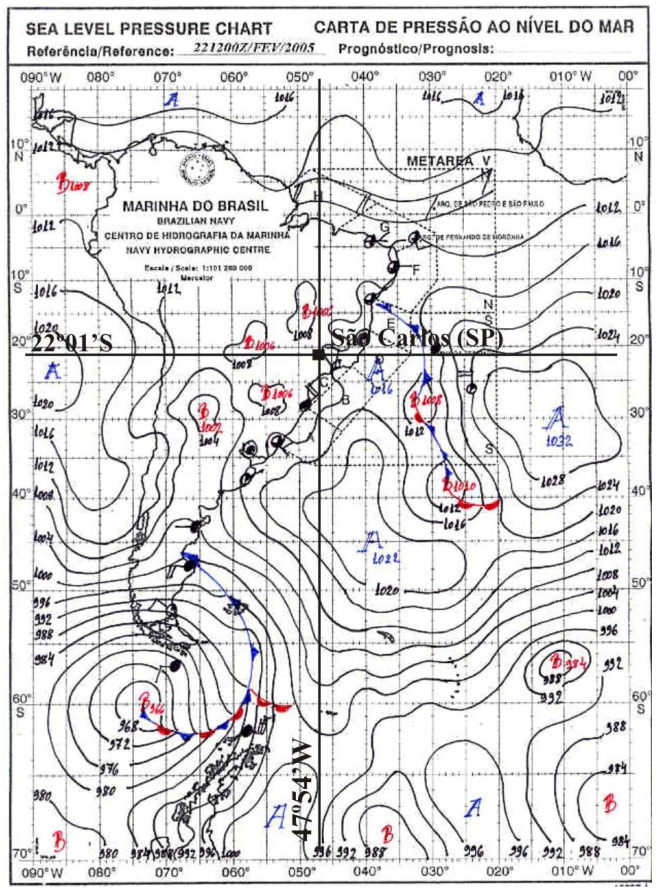

(c)
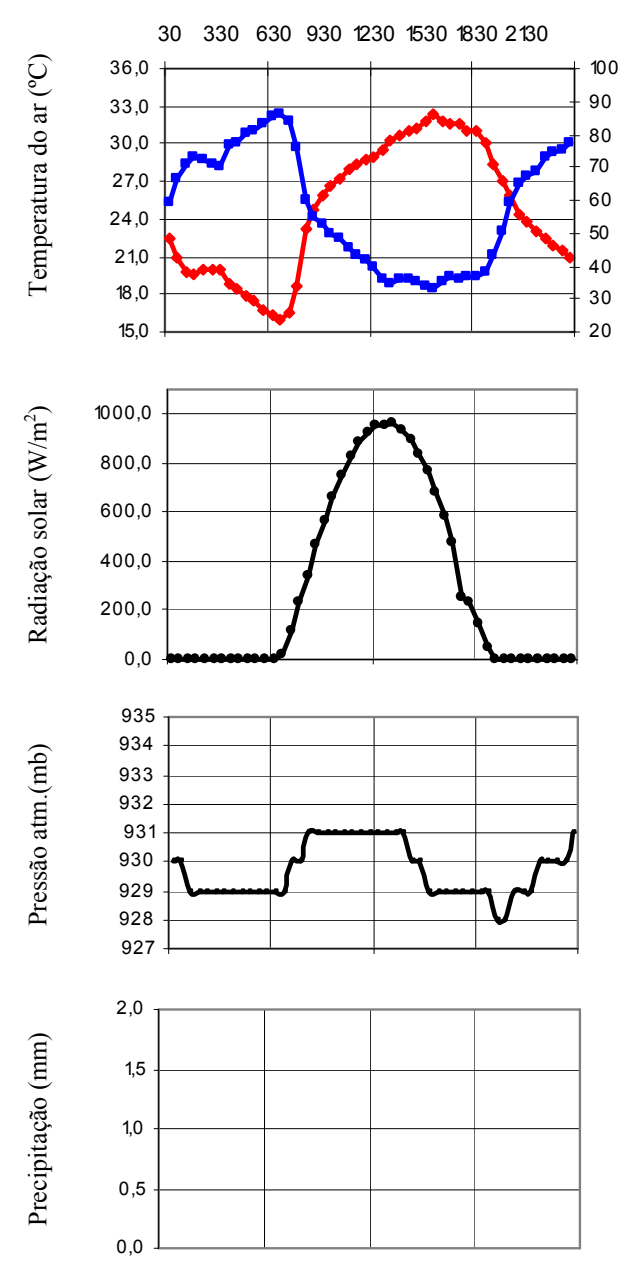

Direção do ar $\rightarrow \uparrow \uparrow \quad \nearrow \leftarrow \leftarrow \leftarrow \uparrow$

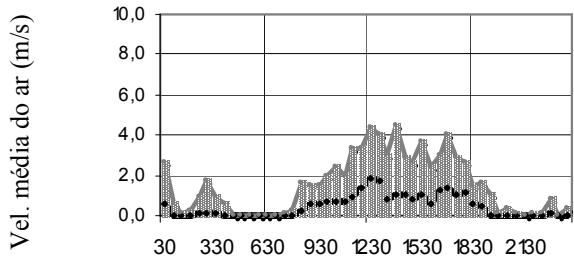

Legenda:

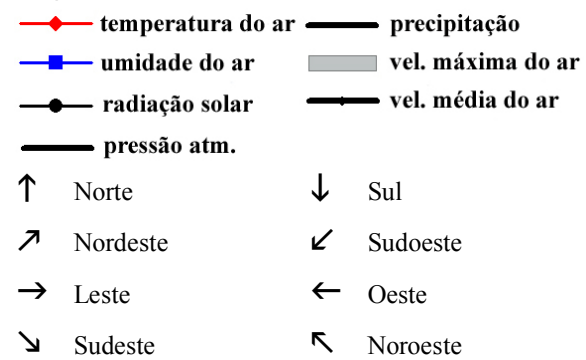

Figura 25: Imagem do satélite GOES-12, canal 4 (infravermelho), e carta de pressão ao nível do mar às 9:00h (horário local) do dia 22/02/2005 e análise rítmica horária com registro dos elementos climáticos tomados a cada 30 minutos. 
Assim, observou-se que a estação no Campus II, mais uma vez, apresentou comportamento de intenso resfriamento noturno, alcançando a temperatura mínima de $14,7^{\circ} \mathrm{C}$, às $6: 30 \mathrm{~h}$, seguida da estação no Campus I, com mínima de $16^{\circ} \mathrm{C}$. As estações na Fadisc e no Samambaia apresentaram mínima superior a $18^{\circ} \mathrm{C}$.

Durante o aquecimento matinal, as estações no Campus I e no Campus II apresentaram aquecimento acentuado, permanecendo com comportamento térmico similar durante todo período matutino e vespertino, com máximas de $32,3^{\circ} \mathrm{C}$ (Campus I) e $31,9^{\circ} \mathrm{C}$ (Campus II), às $15: 30 \mathrm{~h}$. As estações na Fadisc e no Samambaia apresentaram aquecimento mais ameno, apesar do céu claro e da forte incidência de radiação solar direta nesse dia, com pico de $30,7^{\circ} \mathrm{C}$ registrado em ambas estações, após às 16:00h. Após o pôr-do-sol, houve tendência de resfriamento em todas as estações, com destaque ao resfriamento acentuado ocorrido nas estações na Fadisc e no Campus II - fato também observado nos dias precedentes.

A amplitude térmica diária apresentou-se bastante diferente em todas as estações. A maior amplitude térmica foi registrada na estação no Campus II $\left(17,2^{\circ} \mathrm{C}\right)$, devido ao seu maior aquecimento diurno e intensa perda de radiação calorífica noturna. A menor amplitude térmica foi registrada na estação na Fadisc $\left(12,3^{\circ} \mathrm{C}\right)$, seguido da estação no Samambaia $\left(12,7^{\circ} \mathrm{C}\right)$. Ambas estações registraram as maiores temperaturas durante a madrugada, sugerindo menor perda de radiação calorífica, e menor aquecimento diurno, justificado pela maciça presença de vegetação arbórea nas duas áreas.

O Gráfico 10 apresenta as diferenças de temperatura do ar observada entre as estações automáticas, duas a duas, ao longo o dia 21/02/2005. A partir da análise dos gráficos, observou-se modificação no comportamento térmico das estações urbanas em relação aos dois dias precedentes. Notou-se acentuada diferença térmica pouco após o nascer do Sol entre as estações no Campus I e na Fadisc $\left(2,8^{\circ} \mathrm{C}\right)$ e entre as estações no Campus I e no Samambaia $\left(3,2^{\circ} \mathrm{C}\right)$. Entretanto, diferenças maiores foram registradas entre as estações no Campus II e na Fadisc $\left(4,5^{\circ} \mathrm{C}\right)$ e entre as estações no Campus II e no Samambaia $\left(4,9^{\circ} \mathrm{C}\right)$. Todas registradas no mesmo horário, às 7:00h.

As diferenças térmicas observadas nas estações urbanas pouco após o nascer do Sol deu-se, sobretudo, pela intensa perda de radiação calorífica durante a madrugada notada nas estações no Campus I e no Campus II, como comentado anteriormente. Essa maior perda de radiação calorífica observa nas duas estações em relação aos dois dias precedentes justifica-se pela dissipação da nebulosidade e predominância de céu claro, característico da fase de domínio da massa Tropical Atlântica. 
a)

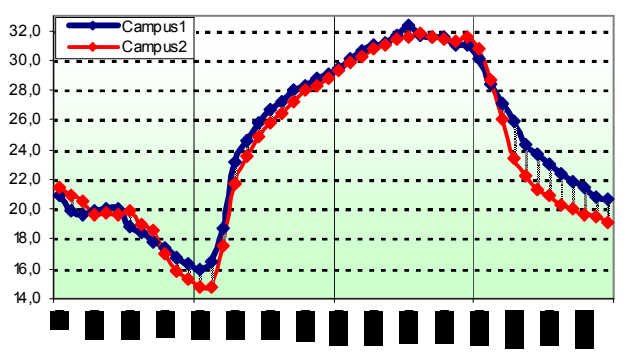

c)

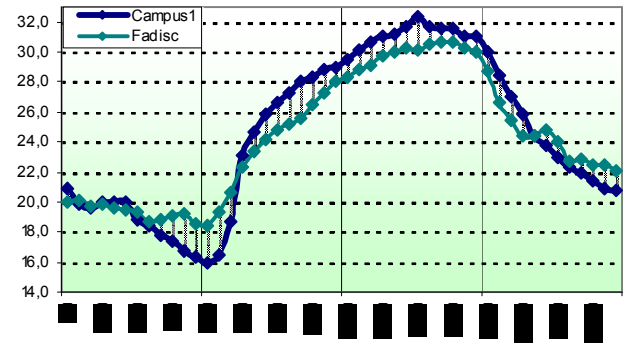

e)

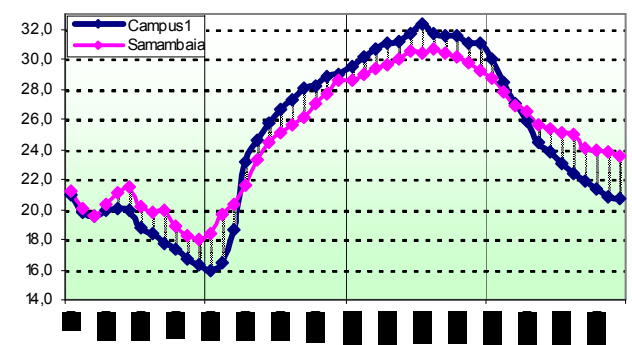

b)

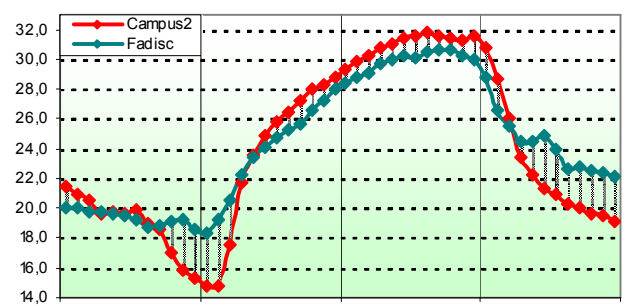

\UIIIIIIIII

d)

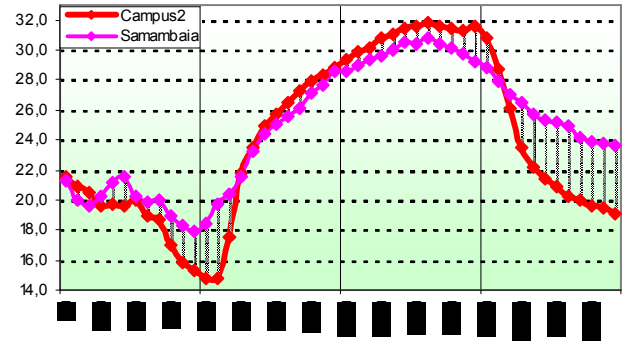

f)

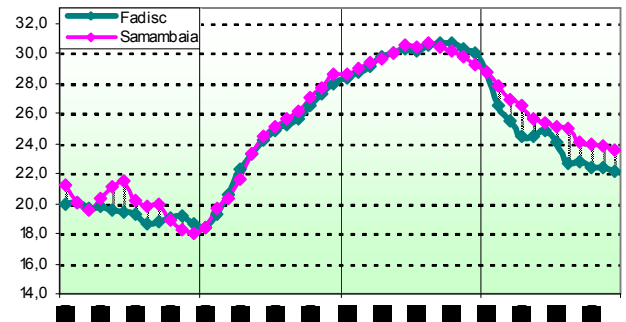

Gráfico 10: Diferenças no comportamento da temperatura do ar registrada no dia 22/02/2005 nas quatro estações urbanas, analisadas duas a duas.

Durante o período diurno, todas as estações tiveram comportamento análogo favorecido pelo intenso aquecimento das superfícies proporcionado pela permanência de céu claro. Nesses horários, a diferença térmica entre as estações foram inferiores a $1,4^{\circ} \mathrm{C}$ - máxima registrada entre as estações no Campus I e no Samambaia.

As diferenças de temperatura do ar entre as estações após o pôr-do-sol também foram observadas nesse dia, entretanto com maior intensidade do que as observadas nos dois dias precedentes. As maiores diferenças térmicas nesses horários foram registradas entre as estações no Campus II e no Samambaia, na ordem de $4,7^{\circ} \mathrm{C}$, às $22: 00 \mathrm{~h}$, e entre as estações no Campus II e na Fadisc, na ordem de $3,5^{\circ} \mathrm{C}$, às $21: 00 \mathrm{~h}$. Nesse dia, notou-se que as diferenças térmicas noturnas foram proporcionadas pelo rápido resfriamento nas estações do Campus II, diferente dos dois dias anteriores nos quais o rápido resfriamento ocorreu na estação Fadisc.

A maior diferença térmica entre as estações poucas horas após o pôr-do-sol, nesse dia, foi favorecida pela combinação de menor disponibilidade de vapor d'água na atmosfera urbana, permanência de céu claro e ocorrência de calmaria no período 
noturno. A combinação dessas condições atmosféricas propiciou maior troca de radiação calorífica com a abóbada celeste.

A leitura horizontal da matriz de análise (Gráfico 11) permitiu observar diferenças evidentes no desempenho térmico registrado em cada estação em relação aos dois dias precedentes. A leitura dos gráficos do Campus I mostrou grande variação no desempenho térmico dessa estação ao longo do dia, apresentando-se comportamento térmico menos aquecido do que as estações na Fadisc e no Samambaia durante a madrugada e após o pôr-do-sol. Contudo, durante o período diurno, a estação no Campus I voltou a apresentar maior aquecimento em relação às mesmas estações.Nos dois dias anteriores, a estação no Campus I apresentou temperatura mais elevada em todos os horários do dia.

Com relação à estação no Campus II, notou-se que essa estação apresentou comportamento análogo ao observado no Campus I, apresentando maior resfriamento especialmente ao nascer do Sol, e poucas horas após o pôr-do-sol o que indicou maior troca de radiação calorífica com a abóbada celeste, favorecido pela predominância dos ventos no quadrante $\mathrm{W}$, conforme comentado anteriormente.

Quanto ao desempenho térmico da estação na Fadisc, notou-se que essa estação apresentou-se menos aquecida com relação às demais durante o período de maior aquecimento do ar, o que sugeriu menor capacidade de aquecimento das superfícies, justificado pela presença de maciça vegetação arbórea e menor densidade de construção. Entretanto, poucas horas após o pôr-do-sol, a estação na Fadisc apresentou picos de aquecimento em relação às estações no Campus I $\left(1,9^{\circ} \mathrm{C}\right.$, às 19:00h) e no Campus II (3,5 $5^{\circ} \mathrm{C}$, às $\left.21: 00 \mathrm{~h}\right)$, fato que denotou perda de radiação calorífica mais lenta nessa área, possivelmente devido à densidade de massa arbórea presente.

Por fim, observou-se a semelhança no desempenho térmico registrado entre as estações no Campus I e no Campus II e o desempenho térmico registrado entre as estações na Fadisc e no Samambaia. Entre elas as diferenças térmicas foram pequenas, chegando a se anularem em alguns horários do dia, sobretudo no horário de maior aquecimento do ar. 


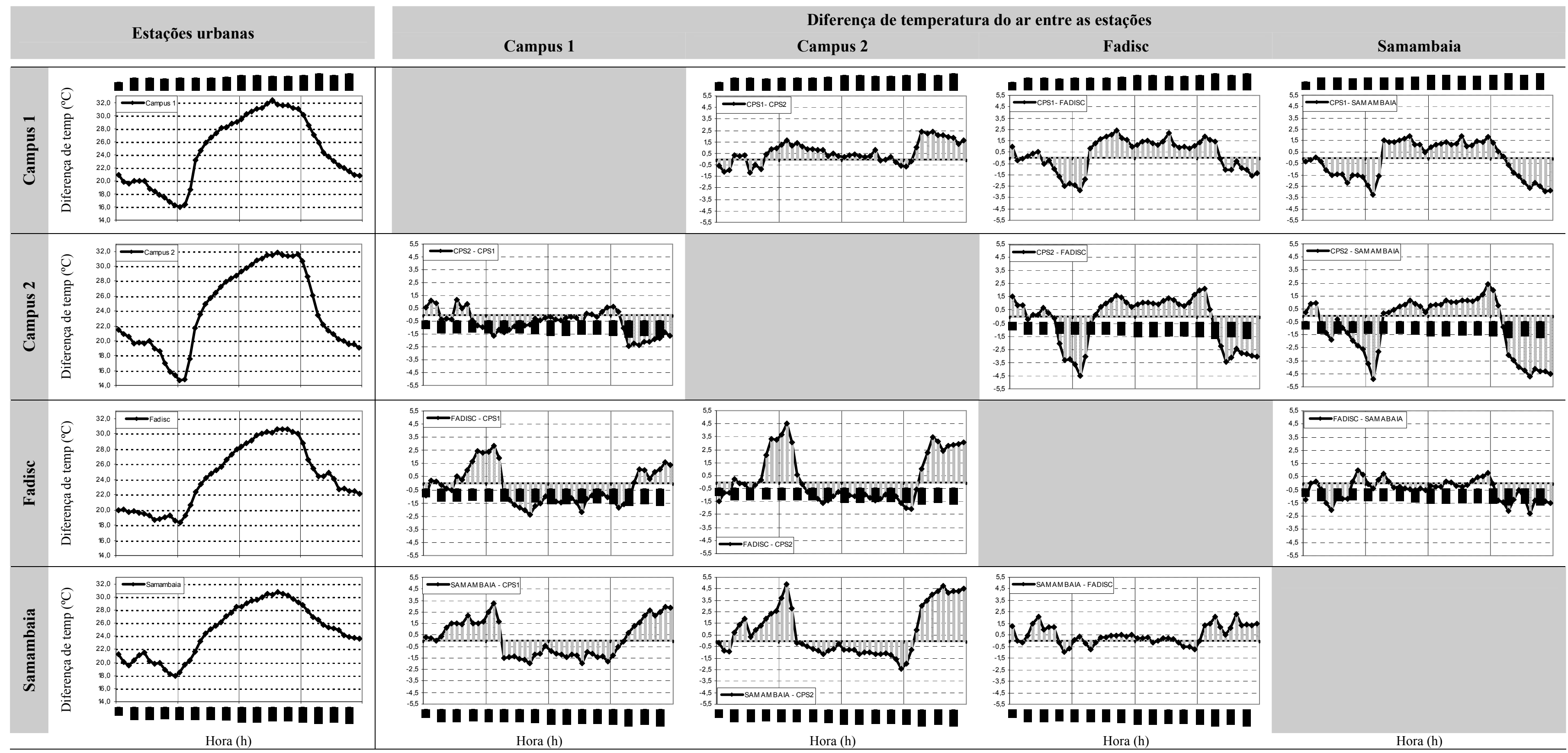

Gráfico 11: Matriz de análise do comportamento térmico das quatro estações automáticas no dia 22/02/2005. A leitura horizontal dos gráficos permite acompanhar o comportamento diário de cada estação em relação às demais, indicando maior ou menor aquecimento do ar de acordo com a projeção acima ou abaixo do eixo das coordenadas, respectivamente, enquanto a leitura vertical dos gráficos permite a análise das estações automáticas tomadas a 


\section{- Dia 23 de fevereiro de 2005}

No dia 23/02/2005 permaneceu a tendência de elevada amplitude térmica diária, da ordem de $16,1^{\circ} \mathrm{C}$. Observou-se maior aumento no valor da temperatura máxima - $33,5^{\circ} \mathrm{C}$, às $15: 30 \mathrm{~h}$ - e pequena elevação da mínima diária, no valor de $17,4^{\circ} \mathrm{C}$, às 7:00h (pouco após o nascer do Sol). Os registros de umidade relativa do ar alcançaram os menores índices de todo o verão de 2005, permanecendo abaixo dos $50 \%$ a partir das $9: 30 \mathrm{~h}$, com mínima de $24 \%$, às $16: 30 \mathrm{~h}$, voltando a registrar índices superiores a $50 \%$ só após às $20: 00 \mathrm{~h}$. Dessa forma, pode-se observar que tratou de um dia extremamente seco.

O gráfico dos valores horários de radiação solar global seguiu a tendência dos dias precedentes com a continuidade da curva parabólica indicando céu claro. Os registros atingiram pico de $965 \mathrm{~W} / \mathrm{m}^{2}$, às $13: 00 \mathrm{~h}$, com média diária de $296 \mathrm{~W} / \mathrm{m}^{2}$, ao longo de 13 horas de insolação. A pressão atmosférica variou $4 \mathrm{mb}$, com pico de $933 \mathrm{mb}$, a partir das 10:30h permanecendo estável até às $12: 30 \mathrm{~h}$, retornando a este valor no final do dia, a partir das $23: 00 \mathrm{~h}$. A mínima registrada no final da tarde, às $16: 30 \mathrm{~h}$, foi de $930 \mathrm{mb}$.

Os ventos predominantes foram do quadrante NE, o que sugere o início do domínio da massa Tropical Atlântica sobre a região. Durante a manhã, houve a predominância de aragem e brisa leve do quadrante NE, com velocidades inferiores a $2,5 \mathrm{~m} / \mathrm{s}$. No período vespertino, entretanto, passaram a predominar os ventos dos quadrantes NW/W, caracterizando aragem com velocidade média de $1,5 \mathrm{~m} / \mathrm{s}$, porém com rajadas de brisa fraca de $4,2 \mathrm{~m} / \mathrm{s}$.

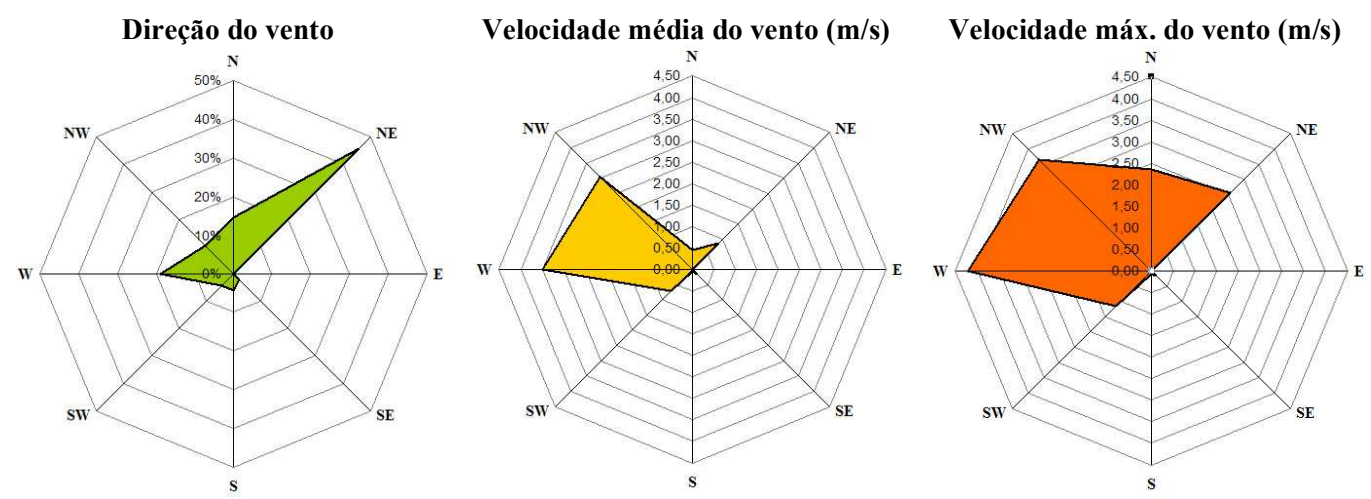

Figura 26: Rosa dos ventos com a dinâmica da circulação do ar no dia 23/02/2005, obtidos por meio de registros de direção e velocidade dos ventos tomados por média a cada 30 minutos pela estação automática localizada no Campus I. 
As condições sinóticas do dia 23/02/2005 podem ser atestadas pela imagem do canal infravermelho do satélite GOES 12 e pela carta de pressão ao nível do mar que mostram a permanência de um centro de baixa pressão sobre a região de São Carlos, evidenciando o domínio da massa Tropical Atlântica (Figura 27).

Nesse dia, o comportamento da temperatura do ar registrada nas quatro estações urbanas apresentou maiores diferenças durante a madrugada, no início da manhã e após às 20:00h, coincidindo, mais uma vez, com horários de ocorrência de calmaria. O céu claro, a baixa disponibilidade de vapor d'água na atmosfera e a reduzida ventilação proporcionaram maior definição na formação de ilhas de calor urbano.

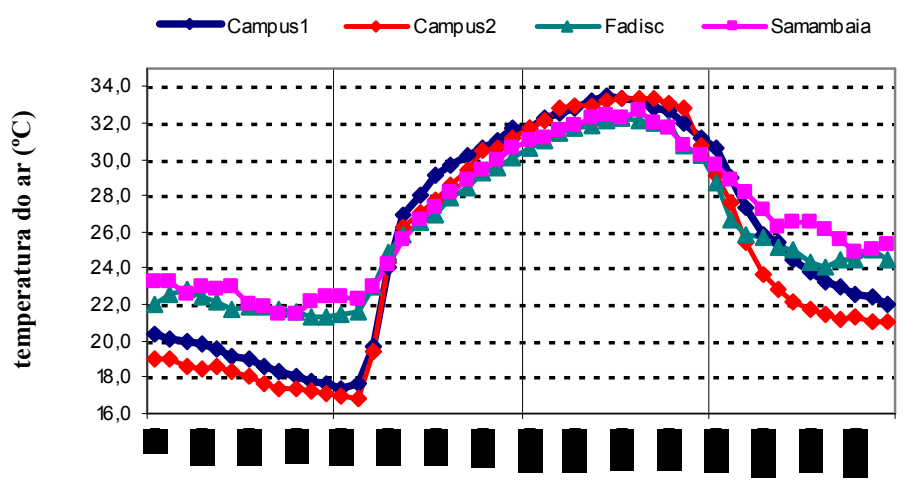

hora do dia (h)

Gráfico 12: Comportamento da temperatura do ar registrada no dia 23/02/2005 nas quatro estações urbanas.

Durante a madrugada, observou-se comportamento semelhante entre as estações no Campus I e no Campus II, com acentuada perda de radiação calorífica e menores temperaturas do ar. As mínimas de $17,4^{\circ} \mathrm{C}$ e $16,9^{\circ} \mathrm{C}$ foram registradas no Campus I e no Campus II, respectivamente, pouco após o nascer do Sol. O resfriamento observado nas estações na Fadisc e no Samambaia foi bastante reduzido durante a madrugada, apresentando comportamento diferente das estações no Campus I e no Campus II, porém semelhantes entre si. As temperaturas mínimas nessas estações foram registradas no nascer do Sol, com valores próximos a $21^{\circ} \mathrm{C}$, em ambas, o que resultou em diferenças de até $5,1^{\circ} \mathrm{C}$ entre as estações no Campus I e no Samambaia, às 6:30h.

Após o nascer do Sol, observou-se intenso aquecimento matinal nas estações no Campus I e no Campus II, conforme observado nos dias anteriores. O período de maior aquecimento nessas estações ocorreu entre 7:00h às 8:30h, com variação de temperatura superior a $9^{\circ} \mathrm{C}$, em ambas. No mesmo período de tempo, as estações na Fadisc e no Samambaia apresentaram variação de temperatura inferior a $4^{\circ} \mathrm{C}$. 
(a)

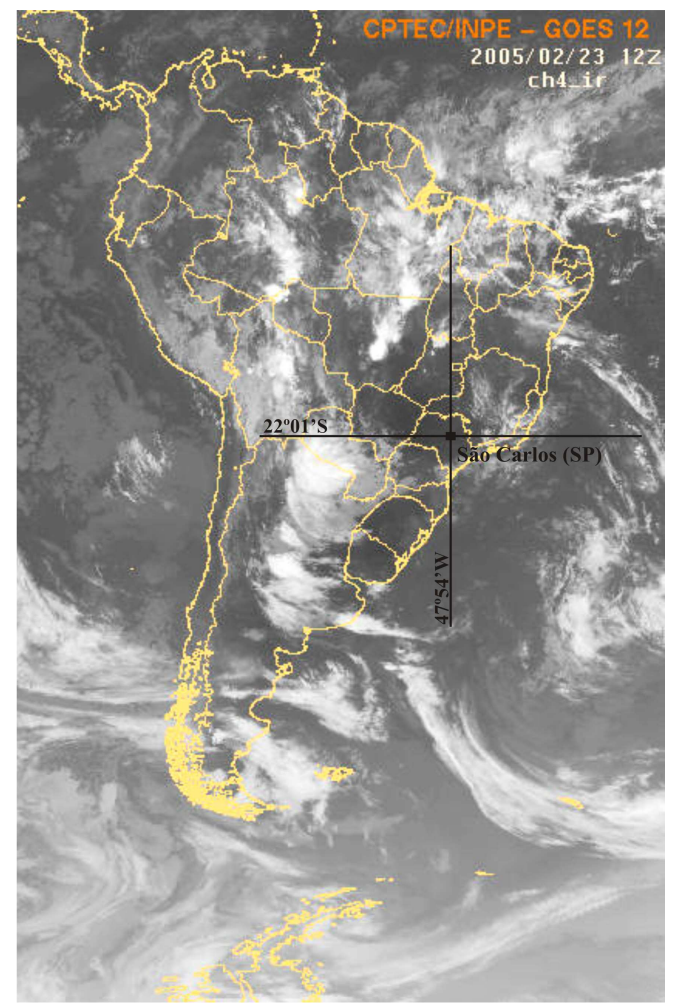

(b)

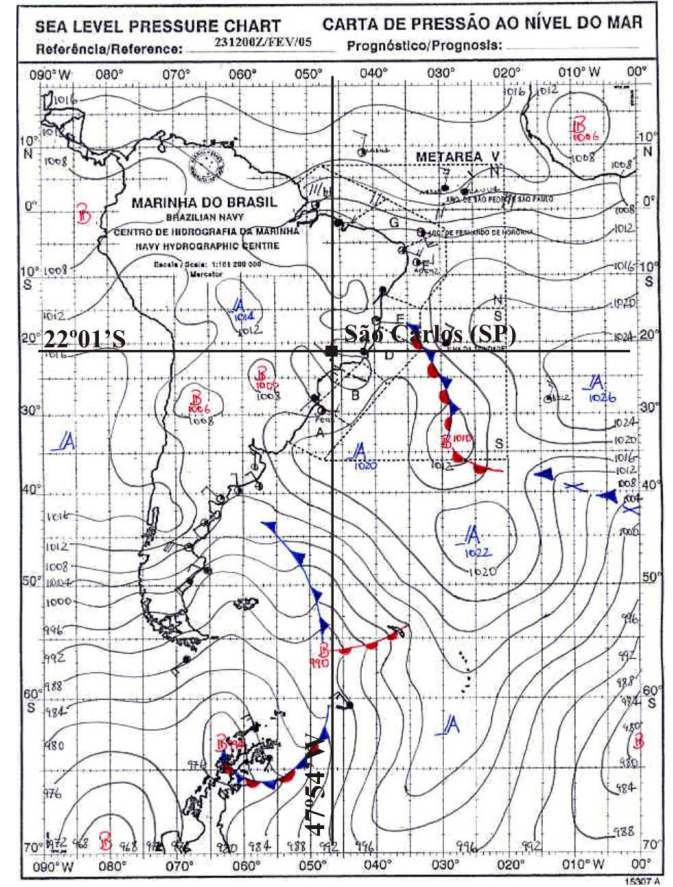

(c)
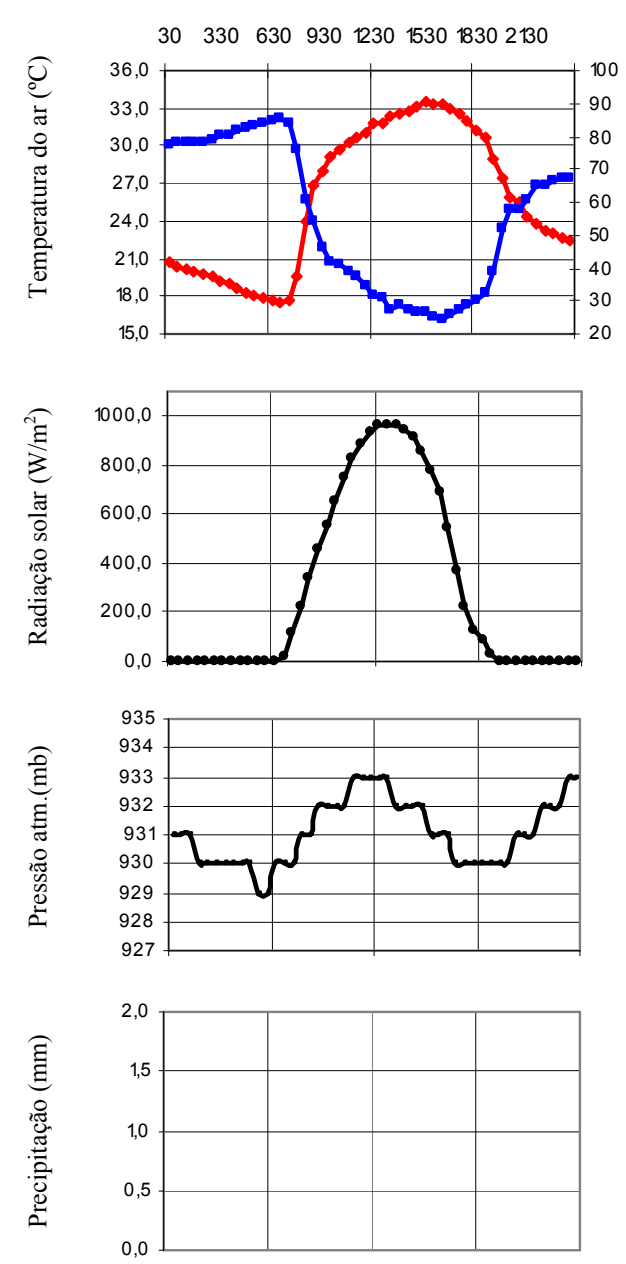

Direção do ar $\nearrow \nearrow \nearrow \nearrow \leftarrow \leftarrow \uparrow \nearrow$

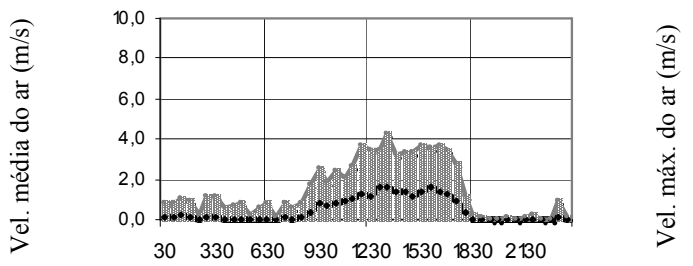

Legenda:

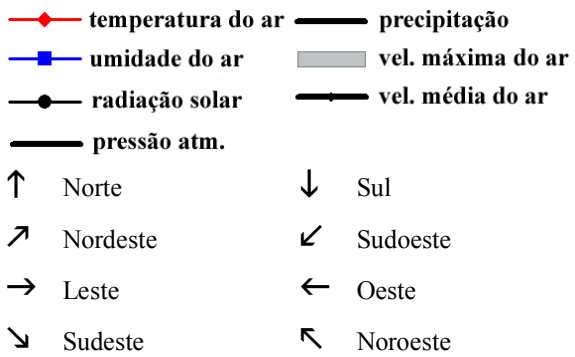

Figura 27: Imagem do satélite GOES-12, canal 4 (infravermelho), e carta de pressão ao nível do mar às 9:00h (horário local) do dia 23/02/2005 e análise rítmica horária com registro dos elementos climáticos tomados a cada 30 minutos. 
A partir das 9:00h, observou-se equilíbrio nos valores de temperatura do ar registrados em todas as estações, sugerindo a conformação de um campo térmico urbano mais homogêneo, possivelmente favorecido pela permanência de céu claro e pela baixa disponibilidade de vapor d'água na atmosfera que propiciou o aquecimento do ar nas quatro áreas monitoradas. O aquecimento do ar a partir desse horário deu-se de forma mais amena em todas as estações, até alcançar a temperatura máxima próximo às $15: 30 \mathrm{~h}$.

No período vespertino, todas as estações apresentam elevadas temperaturas do ar. Entretanto, após o pôr-do-sol, observou-se tendência de resfriamento em todas as estações, com destaque ao resfriamento acentuado ocorrido na estação no Campus II, também observado no dia anterior. A tendência de acentuado resfriamento após o pôr-do-sol observado nesse dia e no dia precedente deu-se pela combinação das seguintes condições atmosféricas: baixa umidade do ar, permanência de céu claro e ocorrência de calmaria, as quais favorecem a troca de energia calorífica por radiação entre as superfícies e a abóbada celeste.

Contudo, apesar das condições atmosféricas favoráveis a perda de calor armazenado pelas superfícies urbanas, observou-se que as estações na Fadisc e no Samambaia apresentaram reduzida perda de radiação calorífica após o pôr-do-sol, permanecendo com temperaturas do ar próxima aos $25^{\circ} \mathrm{C}$, o que resultou na reduzida amplitude térmica diárias observadas nessas duas estações $\left(10,9^{\circ} \mathrm{C}\right.$, na Fadisc; e $11,2^{\circ} \mathrm{C}$, no Samambaia) em relação à amplitude térmica diária observada nas outras duas estações $\left(16,1^{\circ} \mathrm{C}\right.$, no Campus I; e $16,5^{\circ} \mathrm{C}$, no Campus II).

O Gráfico 13 apresenta as diferenças de temperatura do ar observada entre as estações automáticas, duas a duas, ao longo o dia 23/02/2005. A partir da análise dos gráficos, observou-se tendência de aumento na diferença térmica entre as estações durante a madrugada, o que sugere a influência das propriedades físicas dos materiais constituintes do entorno urbano e da forma de ocupação do solo na troca noturna de energia calorífica com a abóbada celeste, visto que, nesse dia, durante a madrugada houve o predomínio de céu claro e calmaria.

Nesse sentido, observou-se acentuada diferença térmica durante a madrugada entre as estações no Campus I e na Fadisc, na ordem de $4,0^{\circ} \mathrm{C}$, e entre as estações no Campus I e no Samambaia, na ordem de $5,1^{\circ} \mathrm{C}$, ambas diferenças registradas ao nascer do Sol, às 6:30h. Entretanto, diferenças maiores foram registradas entre as estações no Campus II e na Fadisc $\left(4,7^{\circ} \mathrm{C}\right)$ e entre as estações no Campus II e no Samambaia $\left(5,5^{\circ} \mathrm{C}\right)$, pouco após o nascer do Sol, às 7:00h. As diferenças térmicas observadas nas estações urbanas pouco após o nascer do Sol deu-se, sobretudo, pela 
intensa perda de radiação calorífica durante a madrugada notada nas estações no Campus I e no Campus II - fato também observado no dia precedente.

Durante o período diurno, todas as estações apresentaram comportamentos semelhantes apresentando temperatura do ar elevada, resultado do intenso aquecimento das superfícies urbanas proporcionado pelas condições de céu claro, característico da fase de domínio da massa Tropical Atlântica, como mencionado anteriormente. Nesses horários, a diferença térmica entre as estações foram inferiores a $1,4^{\circ} \mathrm{C}$ - máxima registrada entre as estações no Campus I e na Fadisc, às 15:00h.

a)

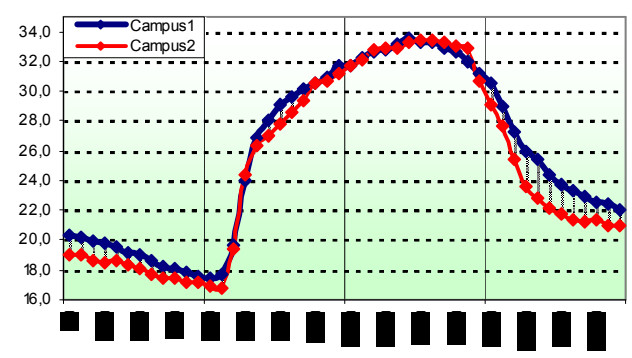

c)

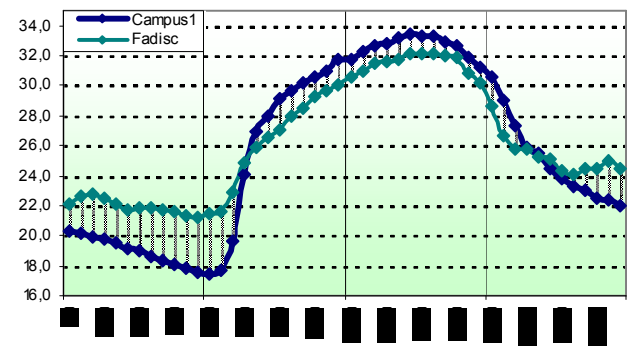

e)

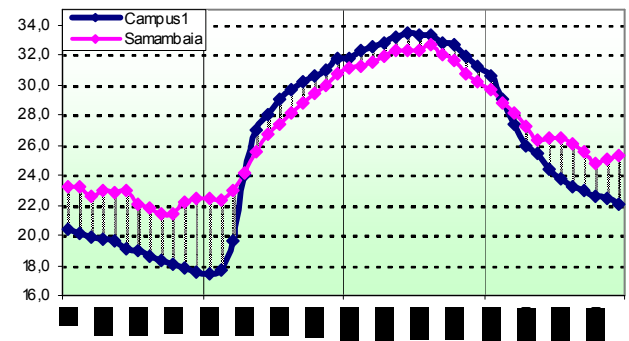

b)

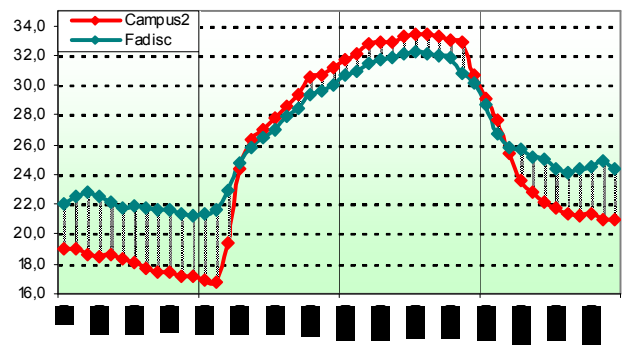

d)

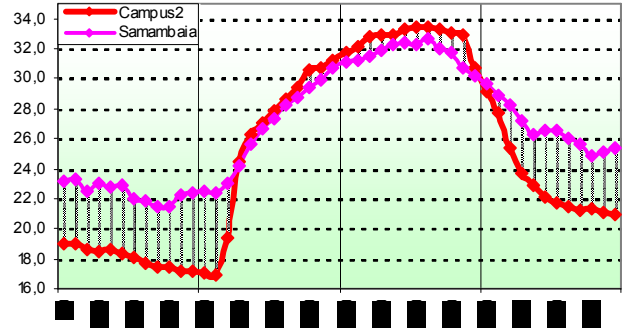

f)

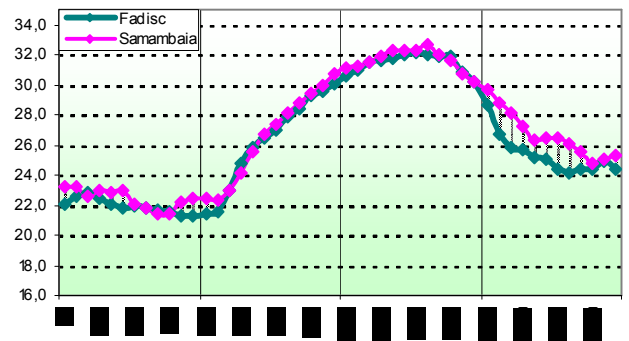

Gráfico 13: Diferenças no comportamento da temperatura do ar registrada no dia 23/02/2005 nas quatro estações urbanas, analisadas duas a duas.

As diferenças de temperatura do ar entre as estações após o pôr-do-sol apresentaram comportamento e valores semelhantes aos observados no dia anterior. As maiores diferenças térmicas nesses horários foram registradas entre as estações no Campus II e no Samambaia, na ordem de $4,7^{\circ} \mathrm{C}$, às $21: 30 \mathrm{~h}$, e entre as estações no Campus II e na Fadisc, na ordem de $3,9^{\circ} \mathrm{C}$, às $23: 30 \mathrm{~h}$. Essas diferenças térmicas tenderam a aumentar durante a madrugada, culminando na diferença máxima ao nascer do Sol. 
A leitura horizontal da matriz de análise (Gráfico 14) permitiu observar o desempenho térmico das quatro estações urbanas ao longo do dia. Os gráficos do Campus I apresentou variação entre os períodos diurnos e noturnos, mantendo-se menos aquecido do que as estações na Fadisc e no Samambaia durante a madrugada e após o pôr-do-sol, como também foi observado no dia precedente. Entretanto, durante o período diurno a estação no Campus I apresentou maior aquecimento em relação às mesmas estações, com exceção da estação no Campus II, à qual apresentou comportamento análogo.

Entre as estações no Campus I e no Campus II, mereceu atenção a diferença de temperatura do ar observada após o pôr-do-sol, apresentando pico de $2,6^{\circ} \mathrm{C}$, às 20:30h. Esse fato também foi observado no dia precedente, sugerindo comportamento regular na fase de domínio da massa Tropical Atlântica. O pico de diferença entre as duas estações deu-se pela intensa perda de radiação calorífica notada no Campus II pouco tempo após o pôr-do-sol. Contudo, após o pico de diferença de temperatura, observou-se tendência, em ambas as estações, em diminuir a diferença térmica e apresentar comportamento e valores de temperatura do ar semelhantes no decorrer da madrugada.

Com relação ao Campus II, a leitura horizontal dos gráficos comprovou a tendência em apresentar comportamento semelhante ao observado na estação no Campus I, chegando a apresentar diferenças nulas no período vespertino. Notou-se, ainda, a intensa diferença de temperatura do ar entre essa estação e as estações na Fadisc e no Samambaia, sobretudo durante a madrugada e após o pôr-do-sol, com ocorrência de calmaria.

A leitura horizontal dos gráficos das estações na Fadisc e no Samambaia mostraram a intensa diferença de temperatura do ar entre essas duas estações e as estações no Campus I e no Campus II, especialmente durante a madrugada e após o pôr-do-sol, como observado anteriormente. Observou-se, ainda, que as estações na Fadisc e no Samambaia apresentaram comportamento análogo durante todo o dia, com pequena diferença térmica após o pôr-do-sol, devido ao perda de radiação calorífica mais lenta observada na estação do Samambaia. 


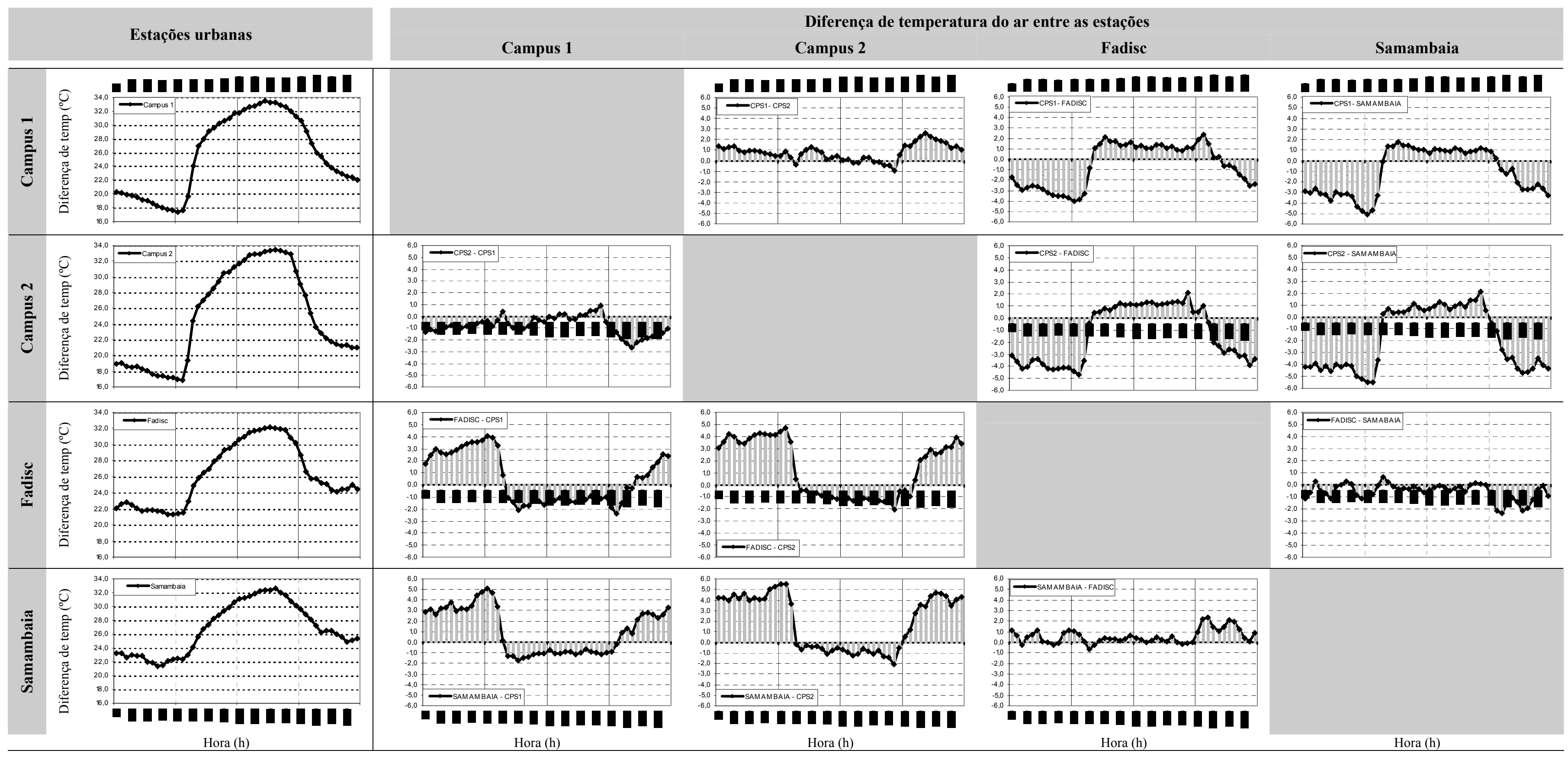

Gráfico 14: Matriz de análise do comportamento térmico das quatro estações automáticas no dia 23/02/2005. A leitura horizontal dos gráficos permite acompanhar o comportamento diário de cada estação em relação às demais, indicando maior ou menor aquecimento do ar de acordo com a projeção acima ou abaixo do eixo das coordenadas, respectivamente, enquanto a leitura vertical dos gráficos permite a análise das estaçôes automáticas tomadas a partir de uma estação de referência, indicada acima de cada coluna. 


\section{FASE DE PRENÚNCIO}

A fase de prenúncio compreendeu o dia 24 de fevereiro de 2005 . No dia 25 o domínio da Tropical Atlântica foi interrompido pelo avanço de um sistema frontal de fraca intensidade.

\section{- Dia 24 de fevereiro de 2005}

No dia 24/02/2005 permaneceu a tendência de elevada amplitude térmica diária observada nos dias de domínio da massa Tropical Atlântica, da ordem de $14,9^{\circ} \mathrm{C}$, seguido do aumento da média dos valores de temperatura do ar diária, proporcionado pela permanência de céu claro. Nesse dia foi registrada a maior máxima da temperatura do ar do verão em $2005-34,0^{\circ} \mathrm{C}$, às $14: 00 \mathrm{~h}$, e os índices de umidade relativa do ar seguiram a tendência do dia anterior, registrando-se abaixo dos $50 \%$ a partir das $9: 00 \mathrm{~h}$, com mínima de $29 \%$ ocorrendo próximo ao horário de maior aquecimento do ar, às 13:30h.

Dessa forma, pode-se caracterizar o dia 24/02/2005 como um dia extremamente quente e seco. A radiação solar global atingiu o maior pico do período analisado, chegando a $1007 \mathrm{~W} / \mathrm{m}^{2}$, às $13: 00 \mathrm{~h}$, com média diária de $258 \mathrm{~W} / \mathrm{m}^{2}$, ao longo de 13 horas de insolação. Entretanto, observa-se a presença de alguma nebulosidade a partir das 15:00h, possivelmente conseqüência da aproximação de um sistema frontal sobre a região. A pressão atmosférica variou $3 \mathrm{mb}$, com pico de $934 \mathrm{mb}$, a partir das 9:00h permanecendo estável até às 13:00h. A mínima ocorreu próximo ao final da tarde - 931mb, às 16:00h - permanecendo estável até às 20:00h.

Os ventos predominantes foram do quadrante $\mathrm{NE}$, indicando o domínio da massa Tropical Atlântica sobre a região. Durante o período matutino, sopraram brisa leve e brisa fraca do $\mathrm{NE}$, com rajadas de até $3,5 \mathrm{~m} / \mathrm{s}$. Durante à tarde, houve a predominância de brisa fraca com rajadas de $3,5 \mathrm{~m} / \mathrm{s}$ do quadrante $\mathrm{W}$, alterando à noite para a direção SE.

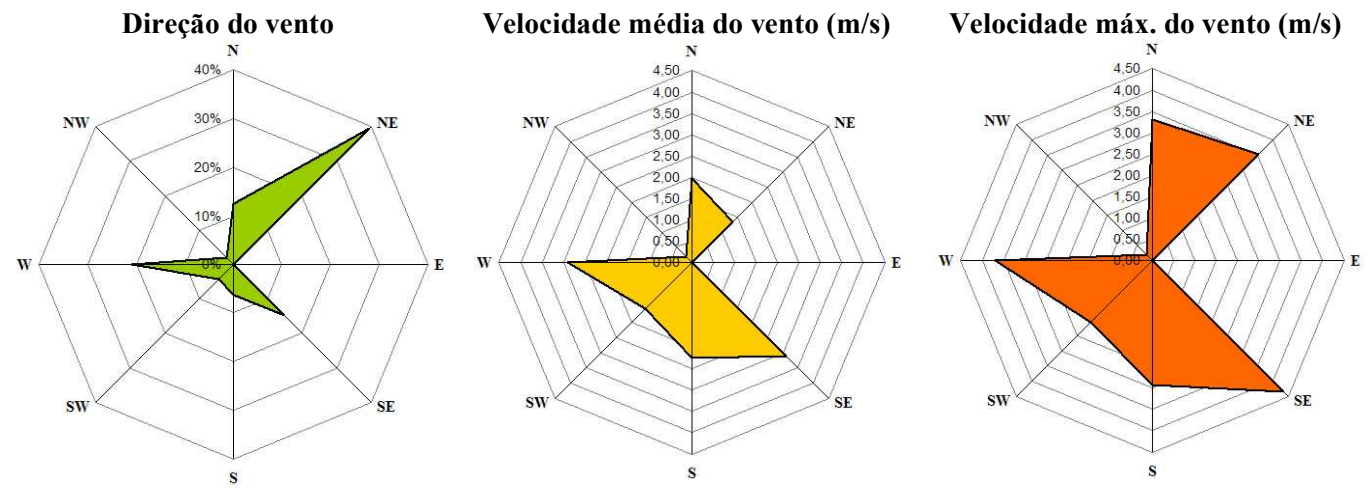

Figura 28: Rosa dos ventos com a dinâmica da circulação do ar no dia 24/02/2005, obtidos por meio de registros de direção e velocidade dos ventos tomados por média a cada 30 minutos pela estação automática localizada no Campus I. 
(a)

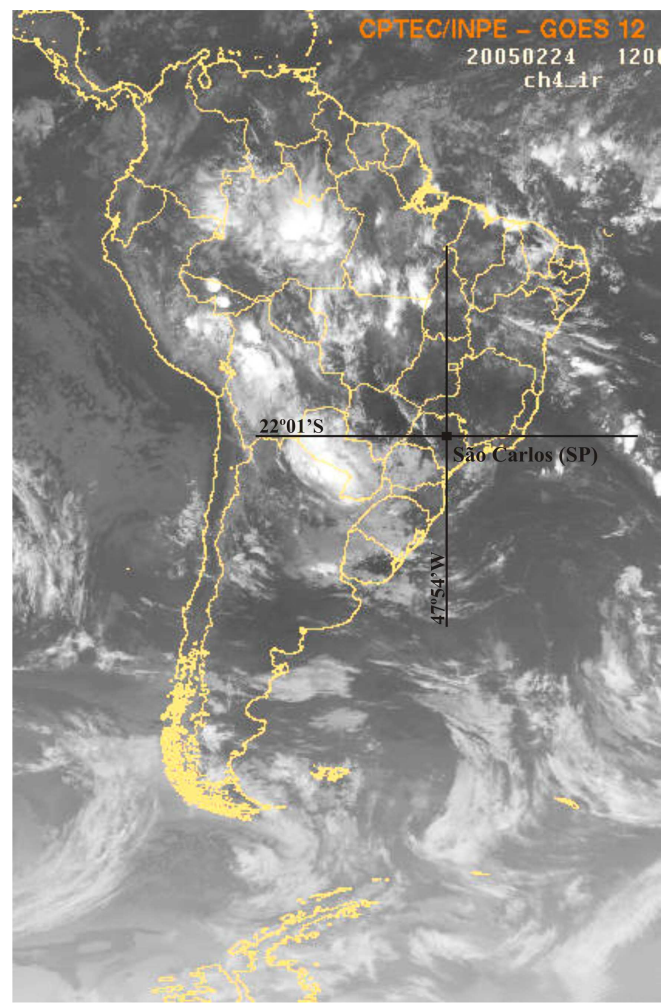

(b)

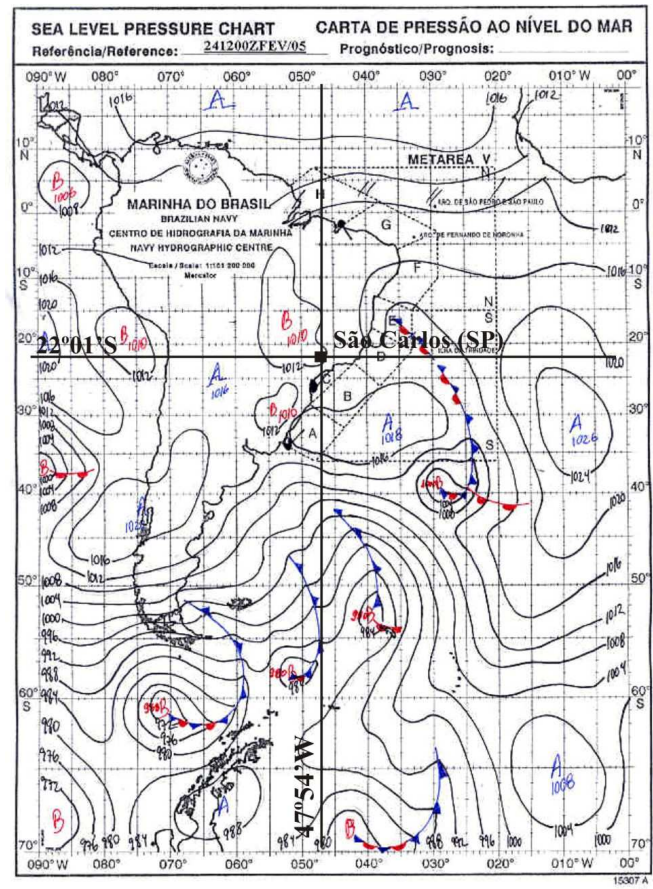

(c)

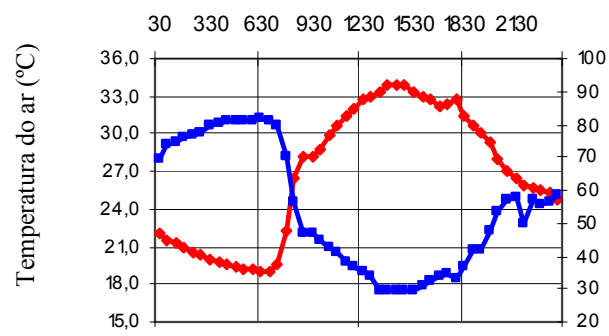

0
0
$\vdots$
0
0
$\frac{0}{\pi}$
$\frac{\pi}{0}$
0
0
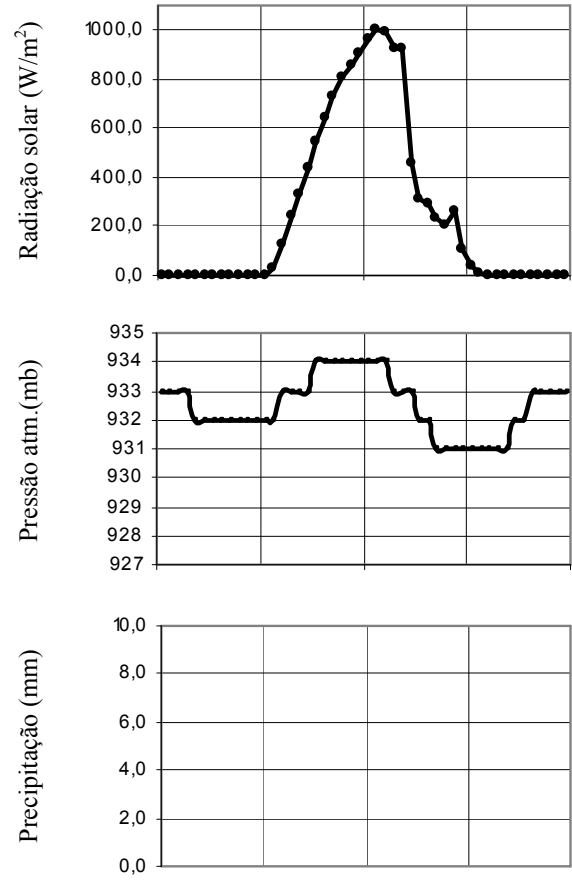

Direção do ar $\nearrow \nearrow \nearrow \nearrow \leftarrow \leftarrow \downarrow \searrow$

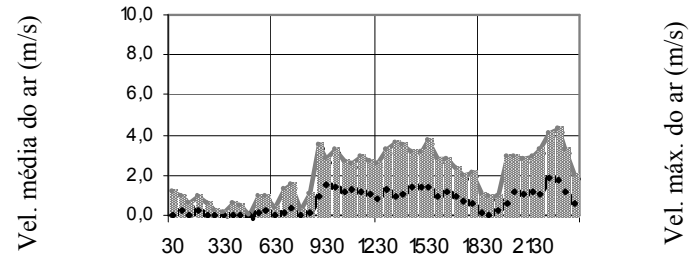

Legenda:

$$
\begin{array}{lll}
\longrightarrow \text { temperatura do ar } & \text { precipitação } \\
\longrightarrow \text { umidade do ar } & & \text { vel. máxima do ar } \\
\longrightarrow \text { radiação solar } & & \text { vel. média do ar } \\
\text { pressão atm. } & & \\
\nearrow \quad \text { Norte } & \downarrow & \text { Sul } \\
\rightarrow \quad \text { Lesdeste } & \swarrow \quad \text { Sudoeste } \\
\searrow \quad \text { Sudeste } & \leftarrow \text { Oeste }
\end{array}
$$

Figura 29: Imagem do satélite GOES-12, canal 4 (infravermelho), e carta de pressão ao nível do mar às 9:00h (horário local) do dia 24/02/2005 e análise rítmica horária com registro dos elementos climáticos tomados a cada 30 minutos. 
Nesse dia, o comportamento da temperatura do ar registrada nas quatro estações urbanas apresentou-se similar ao comportamento observado no dia anterior, com as maiores diferenças no início da manhã, coincidindo, mais uma vez, com o período de ocorrência de calmaria.

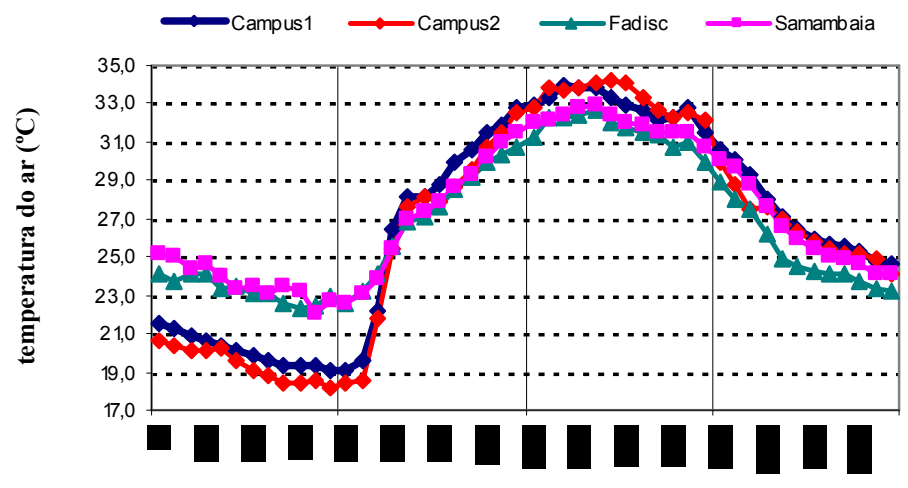

hora do dia (h)

Gráfico 15: Comportamento da temperatura do ar registrada no dia 24/02/2005 nas quatro estações urbanas.

Durante a madrugada o comportamento da temperatura do ar foi similar entre as estações no Campus I e no Campus II, com acentuada perda de radiação calorífica e menores temperaturas do ar, com mínimas de $19,1^{\circ} \mathrm{C}$ e $18,2^{\circ} \mathrm{C}$, respectivamente, pouco após o nascer do Sol. Esse comportamento também foi observado nos dois dias precedentes, o que sugeriu comportamento peculiar dessas estações sob as condições de céu claro e calmaria.

O resfriamento observado nas estações na Fadisc e no Samambaia, durante a madrugada, novamente foi bastante reduzido, apresentando comportamento térmico contrário ao observado nas estações no Campus I e no Campus II, porém semelhantes entre si. As temperaturas mínimas nessas estações foram registradas no nascer do Sol, com valores próximos a $22^{\circ} \mathrm{C}$, em ambas.

Após o nascer do Sol, observou-se intenso aquecimento matinal nas estações no Campus I e no Campus II, conforme observado nos dias anteriores. O período de maior aquecimento nessas estações ocorreu entre $6: 30 \mathrm{~h}$ às $8: 30 \mathrm{~h}$, com variação de temperatura superior a $9^{\circ} \mathrm{C}$, em ambas. A partir das 9:00h houve tendência de equilíbrio nos valores de temperatura do ar, o que favoreceu a formação de um campo térmico urbano mais homogêneo. As máximas diária ocorreram mais próximo ao início da tarde, por volta das 14:30h, pouco antes da formação de forte nebulosidade, característica da fase de prenúncio. 
Após o pôr-do-sol, observou-se tendência de resfriamento em todas as estações. Diferente do comportamento observado na estação no Campus II nos dias precedentes, a perda noturna de radiação calorífica ocorreu de forma lenta e gradual em todas as estações, devido à intensa nebulosidade que dificultou a troca de energia calorífica por radiação entre as superfícies urbanas e a abóbada celeste.

O Gráfico 16 apresenta as diferenças de temperatura do ar observada entre as estações automáticas, duas a duas, ao longo o dia 24/02/2005. A partir da análise dos gráficos observou-se a tendência de elevada diferença térmica entre as estações durante a madrugada, como notada nos dois dias precedentes. As maiores diferenças térmicas foram registradas entre as estações no Campus II e na Fadisc, na ordem de $4,7^{\circ} \mathrm{C}$, às $6: 00 \mathrm{~h}$, e entre as estações no Campus II e no Samambaia, na ordem de $5,0^{\circ} \mathrm{C}$, às $4: 30 \mathrm{~h}$. Diferenças significativas também foram observadas entre as estações no Campus I e na Fadisc $\left(3,8^{\circ} \mathrm{C}\right)$ e entre as estações no Campus I e no Samambaia $\left(3,7^{\circ} \mathrm{C}\right)$, ambas às $6: 00 \mathrm{~h}$. Observou-se, ainda, que as estações no Campus I e no Campus II não apresentaram diferenças térmicas entre si durante a madrugada, assim como observado entre as estações na Fadisc e no Samambaia - fato observado também nos dias 22 e 23/02/2005.

a)

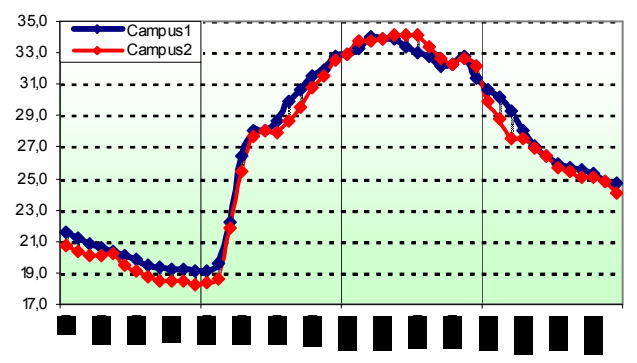

c)

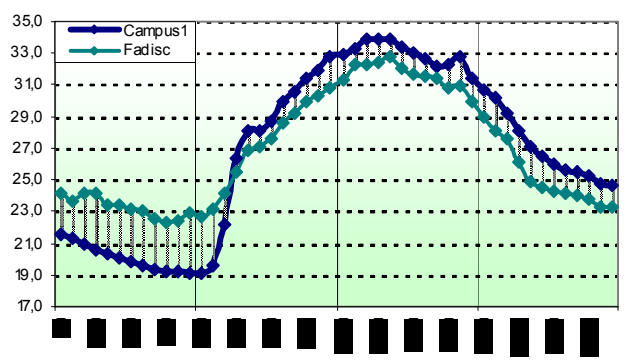

e)

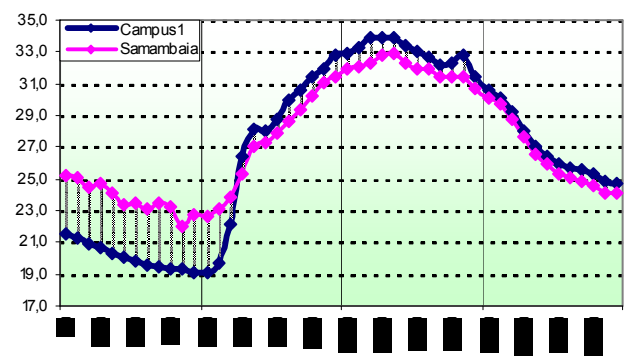

b)

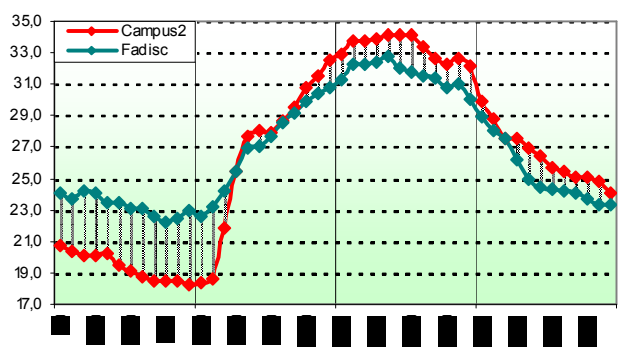

d)

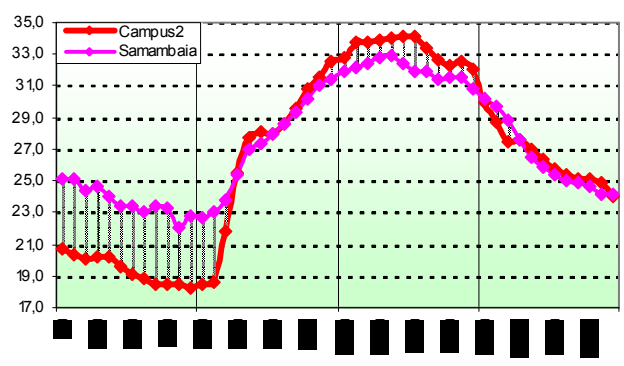

f)

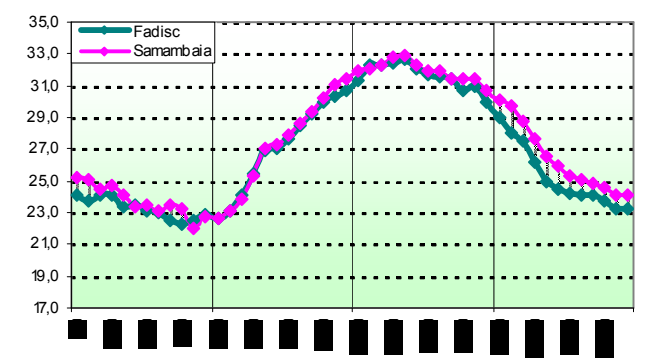

Gráfico 16: Diferenças no comportamento da temperatura do ar registrada no dia 24/02/2005 nas quatro estações urbanas, analisadas duas a duas. 
Esses resultados foram análogos aos observados no dia anterior, sugerindo que esse comportamento pode ser característico nas estações analisadas na fase de domínio da massa Tropical Atlântica, devido à ocorrência de céu claro e calmaria.

Durante o período vespertino, observou-se pequeno incremento na diferença térmica entre as estações, devido ao aumento da temperatura do ar diária. A maior diferença na temperatura do ar foi registrada entre as estações no Campus II e na Fadisc, na ordem de $2,4^{\circ} \mathrm{C}$, às $15: 30 \mathrm{~h}$. Também se notou diferenças significativas entre as estações no Campus II e no Samambaia $\left(2,1^{\circ} \mathrm{C}\right)$, às $15: 30 \mathrm{~h}$. O horário no qual foram registradas essas diferenças coincide com o momento de diminuição da incidência de radiação solar direta devido à presença de nebulosidade a partir das 15:00h.

Durante o período noturno, todas as estações apresentaram comportamento análogo registrando diferenças térmicas pequenas entre si devido a forte nebulosidade que dificultou a perda de energia calorífica para a abóbada celeste após o pôr-do-sol. Nesse sentido, as diferenças térmicas registradas foram inferiores a $2,2^{\circ} \mathrm{C}$ - diferença máxima, registrada entre as estações no Campus I e na Fadisc, às 20:30h. Nesse mesmo horário, observou-se diferença térmica de $2,0^{\circ} \mathrm{C}$ entre as estações no Campus Il e na Fadisc.

A leitura horizontal da matriz de análise (Gráfico 17) permitiu observar o desempenho térmico nas quatro estações urbanas analisadas. Os gráficos do Campus I mostraram as intensas diferenças térmicas entre essa estação e as estações na Fadisc e no Samambaia durante a madrugada. Diferenças de intensidade semelhantes, nesses horários, também foram observadas entre a estação no Campus Il e as estações na Fadisc e no Samambaia.

A leitura dos gráficos também permitiu observar que, após o nascer do Sol, a diferença de temperatura do ar entre as estações diminuiu de forma significativa, evidenciando que todas as estações apresentaram comportamento análogo no período de incidência da radiação solar direta, apresentando pequenas diferenças de temperatura do ar, o que indicou maior homogeneidade no campo térmico urbano.

Observou-se, ainda, que no período noturno as estações apresentaram pequenas diferenças de temperatura do ar devido à forte nebulosidade característica da fase de prenúncio, indicando permanência na homogeneidade do campo térmico após o pôr-do-sol. Esse fato rompeu com a tendência do comportamento térmico observado nos dias precedentes, que indicava formação de ilhas de calor urbana em algumas áreas da cidade. 
Nesse sentido, as maiores diferenças térmicas foram observadas apenas no período da madrugada, sob condições atmosféricas de céu claro, com alternância de períodos de calmaria e aragem, quando houve indícios de ilhas de calor urbana nas áreas da Fadisc e do Samambaia, porém com temperaturas inferiores a $24^{\circ} \mathrm{C}$.

Por fim, observou-se o comportamento térmico semelhante entre as estações no Campus I e no Campus II, assim como entre as estações na Fadisc e no Samambaia, ao longo do dia, expresso nos gráficos da matriz de análise (Gráfico 27) pela maior proximidade dos pontos projetados próximo ao eixo das abcissas e nos gráficos de diferenças de térmica entre as estações (Gráfico 24 ) pela sobreposição dos valores de temperatura do ar registradas nessas estações urbanas.

\section{FASE DE AVANÇO DO SISTEMA FRONTAL}

\section{- Dia 25 de fevereiro de 2005}

No dia 25/02/2005 houve o avanço do quinto sistema frontal sobre a região, conforme atestado pelo Boletim Climanálise (CLIMANÁLISE, 2005). Neste sentido, pode-se dividir a análise deste dia em dois momentos: antes e após o avanço da frente Polar Atlântica sobre a região de estudo.

Antes da entrada da Frente Polar Atlântica, os valores de temperatura do ar seguiram a tendência de elevação registrada no dia anterior. Durante a madrugada a temperatura chegou à mínima de $23,2^{\circ} \mathrm{C}$, às $4: 30 \mathrm{~h}$, iniciando tendência de elevação ao nascer do Sol até alcançar a máxima de $32,7^{\circ} \mathrm{C}$, às $13: 30 \mathrm{~h}$, com registro de amplitude térmica de $12,1^{\circ} \mathrm{C}$, ainda que apresentando céu parcialmente encoberto.

Os índices de umidade relativa do ar também seguiram a tendência do dia anterior, apresentando-se abaixo dos $50 \%$ poucas horas antes da entrada do sistema frontal, alcançando o mínimo de $40 \%$ no horário de maior aquecimento do ar, às 13:30h. Porém, esse quadro alterou-se após o avanço do sistema frontal sobre a região.

A entrada da Frente Polar Atlântica sobre a região de São Carlos ocorreu aproximadamente às $15: 00 \mathrm{~h}$. No momento da entrada da frente, registrou-se brusca queda no valor da temperatura do ar, com amplitude de $3,9^{\circ} \mathrm{C}$ em poucos minutos, e, conseqüentemente, acentuado aumento no índice de umidade relativa do ar, chegando a $84 \%$, às $16: 30 \mathrm{~h}$. O avanço do sistema frontal sobre a região foi acompanhado de fraca precipitação $(0,76 \mathrm{~mm})$, voltando a chover à noite e durante a madrugada. 


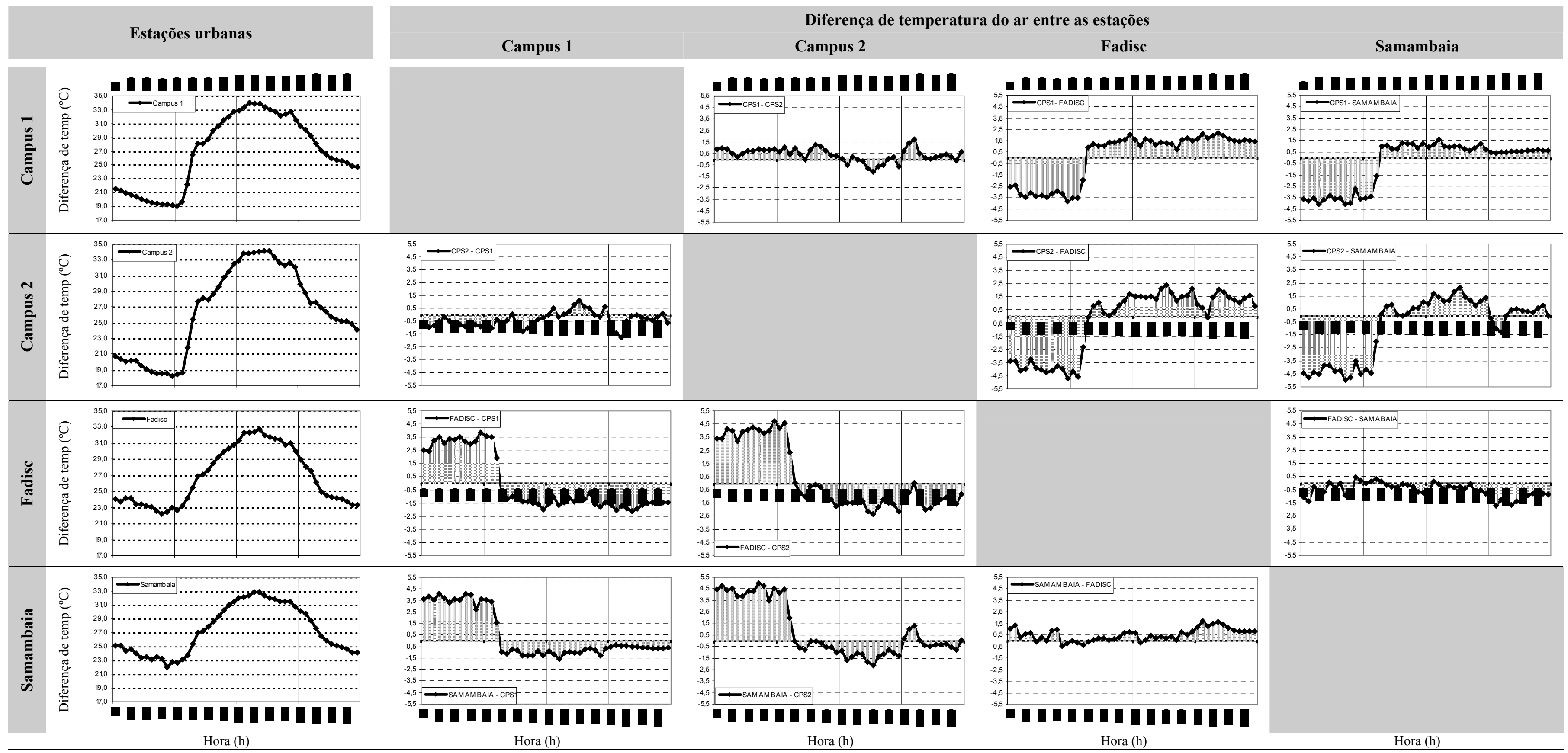

Gráfico 17: Matriz de análise do comportamento térmico das quatro estações automáticas no dia 24/02/2005. A leitura horizontal dos gráficos permite acompanhar o comportamento diário de cada estação em relação às demais, indicando maior ou menor aquecimento do ar de acordo com a projeção acima ou abaixo do eixo das coordenadas, respectivamente, enquanto a leitura vertical dos gráficos permite a análise das estações automáticas tomadas a 
O gráfico irregular dos valores de radiação solar global indicou céu parcialmente encoberto, com forte cobertura de nuvens após a entrada da frente. $A$ radiação solar apresentou baixos valores durante todo o dia, com média diária de $169,2 \mathrm{~W} / \mathrm{m}^{2}$, ao longo de 13 horas de insolação, devido à nebulosidade. O maior pico ocorreu às $13: 00 \mathrm{~h}$, alcançando $949 \mathrm{~W} / \mathrm{m}^{2}$, porém apresentando-se como um evento momentâneo.

A pressão atmosférica registrou máxima de 933mb a partir das 9:00h, permanecendo estável até às 12:00h. Após a entrada da frente, observou-se diminuição dos valores da pressão atmosférica, com mínima de $928 \mathrm{mb}$, a partir das 16:30h. Vecchia (1997) salientou que a amplitude de $5 \mathrm{mb}$ nos valores diários da pressão atmosférica, como encontrada no dia 25/02/2005, é pouco habitual, ocorrendo apenas nos períodos pré-frontais que antecedem a penetração da Frente Polar Atlântica sobre a região.

Antes da entrada da frente, os ventos predominantes foram do quadrante NE, alternando entre aragem e brisa leve, com velocidades inferiores a $2,7 \mathrm{~m} / \mathrm{s}$. No momento da entrada da frente sobre a região, os ventos dominantes passaram a soprar do quadrante $\mathrm{W}$, possivelmente devido à formação de calhas induzidas, com rajadas de $5,2 \mathrm{~m} / \mathrm{s}$. Os ventos do quadrante $\mathrm{W}$ permaneceram predominantes após a entrada da frente, atingindo rajadas de $8,9 \mathrm{~m} / \mathrm{s}$ após às $22: 00 \mathrm{~h}$.
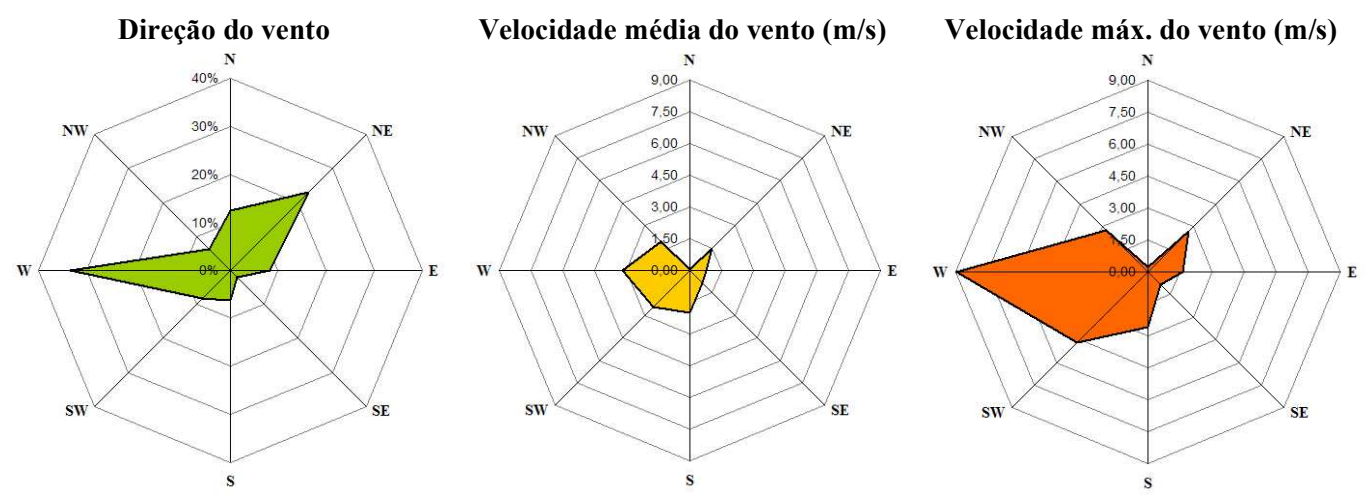

Figura 30: Rosa dos ventos com a dinâmica da circulação do ar no dia 25/02/2005, obtidos por meio de registros de direção e velocidade dos ventos tomados por média a cada 30 minutos pela estação automática localizada no Campus I.

Dessa forma, observou-se que o cenário atmosférico apresentou instabilidade após o avanço do sistema frontal, com forte nebulosidade e ocorrência de fraca precipitação. A acentuada queda nos valores da temperatura do ar e aumento no índice de umidade relativa do ar no momento de entrada da Frente Polar Atlântica caracterizaram a fase de avanço sobre a região. 
A imagem do canal infravermelho do satélite GOES-12 atesta a forte nebulosidade sobre a região de São Carlos, ao tempo que a carta de pressão ao nível do mar evidencia o avanço do centro de alta pressão sobre o Sudeste brasileiro (Figura 31).

Nesse dia, o comportamento da temperatura do ar registrada nas quatro estações urbanas apresentou-se bastante semelhantes entre si, indicando homogeneidade no campo térmico urbano durante todo o dia. A presença de nebulosidade desde a tarde do dia anterior, característica da fase de prenúncio, dificultou a troca de energia calorífica entre as superfícies urbanas e a abóboda celeste durante a madrugada e reduziu a incidência de radiação solar direta durante o dia, diminuindo a quantidade de energia absorvida pelas superfícies urbanas.

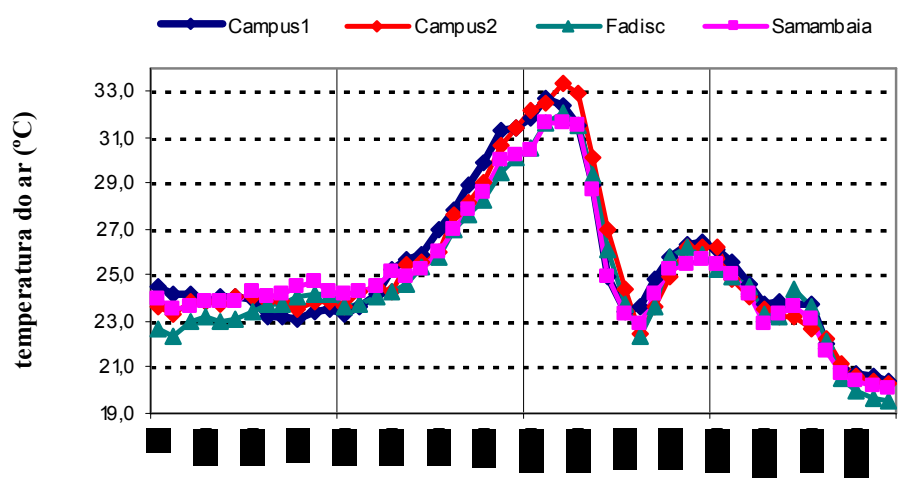

hora do dia (h)

Gráfico 18: Comportamento da temperatura do ar registrada no dia 25/02/2005 nas quatro estações urbanas.

Durante a madrugada, o comportamento das estações foi bastante homogêneo, mantendo-se praticamente estável até o nascer do Sol. Inversamente à tendência observada nas madrugadas precedentes com céu claro e perda de energia calorífica para a abóboda celeste, observou-se pequeno incremento na temperatura do ar entre às $0: 00 \mathrm{~h}$ e às $6: 30 \mathrm{~h}$, chegando a $1,6^{\circ} \mathrm{C}$ na estação na Fadisc, $0,9^{\circ} \mathrm{C}$ na estação no Samambaia e $0,5^{\circ} \mathrm{C}$ na estação no Campus II.

O incremento da temperatura do ar durante a madrugada possivelmente foi resultado da liberação de energia calorífica armazenada pelas nuvens durante a tarde anterior e ao calor armazenado pelas superfícies urbanas que, ao ser liberado por radiação para a atmosfera mais fria, permaneceu na camada intra-urbana devido à nebulosidade. A estação no Campus I foi a única a apresentar decréscimo no valor da temperatura do ar no mesmo período. 
(a)

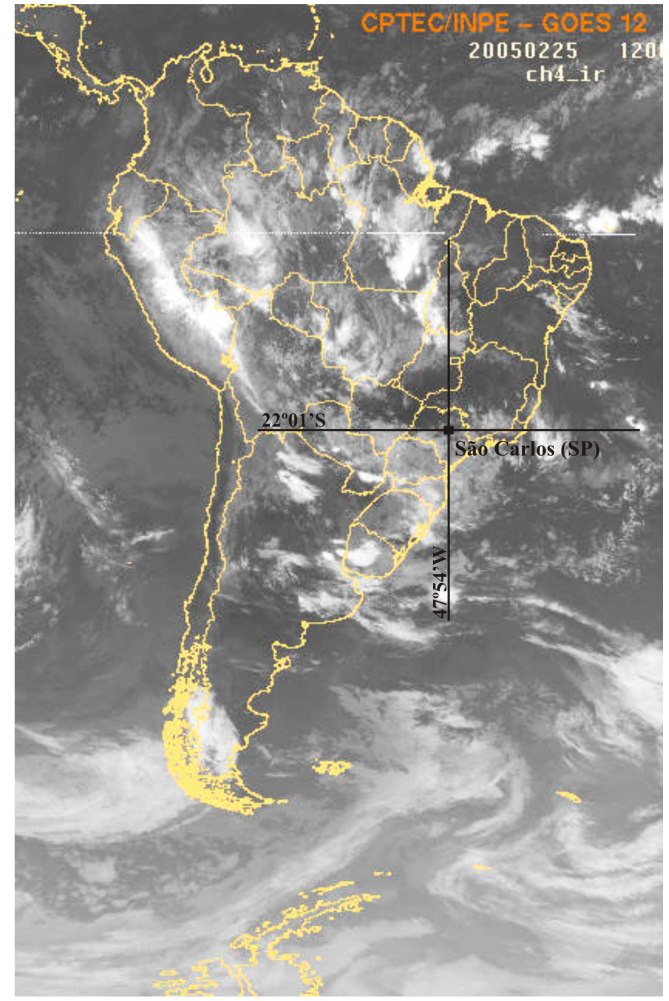

(b)

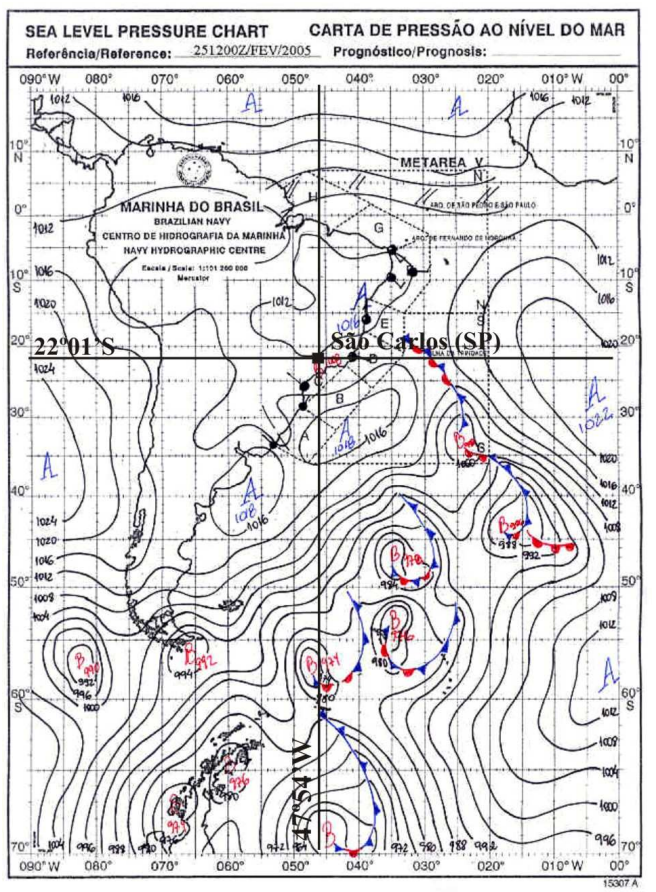

(c)
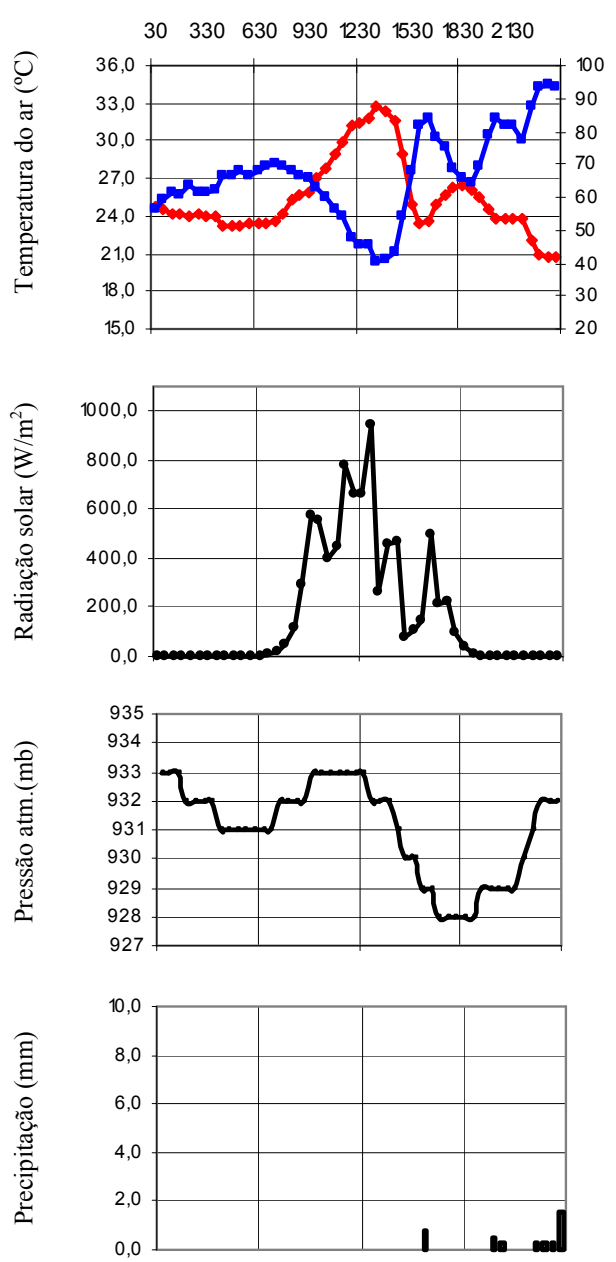

Direção do ar $\downarrow \uparrow \quad \nearrow \quad \nearrow \leftarrow \leftarrow \leftarrow \leftarrow$

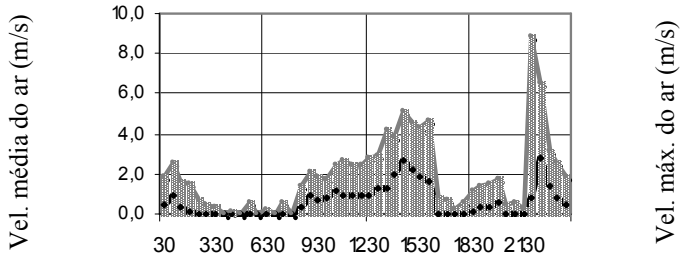

Legenda:

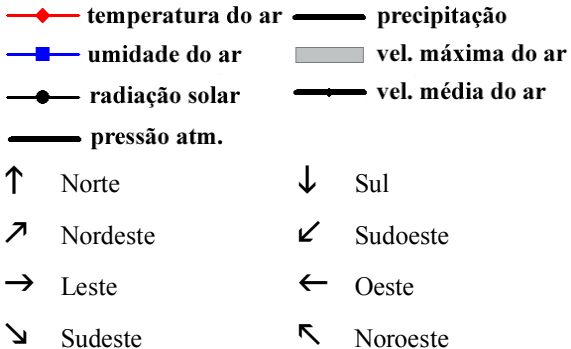

Figura 31: Imagem do satélite GOES-12, canal 4 (infravermelho), e carta de pressão ao nível do mar às 9:00h (horário local) do dia 25/02/2005 e análise rítmica horária com registro dos elementos climáticos tomados a cada 30 minutos. 
O aquecimento matinal ocorreu de forma gradual e contínua em todas as estações, mesmo nas estações no Campus I e no Campus II, que vinha apresentando aquecimento acentuado no início da manhã nos dias precedentes. O aquecimento mais lento nessas estações deve-se, principalmente, à nebulosidade que reduziu a incidência de radiação solar direta nesse dia. Entretanto, no final da manhã a diferença de temperatura entre as estações começou a se acentuar, devido à capacidade de absorção de calor pelos diferentes sítios. A temperatura máxima ocorreu no início da tarde em todas as estações, próximo às 13:00h, um pouco antes da entrada do sistema frontal sobre a região.

Após a entrada da frente Polar Atlântica, todas as estações apresentaram queda brusca nos valores da temperatura do ar, alcançando mínima próxima aos $23^{\circ} \mathrm{C}$, quando ocorreu precipitação. No final da tarde houve pequeno incremento na temperatura do ar, retornando à tendência de queda no início da noite. A ocorrência de precipitação com início às $22: 30$ h reduziu ainda mais a temperatura do ar em todas as estações analisadas no final da noite e início da madrugada do dia seguinte.

O Gráfico 19 apresenta as diferenças de temperatura do ar observada entre as estações automáticas, duas a duas, ao longo o dia 25/02/2005.

a)

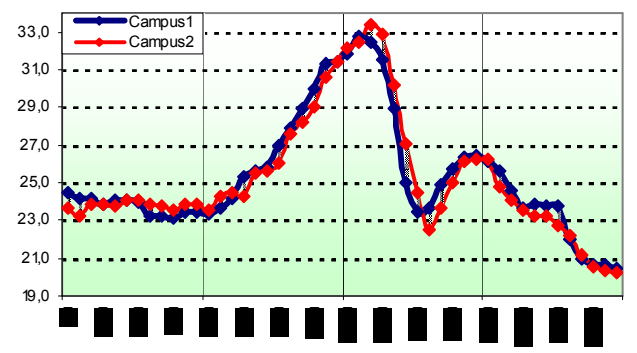

c)

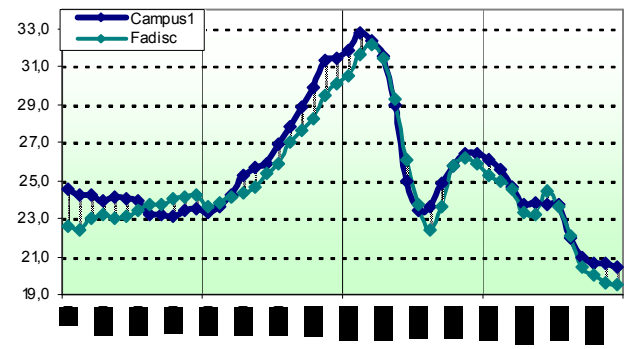

e)

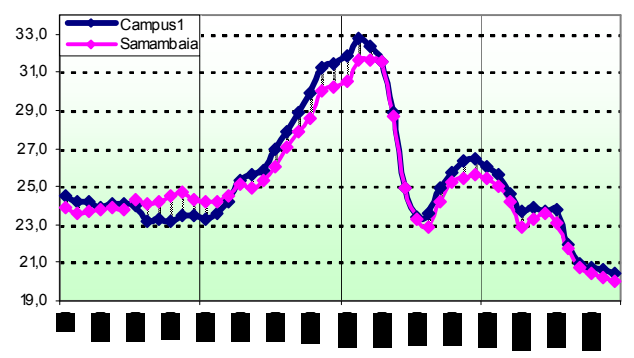

b)

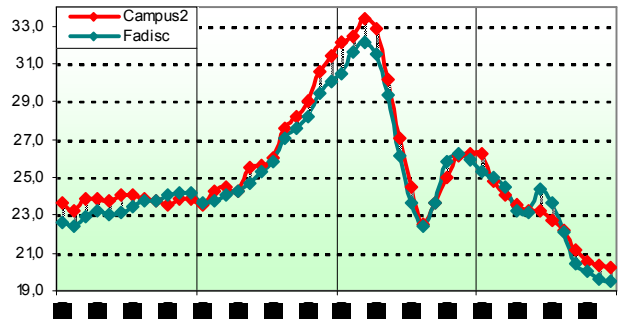

d)

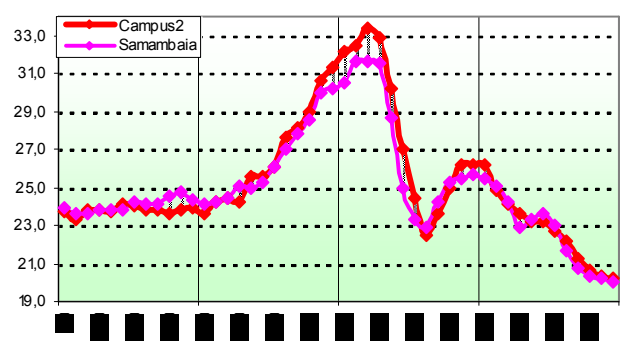

f)

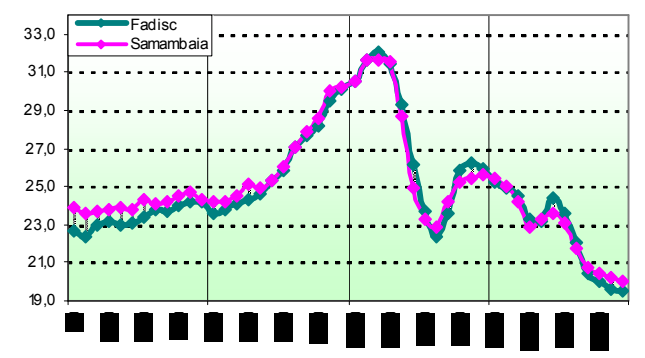

Gráfico 19: Diferenças no comportamento da temperatura do ar registrada no dia 25/02/2005 nas quatro estações urbanas, analisadas duas a duas. 


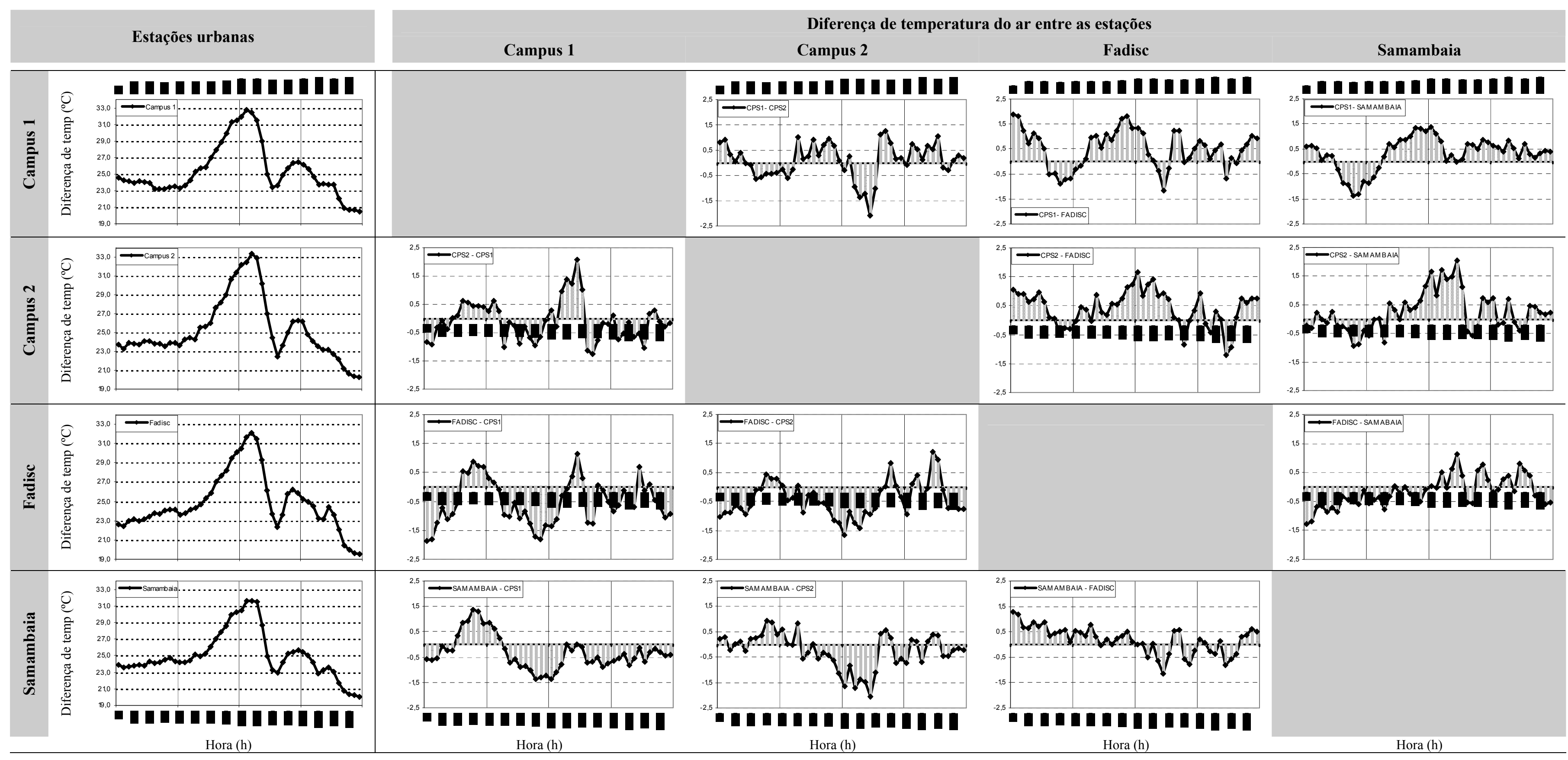

Gráfico 20: Matriz de análise do comportamento térmico das quatro estações automáticas no dia 25/02/2005. A leitura horizontal dos gráficos permite acompanhar o comportamento diário de cada estação em relação às demais, indicando maior ou menor aquecimento do ar de acordo com a projeção acima ou abaixo do eixo das coordenadas, respectivamente, enquanto a leitura vertical dos gráficos permite a análise das estaçôes automáticas tomadas a partir de uma estação de referência, indicada acima de cada coluna. 
A partir da análise dos gráficos observou-se que a nebulosidade presente nesse dia favoreceu, de forma significativa, à homogeneidade do campo térmico urbano ao longo do dia. As quatro estações urbanas analisadas apresentaram comportamento térmico semelhante, apresentando pequenas diferenças térmicas.

Durante a madrugada, a diferença máxima observada foi de $1,9^{\circ} \mathrm{C}$, registrada entre as estações no Campus I e na Fadisc, às 0:30h. Após esse horário, as diferenças de temperatura do ar entre as estações tenderam a aumentar até o nascer do Sol comportamento oposto ao observado nos dias precedentes.

O campo térmico permaneceu homogêneo durante todo o período vespertino. Entretanto, pequenas diferenças térmicas foram observadas no início da tarde, às 12:30h, entre as estações no Campus I e na Fadisc $\left(1,4^{\circ} \mathrm{C}\right)$, no Campus I e no Samambaia $\left(1,4^{\circ} \mathrm{C}\right)$, no Campus II e na Fadisc $\left(1,6^{\circ} \mathrm{C}\right)$ e no Campus II e no Samambaia $\left(1,7^{\circ} \mathrm{C}\right)$.

Após a entrada do sistema frontal sobre a região, as diferenças térmicas entre as estações tenderam novamente a nulidade. A precipitação ocorrida no final da noite favoreceu a permanência da homogeneidade do campo térmico no período noturno.

A leitura horizontal da matriz de análise (Gráfico 20) permitiu observar o desempenho térmico das quatro estações urbanas analisadas. A grande variação nos gráficos traduziu a instabilidade do cenário atmosférico na fase de avanço de um sistema frontal sobre a região.

As maiores diferenças entre as estações ocorreram pouco tempo antes do momento de entrada da frente, como era previsto, evidenciando diferenças nas respostas térmicas que cada área apresentou de acordo com as características de seu entorno construído. As estações no Campus I e no Campus II apresentaram ar mais aquecido com relação às outras duas estações, entretanto, as diferenças térmicas foram reduzidas, próximas a $2^{\circ} \mathrm{C}$, devido à forte nebulosidade. No momento do avanço do sistema frontal, a temperatura do ar em todas as estações tendeu à queda, apresentando diferenças térmicas inferiores à $0,8^{\circ} \mathrm{C}$.

\section{FASE DE DOMÍNIO DA MASSA POLAR ATLÂNTICA}

O sistema frontal que avançou sobre a região de São Carlos no dia 25/02/2005 foi de fraca intensidade. Dessa forma, o domínio da massa Polar Atlântica por dois dias: 26 e 27/02/2005, imprimindo com menos rigor suas características no cenário atmosférico na região. 


\section{- Dia 26 de fevereiro de 2005}

O dia 26/02/2005 permaneceu sobre o domínio da massa Polar Atlântica, que avançou sobre a região no dia anterior. A amplitude térmica diária foi reduzida, na ordem de $6,2^{\circ} \mathrm{C}$, com máxima de $25,9^{\circ} \mathrm{C}$, às $13: 00 \mathrm{~h}$, e mínima de $19,7^{\circ} \mathrm{C}$, pouco após o nascer do Sol, às 7:00h. A mínima diária próxima aos $20^{\circ} \mathrm{C}$ indicou que a massa Polar Atlântica que avançou sobre a região foi de fraca intensidade.

Os índices de umidade relativa do ar atestaram significativo aumento na disponibilidade de vapor d'água na atmosfera oriundo da massa Polar Atlântica que passou a controlar as condições atmosféricas sobre a região. Os valores registrados permaneceram acima dos $70 \%$ durante todo o dia, com mínima de $71 \%$, às $13: 00 \mathrm{~h}$. Às 15:00h ocorreu forte precipitação, que persistiu até às 16:30h, totalizando 18,8mm em 2 horas.

A radiação solar global foi reduzida, com muitas variações ao longo do dia, indicando forte nebulosidade. O valor máximo registrado foi de $585,4 \mathrm{~W} / \mathrm{m}^{2}$, às $11: 00 \mathrm{~h}$, com média diária de 139,6 W/m², proveniente de radiação solar difusa, ao longo de 13 horas de insolação. A pressão atmosférica variou $4 \mathrm{mb}$, com pico de $931 \mathrm{mb}$, entre 10:00h e 14:00h, e mínima de $928 \mathrm{mb}$, a partir das 16:30h, permanecendo estável até às $20: 30 h$.

Os ventos predominantes foram do quadrante W/NW, fato que sugeriu tratar-se de uma frente estacionária. Durante a madrugada houve o predomínio de brisa amena do quadrante NE, entretanto, pela manhã os ventos sopraram predominantemente do quadrante NW, sob a forma de brisa leve com rajadas até $2,8 \mathrm{~m} / \mathrm{s}$. No período vespertino, predominaram os ventos do quadrante $\mathrm{W}$, com brisa fraca, cujas rajadas não ultrapassaram $3,4 \mathrm{~m} / \mathrm{s}$ nos momentos que precederam à precipitação.

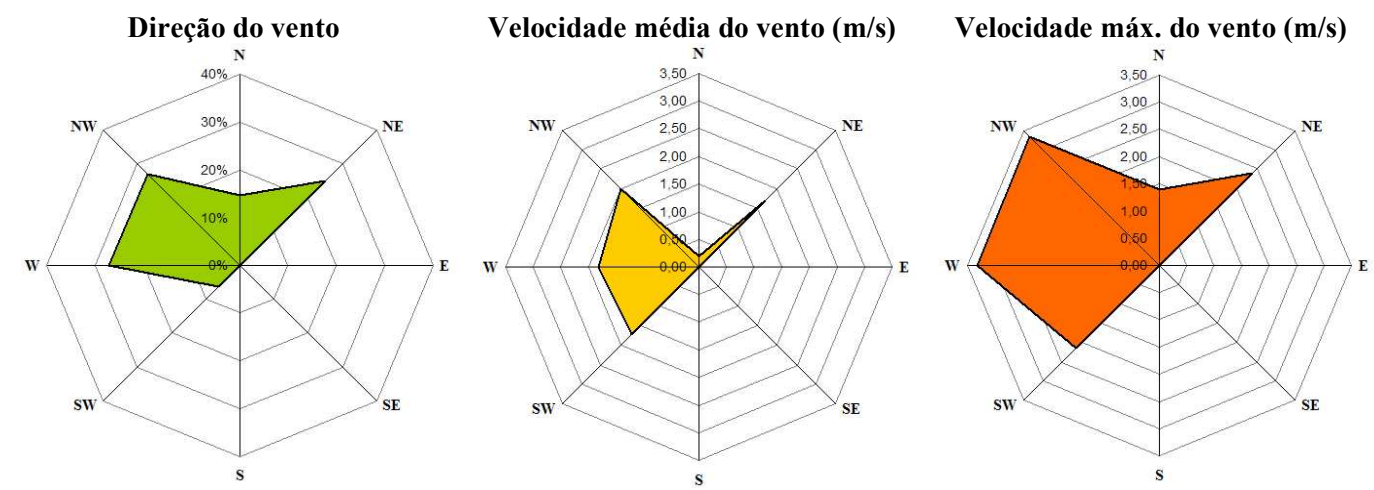

Figura 32: Rosa dos ventos com a dinâmica da circulação do ar no dia 26/02/2005, obtidos por meio de registros de direção e velocidade dos ventos tomados por média a cada 30 minutos pela estação automática localizada no Campus I. 
Observou-se, assim, que o cenário atmosférico apresentou-se instável, com forte nebulosidade ao longo de todo o dia e ocorrência de precipitação à tarde. Os valores da pressão atmosférica apresentaram contínuo declínio em relação ao dia anterior, indicando o domínio da massa Polar Atlântica. As condições sinóticas do dia 26/02/2005 puderam ser atestadas, ainda, pela imagem do canal infravermelho do satélite GOES-12 e pela carta de pressão ao nível do mar (Figura 33).

Nesse dia, o comportamento da temperatura do ar registrada nas quatro estações urbanas apresentou pequenas diferenças entre si, com exceção da estação localizada na Fadisc que apresentou as menores temperaturas durante todo o dia.

Durante a madrugada, o comportamento da temperatura do ar entre as estações foi bastante homogêneo, permanecendo praticamente estável até o nascer do Sol, devido à ocorrência de precipitação e as fortes rajadas de vento no quadrante SE durante as primeiras horas do dia. A estação na Fadisc se destacou por apresentar os menores valores de temperaturas do ar, alcançando a mínima de $18,5^{\circ} \mathrm{C}$, às $4: 30 \mathrm{~h}$.

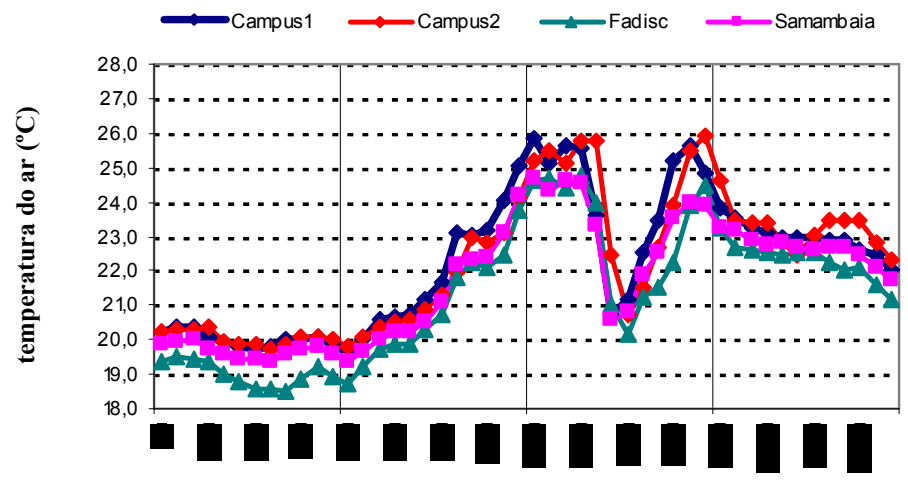

hora do dia (h)

Gráfico 21: Comportamento da temperatura do ar registrada no dia 26/02/2005 nas quatro estações urbanas.

O aquecimento matinal ocorreu de forma gradual e contínua em todas as estações, seguindo a tendência observada no dia anterior, mesmo nas estações no Campus I e no Campus II que apresentaram aquecimento acentuado no início da manhã nas fases de tropicalização e domínio da massa Tropical Atlântica. O aquecimento mais lento na fase de domínio da massa Polar Atlântica justificou-se, principalmente, pela forte nebulosidade que reduziu a incidência de radiação solar direta sobre as superfícies urbanas. As maiores temperaturas diárias ocorreram no início da manhã, apresentando pouca diferença térmica entre as estações analisadas. 
(a)

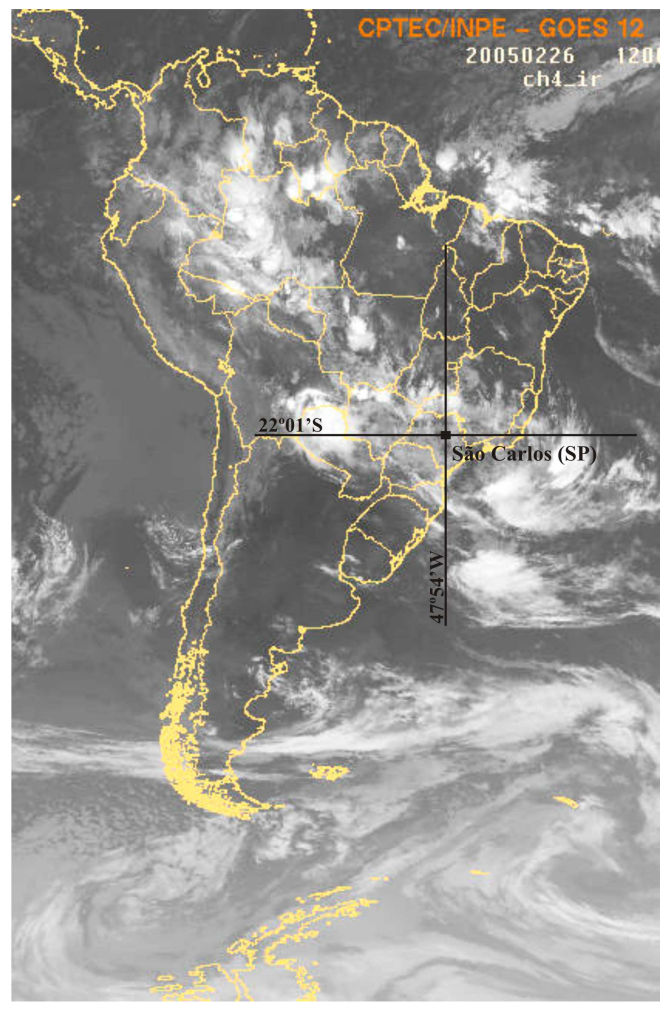

(b)

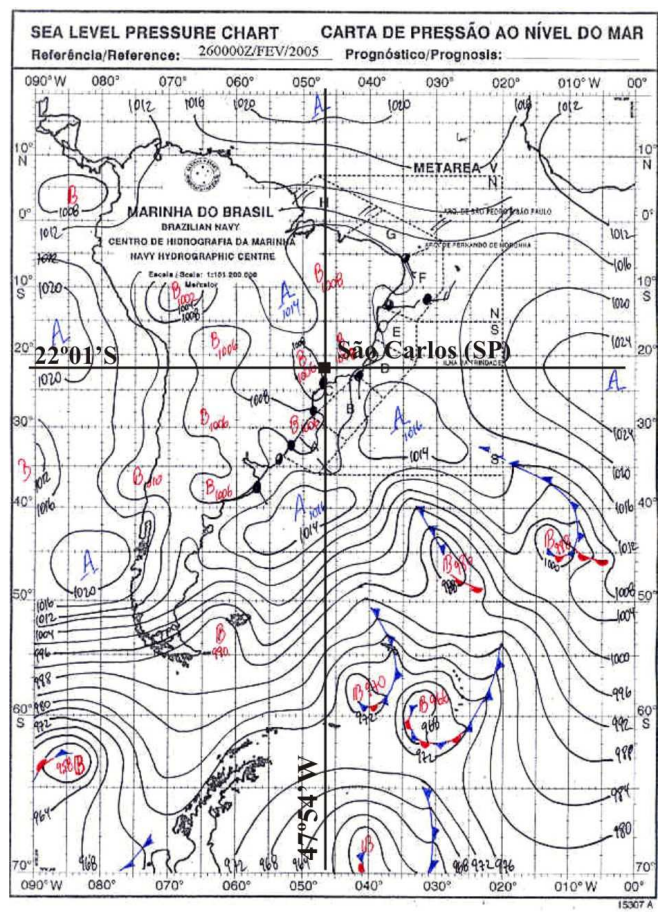

(c)

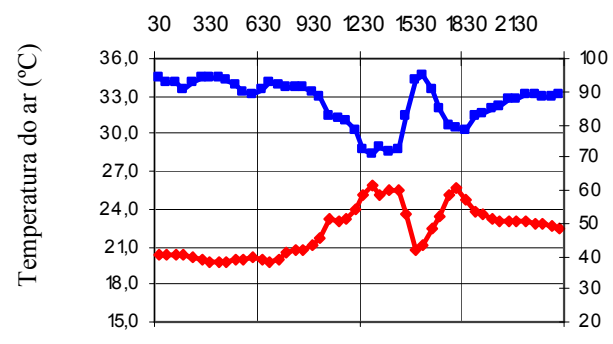

0
0
0
0
0
$\frac{0}{0}$
0
0
0
5
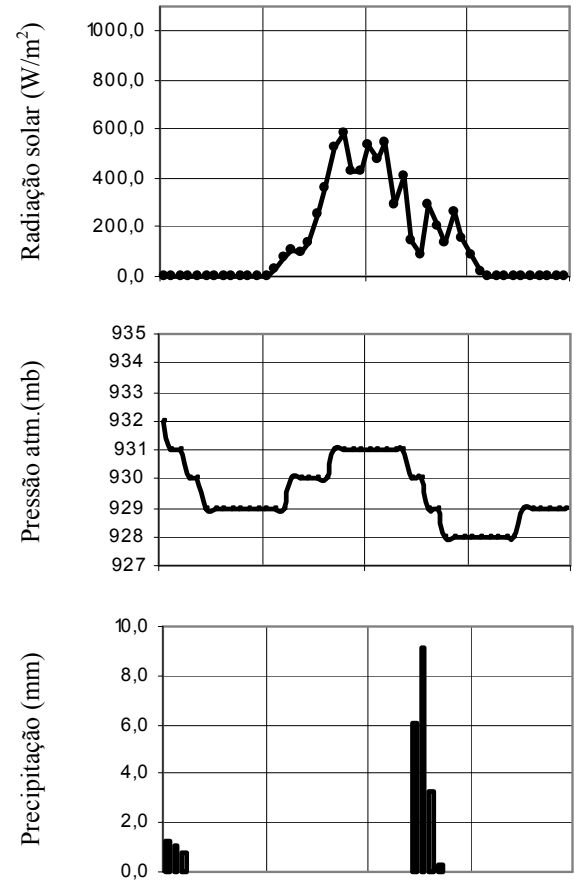

Direção do ar $\nearrow \nearrow \nwarrow \nwarrow \leftarrow \swarrow \leftarrow \uparrow$

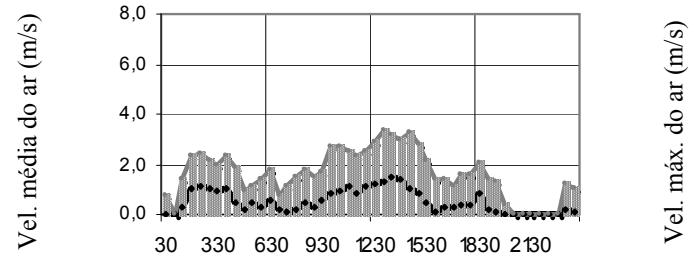

Legenda:

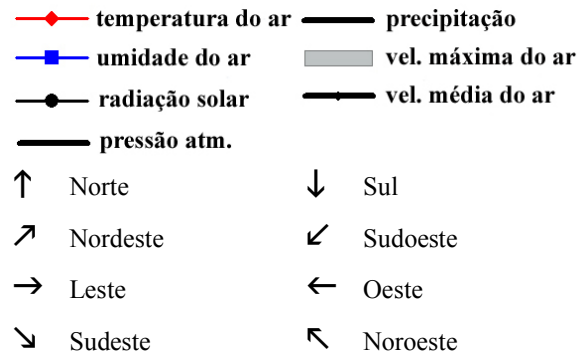

Figura 33: Imagem do satélite GOES-12, canal 4 (infravermelho), e carta de pressão ao nível do mar às 12:00h (horário local) do dia 26/02/2005 e análise rítmica horária com registro dos elementos climáticos tomados a cada 30 minutos. 
A ocorrência de forte precipitação a partir das 15:00h ocasionou queda brusca da temperatura do ar em todas as estações. Após a precipitação, houve significativo incremento nos valores da temperatura do ar, na ordem de $4,9^{\circ} \mathrm{C}$. As estações na Fadisc e no Samambaia apresentam aquecimento menos acentuado que as outras duas estações, possivelmente devido à presença significativa de vegetação arbórea e solo gramado.

Após o pôr-do-sol, as estações apresentaram contínua e gradual redução nos valores de temperatura do ar, apresentando comportamento análogo. A amplitude térmica diária foi em torno de $6,2^{\circ} \mathrm{C}$ em todas as estações, com exceção da estação na Fadisc, que apresentou amplitude térmica de $5,3^{\circ} \mathrm{C}$.

O Gráfico 22 apresenta as diferenças de temperatura do ar observada entre as estações automáticas, duas a duas, ao longo o dia 21/02/2005. A partir da análise dos gráficos observou que as estações seguiram a tendência do dia anterior, apresentando pequenas diferenças térmicas antes do nascer do Sol, favorecida pela forte nebulosidade e pela ocorrência de precipitação na noite anterior e no início da madrugada. A diferença térmica máxima registrada nesses horários foi de $1,5^{\circ} \mathrm{C}$, às 4:30h, entre as estações no Campus I e na Fadisc.

a)

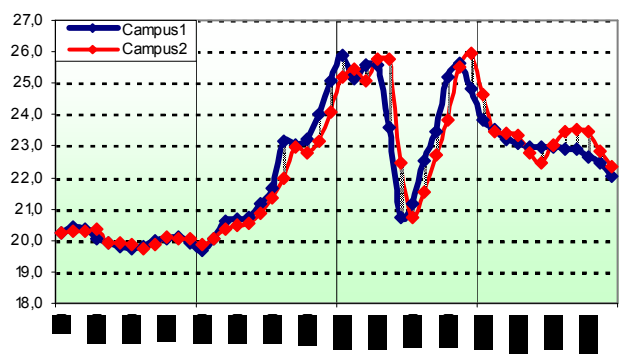

c)

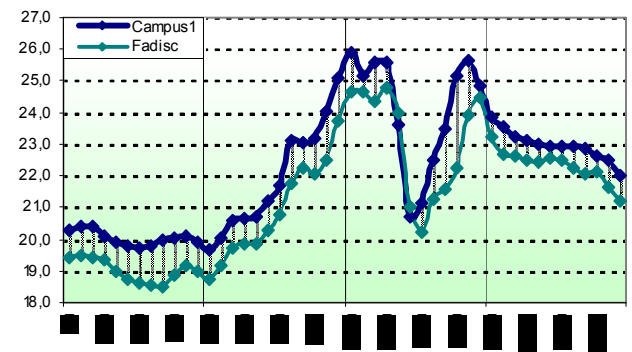

e)

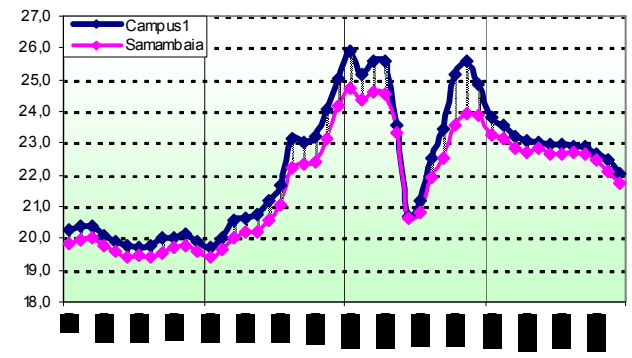

b)

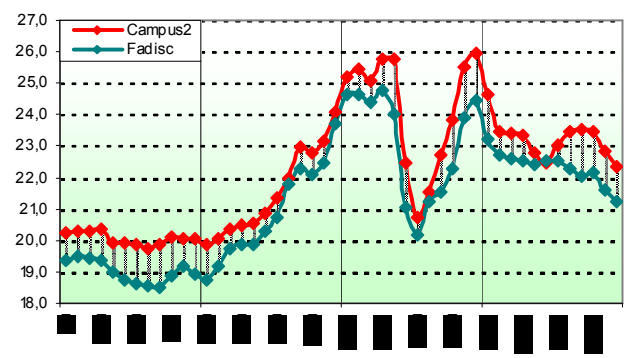

d)

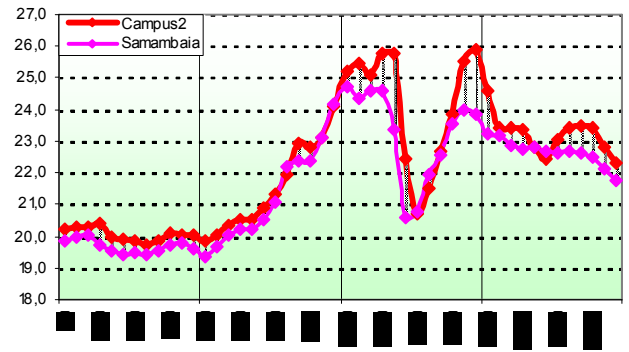

f)

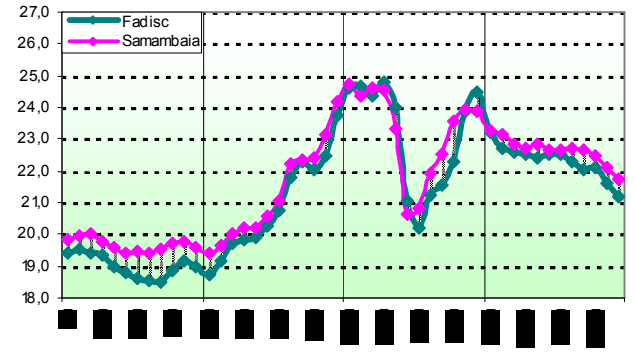

Gráfico 22: Diferenças no comportamento da temperatura do ar registrada no dia 26/02/2005 nas quatro estações urbanas, analisadas duas a duas. 
As estações apresentaram tendência de comportamento térmico semelhantes após o nascer do Sol, apresentando diferenças térmicas inferiores a $2,4^{\circ} \mathrm{C}$ (diferenças térmica registrada entre a estação no Campus II e na Samambaia, às 12:00h). Entretanto, as diferenças de temperatura do ar entre as estações tenderam a se anularem com a ocorrência de forte precipitação às 15:00h voltando a apresentar diferenças térmicas semelhantes, embora com pequeno aumento na intensidade em valores absolutos, após a chuva (ver Gráfico 22).

Dessa forma, as maiores diferenças registradas nesse dia ocorreram após a precipitação. A diferença máxima ocorreu entre as estações no campus I e na Fadisc, na ordem de $2,9^{\circ} \mathrm{C}$. Entre as demais estações, as diferenças térmicas foram menores: na ordem de $2,0^{\circ} \mathrm{C}$, entre as estações no Campus II e no Samambaia; na ordem de $1,6^{\circ} \mathrm{C}$, entre as estações no Campus II e na Fadisc e entre as estações no campus I e no Samambaia; e na ordem de $1,3^{\circ} \mathrm{C}$, entre as estações no Campus I e no Campus II e entre as estações na Fadisc e no Samambaia.

A leitura horizontal da matriz de análise (Gráfico 23) permitiu observar o desempenho térmico nas quatro estações urbanas. Nesse dia, notou-se menor variação no comportamento da diferença térmica entre as estações analisadas em relação ao dia anterior. A leitura horizontal dos gráficos do Campus I mostrou que essa estação voltou apresentar temperaturas mais elevadas em relação às demais, apesar da pouca diferença térmica devido à nebulosidade. Entretanto, esse comportamento foi semelhante ao observado na fase de tropicalização, nos dias 20 e 21/02/2005, fato que sugeriu a existência de uma seqüência na variação do comportamento entre as estações de acordo com o encadeamento dos estados atmosféricos, expresso pelo comportamento do campo térmico urbano de São Carlos.

Os picos de diferenças térmicas observados tiveram relação com a ocorrência de forte precipitação, às 17:00h, apresentando variação na resposta térmica observada em cada estação. Nesse sentido, observou-se que a estação na Fadisc respondeu rapidamente por meio da redução da temperatura do ar, enquanto a resposta da estação no Campus I foi mais lenta, mantendo-se mais aquecida em relação às demais, apesar da precipitação.

Com exceção do momento de ocorrência de precipitação, as diferenças térmicas observadas entre as estações apresentam pouca variação, mantendo padrão quase constante, expresso pela distância contínua dos pontos projetados em relação ao eixo das abcissas. 


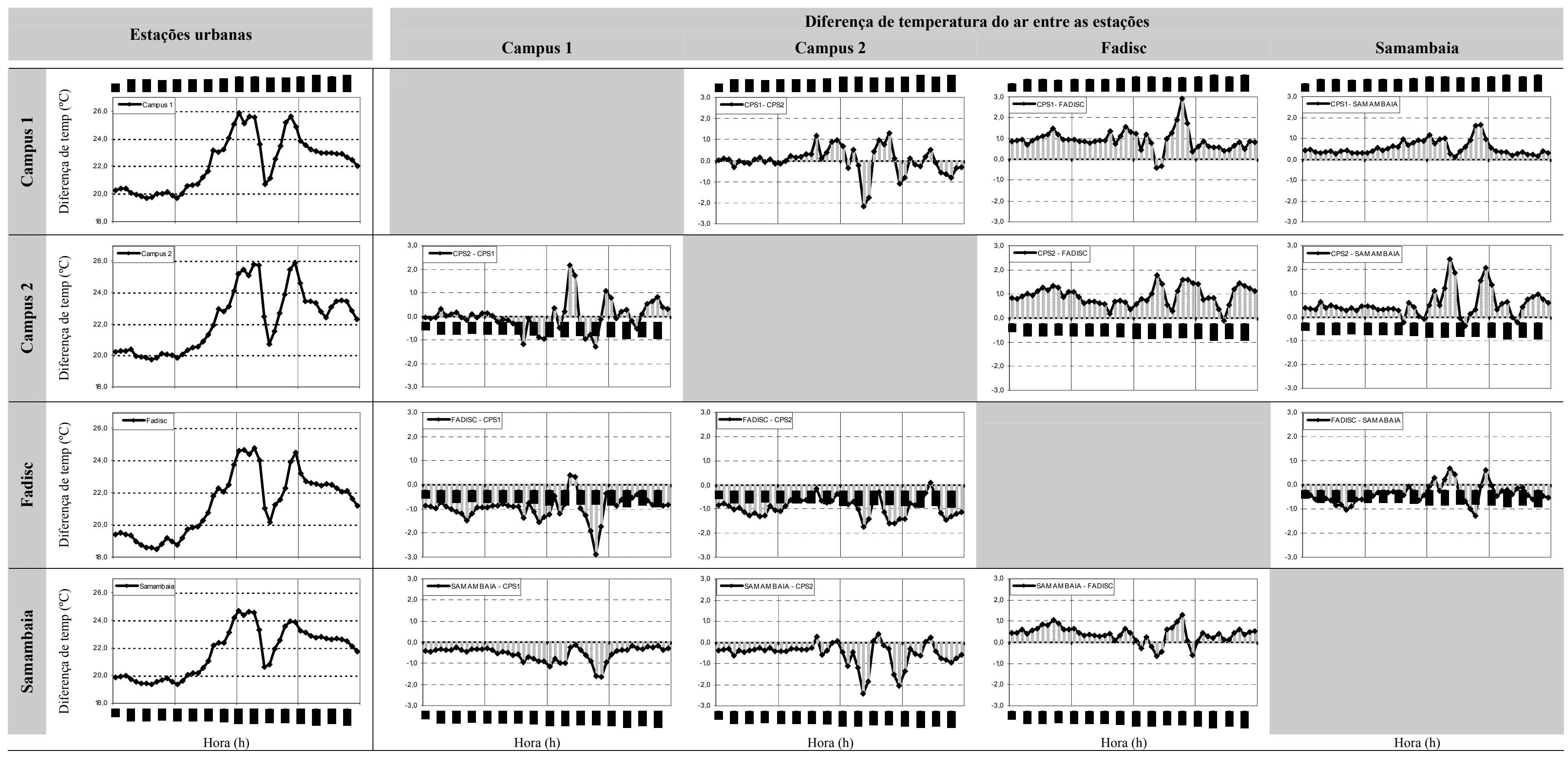

Gráfico 23: Matriz de análise do comportamento térmico das quatro estações automáticas no dia 26/02/2005. A leitura horizontal dos gráficos permite acompanhar o comportamento diário de cada estação em relação às demais, indicando maior ou menor aquecimento do ar de acordo com a projeção acima ou abaixo do eixo das coordenadas, respectivamente, enquanto a leitura vertical dos gráficos permite a análise das estaçôes automáticas tomadas a partir de uma estação de referência, indicada acima de cada coluna. 


\section{- Dia 27 de fevereiro de 2005}

O dia 27/02/2005 permaneceu sob forte nebulosidade, condição característica da fase de domínio da massa Polar Atlântica sobre o local. O céu encoberto favoreceu a reduzida amplitude térmica diária, mantendo a tendência do dia precedente, na ordem de $6,5^{\circ} \mathrm{C}$. Os valores registrados de temperatura máxima e mínima também seguiram a tendência do dia anterior, com valores de $27,2^{\circ} \mathrm{C}$, às $16: 30 \mathrm{~h}$, e $20,7^{\circ} \mathrm{C}$, a partir das 23:30h, continuando em decréscimo até o nascer do Sol.

Os índices de umidade relativa do ar continuaram elevados durante todo o dia, próximo aos $70 \%$. A mínima ocorreu às $17: 00$ h (64\%), próximo ao horário de maior aquecimento do ar. O elevado volume de vapor d'água disponível na atmosfera favoreceu a ocorrência de chuvas. No início da tarde ocorreu fraca precipitação $(0,75 \mathrm{~mm})$, voltando a chover mais intensamente às $17: 30 \mathrm{~h}$, persistindo até às $21: 00 \mathrm{~h}$, totalizando $14,7 \mathrm{~mm}$.

A radiação solar global foi um pouco mais elevada do que o dia anterior, indicando que a forte nebulosidade do dia precedente já se encontrava em processo de dissipação, embora o céu continua-se encoberto. O valor máximo registrado foi de $671,8 \mathrm{~W} / \mathrm{m}^{2}$, às $13: 30 \mathrm{~h}$, com média diária de $159,9 \mathrm{~W} / \mathrm{m}^{2}$, proveniente de radiação solar difusa, ao longo de 13 horas de insolação. A pressão atmosférica variou $3 \mathrm{mb}$, com pico de $931 \mathrm{mb}$, a partir das 9:30h, permanecendo estável até às 12:00h; e mínima de 928mb, a partir das 16:00h, permanecendo estável até às 17:30h.

Os ventos predominantes continuaram no quadrante $\mathrm{W}$, fato que sugeriu tratarse de uma frente estacionária sobre a região de São Carlos. Durante a manhã houve ocorrência de brisas leves, com velocidades inferiores a 3,2m/s. No período vespertino sopraram brisas fracas, com rajadas de até $4,1 \mathrm{~m} / \mathrm{s}$, com variações entre os quadrantes W e NW, voltando a soprar brisas leves durante a noite.
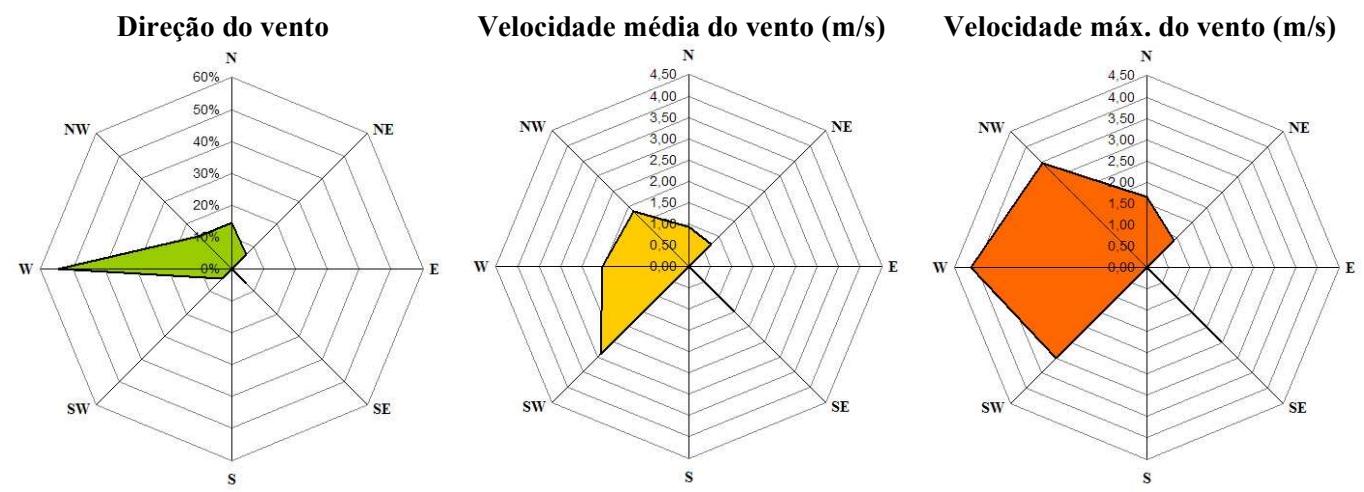

Figura 34: Rosa dos ventos com a dinâmica da circulação do ar no dia 27/02/2005, obtidos por meio de registros de direção e velocidade dos ventos tomados por média a cada 30 minutos pela estação automática localizada no Campus I. 
Neste sentido, observou-se que o cenário atmosférico permaneceu semelhante às condições de tipo de tempo ocorridas no dia precedente, indicando a continuidade do domínio da massa Polar Atlântica sobre a região de São Carlos na forma de frente estacionária, indicada pela predominância dos ventos do quadrante W. A imagem do canal infravermelho do satélite GOES-12 atestou a forte nebulosidade sobre a região de São Carlos, porém em processo de dissipação (Figura 35).

Nesse dia, o comportamento da temperatura do ar registrada nas quatro estações urbanas foi semelhante, porém com diferenças nos valores registrados durante todo o dia. A estação na Fadisc continuou apresentar as menores temperaturas diárias, chegando a apresentar diferenças térmicas significativas com relação às demais estações, no período vespertino e noturno.

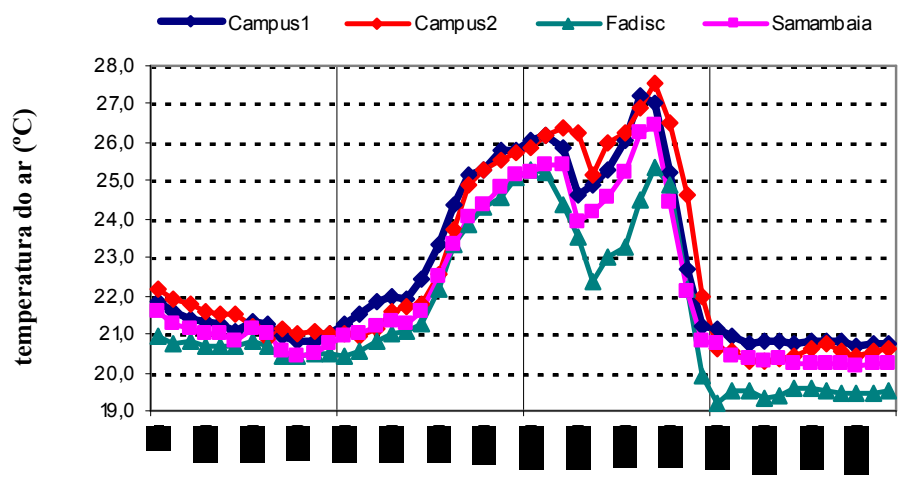

hora do dia (h)

Gráfico 24: Comportamento da temperatura do ar registrada no dia 27/02/2005 nas quatro estações urbanas.

Durante a madrugada, o comportamento da temperatura do ar entre as estações foi bastante homogêneo, voltando a apresentar tendência de decréscimo nos valores da temperatura apesar da nebulosidade, com mínima registrada ao nascer do Sol. Nesse sentido, observou-se diferença nos valores registrados nesses horários, indicando o comportamento diferenciado na troca de radiação calorífica para a abóbada celeste por processo convectivo.

No início da manhã, o aquecimento ocorreu de forma lenta em todas as estações devido à forte nebulosidade sobre a região, característica da fase de domínio da Polar Atlântica. Entretanto, a partir da 10:00h, a maior dissipação das nuvens permitiu maior aquecimento das superfícies urbanas. As estações no Campus I e no Campus II apresentaram maior aquecimento que as outras duas estações. A leve precipitação no início da tarde promoveu a queda de temperatura em todas as estações, entretanto, a estação na Fadisc apresentou queda acentuada, alcançando $22,4^{\circ} \mathrm{C}$. 
(a)

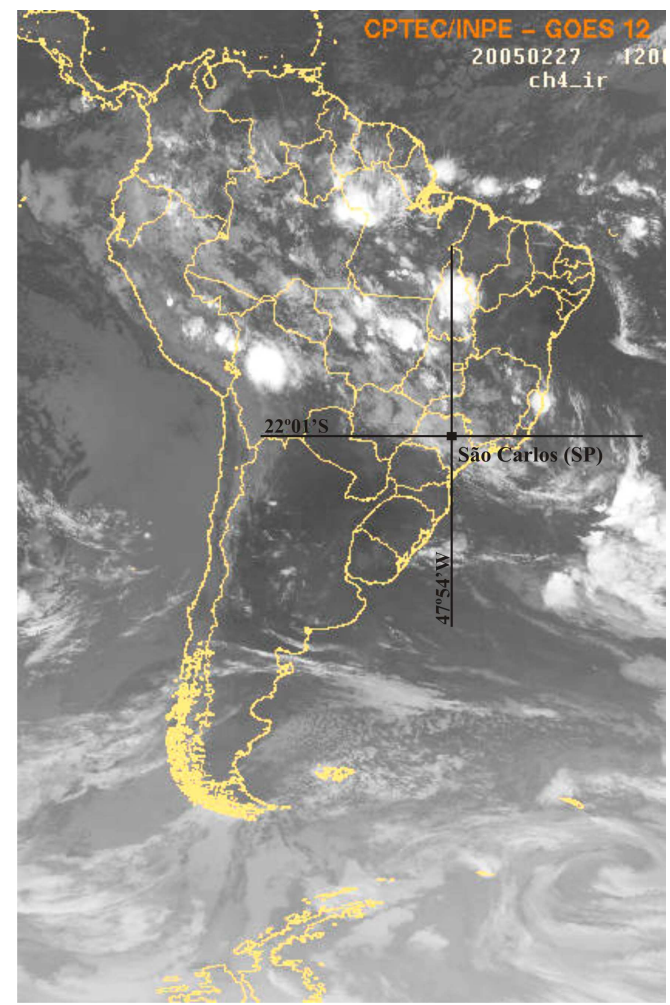

(b)

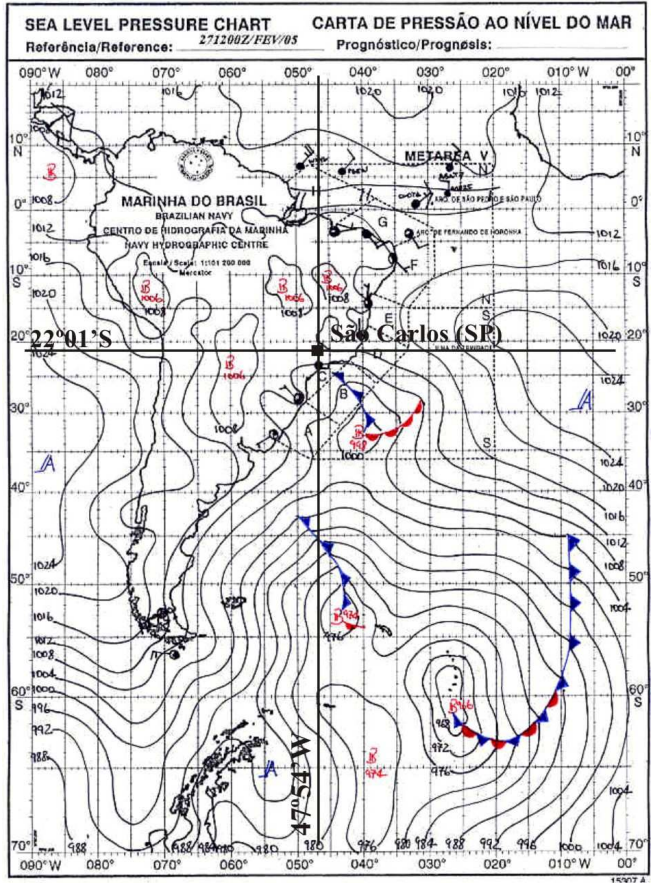

(c)
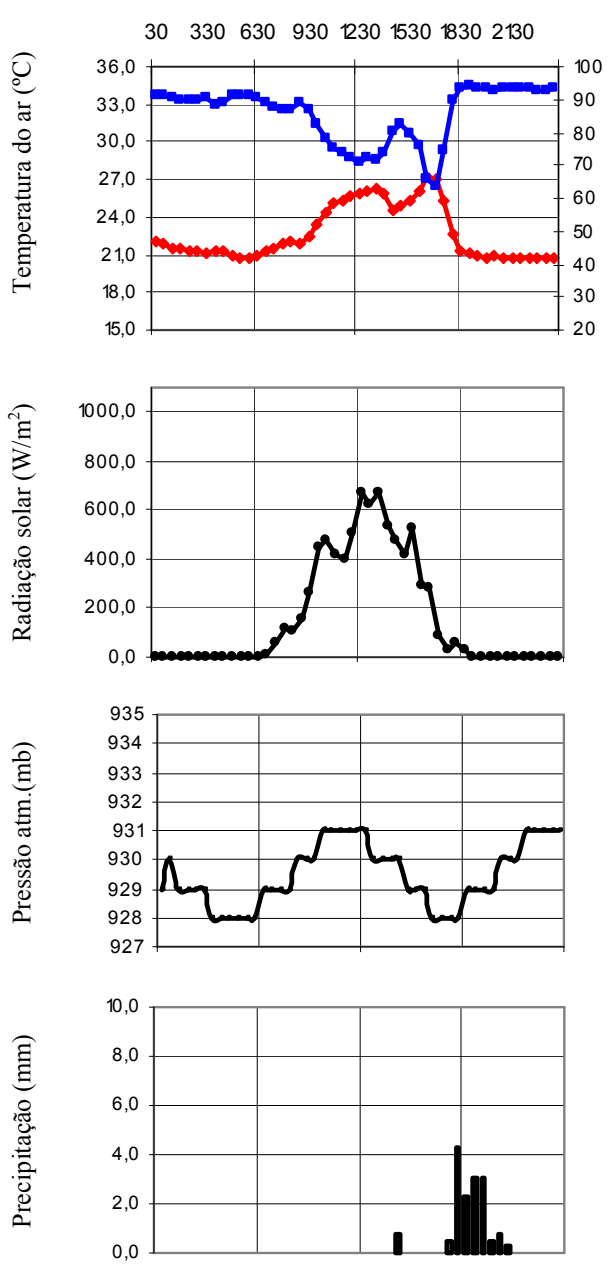

Direção do ar $\uparrow \leftarrow \leftarrow \leftarrow \leftarrow \leftarrow \leftarrow \leftarrow$

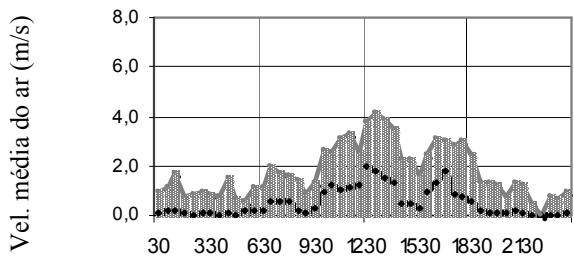

Legenda:

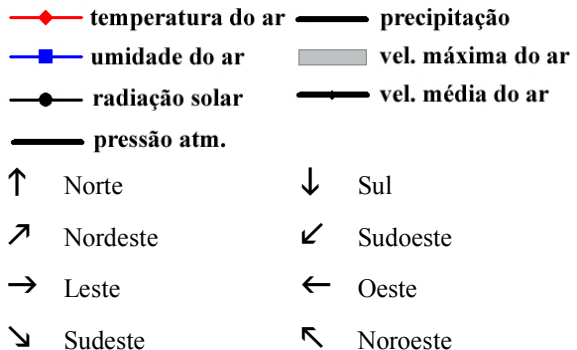

Figura 35: Imagem do satélite GOES 12, canal 4 (infravermelho), e carta de pressão ao nível do mar às 9:00h (horário local) do dia 27/02/2005 e análise rítmica horária com registro dos elementos climáticos tomados a cada 30 minutos. 
As maiores temperaturas foram registradas às $16: 30 \mathrm{~h}$, pouco antes da ocorrência de forte precipitação que reduziu consideravelmente a temperatura em todas as estações. As estações no Campus I e no Campus II apresentaram as maiores temperaturas $-27,2^{\circ} \mathrm{C}$ e $27,5^{\circ} \mathrm{C}$, respectivamente. Com a ocorrência da precipitação, que teve início às $17: 30 \mathrm{~h}$, registrou-se nova queda nos valores da temperatura do ar. No início da noite, todas as estações apresentaram temperatura do ar próxima aos $21,5^{\circ} \mathrm{C}$, com exceção da estação da estação na Fadisc, que apresentou registro de $19,5^{\circ} \mathrm{C}$. A amplitude térmica diária foi semelhante em todas as estações analisadas, próxima aos $6,5^{\circ} \mathrm{C}$.

O Gráfico 25 apresenta as diferenças de temperatura do ar observada entre as estações automáticas, duas a duas, ao longo o dia 27/02/2005. A partir da análise dos gráficos observou que durante a madrugada as estações apresentaram comportamento análogo com pouca diferença térmica entre si.

a)

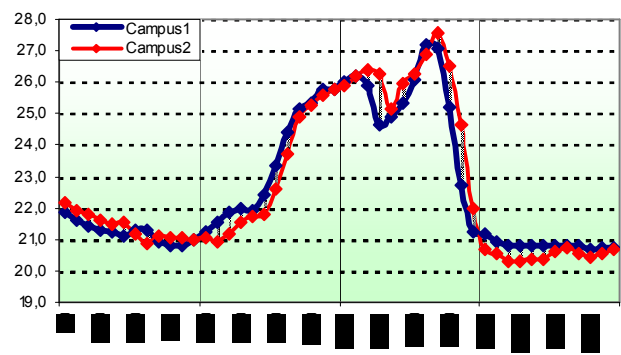

c)

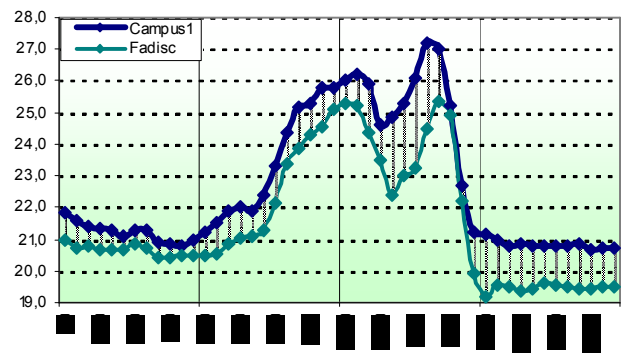

e)

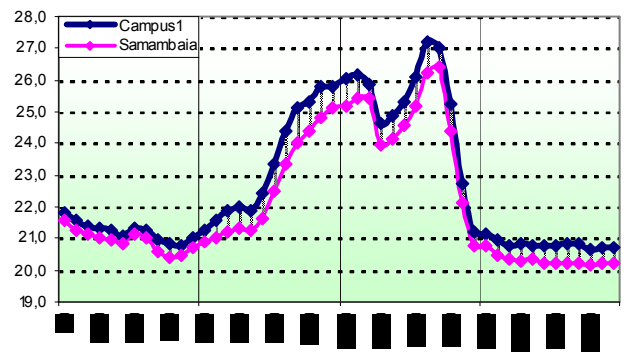

b)

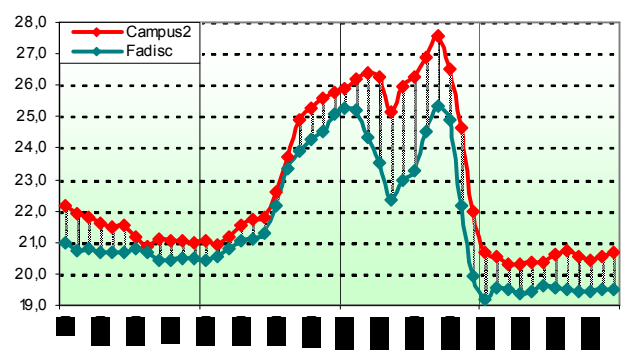

d)

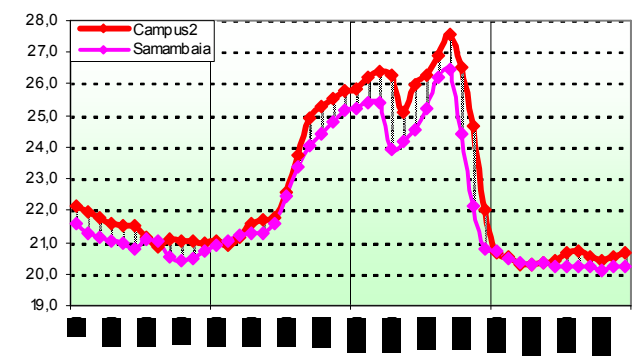

f)

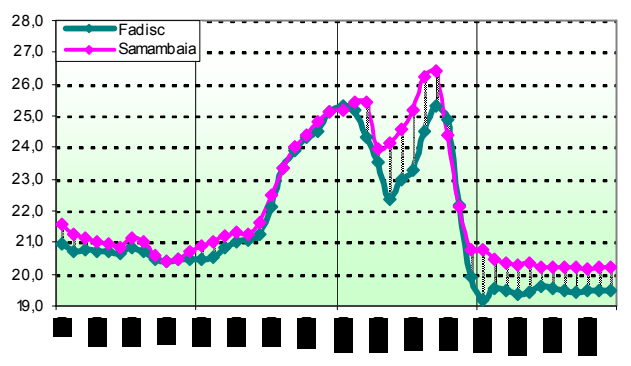

Gráfico 25: Diferenças no comportamento da temperatura do ar registrada no dia 27/02/2005 nas quatro estações urbanas, analisadas duas a duas. 


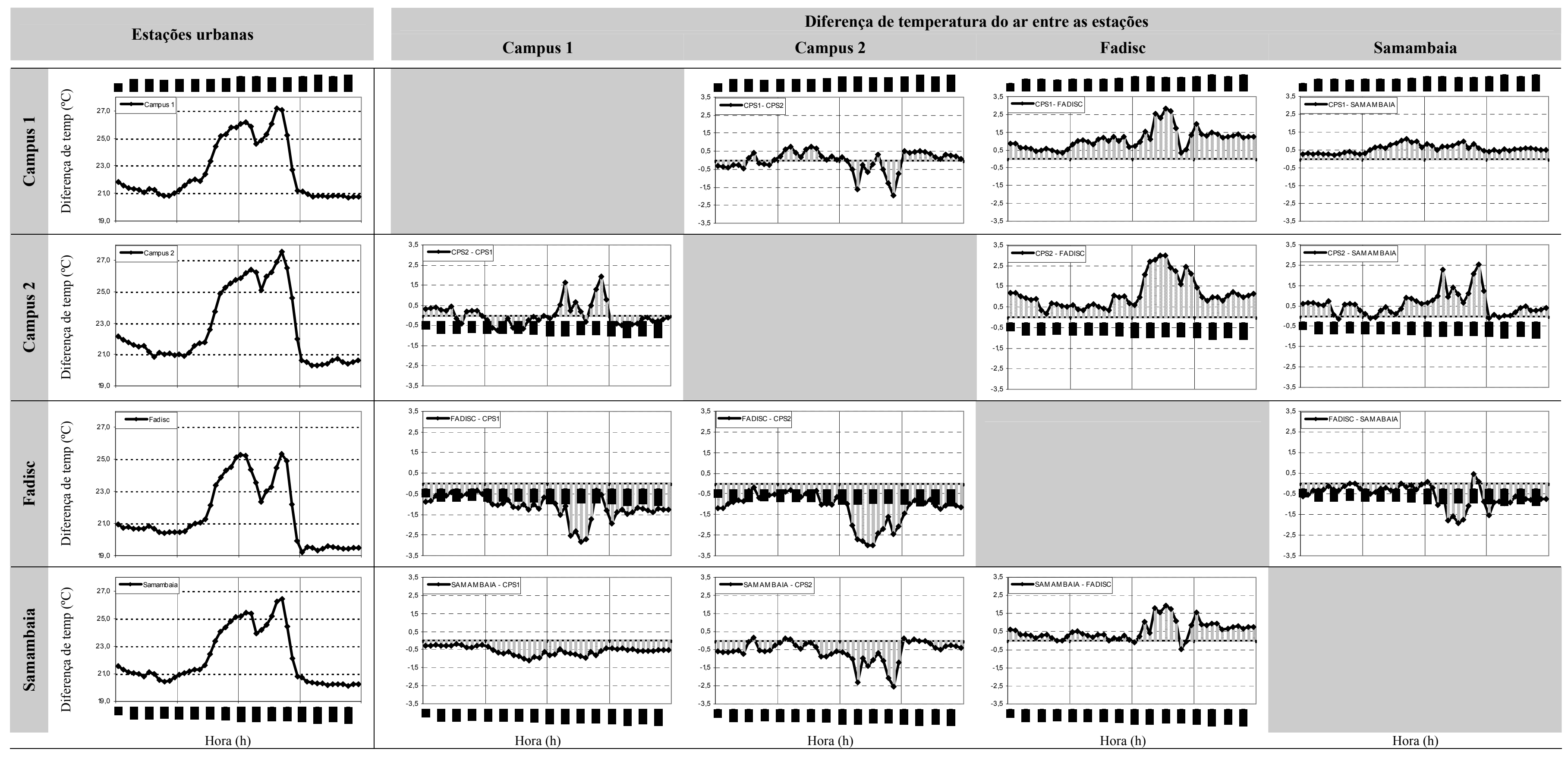

Gráfico 26: Matriz de análise do comportamento térmico das quatro estações automáticas no dia 27/02/2005. A leitura horizontal dos gráficos permite acompanhar o comportamento diário de cada estação em relação às demais,

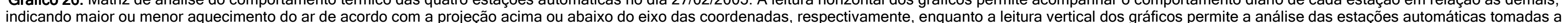
partir de uma estação de referência, indicada acima de cada coluna. 
As maiores diferenças de temperatura do ar foram observadas no período vespertino, próximo a ocorrência de franca precipitação às 14:30h. Nesse sentido, foi registrada diferença térmica entre as estações no Campus II e na Fadisc na ordem de $3,0^{\circ} \mathrm{C}$, às $15: 00 \mathrm{~h}$. No mesmo horário, registrou-se diferença de $2,8^{\circ} \mathrm{C}$ entre as estações no Campus I e na Fadisc e diferença de $1,9^{\circ} \mathrm{C}$ entre as estações na Fadisc e no Samambaia. Essas diferenças foram devido ao rápido resfriamento observado na estação na Fadisc com a ocorrência de precipitação.

A estação na Fadisc permaneceu com temperaturas menos elevadas após a precipitação no final da tarde, o que resultou no registro de diferenças térmicas entre essa estação e às demais no período noturno, na ordem de $2,0^{\circ} \mathrm{C}$, em relação à estação no Campus I, às $18: 30 \mathrm{~h} ; 1,9^{\circ} \mathrm{C}$ em relação à estação no Samambaia, às 18:30h; e $1,2^{\circ} \mathrm{C}$ em relação à estação no Campus II, às 22:00h.

A leitura horizontal da matriz de análise (Gráfico 26) permitiu observar o desempenho térmico das quatro estações urbanas analisadas. Os gráficos do Campus I mostraram que, nessa estação, manteve-se a tendência de maior aquecimento em relação às demais estações no decorrer do dia, com exceção da estação no Campus II, que se apresentou mais aquecida no período vespertino, com picos de diferenças de $1,6^{\circ} \mathrm{C}$, às $14: 00 \mathrm{~h}$, e $1,9^{\circ} \mathrm{C}$, às $17: 30 \mathrm{~h}$.

Observou-se, ainda, que as diferenças apresentadas com relação à estação no Samambaia foram inferiores $1^{\circ} \mathrm{C}$, o que indicou que nesse dia o comportamento entre as duas estações foram semelhantes.

Com relação ao Campus II, a leitura horizontal dos gráficos comprovou a tendência em apresentar comportamento semelhante ao observado na estação no Campus I, com exceção dos momentos que antecederam as precipitações no período vespertino, no quais a estação do Campus II apresentou picos de maior aquecimento do ar. Notou-se, ainda, intensa diferença de temperatura do ar entre essa estação e a estações na Fadisc, sobretudo durante a tarde, quando houve ocorrência de precipitação. A diferença térmica entre essas duas estações permaneceu durante a noite, entretanto com menor intensidade.

\section{FASE DE TROPICALIZAÇÃO}

A partir do dia 28/02/2005 iniciou o processo de tropicalização da massa Polar Atlântica, indicando a transição entre o domínio da Polar Atlântica e o retorno às condições atmosféricas características do domínio da Tropical Atlântica. 


\section{- Dia 28 de fevereiro de 2005}

No dia 28/02/2005 observou-se aumento significativo na amplitude térmica diária, alcançando $9,2^{\circ} \mathrm{C}$. Esse comportamento deve-se, em parte, à contínua dissipação da forte nebulosidade presente nos dois últimos dias devido ao avanço da frente Polar Atlântica sobre a região. O céu menos encoberto permitiu maior aquecimento da superfície por radiação solar direta durante o dia e maior troca de energia por radiação entre a superfície e a abóbada celeste durante à noite. Nesse sentido, a temperatura máxima do ar foi registrada às $15: 30 \mathrm{~h}$, com valor de $28,9^{\circ} \mathrm{C}$, enquanto a temperatura mínima ocorreu pouco após o nascer do Sol, às 7:00h, com valor de $19,7^{\circ} \mathrm{C}$.

Os índices de umidade relativa do ar apresentaram leve queda, conseqüência do aumento da média diária da temperatura do ar, entretanto não implicou necessariamente na redução da quantidade de vapor d'água disponível na atmosfera, visto que o índice mínimo diário registrado foi de $58 \%$, às $16: 00 \mathrm{~h}$, próximo ao horário de maior temperatura do ar diária. No final da tarde ocorreu fraca precipitação, com totais pluviométricos de $0,76 \mathrm{~mm}$.

Os valores de radiação solar global permaneceram em elevação devido à contínua dissipação da nebulosidade. O valor máximo registrado foi de $755 \mathrm{~W} / \mathrm{m}^{2}$, às 13:30h, com média diária de $188,8 \mathrm{~W} / \mathrm{m}^{2}$, ao longo de 13 horas de insolação. O gráfico dos valores horários apresenta menor variação com relação aos dias precedentes, apresentando pequena tendência em assumir a forma de parabólica característica de céu claro.

A pressão atmosférica variou $4 \mathrm{mb}$, com pico de $933 \mathrm{mb}$, a partir das 9:30h, permanecendo estável até às 13:00h; e mínima de 929mb, entre 18:30h e 19:00h. A tendência de elevação da pressão atmosférica em relação aos dois dias precedentes foi indício do início de tropicalização da massa Polar Atlântica que dominou as condições atmosféricas na região.

Os ventos predominantes foram dos quadrantes NE e W. A ocorrência significativa dos ventos do quadrante NE corroborou como indício de tropicalização da massa Polar Atlântica e o retorno gradativo do domínio do cenário atmosférico pela massa Tropical Atlântica sobre a região. Durante a madrugada houve a predominância de aragem do quadrante NE. Pela manhã, os ventos adquiriram maior intensidade ganhando característica de brisas leve. À tarde, ocorreu inversão na direção dos ventos dominantes que passaram a soprar do quadrante $W$ com rajadas até $3,3 \mathrm{~m} / \mathrm{s}$, retornando ao quadrante $\mathrm{N}$ após o pôr-do-sol, com períodos de calmaria. 

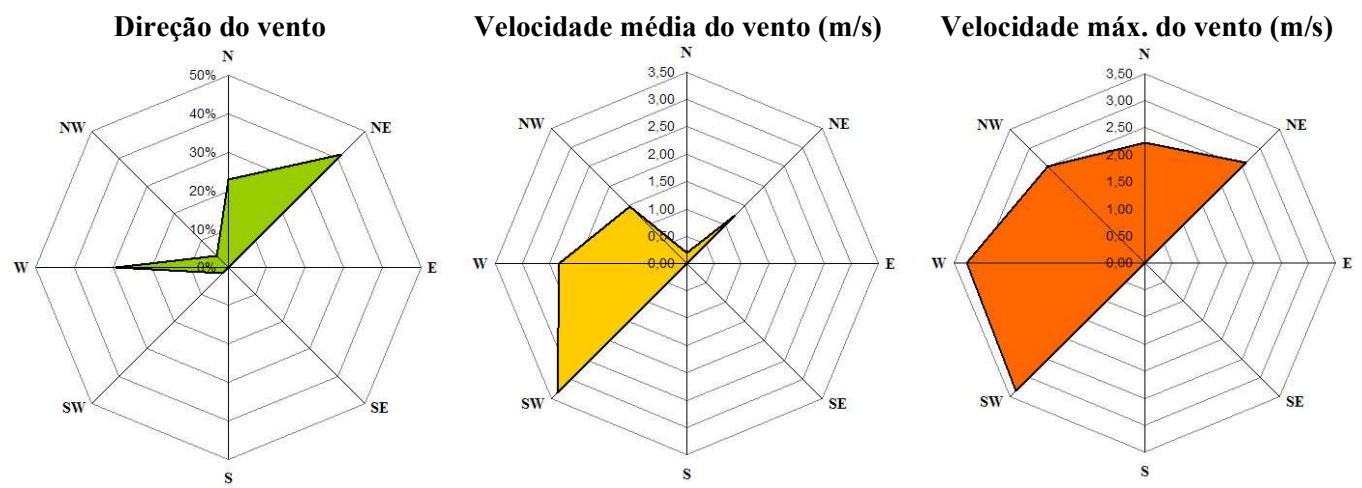

Figura 36: Rosa dos ventos com a dinâmica da circulação do ar no dia 28/02/2005, obtidos por meio de registros de direção e velocidade dos ventos tomados por média a cada 30 minutos pela estação automática localizada no Campus I.

Neste sentido, observou-se que o cenário atmosférico começou a se modificar entrando em fase de transição entre os tipos de tempo característicos do domínio da massa Polar Atlântica e da massa Tropical Atlântica.

A imagem do canal infravermelho do satélite GOES-12 atestou o princípio de dissipação da forte nebulosidade que dominou sobre a região de São Carlos ao longo dos dois dias precedentes. Observou-se, assim, o início do processo de tropicalização da massa Polar Atlântica que dominou as condições do tipo de tempo desde o avanço do sistema frontal no dia 25/02/2005.

Nesse dia, o comportamento da temperatura do ar registrada nas quatro estações urbanas foi semelhante ente si, conforme mostra o Gráfico 27, apresentando reduzidas diferenças de temperaturas do ar devido à presença de nebulosidade e a elevada disponibilidade de vapor d'água na atmosfera.

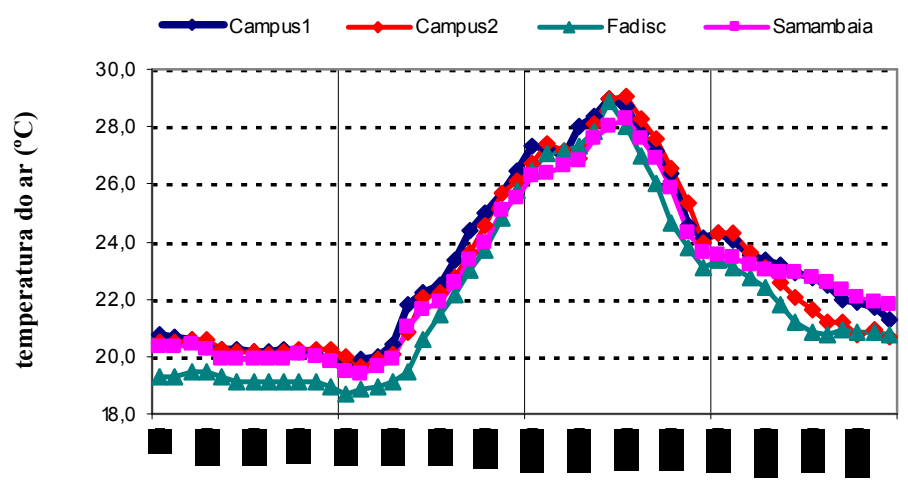

hora do dia (h)

Gráfico 27: Comportamento da temperatura do ar registrada no dia 28/02/2005 nas quatro estações urbanas. 
(a)

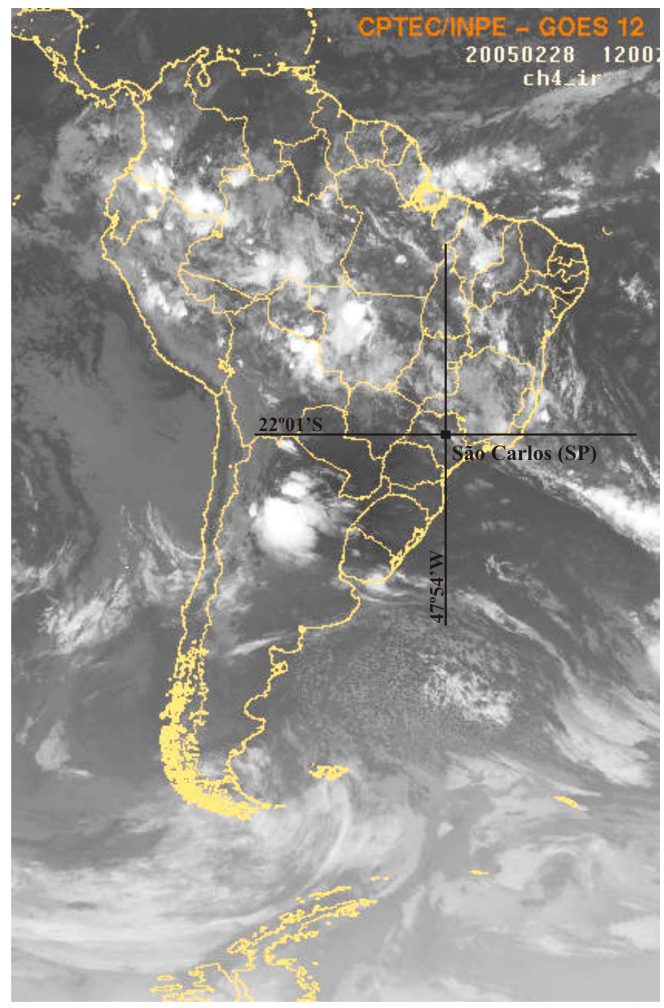

(b)

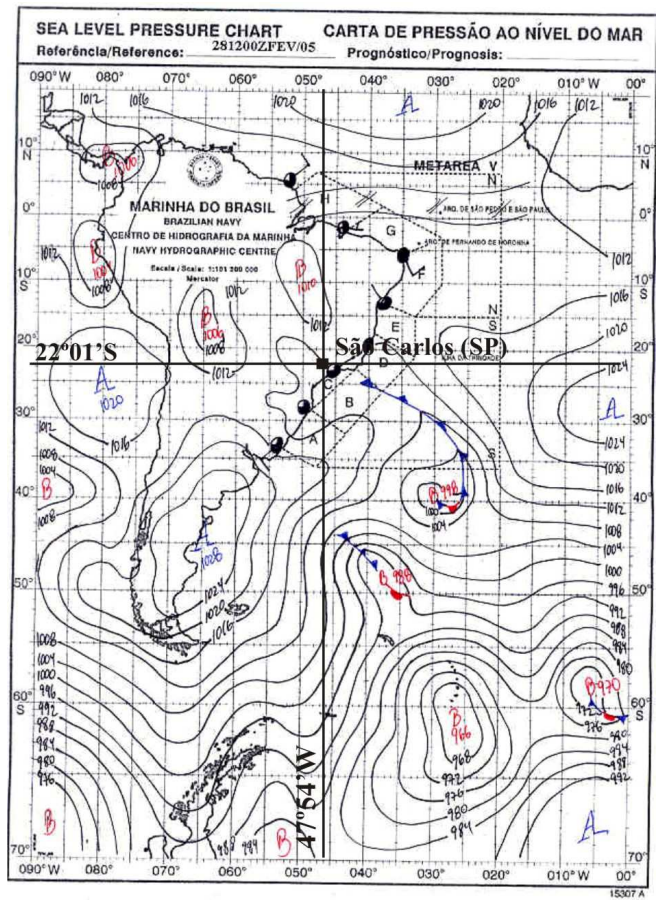

(c)

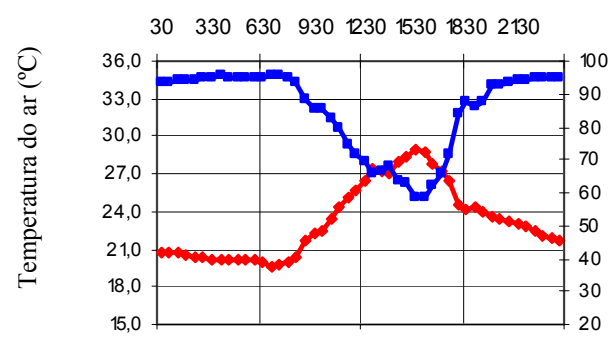

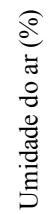
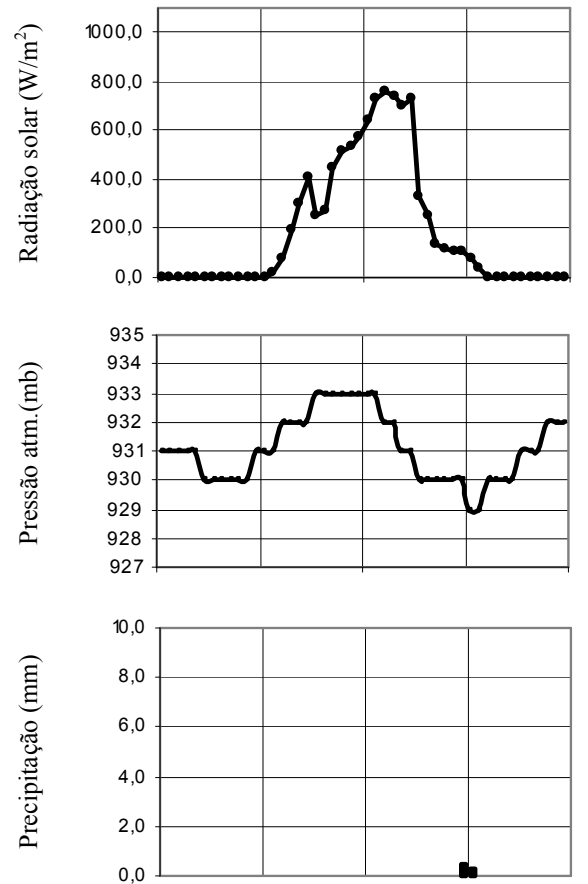

Direção do ar $\nearrow \nearrow \nearrow \nearrow \nearrow \leftarrow \uparrow$

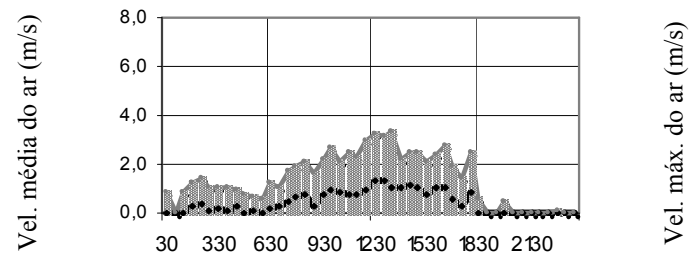

Legenda:

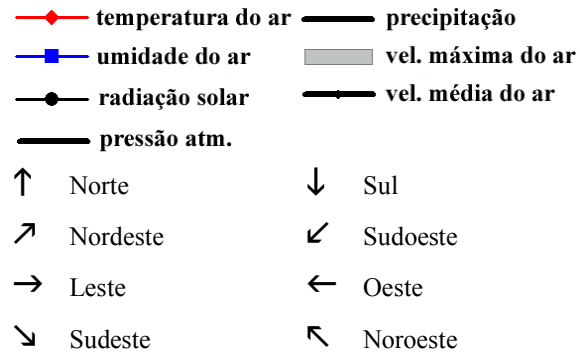

Figura 37: Imagem do satélite GOES-12, canal 4 (infravermelho), e carta de pressão ao nível do mar às 9:00h (horário local) do dia 28/02/2005 e análise rítmica horária com registro dos elementos climáticos tomados a cada 30 minutos. 
Durante a madrugada o comportamento da temperatura do ar entre as estações foi bastante homogêneo, mantendo-se praticamente estável em todas as estações, devido à nebulosidade que dificultou a troca de radiação calorífica para a abóbada celeste, apesar da incidência dos ventos do quadrante SE durante toda a madrugada. A estação da Fadisc apresentou menores temperaturas do ar nesse período.

No início da manhã, o aquecimento ocorreu de forma lenta em todas as estações devido à nebulosidade sobre a região. Durante o período matutino e vespertino, as estações apresentaram valores semelhantes de temperatura do ar, o que indicou a conformação de campo térmico homogêneo. As maiores temperaturas foram registradas próxima às 15:00h em todas as estações, alcançando picos próximo a $29^{\circ} \mathrm{C}$. A menor máxima diária foi registrada na estação no Samambaia, $28,3^{\circ} \mathrm{C}$.

Após às 16:00h, houve a incidência de maior nebulosidade sobre a região, possivelmente resultado do maior aquecimento do ar e elevada disponibilidade de vapor d'água na atmosfera, o que provocou o decréscimo nos valores de temperatura do ar registrados em todas as estações. No período noturno, o decréscimo da temperatura do ar continuou acentuado nas estações na Fadisc e no Campus II, enquanto que a redução nos valores de temperatura foi mais amena nas outras duas estações.

O Gráfico 28 apresenta as diferenças de temperatura do ar observada entre as estações automáticas, duas a duas, ao longo o dia 28/02/2005. A partir da análise dos gráficos notou-se que as estações analisadas continuaram apresentando comportamentos semelhantes ao longo do dia. Durante a madrugada, as diferenças de temperatura do ar observadas foram inferiores a $1,1^{\circ} \mathrm{C}$, registrada entre as estações no Campus I e na Fadisc. Entretanto, as maiores diferenças térmicas nesse dia foram observadas no início da manhã entre as estações no Campus I e na Fadisc, na ordem de $2,3^{\circ} \mathrm{C}$, às $8: 30 \mathrm{~h}$; entre as estações no Campus II e na Fadisc, $1,4^{\circ} \mathrm{C}$, às 9:00h; e entre as estações na Fadisc e no Samambaia, $1,5^{\circ} \mathrm{C}$, às $8: 30 \mathrm{~h}$. Essas diferenças térmicas devem-se ao lento aquecimento do ar notado na estação na Fadisc.

Durante o período vespertino, as quatro estações urbanas tenderam a comportamentos semelhantes, cujas diferenças térmicas entre si foram inferiores a $1,2^{\circ} \mathrm{C}$, registrada entre as estações no Campus I e no Campus II e entre as estações do Campus I e do Samambaia, ambas às 14:00h. No horário de maior aquecimento do ar, às 15:00h, as estações no Campus I, no Campus II e no Samambaia registram o mesmo valor de temperatura do ar, o que indicou homogeneidade no campo térmico urbano. Esse fato deve-se à nebulosidade que ainda predominava sobre a abóbada celeste, embora em processo de dissipação. 
a)

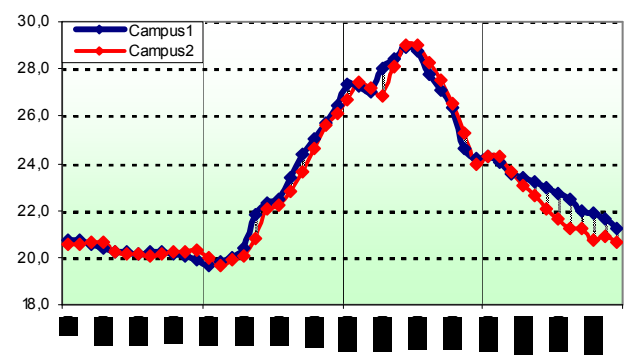

c)

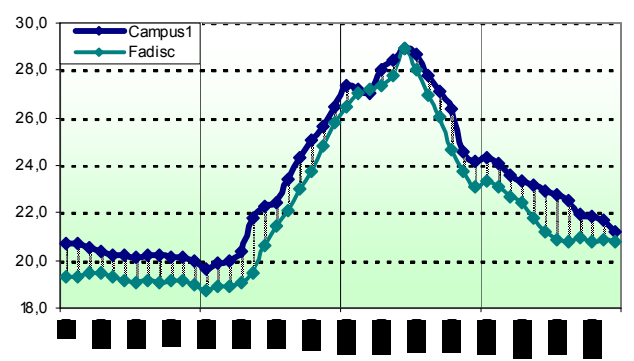

e)

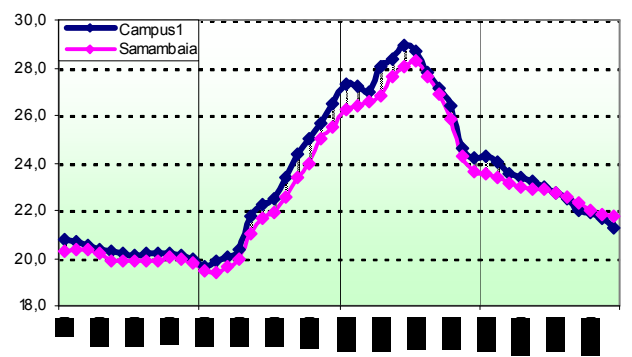

b)

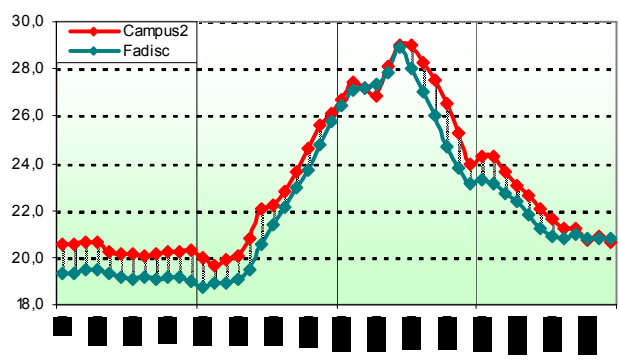

d)

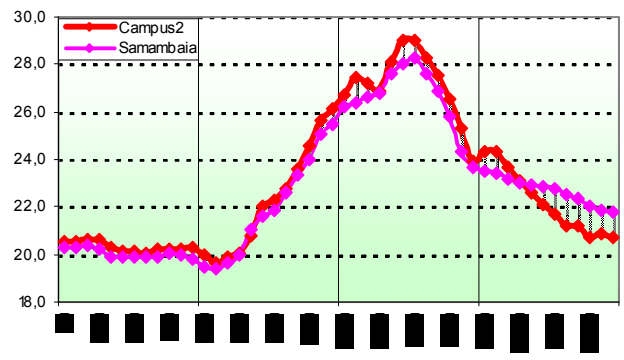

f)

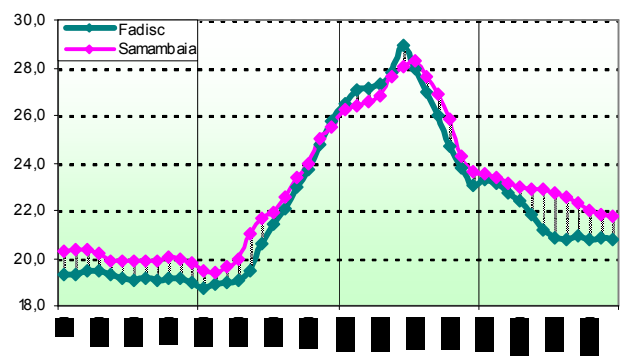

Gráfico 28: Diferenças no comportamento da temperatura do ar registrada no dia 28/02/2005 nas quatro estações urbanas, analisadas duas a duas.

Durante o período noturno, o rápido resfriamento observado na estação na Fadisc, devido à ocorrência de precipitação no final da tarde, propiciou o registro de diferenças térmicas entre essa estação e às demais, porém inferior a $1,9^{\circ} \mathrm{C}$ (diferença registra entre a estação na Fadisc e no Campus I, às 21:30h).

A leitura horizontal da matriz de análise (Gráfico 29) permitiu observar que as diferenças térmicas entre as estações seguiram tendência semelhante ao dia precedente. A leitura horizontal dos gráficos da estação no Campus mostrou que essa estação apresentou temperaturas do ar mais elevadas que as demais estações durante todo o dia. As maiores diferenças térmicas ocorreu em relação à estação na Fadisc, com picos no início da manhã (horário de aquecimento diurno), próximo ao final da tarde (horário de maior aquecimento do ar) e no meio da noite (horário no qual tem sido mostrado indícios de formação de ilha de calor urbano). 


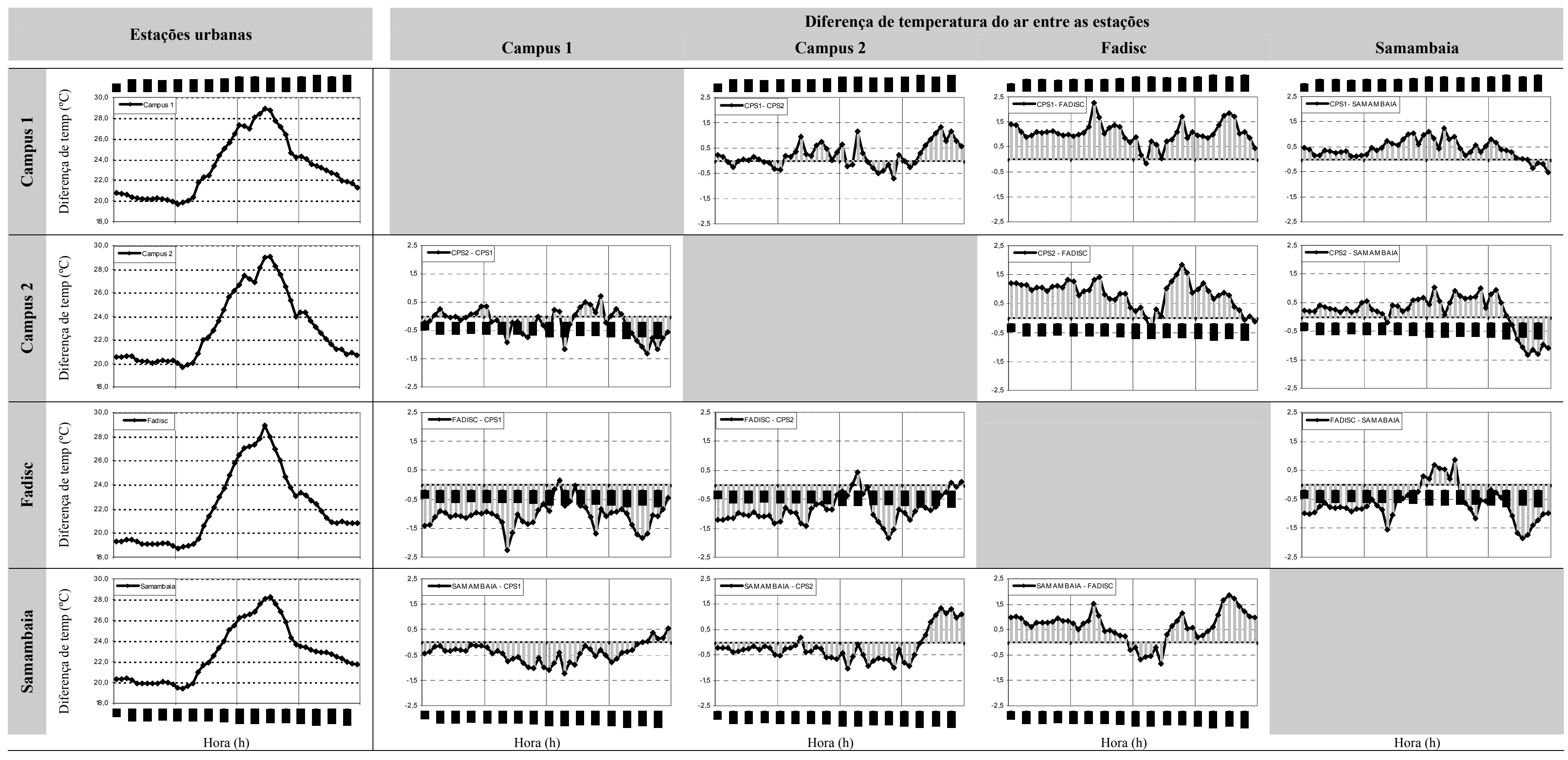

Gráfico 29: Matriz de análise do comportamento térmico das quatro estações automáticas no dia 28/02/2005. A leitura horizontal dos gráficos permite acompanhar o comportamento diário de cada estação em relação às demais, indicando maior ou menor aquecimento do ar de acordo com a projeção acima ou abaixo do eixo das coordenadas, respectivamente, enquanto a leitura vertical dos gráficos permite a análise das estaçôes automáticas tomadas a partir de uma estação de referência, indicada acima de cada coluna. 
Com relação ao desempenho térmico no Campus II, a leitura horizontal dos gráficos da matriz de análise permitiu observar que essa estação apresentou tendência de maior aquecimento do ar em relação às estações na Fadisc e no Samambaia. As maiores diferenças térmicas nessa estação ocorreu em relação à estação na Fadisc, com picos no início da manhã, na ordem de $1,4^{\circ} \mathrm{C}$, e próximo ao final da tarde, na ordem de $1,8^{\circ} \mathrm{C}$. Observou-se, ainda, intenso resfriamento após o pôr-do-sol, indicado nos gráficos pela diferença negativa com relação às estações no Campus I e no Samambaia.

Quanto à estação na Fadisc, observou-se que essa estação permaneceu menos aquecida em relação às demais estações durante todo o dia, exceto no início da tarde, quando essa estação apresentou diferenças térmicas insignificantes com relação às estações no Campus I e no Campus II, e temperatura do ar um pouco mais aquecida, na ordem de $1,4^{\circ} \mathrm{C}$,em relação à estação no Samambaia. As maiores diferenças térmicas foram observadas no início da manhã e no meio da noite, o que indicou o aquecimento mais lento durante o dia e maior perda de radiação calorífica após o pôr-do-sol.

\section{- Dia $1^{\circ}$ de março de 2005}

No dia 01/03/2005, a amplitude térmica diária registrada seguiu a tendência do dia anterior, na ordem de $10,3^{\circ} \mathrm{C}$. A temperatura máxima do ar foi registrada às $16: 00 \mathrm{~h}$, $30,3^{\circ} \mathrm{C}$. A temperatura mínima do ar ocorreu ao nascer do Sol, com registro de $20,0^{\circ} \mathrm{C}$. Os índices de umidade relativa registrados foram mais baixo que os dias precedentes, conseqüência do aumento da média diária da temperatura do ar e redução da quantidade de vapor d'água presente na atmosfera. No início da tarde foi registrado índices abaixo de 50\%, com mínima foi de 44\%, às 16:00h (horário de maior temperatura do ar diária).

O gráfico dos valores horários da radiação solar global apresentou curva parabólica quase contínua, indicando a continuidade de dissipação da nebulosidade, apresentando céu com poucas nuvens. Os valores registrados permaneceram em elevação, se aproximando dos valores registrados antes do avanço do sistema frontal sobre a região. O valor máximo registrado foi de $926 \mathrm{~W} / \mathrm{m}^{2}$, às $13: 00 \mathrm{~h}$, com média diária de $272,1 \mathrm{~W} / \mathrm{m}^{2}$, ao longo de 13 horas de insolação. A pressão atmosférica variou $4 \mathrm{mb}$, seguindo a tendência de elevação da máxima, registrada às 11:00h (934mb), e da mínima, registrada a partir das 17:00h permanecendo até às 19:00h (930mb). 
Os ventos predominantes foram do quadrante SE, indicando a presença da massa Polar Atlântica sobre a região, ainda que em fase de tropicalização. Durante a madrugada houve longo período de calmaria. Os ventos do quadrante SE sopraram a partir do início da manhã sob a forma de aragem. À tarde observou-se incremento na velocidade do ar com rajadas de até $4 \mathrm{~m} / \mathrm{s}$, adquirindo característica de brisa fraca. Entretanto, durante o período noturno os ventos alcançaram rajadas de até $6 \mathrm{~m} / \mathrm{s}$, caracterizando-se como brisa moderada. $\mathrm{O}$ incremento na velocidade do ar no período noturno possivelmente foi indício de avanço de novo sistema frontal que chegou à região de São Carlos no dia seguinte.

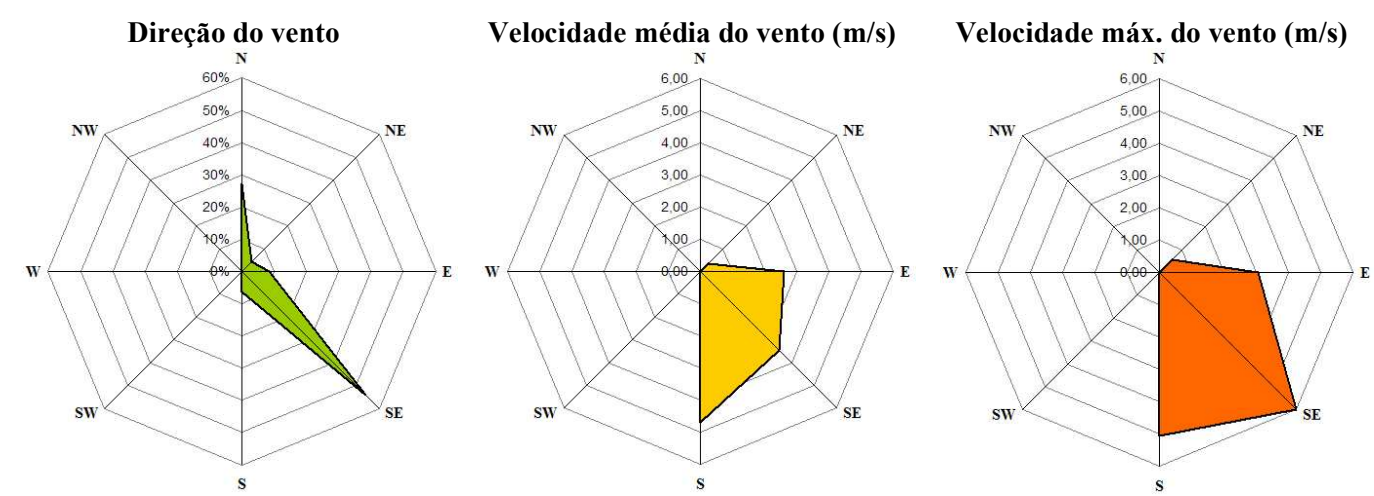

Figura 38: Rosa dos ventos com a dinâmica da circulação do ar no dia 01/03/2005, obtidos por meio de registros de direção e velocidade dos ventos tomados por média a cada 30 minutos pela estação automática localizada no Campus I.

Neste sentido, observou-se que o cenário atmosférico permaneceu em fase de transição, característica da fase de tropicalização da massa Polar Atlântica. A imagem do canal infravermelho do satélite GOES-12 atestou a continuidade de dissipação da nebulosidade que dominou sobre a região de São Carlos após o avanço da frente Polar Atlântica no dia 25/02/2005. A carta de pressão ao nível do mar registrou o avanço de novo sistema frontal no Sul do Brasil (Figura 39), o qual chegou à região Sudeste no dia seguinte, iniciando novo episódio climático.

Nesse dia, o comportamento da temperatura do ar registrada nas quatro estações urbanas apresentou significativas diferenças de temperaturas do ar, principalmente ao nascer do Sol e no horário de maior aquecimento do ar. Esse comportamento foi resultado da dissipação da nebulosidade presente nos dias anteriores e redução na quantidade de vapor d'água presente na atmosfera, característico da fase de tropicalização. 
(a)

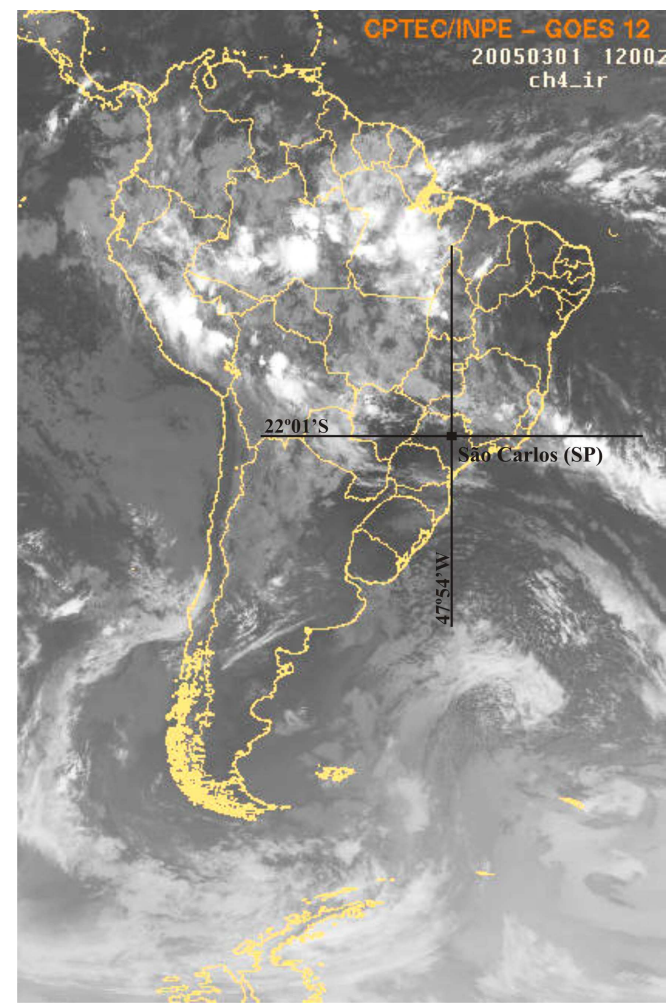

(b)

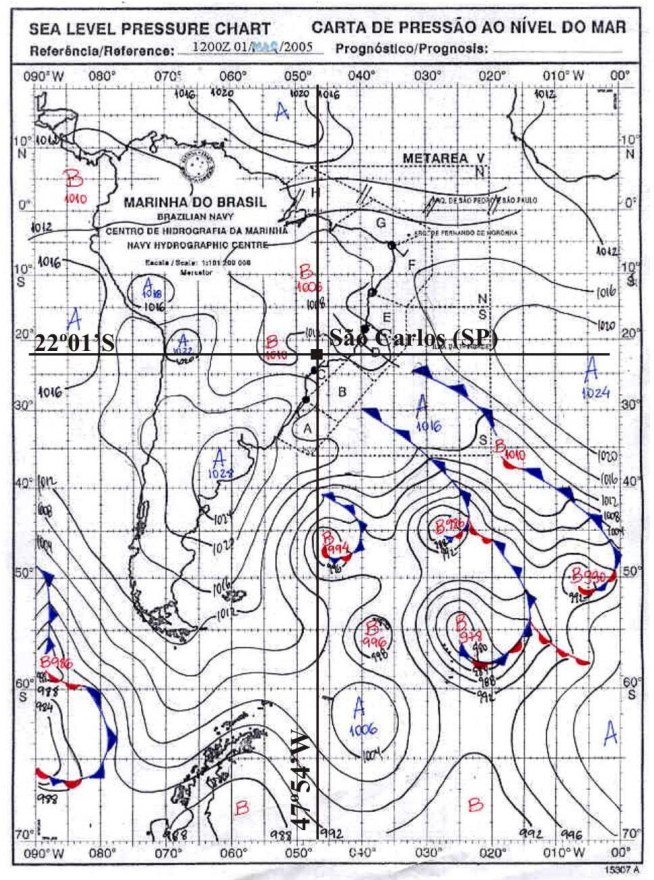

(c)
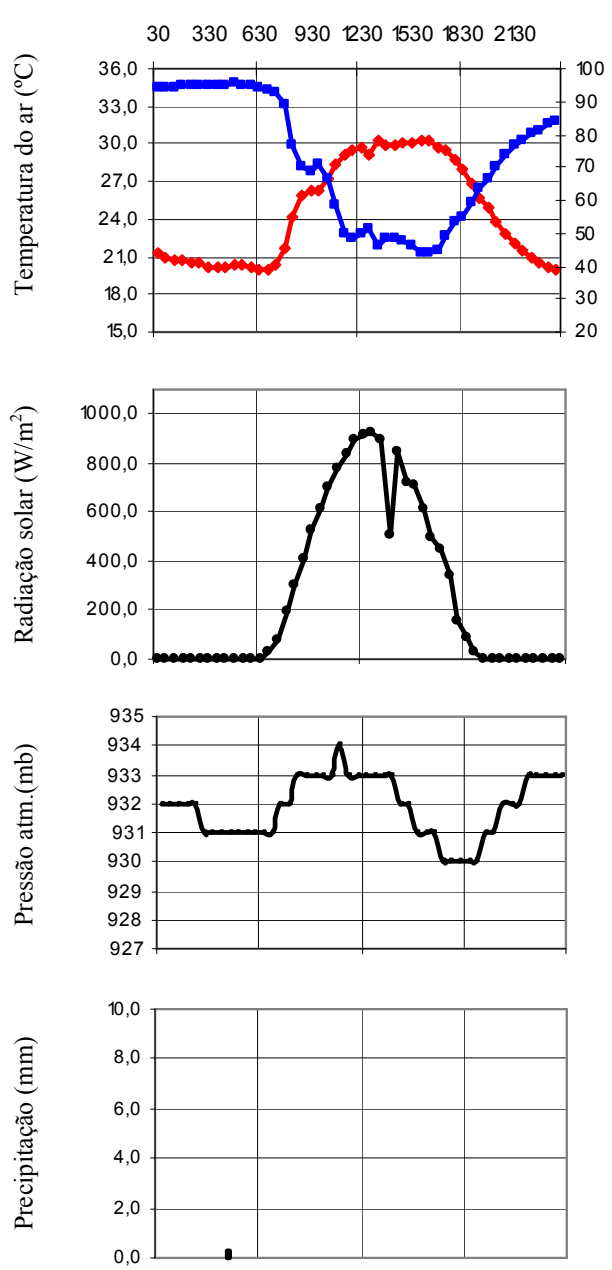

Direção do ar $\uparrow \uparrow \uparrow \uparrow \searrow \searrow \searrow \searrow \searrow$

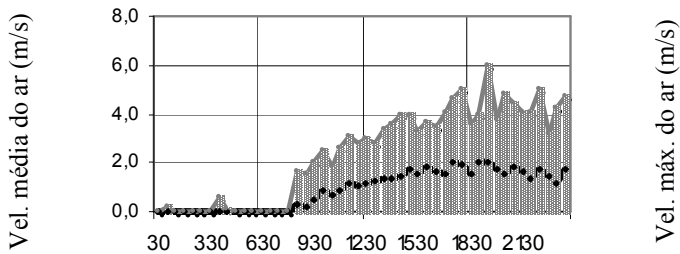

Legenda:

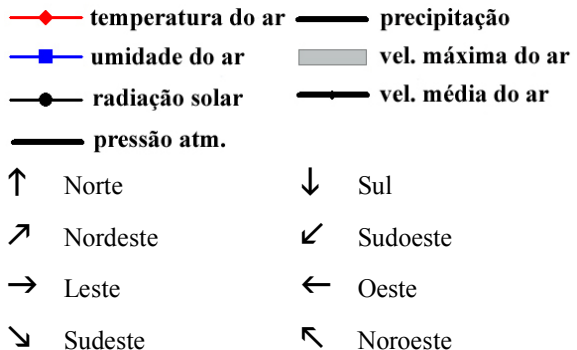

Figura 39: Imagem do satélite GOES-12, canal 4 (infravermelho), e carta de pressão ao nível do mar às 9:00h (horário local) do dia 01/03/2005 e análise rítmica horária com registro dos elementos climáticos tomados a cada 30 minutos. 


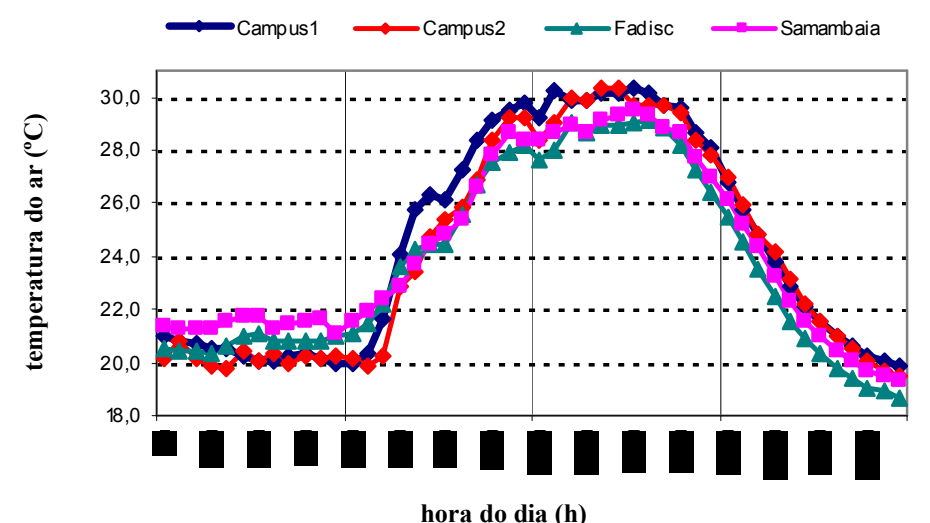

Gráfico 30: Comportamento da temperatura do ar registrada no dia 01/03/2005 nas quatro estações urbanas.

Durante a madrugada, os valores de temperatura do ar permaneceram praticamente estáveis em todas as estações até o nascer do Sol, apesar da pouca nebulosidade, da leve precipitação e da calmaria. O resfriamento mais acentuado ocorreu na estação no Campus II, como observado nos dias 20/02/2005 e 21/02/2005, também na fase de tropicalização. A estação no Samambaia apresentou as maiores temperaturas do ar nesses horários, evidenciando menor perda de radiação calorífica para a atmosfera.

Após o nascer do Sol, a estação no Campus I voltou a apresentar aquecimento acentuado, o que não ocorreu nas fase de avanço e de domínio da Polar Atlântica. As demais estações apresentaram aquecimento gradual e contínuo até atingir a temperatura máxima próximo às $15: 00 \mathrm{~h}$. As estações no Campus I e no Campus II apresentaram maiores máximas: $30,3^{\circ} \mathrm{C}$ e $30,4^{\circ} \mathrm{C}$, respectivamente. Entretanto, a diferença de temperatura entre as outras duas estações foram próxima a $1^{\circ} \mathrm{C}$.

Após o pôr-do-sol, houve tendência de resfriamento acentuado em todas as estações. A estação na Fadisc continuou apresentando menor temperatura do ar em relação às demais estações, porém apresentando comportamento análogo na perda de radiação calorífica noturna. As demais estações apresentaram valores de temperatura do ar semelhantes, indicando a conformação de um campo térmico homogêneo e a não formação de ilhas de calor urbana nesse dia, apesar a elevada amplitude térmica diária em todas as estações.

O Gráfico 31 apresenta as diferenças de temperatura do ar observada entre as estações automáticas, duas a duas, ao longo o dia 21/02/2005. A partir da análise dos gráficos observou-se que as diferenças de temperatura do ar entre as estações continuaram pequenas, apesar da maior dissipação da nebulosidade. Durante a madrugada, as diferenças térmicas entre as estações foram inferiores a $1,7^{\circ} \mathrm{C}$, 
registrada entre as estações no Campus I e no Samambaia e entre as estações no Campus II e no Samambaia, ambas às $3: 30 \mathrm{~h}$. As diferenças de temperatura do ar registradas durante a madrugada foram favorecidas pela ocorrência de calmaria nesse período do dia.

a)

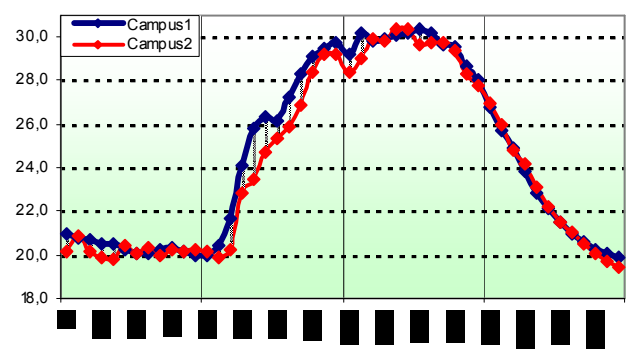

c)

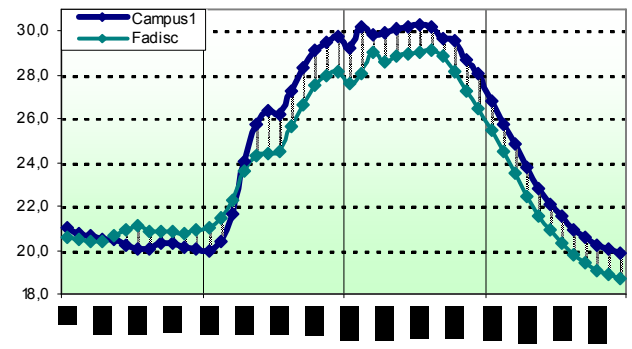

e)

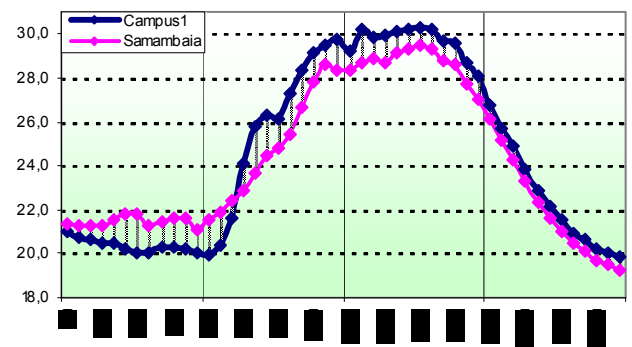

b)

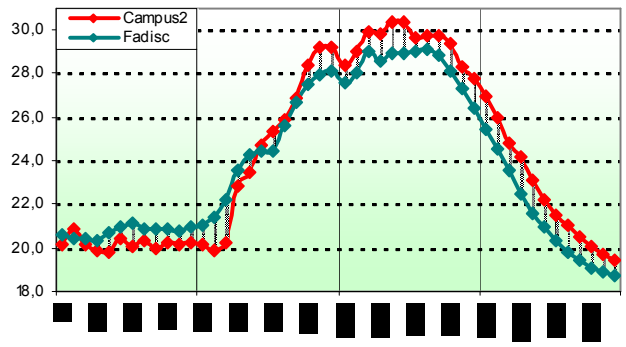

d)

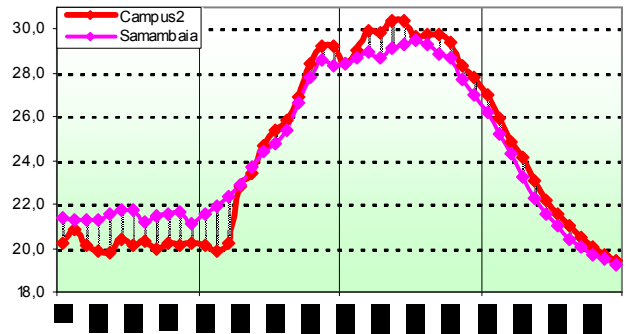

f)

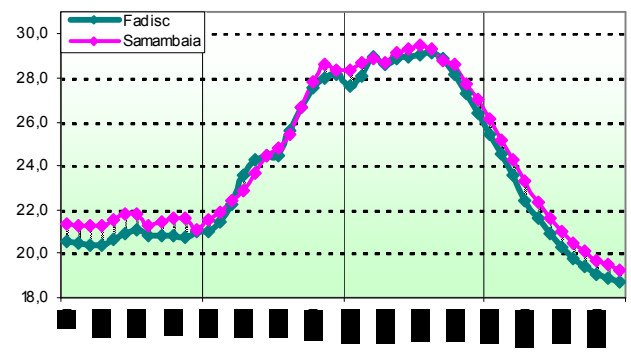

Gráfico 31: Diferenças no comportamento da temperatura do ar registrada no dia 01/03/2005 nas quatro estações urbanas, analisadas duas a duas.

Entretanto, as maiores diferenças térmicas entre as estações foram observadas no início da manhã, como notado no dia precedente, devido ao atraso térmico registrado nas estações no Samambaia em relação ao aquecimento do ar no Campus I e no Campus II. Dessa forma, foram registradas diferenças térmicas na ordem de $2,4^{\circ} \mathrm{C}$, entre as estações no Campus II e no Samambaia, e diferenças térmicas na ordem de $2,1^{\circ} \mathrm{C}$, entre as estações no Campus I e no Samambaia, ambos às 8:30h.

A leitura horizontal da matriz de análise (Gráfico 32) permitiu observar o desempenho térmico nas quatro estações analisadas. Observou-se, assim, que as estações apresentam maiores diferenças térmicas entre si em relação ao dia precedente, fato que sugere maior heterogeneidade no campo térmico urbano com possível formação de ilhas de calor em alguns pontos da cidade. 
Com relação à estação no Campus I, observou-se que essa estação apresentou maior resfriamento do ar durante a madrugada - fato observado apenas em período de céu claro. Esse resultado sugere que a região do Campus I apresenta maior capacidade de troca de energia calorífica com a abóbada celeste, porém de forma lenta. Porém, a partir do nascer do Sol, a estação no Campus I apresentou-se mais aquecida em relação às demais estações - tendência também observada nos dias 20 e 21/02/2005.

Quanto ao desempenho térmico da estação no Campus II, a análise dos gráficos permitiu observar que essa estação intenso resfriamento durante a madrugada, favorecido pela permanência de céu claro, que possibilitou maior troca de energia calorífica com a abóbada celeste. Entretanto, após o nascer do Sol, a estação no Campus II apresentou diferenças térmicas positivas, com diferenças térmicas acentuadas com relação à estação na Fadisc, sobretudo após o pôr-do-sol.

Os gráficos da estação na Fadisc evidenciaram maiores diferenças térmicas em relação à estação no Campus I, apresentando-se mais aquecido durante a madrugada e menores temperaturas ao longo do dia. Notou-se, ainda, o comportamento térmico semelhantes entre a estação na Fadisc e a estação no Samambaia durante todo o dia, com diferenças térmicas inferiores a $0,9^{\circ} \mathrm{C}$. 


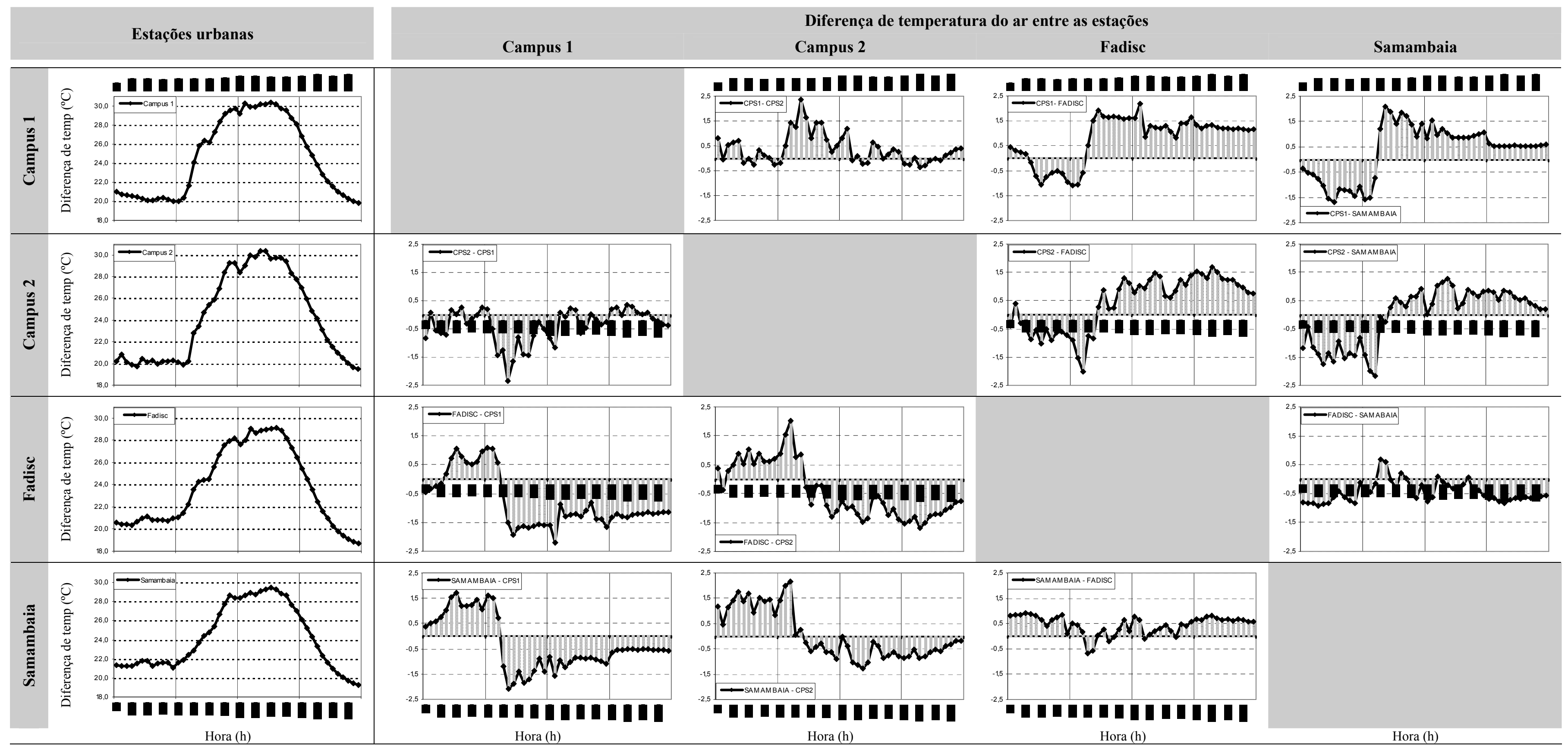

Gráfico 32: Matriz de análise do comportamento térmico das quatro estações automáticas no dia 01/03/2005. A leitura horizontal dos gráficos permite acompanhar o comportamento diário de cada estação em relação às demais, indicando maior ou menor aquecimento do ar de acordo com a projeção acima ou abaixo do eixo das coordenadas, respectivamente, enquanto a leitura vertical dos gráficos permite a análise das estaçôes automáticas tomadas a partir de uma estação de referência, indicada acima de cada coluna. 


\section{Conclusões}

A investigação em tela constatou o comportamento térmico diferenciado em diferentes regiões da cidade de São Carlos, no período de verão, evidenciando a influência das características do entorno construído nas condições térmicas locais. Os resultados obtidos forneceram maior compreensão da configuração do campo térmico urbano nas suas dimensões espaços-temporais, por meio da intensidade da ilha de calor urbana em quatro regiões da cidade dentro de suas variações diurnas e das diferentes condições impostas pelos tipos de tempo habituais do período de verão.

O aporte da abordagem dinâmica do clima permitiu identificar e caracterizar os tipos de tempo habituais do período de verão compreendidos em episódios representativos do fato climático para a região de São Carlos. Assim, o estudo do comportamento térmico diário nas quatro estações automáticas instaladas dentro da malha urbana foi realizado ao longo de um episódio climático representativo, com dados totalizados em intervalos de 30 minutos, o qual permitiu maior precisão nas análises.

A partir dos resultados obtidos, observou-se que a variação na intensidade das ilhas de calor urbano, identificadas pelas diferenças térmicas entre as regiões monitoradas, apresentou estreita relação com o cenário atmosférico imposto pelos diferentes tipos de tempo. Essa constatação conduziu a considerar que, antes das características do entorno construído, as condições atmosféricas características dos diferentes tipos de tempo favorecem às diferentes conformações do campo térmico urbano.

Nesse sentido, observou-se que na fase de tropicalização, a presença de nebulosidade e a elevada disponibilidade de vapor d'água na atmosfera, traduzida pelos elevados índices de umidade relativa do ar, favoreceram a conformação de um campo térmico homogêneo nos dias 20 e 21/02/2005. O comportamento térmico entre as estações foram semelhantes entre si, com pequenas variações de temperatura do ar ao longo do dia entre as regiões monitoradas.

Sob essas condições atmosféricas, a estação no Campus I apresentou-se um pouco mais aquecida em relação às demais estações, sobretudo no horário de maior 
aquecimento do ar (15:00h), apresentando diferenças térmicas até 2,3ํㅡ com relação à estação na Fadisc. Durante o período noturno, a diferença de temperatura do ar entre essas duas estações foi mais acentuada, chegando a $3,2^{\circ} \mathrm{C}$, no dia $20 / 02 / 2005$, às 20:30h, o que denotou a formação de ilha de calor urbano na região do Campus I.

Na fase de domínio da massa Tropical Atlântica, a combinação de condições atmosféricas com baixa umidade do ar e permanência de céu claro ao longo do dia, favoreceu à conformação de um campo térmico homogêneo durante o período diurno, devido à forte incidência de radiação solar direta e conseqüente aquecimento das superfícies urbanas; e à conformação de um campo térmico heterogêneo durante a madrugada e à noite, com indícios de ilhas de calor urbano.

A conformação homogênea do campo térmico durante o período diurno foi observada por meio das reduzidas diferenças térmicas entre as quatro estações urbanas analisadas. Nos dias 22 e 23/02/2005 as diferenças térmicas entre as estações foram inferiores a $1,5^{\circ} \mathrm{C}$, registrada entre as estações no Campus I e na Fadisc, no dia 22/02/2005, às 15:00h. Em vários horários no período da tarde as diferenças térmicas chegaram a ser nula, evidenciando o elevado aquecimento do ar e o acúmulo de energia calorífica em todas as estações.

Entretanto, após o pôr-do-sol e durante a madrugada, o comportamento térmico nas estações apresentaram-se diferentes devido, sobretudo, às características do entorno que favoreceram a maior ou a menor perda de energia calorífica armazenada para a abóbada celeste. Assim, observou-se aumento significativo nas diferenças de temperatura do ar entre as quatro áreas analisadas, indicando a conformação de um campo térmico heterogêneo, com indícios de formação de ilhas de calor urbano em algumas áreas da cidade.

Nesse sentido, observou-se que, apesar das condições atmosféricas favoráveis a perda de calor armazenado pelas superfícies urbanas, as estações na Fadisc e no Samambaia apresentaram reduzida perda de radiação calorífica após o pôr-do-sol, permanecendo com temperaturas do ar próxima aos $25^{\circ} \mathrm{C}$, ao tempo que a estação no Campus II apresentou acentuado resfriamento após o pôr-do-sol. A estação no Campus I também apresentou resfriamento significativo, porém menos acentuado do que o observado no Campus II.

O comportamento térmico diferenciado nas quatro estações resultou em diferenças térmicas próximas aos $5^{\circ} \mathrm{C}$ entre as estações no Campus II e no Samambaia e próximas aos $4^{\circ} \mathrm{C}$ entre as estações no Campus II e na Fadisc, poucas horas após o pôr-do-sol e durante a madrugada, sobretudo próximo ao nascer do Sol, quando ocorre a menor temperatura do ar. 
Observou-se, ainda, que as diferenças térmicas entre as estações observadas durante a madrugada e após o pôr-do-sol foram favorecidas pela ocorrência de calmaria, além da permanência de céu claro, propiciando a formação de ilhas de calor urbano com maior intensidade entre às 20:00h e 22:00h e no início da manhã, porém com temperaturas mais amenas.

Por fim, observou-se que o período de maior aquecimento do ar ocorreu entre as 7:00h e às 9:00h, quando há maior elevação solar e conseqüente aquecimento das superfícies urbanas. As estações no Campus I e no Campus II apresentaram acentuado aquecimento nesses horários, com variação térmica superior a $9^{\circ} \mathrm{C}$, enquanto as estações na Fadisc e no Samambaia apresentaram aquecimento mais lento, possivelmente devido à massa arbórea e à baixa densidade de construções.

$\mathrm{Na}$ fase de prenúncio, caracterizado como um dia extremamente quente e seco, o acentuado aquecimento do ar característico dessa fase e a ocorrência de nebulosidade que prenunciou o avanço de um sistema frontal sobre a região favoreceram à formação de um campo térmico homogêneo durante o período diurno, sobretudo, após o pôr-do-sol, quando as condições de céu claro da fase de domínio da massa Tropical Atlântica propiciou à formação de ilhas de calor urbana em algumas áreas da cidade.

A conformação de um campo térmico heterogêneo foi observada, apenas, durante a madrugada, quando a massa Tropical Atlântica ainda determinava as condições atmosféricas. Nesses horários, observaram-se grandes diferenças térmicas entre as estações urbanas analisadas, sobretudo nos horários próximo ao nascer do Sol, quando as diferenças foram mais acentuadas. Essas diferenças térmicas, as quais chegaram próximas a 5ํ em alguns horários, indicaram a formação de ilhas de calor urbano sobre as regiões da Fadisc e do Samambaia. Entretanto, as temperaturas nessas ilhas de calor foram inferiores a $24^{\circ} \mathrm{C}$, devido ao menor aquecimento do ar nesses horários.

Durante o período de aquecimento matinal, observado entre 7:00 e 9:00h, as estações no Campus I e no Campus II apresentaram intenso aquecimento do ar, chegando a apresentar variação de temperatura de $9^{\circ} \mathrm{C}$ em duas horas. $\mathrm{O}$ maior aquecimento deveu-se às características de ocupação do solo mais adensado nessas duas áreas em relação às estações da Fadisc e do Samambaia que apresentam maior massa arbórea e menor índice de solo pavimentado, resultado em um aquecimento do ar mais lento.

As condições atmosféricas de baixa umidade do ar, permanência de céu claro ao longo do dia e elevada incidência de radiação solar direta continuaram durante a 
manhã e o início da tarde. A combinação dessas condições atmosféricas com o aquecimento pré-frontal característico da fase de prenúncio propiciaram à conformação de um campo térmico menos homogêneo do que ao observado na fase de domínio de massa Tropical Atlântica. As diferenças térmicas entre as estações chegaram a $2,4^{\circ} \mathrm{C}$, às $15: 30 \mathrm{~h}$, com as estações no Campus I e no Campus II apresentando as maiores temperaturas do ar. Entretanto, as diferenças térmicas se anularam com a formação de forte nebulosidade sobre a região, às 15:00h, contribuindo para a formação de um campo térmico homogêneo, sem indícios de ilhas de calor urbana, como observado nos dias precedentes.

Assim, observou-se que a perda noturna de radiação calorífica ocorreu de forma lenta e gradual em todas as estações, devido à intensa nebulosidade que dificultou a troca de energia calorífica por radiação entre as superfícies urbanas e a abóbada celeste.

Na fase de avanço, o comportamento do campo térmico pode-se analisado em dois momentos completamente distintos: antes e após o avanço da frente Polar Atlântica sobre a região de estudo. Antes do avanço do sistema frontal, o campo térmico urbano comportou-se análogo ao dia precedente, uma vez que o cenário atmosférico apresentava condições de tipo de tempo imposto pela massa Tropical Atlântica, porém com a nebulosidade característica da fase de prenúncio.

Sob essas condições atmosféricas, o campo térmico urbano apresentou-se homogêneo, com reduzida diferença térmica entre as quatro estações urbanas analisadas. Entretanto, diferente da tendência observada nos demais dias analisados, a temperatura do ar tenderam a um pequeno aumento durante a madrugada, possivelmente oriundo da perda de calor sensível pelas nuvens que encobriam a região de estudo e ao calor armazenado pelas superfícies urbanas que, ao ser liberado por radiação para a atmosfera mais fria, permaneceu na camada intra-urbana devido à nebulosidade.

Durante o período diurno, o campo térmico permaneceu homogêneo devido à nebulosidade, que dificultou a incidência de radiação solar direta sobre as superfícies, evitando, dessa forma, maior aquecimento do ar por energia calorífica reemitida pelas superfícies urbanas. Assim, sob as condições atmosféricas de prenúncio, com forte nebulosidade, o aquecimento do ar deu-se, essencialmente, pelo fenômeno de convecção atmosférica provocada pela aproximação do sistema frontal, conhecido como aquecimento pré-frontal. Sob essas condições atmosféricas, as características do entorno construído apresentou menor influência na configuração do campo térmico 
urbano, traduzido pelas pequenas diferenças térmicas entre as estações, inferiores a $1,7^{\circ} \mathrm{C}$.

No momento de entrada da Frente Polar Atlântica sobre a região, todas as estações apresentaram resposta térmica imediata, com queda acentuada de temperatura do ar. Após o avanço do sistema frontal, observou-se a configuração de um campo térmico homogêneo, mesmo após o pôr-do-sol, favorecido pela forte nebulosidade, pelo incremento na umidade do ar e pela ocorrência de precipitação.

Dessa forma, observou-se que o cenário atmosférico característico da fase de avanço favoreceu, de forma significativa, à homogeneidade do campo térmico urbano ao longo do dia. As quatro estações urbanas analisadas apresentaram comportamento térmico semelhantes, apresentando pequenas diferenças térmicas.

Na fase de domínio da massa Polar Atlântica observou-se a conformação de campo térmico homogêneo ao longo de todo o dia, favorecido pela forte nebulosidade e aumento de vapor d'água na atmosfera, traduzido pelo índice de umidade relativa do ar acima dos $70 \%$. Nos dias 26 e 27/02/2005, o comportamento da temperatura do ar entre as quatro estações foi bastante semelhante, com aquecimento matinal mais lento, independente das características do entorno construído. Durante o período diurno, observou-se pequenas diferenças térmicas entre as estações proporcionado pelo reduzido aquecimento do ar devido à baixa incidência de radiação solar direta em conseqüência da nebulosidade. As diferenças térmicas continuaram pequenas após o pôr-do-sol, o que configurou maior homogeneidade do campo térmico urbano, com ausência de ilhas de calor. As diferenças térmicas observadas sob as condições de domínio da massa Polar Atlântica foram inferiores a $3^{\circ} \mathrm{C}$, registrado entre as estações no Campus II e na Fadisc, no dia 27/02/2005, às 15:00h., momentos antes de ocorrência de precipitação.

Após a análise do comportamento térmico ao longo de todo episódio, constatou-se que a maior intensidade da ilha de calor urbano no período de verão, em São Carlos, ocorre na atuação da massa Tropical Atlântica sobre a região. Nessa fase, o tipo de tempo habitual é caracterizado por cenário atmosférico com predominância de céu claro, alta incidência de radiação solar direta e valores de temperatura do ar elevados com máxima diária acima da média das máximas indicadas pelas Normais Climatológicas. Sob essas condições, observou-se que as características do entorno construído exercem maior influência no comportamento térmico urbano. Nesse caso, as diferenças térmicas entre diferentes regiões dentro da malha urbana de São Carlos podem ser superiores a $5^{\circ} \mathrm{C}$. 
Observou-se, ainda, que as maiores diferenças térmicas ocorreram próximo ao nascer do Sol, no momento de menor aquecimento do ar, e após o pôr-do-sol, das $21: 30 \mathrm{~h}$ às $22: 00 \mathrm{~h}$. Contudo, as elevadas diferenças térmicas registradas próximo ao nascer do Sol não podem ser consideradas indícios de ilhas de calor, uma vez que os valores de temperatura do ar nesses horários são reduzidos, não implicando necessariamente em bolsões de ar aquecidos. Em contrapartida, as diferenças térmicas observadas após o pôr-do-sol foram indícios de troca de energia térmica por radiação entre as superfícies urbanas e a abóbada celeste, em decorrência do armazenamento de calor pela massa edificada, caracterizando, assim, ilhas de calor urbano.

Dessa forma, conclui-se que os objetivos iniciais propostos dessa tese foram alcançados. Salienta-se que, embora a análise tenha se limitado a dez dias do período de verão, o ritmo impresso pelos tipos de tempos no episódio delineado caracterizou-o como representativo do fato climático, o que garantiu-nos a validade das conclusões obtidas, o que não implica no esgotamento de todas as possibilidades que as várias combinações de fluxos atmosféricos podem produzir na escala local, com repercussões no ambiente urbano e seu campo térmico.

Dessa forma, são sugeridas algumas recomendações que visam à continuidade da presente pesquisa:

- Análise do campo térmico urbano de São Carlos em episódios climáticos característicos do período de primavera e de outono, com vistas a complementar as informações obtidas para o período de verão (presente tese) e de inverno (tese de doutoramento da física Ludimila Fabiana da Silva, em desenvolvimento);

- Estudo da espacialização do campo térmico urbano por meio de monitoramento contínuo dos valores de temperatura do ar tomados em superfície em vários pontos da cidade distribuídos em malha que permita a visualização contínua do campo térmico;

- Estudo da espacialização do campo térmico urbano por meio de sensoriamento remoto termal e análise do balanço energético urbano por meio de imagens de satélite - bandas termais;

Por fim, deve- se considerar que o clima urbano constitui-se apenas uma das múltiplas facetas da qualidade ambiental urbana, mas seu estudo torna-se fundamental como uma contribuição ao planejamento urbano, que por sua vez pode conduzir à uma melhoria na qualidade de vida da população. Esta é a finalidade de grande parte dos estudos realizados na cidade dentro de referida temática e foi a motivação precípua do presente estudo. 


\section{Referências}

AGUIAR, R. L. (1989). Mapeamento geotécnico da área de expansão urbana de São Carlos-SP. contribuição ao planejamento. 1989. 2v. Dissertação (Mestrado) - Escola de Engenharia de São Carlos, Universidade de São Paulo, São Carlos.

ALCOFORADO, M. J.; LOPES, A., ANDRADE, H.;VASCONCELOS, J. (2006). Orientações Climáticas para o Ordenamento em Lisboa. Universidade de Lisboa Centros de Estudos Geográficos.

ALMEIDA, F. F. M. (1964). Fundamentos geológicos do relevo paulista. São Paulo: Instituto de Geografia, Universidade de São Paulo (Série Teses e Monografias).

AMORIM, M. C. C. T.; SANT'ANNA NETO, J. L.; DUBREUIL, V. (2009). Estrutura térmica identificada por transectos móveis e canal termal do Landsat 7 em cidade tropical. Revista de Geografia Norte Grande, n.43, p.65-80.

ARNFIELD, A. J. (2003). Two decades of urban climate research: a review of turbulence, exchanges of energy and water, and the urban heat island. International Journal of Climatology, 23, p.1-26.

ASSIS, E. S.; PEREIRA, I. M. (2005). AET6: levantamento das publicações existentes sobre o tema clima urbano, conforto ambiental e eficiência energética. Relatório Técnico para a Eletrobrás, Belo Horizonte: Universidade Federal de Minas Gerais. [Trabalho coordenado pelo prof. Leonardo Bittencourt, Universidade Federal de Alagoas].

AYOADE, J. O. (1996). Introdução à Climatologia para os trópicos. 4. ed. - Rio de Janeiro: Bertrand do Brasil.

BORTOLUCCI, A. A. (1983). Caracterização geológico-geotécnica da região urbana de São Carlos-SP, a partir de sondagens de simples reconhecimento. 1983. $67 \mathrm{f}$.

Dissertação (Mestrado em Geotecnia) - Escola de Engenharia de São Carlos, Universidade de São Paulo, São Carlos. 
BORTOLUCCI, M. A. P. C. S. (1991). Moradias urbanas construídas em São Carlos no período cafeeiro. 1991. 2 v. São Paulo. Tese (Doutorado em Arquitetura e Urbanismo) Faculdade de Arquitetura e Urbanismo, Universidade de São Paulo, São Paulo.

BRANDÃO, A. M. P. M. (1987). Tendências e oscilações climáticas na área metropolitana do Rio de Janeiro. 1987. 2v. Dissertação (Mestrado em Geografia) Faculdade de Filosofia, Letras e Ciências Humanas, Universidade de São Paulo, São Paulo.

BRANDÃO, A. M. P. M. (1996). O clima urbano da cidade do Rio de Janeiro. 1996. 362p. Tese (Doutorado em Geografia Física) - Faculdade de Filosofia, Letras e Ciências Humanas, Universidade de São Paulo, São Paulo.

BRASIL (1992). Ministério da Agricultura e Reforma Agrária (Secretaria Nacional de Irrigação. Departamento Nacional de Meteorologia). Normais climatológicas (19611990). Brasília: DNMET.

CAMARGO, J. C. G.; TAVARES, A. C. (1985). Influência da cidade de Rio Claro na temperatura e na umidade do ar. Geografia, 10(20), p. 149-168.

CARLOS, A. F. A.(1992). A cidade. São Paulo: Contexto.

CLIMANÁLISE: boletim de monitoramento e análise climática (2005). Cachoeira Paulista, SP: CPTEC/INPE, v. 20, n. 2. Disponível em:

<http://antartica.cptec.inpe.br/ rantar/climanalise/0205/>. Acesso em: 23 jan. 2008.

CONTI, J. B. (1979). Crescimento urbano e mudanças climáticas. Suplemento Cultural do Estado de São Paulo. n. 179, ano III, 3.

DANI, I. M. (1987). Aspectos temporo-espaciais da temperatura e umidade relativa em Porto Alegre em janeiro de 1982. contribuição ao estudo do clima urbano. 1987. 2v. Dissertação (Mestrado em Geografia) - Faculdade de Filosofia, Letras e Ciências Humanas, Universidade de São Paulo, São Paulo.

DINES, M. (1991). Climatologia urbana e o desenho das cidades: insumos para o planejamento da metrópole paulistana. 1991. 168 f. Dissertação (Mestrado em Arquitetura e Urbanismo) - Faculdade de Arquitetura e Urbanismo, Universidade de São Paulo, São Paulo.

DINES, M. (1991). Climatologia urbana e o desenho das cidades: insumos para o planejamento da metrópole paulistana. 1991. 168 f. Dissertação (Mestrado em 
Arquitetura e Urbanismo) - Faculdade de Arquitetura e Urbanismo, Universidade de São Paulo, São Paulo.

ELNAHAS, M. M. (1999). How do planners and architects deal with conflicting climate design objectives? In: XVI, PLEA (Passive and Low Energy Architecture), Austrália. Anais... v.1, p.225-230.

FONTES, M.S.G.C. (1998). Efeito climático das áreas de fundo de vale no ambiente urbano: o caso de São Carlos-SP. 1998. 122 f. Tese (Doutorado em Ciências da Engenharia Ambiental) - Escola de Engenharia de São Carlos, Universidade de São Paulo, São Carlos.

FONZAR, B. C. (1981). O processo de ocupação regional, o modelo urbano e o conforto térmico na Alta-Sorocabana: um teste aplicado a Presidente Prudente/SP. 1981. 156p. Dissertação (Mestrado em Geografia) - Faculdade de Filosofia, Letras e Ciências Humanas, Universidade de São Paulo, São Paulo.

GALLEGO, L. P. (1972). Tipos de tempo e poluição atmosférica no Rio de Janeiro: um ensaio em climatologia urbana. 1972. 104p. Tese (Doutorado em Geografia) Faculdade de Filosofia, Letras e Ciências Humanas, Universidade de São Paulo, São Paulo.

GOTTDIENER, M. (1993). A produção social do espaço urbano. São Paulo: EDUSP. HOUGH, M. (1998). Naturaleza y ciudad. planificación urbana y procesos ecológicos. Barcelona: Gustavo Gili.

IBGE - INSTITUTO BRASILEIRO DE GEOGRAFIA E ESTATÍSTICA (2009). Cidades: Resultados do Universo - Censo 2000. Disponível em:

<http://www.ibge.gov.br/cidadesat/topwindow.htm?1>. Acesso em: 17 set. 2009.

IPT - INSTITUTO DE PESQUISAS TECNOLÓGICAS DO ESTADO DE SÃO PAULO (1981). Mapa geomorfológico do estado de São Paulo. Escala 1/500.000. v.1. (texto). São Paulo.

JUNOT. L. R. (1943). As chuvas da cidade de São Paulo. São Paulo: Siqueira.

KATZSCHNER, L. (1997). Urban climate studies as tools for urban planning and architecture. In: ENCONTRO NACIONAL DE CONFORTO NO AMBIENTE CONSTRUÍDO, 5. 1997. Salvador. Anais... , p.49-58. 
LANDSBERG, H. E. (2006). O clima das cidades. Revista do Departamento de Geografia, v.18, p.95-111. Tradução: Tarik Rezende de Azevedo; Revisão: Maia Elisa Siqueira Silva.

LOMBARDO, M. A. (1984). Ilha de calor da metrópole paulistana. 1984. 210p. Tese (Doutorado em Geografia) - Faculdade de Filosofia, Letras e Ciências Humanas, Universidade de São Paulo, São Paulo.

MAITELLI, G. T. (1994). Uma abordagem tridimensional de clima urbano em área tropical continental: o exemplo de Cuiabá-MT. 1994. 204p. Tese (Doutorado em Geografia Física) - Faculdade de Filosofia, Letras e Ciências Humanas, Universidade de São Paulo, São Paulo.

MENDES, H.C. (2005) Urbanização e impactos ambientais: histórico de inundações e alagamentos na bacia do Gregório, São Carlos-SP. 2005. 104 f. Dissertação (Mestrado em Ciências da Engenharia Ambiental) - Escola de Engenharia de São Carlos, Universidade de São Paulo, São Carlos.

MENDONÇA, F. A. (1994). O clima e o planejamento urbano de cidade de porte médio e pequeno: proposição metodológica para estudo e aplicação à cidade de Londrina, PR. 1994. 322p. Tese (Doutorado em Geografia Física) - Faculdade de Filosofia, Letras e Ciências Humanas, Universidade de São Paulo, São Paulo.

MENDONÇA, F. A. (2003a). Os estudo do clima urbano no Brasil. In: Monteiro, C. A de F.; Mendonça, F.(Org.). Clima urbano. São Paulo: Editora Contexto. p. 93-120.

MENDONÇA, F. A. (2003b). Clima e planejamento urbano em Londrina. In: Monteiro, C. A de F.; Mendonça, F.(Org.). Clima urbano. São Paulo: Editora Contexto. p. 93-120.

MIRANDA, E. E. (Coord.) (2005). Sistema de gestão territorial para ABAG/RP. EMBRAPA Monitoramento por Satélite, Campinas. Disponível em: <http://www.cdbrasil.cnpm.embrapa.br> Acesso em:

MONTEIRO, C. A. F. (1975). Teoria e clima urbano. 1975. 219p. Tese (Livre-docência) - Faculdade de Filosofia, Letras e Ciências Humanas, Universidade de São Paulo, São Paulo.

MONTEIRO, C. A. F. (1976). Teoria e clima urbano. São Paulo: IGEOG/USP (Série Teses e Monografias, 25). 
MONTEIRO, C. A. F.; MENDONÇA, F. (Org.) (2003). Clima urbano. São Paulo: Contexto.

MONTEIRO, C. A. F. (1973). A dinâmica climática e as chuvas no Estado de São Paulo: estudo geográfico sob forma de atlas. São Paulo. Instituto de Geografia, Laboratório de Climatologia, Universidade de São Paulo.

MONTEIRO, C. A. F. (1980). Environmental problems in São Paulo metropolitan area: the role of urban climate with special focus on flooding. In: Symposium on Geographical Aspects of Environment, Problems in Highly Urbanized Territories, $24^{\text {th }}$ Int. Geog. Congress, UGI, Japan, 29pp.

MONTEIRO, C. A. F.; TARIFA, J. R. (1977). Contribuição ao estudo do clima de Marabá-PA: uma abordagem de campo subsidiária ao planejamento urbano. São Paulo, Climatologia, n.7, p.1-55.

OKE, T. R. (1988). Street design and urban canopy layer climate. Energy and Buildings. v.11, n.1-3, p.103-113.

OKE, T. R. (1995). The heat island of the urban boundary layer: characteristics, causes and effects. In: CERMAK, J. E. et. al. (Ed.). Wind Climate in Cities. NATO ASI Series E: Applied Sciences, Kluwer Academic Publishers. p.81-107.

OKE, T.R. (1982). The energetic basis of the urban heat island. Quartely Journal of the Royal Meteorological Society, 108, p.1-24.

PASCHOAL, W. (1981). As inundações no Cambuci, bairro de São Paulo. 1981. 157p. Dissertação (Mestrado em Geografia) - Faculdade de Filosofia, Letras e Ciências Humanas, Universidade de São Paulo, São Paulo.

PAZERA JÚNIOR, E. (1976a). A ilha de calor da cidade: fatores e atributos. Rio de Janeiro. Boletim Geográfico, 34 (249), abr.-jun., p.51-57.

PAZERA JUNIOR, E. (1976b). A geografia das relações cidade-campo. Notícia Bibliográfica e Histórica, Campinas, n. 73, mar.-abr., p. 52-57.

PEJON, N. A. D. (2006). Levantamento e Diagnóstico geológico-geotécnico das áreas degradadas na cidade de São Carlos-SP, com auxílio de geoprocessamento. $210 \mathrm{f}$. Tese (Doutorado em Geologia) Escola de Engenharia de São Carlos, Universidade de São Paulo, São Carlos. 
PITTON, S. E. C. (1997). As cidades como indicadoras de alterações térmicas. 1997. 272p. Tese (Doutorado em Geografia Física) - Faculdade de Filosofia, Letras e Ciências Humanas, Universidade de São Paulo, São Paulo.

PMSC - Prefeitura Municipal de São Carlos (2004). Plano Diretor de São Carlos l: diagnóstico da Cidade, Proc. 2146.03, PL 215, Cd-rom.

REBELATTO, D.A.N. (1991). A influência do processo de ocupação do solo na bacia do rio Gregório em São Carlos (SP) sobre a incidência d enchentes nas áreas próximas ao mercado municipal. 104 f. Dissertação (Mestrado em Hidráulica e Saneamento) - Escola de Engenharia de São Carlos, Universidade de São Paulo, São Carlos.

ROSS, J. L. S.; MOROZ, I. C. (1997). Mapa geomorfológico do estado de São Paulo. Escala 1/500.000. Departamento de Geografia. FFLCH-USP-IPT-FAPESP. São Paulo.

SAMPAIO, A. H. L. (1981). Correlação entre uso do solo e ilhas de calor no ambiente urbano: o caso de Salvador. 1981. 103p. Dissertação (Mestrado em Geografia) Faculdade de Filosofia, Letras e Ciências Humanas, Universidade de São Paulo, São Paulo.

SANTOS, J. W. M. C. (1996). O clima urbano de Maringá: ensaio metodológico para cidades de porte médio e pequeno. 1996. 172p. Dissertação (Mestrado em Geografia Física) - Faculdade de Filosofia, Letras e Ciências Humanas, Universidade de São Paulo, São Paulo.

SANTOS, M. (1997). Espaço e método. São Paulo: Nobel.

SÃO PAULO. Universidade de São Paulo - Instituto de Pesquisas Tecnológicas Fundação de Amparo à Pesquisa do Estado de São Paulo. 1997. Mapa geomorfológico do estado de São Paulo. Por: Jurandyr L.S. Ross e Isabel C. Moroz (Coords). São Paulo. 64p. + Map. Color. 1:500.000

SARTORI, M. G. B. (1979). O clima de Santa Maria, RS. do regional ao urbano. 1979. 65p. Dissertação (Mestrado em Geografia) - Faculdade de Filosofia, Letras e Ciências Humanas, Universidade de São Paulo, São Paulo.

SÉ, J.A.S. (1992). O rio do Monjolinho e sua bacia hidrográfica como integradores de sistemas ecológicos: um conjunto de informações para o início de um processo de pesquisas ecológicas, de educação, planejamento e gerenciamento ambientais a longo prazo. [Dissertação de mestrado] EESC/USP 
SETTE, D. M. (1996). O clima urbano de Rondonópolis-MT. 1996. 137p. Dissertação (Mestrado em Geografia Física) - Faculdade de Filosofia, Letras e Ciências Humanas, Universidade de São Paulo, São Paulo.

SOBRAL. H. R. W. (1988). Poluição do ar e doenças respiratórias em crianças da grande São Paulo: um estudo de geografia medica. 1988. 177p. Tese (Doutorado em Geografia) - Faculdade de Filosofia, Letras e Ciências Humanas, Universidade de São Paulo, São Paulo.

SOUZA, L.C.L. (1996). Influência da geometria urbana na temperatura do ar ao nível do pedestre. 1996. 100 f. Tese (Doutorado em Ciências da Engenharia Ambiental) Escola de Engenharia de São Carlos, Universidade de São Paulo, São Carlos.

SOUZA, M. A. de. (1999). A metrópole global? Refletindo sobre São Paulo. In: Souza, M.A. de et al. (orgs). Metrópole e globalização. CEDESP, São Paulo, 254 p.

SPIRN, A. W. (1995). O jardim de granito. São Paulo: EDUSP.

TARIFA, J. R. (1977). Análise comparativa de temperatura e umidade na área urbana e rural de São José dos Campos - SP - Brasil. Geografia, 2(4), p. 59-80.

TAVARES, A. C. (1975). Clima local de Campinas: introdução ao estudo do clima urbano. 180p. Dissertação (Mestrado em Geografia) - Faculdade de Filosofia, Letras e Ciências Humanas, Universidade de São Paulo, São Paulo.

TAVARES, A. C.; PROCHNOW, C. A. C. (1997). Atlas climático de Rio Claro - SP 1996. Rio Claro: (s.n.).

TAVARES, A. C.; SILVA, A. C. F. (2008). Urbanização, chuvas de verão e inundações: uma análise episódica. Revista Climatologia e Estudos da Paisagem, v.3, n.1, p.4-18.

TITARELLI, A. H. V. (1982). Alterações do clima local nos centros urbanos: efeitos adversos da urbanização. Caderno Prudentino de Geografia. Presidente Prudente, 3, p. $28-35$.

TITARELLI, A. H. V. (1982). Alterações de clima local dos centros urbanos: efeitos adversos da urbanização. Caderno Prudentino de Geografia, n.3.

TOLENTINO, M. (1967). Estudo crítico sobre o clima da região de São Carlos. São Carlos: s.ed. (Concurso de monografias). 
VECCHIA, F. A. S. (1997). Clima e ambiente construído: a abordagem dinâmica aplicada ao conforto humano. 1997. 316p. Tese (Doutorado em Ciências com ênfase em Geografia) - Faculdade de Filosofia, Letras e Ciências Humanas, Universidade de São Paulo, São Paulo.

YAMASHITA, S.; IMAMURA, I.R.; MONTEIRO, C.A.F. (1988). Observation of heat island in Patos and Campina Grande, Northest Brazil, Latin American Studies, v. 10, 145-156. 
Anexos 


\section{ANEXO A - BOLETIM CLIMANÁLISE, FEVEREIRO DE 2005}

\section{4 . PERTURBAÇÕES ATMOSFÉRI CAS SOBRE O BRASI L}

\section{3 .1 Sistemas Frontais e Frontogênese}

Em fevereiro, cinco sistemas frontais atuaram no País (Figura 22), sendo a climatologia igual a seis sistemas para latitudes entre 35 오 e $25 S$. As frentes frias foram de fraca intensidade e tiveram um rápido deslocamento pela Região Sul, causando nebulosidade e chuva fraca, principalmente no litoral desta Região. Estas chuvas ainda não foram suficientes para amenizar a estiagem prolongada observada na Região Sul nos dois últimos meses. A maior atividade dos sistemas frontais foi notada no norte de Minas Gerais, no Espírito Santo e no litoral da Bahia, onde choveu acima da média histórica.

O primeiro sistema frontal ingressou pelo sul do País no dia 01, com fraca intensidade. Esta frente fria deslocou-se pelo interior da Região Sul e pelo litoral, desde o sul do País até Salvador-BA. Ressalta-se que no dia 02, um sistema de baixa pressão que se encontrava no litoral de São Paulo interagiu com esta frente fria e ambos deslocaramse pelo litoral, posicionando-se na altura do litoral da Bahia nos dias 08 e 09.

No dia 10, o segundo sistema frontal ingressou pelo oeste e pelo litoral do Rio Grande do Sul. Esta frente fria estava associada a um sistema de baixa pressão em superfície e teve um rápido deslocamento pelo litoral das Regiões Sul e Sudeste. No dia 13, o ramo frio do sistema frontal deslocou-se para o oceano e o sistema de baixa pressão a ele associado permaneceu próximo ao litoral de São Paulo, no período de 14 a 16.

No dia 17, um sistema frontal de fraca intensidade, o terceiro do mês, avançou pelo interior e litoral do Rio Grande do Sul. Pelo litoral, deslocou-se até o sul da Bahia, indo para o oceano no dia 23.

O quarto sistema frontal estava sobre o oceano e interagiu com um cavado que se encontrava no litoral de São Paulo, reorganizando-se e deslocando-se para Santos$\mathrm{SP}$, onde enfraqueceu.

O quinto e último sistema frontal iniciou sua trajetória pelo oceano no dia 25 , encontrandose no litoral do Paraná no dia seguinte. Esta frente fria deslocou-se rapidamente pelo Sul e Sudeste do País, posicionando-se no litoral de Cabo Frio - RJ no dia 28. 
ANEXO B - ESCALA DE BEAUFORD

\begin{tabular}{|c|c|c|c|c|}
\hline \multirow{2}{*}{ Grau } & \multirow{2}{*}{ Classificação } & \multicolumn{2}{|c|}{ Velocidade do ar } & \multirow{2}{*}{ Influência em terra } \\
\hline & & $\mathrm{Km} / \mathrm{h}$ & $\mathrm{m} / \mathrm{s}$ & \\
\hline 0 & Calmaria & $0-1$ & $0-0,5$ & $\begin{array}{l}\text { A fumaça sobe } \\
\text { verticalmente. }\end{array}$ \\
\hline 1 & Aragem & $2-6$ & $0,6-1,7$ & $\begin{array}{c}\text { A direção da aragem é } \\
\text { indicada pela fumaça, } \\
\text { mas a grimpa ainda } \\
\text { não reage. }\end{array}$ \\
\hline 2 & Brisa leve & $7-12$ & $1,8-3,3$ & $\begin{array}{l}\text { Sente-se o vento no } \\
\text { rosto, movem-se as } \\
\text { folhas das árvores e a } \\
\text { grimpa começa a } \\
\text { funcionar. }\end{array}$ \\
\hline 3 & Brisa fraca & $13-18$ & $3,4-5,2$ & $\begin{array}{l}\text { As folhas das árvores } \\
\text { se agitam e as } \\
\text { bandeiras se } \\
\text { desfraldam. }\end{array}$ \\
\hline 4 & Brisa moderada & $19-26$ & $5,3-7,4$ & $\begin{array}{l}\text { Poeira e pequenos } \\
\text { papéis soltos são } \\
\text { levantados. Movem-se } \\
\text { os galhos das árvores. }\end{array}$ \\
\hline 5 & Brisa forte & $27-35$ & $7,3-9,8$ & $\begin{array}{c}\text { Movem-se as } \\
\text { pequenas árvores. Nos } \\
\text { a água começa a } \\
\text { ondular. }\end{array}$ \\
\hline 6 & Vento fresco & $36-44$ & $9,9-12,4$ & $\begin{array}{l}\text { Assobios na fiação } \\
\text { aérea. Movem-se os } \\
\text { maiores galhos das } \\
\text { árvores. Guarda-chuva } \\
\text { usado com dificuldade. }\end{array}$ \\
\hline 7 & Vento forte & $45-54$ & $12,5-15,2$ & $\begin{array}{l}\text { Movem-se as grandes } \\
\text { árvores. É difícil andar } \\
\text { contra o vento. }\end{array}$ \\
\hline 8 & Ventania & $55-65$ & $15,3-18,2$ & $\begin{array}{l}\text { Quebram-se os galhos } \\
\text { das árvores. É difícil } \\
\text { andar contra o vento. }\end{array}$ \\
\hline 9 & Ventania forte & $66-77$ & $18,3-21,5$ & $\begin{array}{c}\text { Danos nas partes } \\
\text { salientes das árvores. } \\
\text { Impossível andar contra } \\
\text { o vento. }\end{array}$ \\
\hline 10 & Tempestade & 78-90 & $21,6-25,1$ & $\begin{array}{l}\text { Arranca árvores e } \\
\text { causa danos na } \\
\text { estrutura dos prédios. }\end{array}$ \\
\hline 11 & Tempestade violenta & $90-104$ & $25,2-29,9$ & $\begin{array}{c}\text { Muito raramente } \\
\text { observado em terra. }\end{array}$ \\
\hline 12 & Furacão & $>105$ & $>30$ & Grandes estragos. \\
\hline
\end{tabular}


Apêndices 


\section{APÊNDICE A - DIFERENÇA DE TEMPERATURA ENTRE AS ESTAÇÕES CLIMÁTICAS NO DIA 20/02/2005.}

\begin{tabular}{|c|c|c|c|c|c|c|c|c|c|c|c|c|c|}
\hline dia & hora & $\begin{array}{l}\bar{U} \\
\text { ú }\end{array}$ & $\frac{5}{\frac{1}{d}}$ & U. & 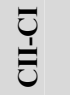 & 章 & $\stackrel{0}{\tilde{U}}$ & $\underset{I}{\beth}$ & $\underset{I}{\bar{I}}$ & 敦 & $\underset{\text { Ḋ }}{\tilde{b}}$ & 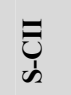 & 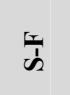 \\
\hline $20 / 2$ & 30 & $-0,6$ & $-1,2$ & $-0,2$ & 0,6 & $-0,6$ & 0,4 & 1,2 & 0,6 & 1,0 & 0,2 & $-0,4$ & $-1,0$ \\
\hline $20 / 2$ & 100 & $-0,5$ & $\begin{array}{r}1, L \\
-1,1\end{array}$ & 0,0 & 0,5 & $-0,6$ & 0,5 & 1,1 & 0,6 & 1,1 & 0,0 & $-0,5$ & $-1,1$ \\
\hline $20 / 2$ & 130 & $-0,4$ & $-1,0$ & $-0,1$ & 0,4 & $-0,6$ & 0,3 & 1,0 & 0,6 & 0,9 & 0,1 & $-0,3$ & $-0,9$ \\
\hline $20 / 2$ & 200 & $-0,5$ & $-1,0$ & 0,2 & 0,5 & $-0,5$ & 0,6 & 1,0 & 0,5 & 1,1 & $-0,2$ & $-0,6$ & $-1,1$ \\
\hline $20 / 2$ & 230 & $-0,7$ & $-1,1$ & $-0,2$ & 0,7 & $-0,4$ & 0,5 & 1,1 & 0,4 & 0,9 & 0,2 & $-0,5$ & $-0,9$ \\
\hline $20 / 2$ & 300 & $-1,1$ & $-1,1$ & 0,1 & 1,1 & 0,0 & 1,2 & 1,1 & 0,0 & 1,2 & $-0,1$ & $-1,2$ & $-1,2$ \\
\hline $20 / 2$ & 330 & $-1,2$ & $-1,1$ & 0,3 & 1,2 & 0,1 & 1,6 & 1,1 & $-0,1$ & 1,4 & $-0,3$ & $-1,6$ & $-1,4$ \\
\hline $20 / 2$ & 400 & $-1,1$ & $-0,3$ & 0,4 & 1,1 & 0,8 & 1,5 & 0,3 & $-0,8$ & 0,7 & $-0,4$ & $-1,5$ & $-0,7$ \\
\hline $20 / 2$ & 430 & $-0,9$ & $-0,6$ & 0,5 & 0,9 & 0,4 & 1,4 & 0,6 & $-0,4$ & 1,1 & $-0,5$ & $-1,4$ & $-1,1$ \\
\hline $20 / 2$ & 500 & $-1,2$ & $-0,8$ & 0,4 & 1,2 & 0,5 & 1,6 & 0,8 & $-0,5$ & 1,2 & $-0,4$ & $-1,6$ & $-1,2$ \\
\hline $20 / 2$ & 530 & $-1,0$ & $-0,8$ & 0,2 & 1,0 & 0,2 & 1,1 & 0,8 & $-0,2$ & 0,9 & $-0,2$ & $-1,1$ & $-0,9$ \\
\hline $20 / 2$ & 600 & $-0,9$ & $-0,9$ & $-0,1$ & 0,9 & 0,0 & 0,8 & 0,9 & 0,0 & 0,8 & 0,1 & $-0,8$ & $-0,8$ \\
\hline $20 / 2$ & 630 & $-1,1$ & $-1,1$ & $-0,3$ & 1,1 & 0,0 & 0,8 & 1,1 & 0,0 & 0,8 & 0,3 & $-0,8$ & $-0,8$ \\
\hline $20 / 2$ & 700 & $-0,7$ & $-0,9$ & 0,0 & 0,7 & $-0,1$ & 0,7 & 0,9 & 0,1 & 0,9 & 0,0 & $-0,7$ & $-0,9$ \\
\hline $20 / 2$ & 730 & 0,6 & $-0,4$ & 0,2 & $-0,6$ & $-1,0$ & $-0,4$ & 0,4 & 1,0 & 0,6 & $-0,2$ & 0,4 & $-0,6$ \\
\hline $20 / 2$ & 800 & 0,3 & $-0,4$ & $-0,8$ & $-0,3$ & $-0,7$ & $-1,1$ & 0,4 & 0,7 & $-0,5$ & 0,8 & 1,1 & 0,5 \\
\hline $20 / 2$ & 830 & $-0,4$ & $-1,4$ & $-2,0$ & 0,4 & $-1,0$ & $-1,6$ & 1,4 & 1,0 & $-0,6$ & 2,0 & 1,6 & 0,6 \\
\hline $20 / 2$ & 900 & $-0,8$ & $-1,6$ & $-1,8$ & 0,8 & $-0,7$ & $-1,0$ & 1,6 & 0,7 & $-0,3$ & 1,8 & 1,0 & 0,3 \\
\hline $20 / 2$ & 930 & $-0,8$ & $-1,8$ & $-1,9$ & 0,8 & $-1,0$ & $-1,1$ & 1,8 & 1,0 & $-0,1$ & 1,9 & 1,1 & 0,1 \\
\hline $20 / 2$ & 1000 & $-0,3$ & $-1,3$ & $-1,7$ & 0,3 & $-1,1$ & $-1,4$ & 1,3 & 1,1 & $-0,3$ & 1,7 & 1,4 & 0,3 \\
\hline $20 / 2$ & 1030 & 0,3 & $-1,2$ & $-1,5$ & $-0,3$ & $-1,4$ & $-1,7$ & 1,2 & 1,4 & $-0,3$ & 1,5 & 1,7 & 0,3 \\
\hline $20 / 2$ & 1100 & $-0,2$ & $-1,7$ & $-1,8$ & 0,2 & $-1,5$ & $-1,6$ & 1,7 & 1,5 & $-0,1$ & 1,8 & 1,6 & 0,1 \\
\hline $20 / 2$ & 1130 & 0,1 & $-1,4$ & $-1,6$ & $-0,1$ & $-1,5$ & $-1,7$ & 1,4 & 1,5 & $-0,3$ & 1,6 & 1,7 & 0,3 \\
\hline $20 / 2$ & 1200 & 0,2 & $-1,6$ & $-1,2$ & $-0,2$ & $-1,8$ & $-1,4$ & 1,6 & 1,8 & 0,4 & 1,2 & 1,4 & $-0,4$ \\
\hline $20 / 2$ & 1230 & 0,0 & $-1,5$ & $-1,4$ & 0,0 & $-1,5$ & $-1,5$ & 1,5 & 1,5 & 0,1 & 1,4 & 1,5 & $-0,1$ \\
\hline $20 / 2$ & 1300 & 0,0 & $\begin{array}{r}-1,1 \\
-1,1\end{array}$ & $-1,2$ & 0,0 & $\begin{array}{r}-1,0 \\
-1,0\end{array}$ & $\begin{array}{r}1,2 \\
-1,2\end{array}$ & 1,1 & 1,0 & $-0,2$ & 1,2 & 1,2 & 0,2 \\
\hline $20 / 2$ & 1330 & 0,0 & $-1,4$ & $-1,3$ & 0,0 & $-1,4$ & $-1,3$ & 1,4 & 1,4 & 0,1 & 1,3 & 1,3 & $-0,1$ \\
\hline $20 / 2$ & 1400 & & $-1,5$ & $-1,5$ & & & & 1,5 & & 0,0 & 1,5 & & 0,0 \\
\hline $20 / 2$ & 1430 & & $\begin{array}{r}-1,7 \\
-\end{array}$ & $-1,3$ & & & & 1,7 & & 0,4 & 1,3 & & $-0,4$ \\
\hline $20 / 2$ & 1500 & & $-2,2$ & $-1,7$ & & & & 2,2 & & 0,4 & 1,7 & & $-0,4$ \\
\hline $20 / 2$ & 1530 & & $-2,3$ & $-1,6$ & & & & 2,3 & & 0,7 & 1,6 & & $-0,7$ \\
\hline $20 / 2$ & 1600 & & $-1,6$ & $-1,5$ & & & & 1,6 & & 0,1 & 1,5 & & $-0,1$ \\
\hline $20 / 2$ & 1630 & & $-1,1$ & $-1,4$ & & & & 1,1 & & $-0,3$ & 1,4 & & 0,3 \\
\hline $20 / 2$ & 1700 & & $-1,2$ & $-1,4$ & & & & 1,2 & & $-0,2$ & 1,4 & & 0,2 \\
\hline $20 / 2$ & 1730 & & $-1,3$ & $-1,3$ & & & & 1,3 & & 0,0 & 1,3 & & 0,0 \\
\hline $20 / 2$ & 1800 & & $-1,4$ & $-1,2$ & & & & 1,4 & & 0,2 & 1,2 & & $-0,2$ \\
\hline $20 / 2$ & 1830 & & $-1,5$ & $-1,2$ & & & & 1,5 & & 0,3 & 1,2 & & $-0,3$ \\
\hline $20 / 2$ & 1900 & & $-1,7$ & $-0,8$ & & & & 1,7 & & 0,9 & 0,8 & & $-0,9$ \\
\hline $20 / 2$ & 1930 & & $-2,5$ & $-0,6$ & & & & 2,5 & & 1,9 & 0,6 & & $-1,9$ \\
\hline $20 / 2$ & 2000 & & $-2,8$ & $-0,6$ & & & & 2,8 & & 2,2 & 0,6 & & $-2,2$ \\
\hline $20 / 2$ & 2030 & & $-3,2$ & $-0,6$ & & & & 3,2 & & 2,6 & 0,6 & & $-2,6$ \\
\hline $20 / 2$ & 2100 & & $-2,4$ & $-0,6$ & & & & 2,4 & & 1,8 & 0,6 & & $-1,8$ \\
\hline $20 / 2$ & 2130 & & $-1,5$ & $-0,6$ & & & & 1,5 & & 0,9 & 0,6 & & $-0,9$ \\
\hline $20 / 2$ & 2200 & & $-1,2$ & $-0,5$ & & & & 1,2 & & 0,7 & 0,5 & & $-0,7$ \\
\hline $20 / 2$ & 2230 & & $-1,5$ & $-0,5$ & & & & 1,5 & & 1,0 & 0,5 & & $-1,0$ \\
\hline $20 / 2$ & 2300 & & $-1,5$ & $-0,5$ & & & & 1,5 & & 1,0 & 0,5 & & $-1,0$ \\
\hline $20 / 2$ & 2330 & & $\begin{array}{r}1,0 \\
-1,5\end{array}$ & $-0,5$ & & & & 1,5 & & 1,1 & 0,5 & & $\begin{array}{r}1,0 \\
-1,1\end{array}$ \\
\hline $20 / 2$ & 2400 & & $-1,5$ & $-0,5$ & & & & 1,5 & & 1,0 & 0,5 & & $-1,0$ \\
\hline
\end{tabular}

Legenda: CI - Campus I; CII - Campus II; F - Fadisc; S - Samambaia 


\section{APÊNDICE B - DIFERENÇA DE TEMPERATURA ENTRE AS ESTAÇÕES CLIMÁTICAS NO DIA 21/02/2005.}

\begin{tabular}{|c|c|c|c|c|c|c|c|c|c|c|c|c|c|}
\hline dia & hora & $\begin{array}{l}\bar{E} \\
\text { ú }\end{array}$ & $\frac{\pi}{U}$ & $\frac{0}{0}$ & $\begin{array}{l}\bar{J} \\
\bar{J}\end{array}$ & 章 & $\stackrel{0}{\tilde{E}}$ & 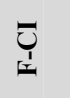 & 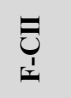 & I & $\begin{array}{l}\bar{y} \\
\text { Dh }\end{array}$ & ర్ & 战 \\
\hline $21 / 2$ & 30 & & $-1,6$ & $-0,5$ & & & & 1,6 & & 1,1 & 0,5 & & $-1,1$ \\
\hline $21 / 2$ & 100 & & $-1,6$ & $-0,6$ & & & & 1,6 & & 0,9 & 0,6 & & $-0,9$ \\
\hline $21 / 2$ & 130 & & $-1,6$ & $-0,6$ & & & & 1,6 & & 1,0 & 0,6 & & $-1,0$ \\
\hline $21 / 2$ & 200 & $-0,3$ & $-1,5$ & $-0,5$ & 0,3 & $-1,2$ & $-0,2$ & 1,5 & 1,2 & 1,0 & 0,5 & 0,2 & $-1,0$ \\
\hline $21 / 2$ & 230 & $-0,2$ & $-1,4$ & $-0,6$ & 0,2 & $-1,3$ & $-0,4$ & 1,4 & 1,3 & 0,8 & 0,6 & 0,4 & $-0,8$ \\
\hline $21 / 2$ & 300 & $-0,3$ & $-1,2$ & $-0,6$ & 0,3 & $-0,9$ & $-0,3$ & 1,2 & 0,9 & 0,6 & 0,6 & 0,3 & $-0,6$ \\
\hline $21 / 2$ & 330 & $-0,4$ & $-1,0$ & $-0,5$ & 0,4 & $-0,6$ & $-0,1$ & 1,0 & 0,6 & 0,5 & 0,5 & 0,1 & $-0,5$ \\
\hline $21 / 2$ & 400 & $-0,4$ & $-1,5$ & $-0,5$ & 0,4 & $-1,0$ & $-0,1$ & 1,5 & 1,0 & 1,0 & 0,5 & 0,1 & $-1,0$ \\
\hline $21 / 2$ & 430 & $-0,4$ & $-1,4$ & $-0,5$ & 0,4 & $-0,9$ & 0,0 & 1,4 & 0,9 & 0,9 & 0,5 & 0,0 & $-0,9$ \\
\hline $21 / 2$ & 500 & $-0,2$ & $-1,4$ & $-0,6$ & 0,2 & $-1,2$ & $-0,3$ & 1,4 & 1,2 & 0,9 & 0,6 & 0,3 & $-0,9$ \\
\hline $21 / 2$ & 530 & $-0,1$ & $-1,6$ & $-0,6$ & 0,1 & $-1,5$ & $-0,4$ & 1,6 & 1,5 & 1,0 & 0,6 & 0,4 & $-1,0$ \\
\hline $21 / 2$ & 600 & $-0,1$ & $-1,4$ & $-0,6$ & 0,1 & $-1,3$ & $-0,5$ & 1,4 & 1,3 & 0,8 & 0,6 & 0,5 & $-0,8$ \\
\hline $21 / 2$ & 630 & $-0,5$ & $-1,4$ & $-0,5$ & 0,5 & $-0,9$ & 0,0 & 1,4 & 0,9 & 0,9 & 0,5 & 0,0 & $-0,9$ \\
\hline $21 / 2$ & 700 & $-0,7$ & $-1,2$ & $-0,4$ & 0,7 & $-0,5$ & 0,3 & 1,2 & 0,5 & 0,8 & 0,4 & $-0,3$ & $-0,8$ \\
\hline $21 / 2$ & 730 & $-0,4$ & $-0,7$ & $-1,0$ & 0,4 & $-0,3$ & $-0,6$ & 0,7 & 0,3 & $-0,3$ & 1,0 & 0,6 & 0,3 \\
\hline $21 / 2$ & 800 & $-1,5$ & $-1,7$ & $-2,1$ & 1,5 & $-0,3$ & $-0,6$ & 1,7 & 0,3 & $-0,4$ & 2,1 & 0,6 & 0,4 \\
\hline $21 / 2$ & 830 & $-1,7$ & $-1,9$ & $-2,0$ & 1,7 & $-0,2$ & $-0,3$ & 1,9 & 0,2 & $-0,1$ & 2,0 & 0,3 & 0,1 \\
\hline $21 / 2$ & 900 & $-1,4$ & $-1,1$ & $-1,9$ & 1,4 & 0,3 & $-0,5$ & 1,1 & $-0,3$ & $-0,7$ & 1,9 & 0,5 & 0,7 \\
\hline $21 / 2$ & 930 & $-1,6$ & $-1,4$ & $\begin{array}{l}-1,7 \\
\end{array}$ & 1,6 & 0,2 & 0,0 & 1,4 & $-0,2$ & $-0,2$ & 1,7 & 0,0 & 0,2 \\
\hline $21 / 2$ & 1000 & $-2,0$ & $-2,0$ & $-1,7$ & 2,0 & 0,0 & 0,2 & 2,0 & 0,0 & 0,2 & 1,7 & $-0,2$ & $-0,2$ \\
\hline $21 / 2$ & 1030 & $-1,2$ & $-2,0$ & $-1,7$ & 1,2 & $-0,8$ & $-0,5$ & 2,0 & 0,8 & 0,3 & 1,7 & 0,5 & $-0,3$ \\
\hline $21 / 2$ & 110 & $-0,6$ & $-1,7$ & $-1,2$ & 0,6 & $-1,1$ & $-0,6$ & 1,7 & 1,1 & 0,5 & 1,2 & 0,6 & $-0,5$ \\
\hline $21 / 2$ & 1130 & $-0,5$ & $-1,9$ & $-1,3$ & 0,5 & $-1,4$ & $-0,8$ & 1,9 & 1,4 & 0,6 & 1,3 & 0,8 & $-0,6$ \\
\hline $21 / 2$ & 1200 & $-0,4$ & $-1,6$ & $-1,1$ & 0,4 & $-1,2$ & $-0,7$ & 1, & 1,2 & 0,5 & 1,1 & 0,7 & $-0,5$ \\
\hline $21 / 2$ & 1230 & $-0,3$ & $-1,5$ & $-1,2$ & 0,3 & $-1,2$ & $-0,9$ & 1,5 & 1,2 & 0,3 & 1,2 & 0,9 & $-0,3$ \\
\hline $21 / 2$ & 1300 & $-0,6$ & $-1,7$ & $-1,3$ & 0,6 & $-1,1$ & $-0,8$ & 1,7 & 1,1 & 0,3 & 1,3 & 0,8 & $-0,3$ \\
\hline $21 / 2$ & 1330 & $-0,3$ & $-1,9$ & $-1,5$ & 0,3 & $-1,5$ & $-1,1$ & 1, & 1,5 & 0,4 & 1,5 & 1,1 & $-0,4$ \\
\hline $21 / 2$ & 140 & $-0,8$ & $-2,1$ & -1 & 0,8 & $-1,3$ & $-1,0$ & 2, & 1,3 & 0,2 & 1, & 1,0 & $-0,2$ \\
\hline $21 / 2$ & 1430 & $-0,7$ & $-1,8$ & $-1,3$ & 0,7 & $-1,2$ & $-0,7$ & 1,8 & 1,2 & 0,5 & 1,3 & 0,7 & $-0,5$ \\
\hline $21 / 2$ & 1500 & $-0,7$ & $-1,5$ & $-1,5$ & 0,7 & $-0,8$ & $-0,8$ & 1,5 & 0,8 & 0,1 & 1,5 & 0,8 & $-0,1$ \\
\hline $21 / 2$ & 1530 & $-0,6$ & $-1,6$ & $-1,6$ & 0,6 & $-0,9$ & $-1,0$ & 1,6 & 0,9 & 0,0 & 1,6 & 1,0 & 0,0 \\
\hline $21 / 2$ & 1600 & $-1,1$ & $-1,6$ & $-1,5$ & 1,1 & $-0,6$ & $-0,5$ & 1,6 & 0,6 & 0,1 & 1,5 & 0,5 & $-0,1$ \\
\hline $21 / 2$ & 16 & $-0,7$ & $-1,8$ & $-1,6$ & 0,7 & $-1,1$ & $-0,9$ & 1, & 1,1 & 0,2 & 1,6 & 0,9 & $-0,2$ \\
\hline $21 / 2$ & 1700 & $-0,3$ & 113 & $-1,3$ & 0,3 & $-1,0$ & $-1,1$ & 1 & 1,0 & $-0,1$ & 1,3 & 1,1 & 0,1 \\
\hline $21 / 2$ & 1730 & $-0,1$ & $-1,4$ & $-1,3$ & 0,1 & $-1,3$ & $-1,2$ & 1,4 & 1,3 & 0,1 & 1,3 & 1,2 & $-0,1$ \\
\hline $21 / 2$ & 1800 & $-0,4$ & $-1,4$ & $-1,3$ & 0,4 & $-0,9$ & $-0,9$ & 1,4 & 0,9 & 0,0 & 1,3 & 0,9 & 0,0 \\
\hline $21 / 2$ & 1830 & $-0,1$ & $-1,6$ & $-0,9$ & 0,1 & $-1,5$ & $-0,8$ & 1,6 & 1,5 & 0,7 & 0,9 & 0,8 & $-0,7$ \\
\hline $21 / 2$ & 1900 & $-0,4$ & $-2,4$ & -0, & 0,4 & $-2,0$ & $-0,2$ & 2,4 & 2,0 & 1,8 & 0,6 & 0,2 & $-1,8$ \\
\hline $21 / 2$ & 19 & $-1,3$ & $-2,2$ & -0 , & 1,3 & $-0,8$ & 0,9 & 2,2 & 0, & 8 & 0,4 & $-0,9$ & $-1,8$ \\
\hline $21 / 2$ & 2000 & $-2,1$ & -23 & $-0,5$ & 2,1 & $-0,2$ & 1,6 & 2,3 & 02 & 1,8 & 0,5 & $-1,6$ & $-1,8$ \\
\hline $21 / 2$ & 2030 & $-2,9$ & $-2,5$ & $-0,4$ & 2,9 & 0,4 & 2,5 & 2,5 & $-0,4$ & 2,1 & 0,4 & $-2,5$ & $-2,1$ \\
\hline $21 / 2$ & 2100 & $-2,6$ & $-2,6$ & $-0,4$ & 2,6 & $-0,1$ & 2,2 & 2,6 & 0,1 & 2,3 & 0,4 & $-2,2$ & $-2,3$ \\
\hline $21 / 2$ & 2130 & $-2,7$ & $-1,8$ & $-0,3$ & 2,7 & 0,8 & 2,4 & 1,8 & $-0,8$ & 1,6 & 0,3 & $-2,4$ & $-1,6$ \\
\hline $21 / 2$ & 2200 & $-2,7$ & $-1,9$ & $-0,3$ & 2,7 & 0,8 & 2,4 & 1,9 & $-0,8$ & 1,6 & 0,3 & $-2,4$ & $-1,6$ \\
\hline $21 / 2$ & 2230 & $-2,0$ & $-1,9$ & $-0,3$ & 2,0 & 0,1 & 1,7 & 1,9 & $-0,1$ & 1,6 & 0,3 & $-1,7$ & $-1,6$ \\
\hline $21 / 2$ & & $-1,0$ & -1 & $-0,2$ & 1, & $-0,7$ & 0,8 & 1,7 & 0 , & 1,5 & 0,2 & $-0,8$ & $-1,5$ \\
\hline $21 / 2$ & 2330 & $-0,5$ & $-1,4$ & $-0,4$ & 0,5 & $-1,0$ & 0,0 & 1,4 & 1,0 & 1,0 & 0,4 & 0,0 & $-1,0$ \\
\hline $21 / 2$ & 2400 & $-0,9$ & $-1,6$ & $-0,6$ & 0,9 & $-0,8$ & 0,3 & 1,6 & 0,8 & 1,0 & 0,6 & $-0,3$ & $-1,0$ \\
\hline
\end{tabular}

Legenda: CI - Campus I; CII - Campus II; F - Fadisc; S - Samambaia 


\section{APÊNDICE C - DIFERENÇA DE TEMPERATURA ENTRE AS ESTAÇÕES CLIMÁTICAS NO DIA 22/02/2005.}

\begin{tabular}{|c|c|c|c|c|c|c|c|c|c|c|c|c|c|}
\hline dia & hora & $\begin{array}{l}\bar{Z} \\
\text { U }\end{array}$ & $\frac{5}{1}$ & Uి & تِ & $\stackrel{5}{\frac{5}{3}}$ & $\stackrel{0}{\tilde{U}}$ & 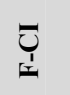 & $\underset{I}{\Xi}$ & 敦 & 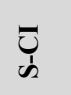 & 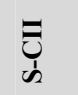 & 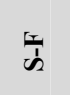 \\
\hline $22 / 2$ & 30 & 0,5 & $-1,0$ & 0,3 & $-0,5$ & $-1,5$ & $-0,2$ & 1,0 & 1,5 & 1,3 & $-0,3$ & 0,2 & $-1,3$ \\
\hline $22 / 2$ & 100 & 1,1 & 0,2 & 0,2 & $-1,1$ & $-0,8$ & $-0,9$ & $-0,2$ & 0,8 & 0,0 & $-0,2$ & 0,9 & 0,0 \\
\hline $22 / 2$ & 130 & 0,9 & 0,1 & 0,0 & $-0,9$ & $-0,8$ & $-1,0$ & $-0,1$ & 0,8 & $-0,1$ & 0,0 & 1,0 & 0,1 \\
\hline $22 / 2$ & 200 & $-0,3$ & $-0,1$ & 0,4 & 0,3 & 0,2 & 0,7 & 0,1 & $-0,2$ & 0,5 & $-0,4$ & $-0,7$ & $-0,5$ \\
\hline $22 / 2$ & 230 & $-0,3$ & $-0,4$ & 1,1 & 0,3 & $-0,1$ & 1,4 & 0,4 & 0,1 & 1,5 & $-1,1$ & $-1,4$ & $-1,5$ \\
\hline $22 / 2$ & 300 & $-0,4$ & $-0,5$ & 1,5 & 0,4 & $-0,2$ & 1,9 & 0,5 & 0,2 & 2,1 & $-1,5$ & $-1,9$ & $-2,1$ \\
\hline $22 / 2$ & 330 & 1,1 & 0,5 & 1,5 & $-1,1$ & $-0,6$ & 0,3 & $-0,5$ & 0,6 & 1,0 & $-1,5$ & $-0,3$ & $-1,0$ \\
\hline $22 / 2$ & 400 & 0,5 & 0,3 & 1,4 & $-0,5$ & $-0,3$ & 0,9 & $-0,3$ & 0,3 & 1,2 & $-1,4$ & $-0,9$ & $-1,2$ \\
\hline $22 / 2$ & 430 & 0,8 & 1,0 & 2,2 & $-0,8$ & 0,1 & 1,3 & $-1,0$ & $-0,1$ & 1,2 & $-2,2$ & $-1,3$ & $-1,2$ \\
\hline $22 / 2$ & 500 & $-0,4$ & 1,7 & 1,5 & 0,4 & 2,1 & 1,9 & $-1,7$ & $-2,1$ & $-0,1$ & $-1,5$ & $-1,9$ & 0,1 \\
\hline $22 / 2$ & 530 & $-0,9$ & 2,5 & 1,5 & 0,9 & 3,3 & 2,4 & $-2,5$ & $-3,3$ & $-1,0$ & $-1,5$ & $-2,4$ & 1,0 \\
\hline $22 / 2$ & 600 & $-1,0$ & 2,3 & 1,7 & 1,0 & 3,2 & 2,6 & $-2,3$ & $-3,2$ & $-0,6$ & $-1,7$ & $-2,6$ & 0,6 \\
\hline $22 / 2$ & 630 & $-1,2$ & 2,4 & 2,5 & 1,2 & 3,6 & 3,7 & $-2,4$ & $-3,6$ & 0,1 & $-2,5$ & $-3,7$ & $-0,1$ \\
\hline $22 / 2$ & 700 & $-1,7$ & 2,8 & 3,2 & 1,7 & 4,5 & 4,9 & $-2,8$ & $-4,5$ & 0,4 & $-3,2$ & $-4,9$ & $-0,4$ \\
\hline $22 / 2$ & 730 & $-1,2$ & 1,9 & 1,6 & 1,2 & 3,1 & 2,8 & $-1,9$ & $-3,1$ & $-0,3$ & $-1,6$ & $-2,8$ & 0,3 \\
\hline $22 / 2$ & 800 & $-1,4$ & $-0,8$ & $-1,5$ & 1,4 & 0,6 & $-0,2$ & 0,8 & $-0,6$ & $-0,7$ & 1,5 & 0,2 & 0,7 \\
\hline $22 / 2$ & 830 & $-1,1$ & $-1,3$ & $-1,4$ & 1,1 & $-0,1$ & $-0,3$ & 1,3 & 0,1 & $-0,1$ & 1,4 & 0,3 & 0,1 \\
\hline $22 / 2$ & 900 & $-0,9$ & $-1,7$ & $-1,4$ & 0,9 & $-0,8$ & $-0,5$ & 1,7 & 0,8 & 0,3 & 1,4 & 0,5 & $-0,3$ \\
\hline $22 / 2$ & 930 & $-0,9$ & $-1,9$ & $-1,6$ & 0,9 & $-1,0$ & $-0,7$ & 1,9 & 1,0 & 0,3 & 1,6 & 0,7 & $-0,3$ \\
\hline $22 / 2$ & 1000 & $-0,8$ & $-2,1$ & $-1,7$ & 0,8 & $-1,3$ & $-0,8$ & 2,1 & 1,3 & 0,4 & 1,7 & 0,8 & $-0,4$ \\
\hline $22 / 2$ & 103 & $-0,8$ & $-2,4$ & $-1,9$ & 0,8 & $-1,6$ & $-1,1$ & 2,4 & 1,6 & 0,5 & 1,9 & 1,1 & $-0,5$ \\
\hline $22 / 2$ & 110 & $-0,3$ & $-1,7$ & $-1,2$ & 0,3 & $-1,4$ & $-0,9$ & 1,7 & 1,2 & 0,5 & 1,2 & 0,9 & $-0,5$ \\
\hline $22 / 2$ & 1130 & $-0,5$ & $-1,6$ & $-1,2$ & 0,5 & $-1,1$ & $-0,7$ & 1,6 & 1,1 & 0,4 & 1,2 & 0,7 & $-0,4$ \\
\hline $22 / 2$ & 1200 & $-0,2$ & $-1,0$ & $-0,5$ & 0,2 & $-0,8$ & $-0,2$ & 1,0 & 0,8 & 0,5 & 0,5 & 0,2 & $-0,5$ \\
\hline $22 / 2$ & 1230 & $-0,2$ & $-1,1$ & $-0,9$ & 0,2 & $-1,0$ & $-0,8$ & 1,1 & 1,0 & 0,2 & 0,9 & 0,8 & $-0,2$ \\
\hline $22 / 2$ & 130 & $-0,4$ & $-1,4$ & $-1,2$ & 0,4 & $-1,0$ & $-0,8$ & 1,4 & 1,0 & 0,2 & 1,2 & 0,8 & $-0,2$ \\
\hline $22 / 2$ & 133 & $-0,4$ & $-1,5$ & $-1,2$ & 0,4 & $-1,1$ & $-0,8$ & 1,5 & 1,1 & 0,3 & 1,2 & 0,8 & $-0,3$ \\
\hline $22 / 2$ & 1400 & $-0,2$ & $-1,3$ & $-1,4$ & 0,2 & $-1,0$ & $-1,2$ & 1,3 & 1,0 & $-0,1$ & 1,4 & 1,2 & 0,1 \\
\hline $22 / 2$ & 1430 & $-0,2$ & $-1,1$ & $-1,2$ & 0,2 & $-1,0$ & $-1,0$ & 1,1 & 1,0 & 0,0 & 1,2 & 1,0 & 0,0 \\
\hline $22 / 2$ & 1500 & $-0,3$ & $-1,5$ & $-1,3$ & 0,3 & $-1,2$ & $-1,0$ & 1, & 1,2 & 0,2 & 1,3 & 1,0 & $-0,2$ \\
\hline $22 / 2$ & 153 & $-0,8$ & $-2,2$ & $-1,9$ & 0,8 & $-1,4$ & $-1,1$ & 2,2 & 1,4 & 0,3 & 1,9 & 1,1 & $-0,3$ \\
\hline $22 / 2$ & 1600 & 0,1 & $-1,2$ & $-1,0$ & $-0,1$ & $-1,3$ & $-1,1$ & 1,2 & 1,3 & 0,2 & 1,0 & 1,1 & $-0,2$ \\
\hline $22 / 2$ & 1630 & 0,0 & $-0,9$ & $-1,1$ & 0,0 & $-0,9$ & $-1,1$ & 0,9 & 0,9 & $-0,2$ & 1,1 & 1,1 & 0,2 \\
\hline $22 / 2$ & 1700 & $-0,2$ & $-1,0$ & $-1,4$ & 0,2 & $-0,8$ & $-1,3$ & 1,0 & 0,8 & $-0,5$ & 1,4 & 1,3 & 0,5 \\
\hline $22 / 2$ & 1730 & 0,3 & $-0,8$ & $-1,4$ & $-0,3$ & $-1,1$ & $-1,6$ & 0,8 & 1,1 & $-0,5$ & 1,4 & 1,6 & 0,5 \\
\hline $22 / 2$ & 180 & 0,6 & $-1,0$ & $-1,8$ & $-0,6$ & $-1,6$ & $-2,4$ & 1,0 & 1,6 & $-0,8$ & 1,8 & 2,4 & 0,8 \\
\hline $22 / 2$ & 183 & 0,7 & $-1,3$ & $-1,3$ & $-0,7$ & $-2,0$ & $-2,0$ & 1,3 & 2, & 0,0 & 1,3 & 2, & 0,0 \\
\hline $22 / 2$ & 190 & 0,2 & -1, & $-0,5$ & $-0,2$ & $-2,1$ & $-0,8$ & 1, & 2 & 1,3 & 0,5 & 0 & $-1,3$ \\
\hline $22 / 2$ & 1930 & $-1,0$ & $-1,6$ & $-0,1$ & 1,0 & $-0,6$ & 0,9 & 1,6 & 0,6 & 1,5 & 0,1 & $-0,9$ & $-1,5$ \\
\hline $22 / 2$ & 2000 & $-2,4$ & $-1,4$ & 0,7 & 2,4 & 1,0 & 3,1 & 1,4 & $-1,0$ & 2,1 & $-0,7$ & $-3,1$ & $-2,1$ \\
\hline $22 / 2$ & 2030 & $-2,2$ & 0,1 & 1,3 & 2,2 & 2,3 & 3,5 & $-0,1$ & $-2,3$ & 1,2 & $-1,3$ & $-3,5$ & $-1,2$ \\
\hline $22 / 2$ & 2100 & $-2,4$ & 1,1 & 1,6 & 2,4 & 3,5 & 4,0 & $-1,1$ & $-3,5$ & 0,5 & $-1,6$ & $-4,0$ & $-0,5$ \\
\hline $22 / 2$ & 2130 & $-2,1$ & 1 , & 2,2 & 2,1 & 3,1 & 4,3 & $-1,0$ & $-3,1$ & 1,1 & $-2,2$ & $-4,3$ & $-1,1$ \\
\hline $22 / 2$ & 2200 & $-2,1$ & 0 , & 2,6 & 2,1 & 2,4 & 4,7 & $-0,3$ & $-2,4$ & 2,3 & $-2,6$ & $-4,7$ & $-2,3$ \\
\hline $22 / 2$ & 2230 & $-1,9$ & 0,9 & 2,2 & 1,9 & 2,8 & 4,1 & $-0,9$ & $-2,8$ & 1,3 & $-2,2$ & $-4,1$ & $-1,3$ \\
\hline $22 / 2$ & 2300 & $-1,8$ & 1,1 & 2,5 & 1,8 & 2,9 & 4,3 & $-1,1$ & $-2,9$ & 1,4 & $-2,5$ & $-4,3$ & $-1,4$ \\
\hline $22 / 2$ & 2330 & $-1,4$ & 1,6 & 2,9 & 1,4 & 3,0 & 4,3 & $-1,6$ & $-3,0$ & 1,4 & $-2,9$ & $-4,3$ & $-1,4$ \\
\hline $22 / 2$ & 2400 & $-1,7$ & 1,4 & 2,9 & 1,7 & 3,0 & 4,5 & $-1,4$ & $-3,0$ & 1,5 & $-2,9$ & $-4,5$ & $-1,5$ \\
\hline
\end{tabular}

Legenda: CI - Campus I; CII - Campus II; F - Fadisc; S - Samambaia 


\section{APÊNDICE D - DIFERENÇA DE TEMPERATURA ENTRE AS ESTAÇÕES CLIMÁTICAS NO DIA 23/02/2005.}

\begin{tabular}{|c|c|c|c|c|c|c|c|c|c|c|c|c|c|}
\hline dia & hora & $\begin{array}{l}\bar{\Xi} \\
u\end{array}$ & $\frac{5}{1}$ & $\frac{\tilde{I}}{0}$ & 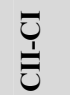 & $\stackrel{5}{\bar{J}}$ & $\stackrel{\tilde{1}}{=}$ & ગ્ & $\underset{I}{E}$ & i & $\underset{n}{\tilde{D}}$ & $\underbrace{}_{n}$ & 晸 \\
\hline $23 / 2$ & 30 & $\begin{array}{l}-1,3 \\
\end{array}$ & 1,7 & 2,9 & 1,3 & 3,1 & 4,2 & $\begin{array}{l}-1,7 \\
\end{array}$ & $-3,1$ & 1,1 & $-2,9$ & $-4,2$ & $-1,1$ \\
\hline $23 / 2$ & 100 & $-1,1$ & 2,5 & 3,1 & 1,1 & 3,6 & 4,2 & $-2,5$ & $-3,6$ & 0,6 & $-3,1$ & $-4,2$ & $-0,6$ \\
\hline $23 / 2$ & 130 & $-1,3$ & 2,9 & 2,7 & 1,3 & 4,2 & 4,0 & $-2,9$ & $-4,2$ & $-0,3$ & $-2,7$ & $-4,0$ & 0,3 \\
\hline $23 / 2$ & 200 & $-1,3$ & 2,7 & 3,2 & 1,3 & 4,0 & 4,5 & $-2,7$ & $-4,0$ & 0,5 & $-3,2$ & $-4,5$ & $-0,5$ \\
\hline $23 / 2$ & 230 & $-0,9$ & 2,6 & 3,2 & 0,9 & 3,5 & 4,2 & $-2,6$ & $-3,5$ & 0,7 & $-3,2$ & $-4,2$ & $-0,7$ \\
\hline $23 / 2$ & 300 & $-0,8$ & 2,6 & 3,8 & 0,8 & 3,4 & 4,6 & $-2,6$ & $-3,4$ & 1,1 & $-3,8$ & $-4,6$ & $-1,1$ \\
\hline $23 / 2$ & 330 & $-1,0$ & 2,9 & 3,0 & 1,0 & 3,8 & 4,0 & $-2,9$ & $-3,8$ & 0,1 & $-3,0$ & $-4,0$ & $-0,1$ \\
\hline $23 / 2$ & 400 & $-1,0$ & 3,2 & 3,2 & 1,0 & 4,2 & 4,2 & $-3,2$ & $-4,2$ & 0,0 & $-3,2$ & $-4,2$ & 0,0 \\
\hline $23 / 2$ & 430 & $-0,9$ & 3,4 & 3,2 & 0,9 & 4,3 & 4,0 & $-3,4$ & $-4,3$ & $-0,3$ & $-3,2$ & $-4,0$ & 0,3 \\
\hline $23 / 2$ & 500 & $-0,7$ & 3,5 & 3,4 & 0,7 & 4,2 & 4,1 & $-3,5$ & $-4,2$ & $-0,1$ & $-3,4$ & $-4,1$ & 0,1 \\
\hline $23 / 2$ & 530 & $-0,6$ & 3,5 & 4,4 & 0,6 & 4,1 & 5,0 & $-3,5$ & $-4,1$ & 0,9 & $-4,4$ & $-5,0$ & $-0,9$ \\
\hline $23 / 2$ & 600 & $-0,5$ & 3,7 & 4,8 & 0,5 & 4,1 & 5,2 & $-3,7$ & $-4,1$ & 1,1 & $-4,8$ & $-5,2$ & $-1,1$ \\
\hline $23 / 2$ & 630 & $-0,4$ & 4,0 & 5,1 & 0,4 & 4,4 & 5,5 & $-4,0$ & $-4,4$ & 1,1 & $-5,1$ & $-5,5$ & $-1,1$ \\
\hline $23 / 2$ & 700 & $-0,8$ & 3,9 & 4,7 & 0,8 & 4,7 & 5,5 & $-3,9$ & $-4,7$ & 0,8 & $-4,7$ & $-5,5$ & $-0,8$ \\
\hline $23 / 2$ & 730 & $-0,3$ & 3,3 & 3,3 & 0,3 & 3,6 & 3,6 & $-3,3$ & $-3,6$ & 0,1 & $-3,3$ & $-3,6$ & $-0,1$ \\
\hline $23 / 2$ & 800 & 0,4 & 0,8 & 0,1 & $-0,4$ & 0,4 & $-0,2$ & $-0,8$ & $-0,4$ & $-0,7$ & $-0,1$ & 0,2 & 0,7 \\
\hline $23 / 2$ & 830 & $-0,6$ & $-1,1$ & $-1,3$ & 0,6 & $-0,5$ & $-0,7$ & 1,1 & 0,5 & -0 & 1,3 & 0,7 & 0,2 \\
\hline $23 / 2$ & 900 & $-1,0$ & $-1,5$ & $-1,3$ & 1,0 & $-0,5$ & $-0,3$ & 1,5 & 0,5 & 0 & 1,3 & 0,3 & $-0,2$ \\
\hline $23 / 2$ & 930 & $-1,3$ & $-2,1$ & $-1,7$ & 1,3 & $-0,8$ & $-0,4$ & 2,1 & 0,8 & 0,4 & 1,7 & 0,4 & $-0,4$ \\
\hline $23 / 2$ & 1000 & $-1,0$ & $-1,7$ & $-1,4$ & 1,0 & $-0,7$ & $-0,4$ & 1,7 & 0,7 & 0,3 & 1,4 & 0,4 & $-0,3$ \\
\hline $23 / 2$ & 103 & $-0,8$ & $-1,7$ & $-1,4$ & 0,8 & $-0,9$ & $-0,6$ & 1,7 & 0,9 & 0 , & 1,4 & 0,6 & $-0,3$ \\
\hline $23 / 2$ & 110 & $-0,1$ & $-1,3$ & $-1,2$ & 0,1 & $-1,2$ & $-1,1$ & 1,3 & 1,2 & 0 , & 1,2 & 1,1 & $-0,1$ \\
\hline $23 / 2$ & 1130 & $-0,3$ & $-1,4$ & $-1,0$ & 0,3 & $-1,1$ & $-0,7$ & 1,4 & 1,1 & 0 & 1,0 & 0,7 & $-0,3$ \\
\hline $23 / 2$ & 1200 & $-0,5$ & $-1,7$ & $-1,0$ & 0,5 & $-1,2$ & $-0,6$ & 1,7 & 1,2 & 0,6 & 1,0 & 0,6 & $-0,6$ \\
\hline $23 / 2$ & 1230 & 0,0 & $-1,1$ & $-0,7$ & 0,0 & $-1,1$ & $-0,7$ & 1,1 & 1,1 & 0,4 & 0,7 & 0,7 & $-0,4$ \\
\hline $23 / 2$ & 1300 & $-0,2$ & $-1,3$ & $-1,1$ & 0,2 & $-1,1$ & $-0,9$ & 1,3 & 1,1 & 0,2 & 1,1 & 0,9 & $-0,2$ \\
\hline $23 / 2$ & 13 & 0,2 & $-1,1$ & $-1,1$ & $-0,2$ & $-1,3$ & $-1,3$ & 1,1 & 1,3 & 0 , & 1,1 & 1,3 & 0,0 \\
\hline $23 / 2$ & 1400 & $Z$ & $-1,1$ & $-0,9$ & $-0,2$ & $-1,3$ & $-1,1$ & 1,1 & 1,3 & 0,2 & 0,9 & 1,1 & $-0,2$ \\
\hline $23 / 2$ & 1430 & $-0,3$ & $-1,4$ & $-0,9$ & 0,3 & $-1,1$ & $-0,6$ & 1,4 & 1,1 & 0,5 & 0,9 & 0,6 & $-0,5$ \\
\hline $23 / 2$ & 1500 & $-0,3$ & $-1,4$ & $-1,2$ & 0,3 & $-1,2$ & $-0,9$ & 1,4 & 1,2 & 0,3 & 1,2 & 0,9 & $-0,3$ \\
\hline $23 / 2$ & 1530 & 0,1 & $-1,1$ & $-1,0$ & $-0,1$ & $-1,2$ & $-1,1$ & 1,1 & 1,2 & 0,1 & 1,0 & 1,1 & $-0,1$ \\
\hline $23 / 2$ & 16 & 0,1 & $-1,2$ & $-0,7$ & $-0,1$ & $-1,3$ & $-0,8$ & 1,2 & 1,3 & 0 & 0,7 & 0,8 & $-0,5$ \\
\hline $23 / 2$ & 16 & 5 & $-0,9$ & $-0,9$ & $-0,5$ & $-1,4$ & $-1,4$ & 0,9 & 1,4 & 0,0 & 0,9 & 1,4 & 0,0 \\
\hline $23 / 2$ & 1700 & 5 & $-0,8$ & $-0,9$ & $-0,5$ & $-1,2$ & $-1,4$ & 0,8 & 1,2 & $-0,2$ & 0,9 & 1,4 & 0,2 \\
\hline $23 / 2$ & 1730 & 0,9 & $-1,1$ & $-1,2$ & $-0,9$ & $-2,1$ & $-2,1$ & 1,1 & 2,1 & 0,0 & 1,2 & 2,1 & 0,0 \\
\hline $23 / 2$ & 1800 & $-0,5$ & $-1,0$ & $-1,0$ & 0,5 & $-0,5$ & $-0,5$ & 1,0 & 0,5 & 0,0 & 1,0 & 0,5 & 0,0 \\
\hline $23 / 2$ & 1830 & $-1,4$ & $-1,9$ & $-0,9$ & 1,4 & $-0,5$ & 0,5 & 1,9 & 0,5 & 1,0 & 0,9 & $-0,5$ & $-1,0$ \\
\hline $23 / 2$ & 190 & $-1,4$ & $-2,4$ & $-0,2$ & 1,4 & $-1,0$ & 1,2 & 2,4 & 1,0 & 2,2 & 0,2 & $-1,2$ & $-2,2$ \\
\hline $23 / 2$ & 193 & $-1,9$ & $-1,5$ & 0,9 & 1,9 & 0,4 & 2,8 & 1,5 & $-0,4$ & 2,4 & $-0,9$ & $-2,8$ & $-2,4$ \\
\hline $23 / 2$ & 2000 & $-2,3$ & $-0,2$ & 1,3 & 2,3 & 2,1 & 3,5 & 0,2 & $-2,1$ & 1,5 & $-1,3$ & $-3,5$ & $-1,5$ \\
\hline $23 / 2$ & 2030 & $-2,6$ & $-0,3$ & 0,8 & 2,6 & 2,3 & 3,4 & 0,3 & $-2,3$ & 1,1 & $-0,8$ & $-3,4$ & $-1,1$ \\
\hline $23 / 2$ & 2100 & $-2,2$ & 0,7 & 2,1 & 2,2 & 2,9 & 4,4 & $-0,7$ & $-2,9$ & 1,5 & $-2,1$ & $-4,4$ & $-1,5$ \\
\hline $23 / 2$ & 2130 & $-2,0$ & 0,6 & 2,7 & 2,0 & 2,6 & 4,7 & $-0,6$ & $-2,6$ & 2,1 & $-2,7$ & $-4,7$ & $-2,1$ \\
\hline $23 / 2$ & 2200 & -1.9 & 0,8 & 2,8 & 1.9 & 2,7 & 4,6 & $-0,8$ & -2.7 & 2,0 & $-2,8$ & -4.6 & $-2,0$ \\
\hline $23 / 2$ & 2230 & $-1,7$ & 1,4 & 2,6 & 1,7 & 3,2 & 4,4 & $-1,4$ & $-3,2$ & 1,2 & $-2,6$ & $-4,4$ & $-1,2$ \\
\hline $23 / 2$ & 2300 & $-1,2$ & 1,9 & 2,3 & 1,2 & 3,1 & 3,5 & $-1,9$ & $-3,1$ & 0,4 & $-2,3$ & $-3,5$ & $-0,4$ \\
\hline $23 / 2$ & 2330 & $-1,4$ & 2,5 & 2,6 & 1,4 & 3,9 & 4,0 & $-2,5$ & $-3,9$ & 0,1 & $-2,6$ & $-4,0$ & $-0,1$ \\
\hline $23 / 2$ & 2400 & $-1,0$ & 2,4 & 3,3 & 1,0 & 3,4 & 4,3 & $-2,4$ & $-3,4$ & 0,9 & $-3,3$ & $-4,3$ & $-0,9$ \\
\hline
\end{tabular}

Legenda: CI - Campus I; CII - Campus II; F - Fadisc; S - Samambaia 


\section{APÊNDICE E - DIFERENÇA DE TEMPERATURA ENTRE AS ESTAÇÕES CLIMÁTICAS NO DIA 24/02/2005.}

\begin{tabular}{|c|c|c|c|c|c|c|c|c|c|c|c|c|c|}
\hline dia & hora & $\begin{array}{l}\bar{\Xi} \\
\text { Ũ }\end{array}$ & $\frac{5}{3}$ & U & 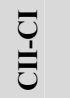 & $\stackrel{5}{\frac{5}{3}}$ & $\stackrel{\text { Pै }}{\tilde{U}}$ & $\begin{array}{l}\overline{1} \\
\overline{1}\end{array}$ & $\underset{\mathcal{I}}{\bar{I}}$ & 蛙 & ర్ & 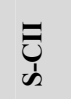 & 步 \\
\hline $24 / 2$ & 30 & $-0,9$ & 2,5 & 3,6 & 0,9 & 3,4 & 4,5 & $-2,5$ & $-3,4$ & 1,1 & $-3,6$ & $-4,5$ & $-1,1$ \\
\hline $24 / 2$ & 100 & $-0,9$ & 2,4 & 3,8 & 0,9 & 3,4 & 4,8 & $-2,4$ & $-3,4$ & 1,4 & $-3,8$ & $-4,8$ & $-1,4$ \\
\hline $24 / 2$ & 130 & $-0,9$ & 3,2 & 3,5 & 0,9 & 4,1 & 4,4 & $-3,2$ & $-4,1$ & 0,3 & $-3,5$ & $-4,4$ & $-0,3$ \\
\hline $24 / 2$ & 200 & $-0,5$ & 3,5 & 4,1 & 0,5 & 4,0 & 4,5 & $-3,5$ & $-4,0$ & 0,6 & $-4,1$ & $-4,5$ & $-0,6$ \\
\hline $24 / 2$ & 230 & $-0,2$ & 3,1 & 3,7 & 0,2 & 3,2 & 3,9 & $-3,1$ & $-3,2$ & 0,7 & $-3,7$ & $-3,9$ & $-0,7$ \\
\hline $24 / 2$ & 300 & $-0,5$ & 3,4 & 3,3 & 0,5 & 3,9 & 3,8 & $-3,4$ & $-3,9$ & $-0,1$ & $-3,3$ & $-3,8$ & 0,1 \\
\hline $24 / 2$ & 330 & $-0,7$ & 3,3 & 3,7 & 0,7 & 4,0 & 4,3 & $-3,3$ & $-4,0$ & 0,3 & $-3,7$ & $-4,3$ & $-0,3$ \\
\hline $24 / 2$ & 400 & $-0,7$ & 3,5 & 3,5 & 0,7 & 4,2 & 4,3 & $-3,5$ & $-4,2$ & 0,0 & $-3,5$ & $-4,3$ & 0,0 \\
\hline $24 / 2$ & 430 & $-0,9$ & 3,2 & 4,1 & 0,9 & 4,1 & 5,0 & $-3,2$ & $-4,1$ & 0,9 & $-4,1$ & $-5,0$ & $-0,9$ \\
\hline $24 / 2$ & 500 & $-0,8$ & 3,0 & 4,0 & 0,8 & 3,8 & 4,8 & $-3,0$ & $-3,8$ & 1,0 & $-4,0$ & $-4,8$ & $-1,0$ \\
\hline $24 / 2$ & 530 & $-0,8$ & 3,2 & 2,7 & 0,8 & 4,0 & 3,5 & $-3,2$ & $-4,0$ & $-0,4$ & $-2,7$ & $-3,5$ & 0,4 \\
\hline $24 / 2$ & 600 & $-0,9$ & 3,8 & 3,7 & 0,9 & 4,7 & 4,5 & $-3,8$ & $-4,7$ & $-0,2$ & $-3,7$ & $-4,5$ & 0,2 \\
\hline $24 / 2$ & 630 & $-0,6$ & 3,6 & 3,5 & 0,6 & 4,2 & 4,2 & $-3,6$ & $-4,2$ & 0,0 & $-3,5$ & $-4,2$ & 0,0 \\
\hline $24 / 2$ & 700 & $-1,1$ & 3,5 & 3,4 & 1,1 & 4,6 & 4,5 & $-3,5$ & $-4,6$ & $-0,1$ & $-3,4$ & $-4,5$ & 0,1 \\
\hline $24 / 2$ & 730 & $-0,4$ & 2,0 & 1,6 & 0,4 & 2,3 & 2,0 & $-2,0$ & $-2,3$ & $-0,3$ & $-1,6$ & $-2,0$ & 0,3 \\
\hline $24 / 2$ & 800 & $-0,9$ & $-0,9$ & $-1,0$ & 0,9 & 0,0 & $-0,1$ & 0,9 & 0,0 & $-0,1$ & 1,0 & 0,1 & 0,1 \\
\hline $24 / 2$ & 8 & $-0,4$ & $-1,2$ & $-1,1$ & 0,4 & $-0,8$ & $-0,7$ & 1,2 & 0,8 & 0,1 & 1,1 & 0,7 & $-0,1$ \\
\hline $24 / 2$ & 900 & 0,0 & $-1,0$ & $-0,8$ & 0,0 & $-1,1$ & $-0,8$ & 1,0 & 1,1 & 0,2 & 0,8 & 0,8 & $-0,2$ \\
\hline $24 / 2$ & 930 & $-0,8$ & $-1,1$ & $-0,8$ & 0,8 & $-0,3$ & 0,0 & 1,1 & 0,3 & 0,3 & 0,8 & 0,0 & $-0,3$ \\
\hline $24 / 2$ & 1000 & $-1,3$ & $-1,4$ & $-1,3$ & 1,3 & $-0,1$ & 0,0 & 1,4 & 0,1 & 0,1 & 1,3 & 0,0 & $-0,1$ \\
\hline $24 / 2$ & 1030 & $-1,1$ & $\begin{array}{l}-1,4 \\
\end{array}$ & $-1,2$ & 1,1 & $-0,3$ & $-0,2$ & 1,4 & 0,3 & 0,1 & 1,2 & 0,2 & $-0,1$ \\
\hline $24 / 2$ & 110 & $-0,7$ & $-1,5$ & $-1,2$ & 0,7 & $-0, \varepsilon$ & $-0,5$ & 1,5 & 0,8 & 0,3 & 1,2 & 0,5 & $-0,3$ \\
\hline $24 / 2$ & 1130 & $-0,4$ & $-1,6$ & $-0,9$ & 0,4 & $-1,2$ & $-0,5$ & 1,6 & 1,2 & 0,7 & 0,9 & 0,5 & $-0,7$ \\
\hline $24 / 2$ & 1200 & $-0,3$ & $-2,0$ & $-1,3$ & 0,3 & $-1,7$ & $-1,0$ & 2,0 & 1,7 & 0,7 & 1,3 & 1,0 & $-0,7$ \\
\hline $24 / 2$ & 1230 & $-0,1$ & $-1,6$ & $-0,9$ & 0,1 & $-1,5$ & $-0,9$ & 1,6 & 1,5 & 0,7 & 0,9 & 0,9 & $-0,7$ \\
\hline $24 / 2$ & 1300 & 0,5 & $-1,0$ & $-1,2$ & $-0,5$ & $-1,5$ & $-1,7$ & 1,0 & 1,5 & $-0,2$ & 1,2 & 1,7 & 0,2 \\
\hline $24 / 2$ & 1330 & $-0,2$ & $-1,7$ & $-1,6$ & 0,2 & $-1,5$ & $-1,4$ & 1,7 & 1,5 & 0,1 & 1,6 & 1,4 & $-0,1$ \\
\hline $24 / 2$ & 1400 & 0,0 & $-1,5$ & $-1,0$ & 0 & -1, & $-1,1$ & 1,5 & 1,5 & 0,5 & 1,0 & 1,1 & $-0,5$ \\
\hline $24 / 2$ & 1430 & 0,2 & $-1,1$ & $-0,9$ & $-0,2$ & $-1,4$ & $-1,2$ & 1,1 & 1,4 & 0,2 & 0,9 & 1,2 & $-0,2$ \\
\hline $24 / 2$ & 1500 & 0,8 & $-1,4$ & $-1,0$ & $-0,8$ & $-2,2$ & $-1,8$ & 1,4 & 2,2 & 0,3 & 1,0 & 1,8 & $-0,3$ \\
\hline $24 / 2$ & 1530 & 1,1 & $-1,3$ & $-1,0$ & $-1,1$ & $-2,4$ & $-2,1$ & 1,3 & 2,4 & 0,2 & 1,0 & 2,1 & $-0,2$ \\
\hline $24 / 2$ & 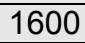 & 0,6 & $-1,2$ & $-0,8$ & $-0,6$ & -1, & $-1,4$ & 1,2 & 1,8 & 0,4 & 0,8 & 1,4 & $-0,4$ \\
\hline $24 / 2$ & & 0,5 & $-0,7$ & $-0,7$ & $-0,5$ & $-1,2$ & $-1,2$ & 0,7 & 1,2 & 0,1 & 0,7 & 1,2 & $-0,1$ \\
\hline $24 / 2$ & 1700 & 0,0 & $-1,6$ & $-0,8$ & 0,0 & $-1,5$ & $-0,8$ & 1,6 & 1,5 & 0,7 & 0,8 & 0,8 & $-0,7$ \\
\hline $24 / 2$ & 1730 & $-0,2$ & $-1,8$ & $-1,3$ & 0,2 & $-1,6$ & $-1,1$ & 1,8 & 1,6 & 0,5 & 1,3 & 1,1 & $-0,5$ \\
\hline $24 / 2$ & 1800 & 0,6 & $-1,5$ & $-0,7$ & $-0,6$ & $-2,1$ & $-1,3$ & 1,5 & 2,1 & 0,8 & 0,7 & 1,3 & $-0,8$ \\
\hline $24 / 2$ & 1830 & $-0,7$ & $-1,7$ & $-0,5$ & 0,7 & $-0,9$ & 0,2 & 1,7 & 0,9 & 1,2 & 0,5 & $-0,2$ & $-1,2$ \\
\hline $24 / 2$ & 190 & $-1,4$ & $-2,1$ & $-0,4$ & 1,4 & $-0,7$ & 1,0 & 2,1 & 0,7 & 1,7 & 0,4 & $-1,0$ & $-1,7$ \\
\hline $24 / 2$ & 1930 & $-1,7$ & $-1,7$ & $-0,4$ & 1,7 & 0,0 & 1,3 & 1,7 & 0,0 & 1,3 & 0,4 & $-1,3$ & $-1,3$ \\
\hline $24 / 2$ & 2000 & $-0,5$ & $-1,9$ & $-0,5$ & 0,5 & $-1,4$ & 0,1 & 1,9 & 1,4 & 1,5 & 0,5 & $-0,1$ & $-1,5$ \\
\hline $24 / 2$ & 2030 & $-0,1$ & $-2,2$ & $-0,5$ & 0,1 & $-2,0$ & $-0,4$ & 2,2 & 2,0 & 1,6 & 0,5 & 0,4 & $-1,6$ \\
\hline $24 / 2$ & 2100 & $-0,1$ & $-1,9$ & $-0,6$ & 0,1 & $-1,9$ & $-0,5$ & 1,9 & 1,9 & 1,4 & 0,6 & 0,5 & $-1,4$ \\
\hline $24 / 2$ & 2130 & $-0,2$ & $-1,7$ & $-0,6$ & 0,2 & $-1,5$ & $-0,4$ & 1,7 & 1,5 & 1,1 & 0,6 & 0,4 & $-1,1$ \\
\hline $24 / 2$ & 2200 & $-0,3$ & $-1,5$ & $-0,6$ & 0,3 & $-1,2$ & $-0,3$ & 1,5 & 1,2 & 0,9 & 0,6 & 0,3 & $-0,9$ \\
\hline $24 / 2$ & 230 & $-0,4$ & $-1,5$ & $-0,6$ & 0,4 & $-1,1$ & $-0,2$ & 1,5 & 1,1 & 08 & 0,6 & 0,2 & $-0,8$ \\
\hline $24 / 2$ & 2300 & $-0,2$ & $-1,6$ & $-0,7$ & 0,2 & $-1,4$ & $-0,5$ & 1,6 & 1,4 & 0,8 & 0,7 & 0,5 & $-0,8$ \\
\hline $24 / 2$ & 2330 & 0,1 & $-1,5$ & $-0,7$ & $-0,1$ & $-1,6$ & $-0,8$ & 1,5 & 1,6 & 0,8 & 0,7 & 0,8 & $-0,8$ \\
\hline $24 / 2$ & 2400 & $-0,6$ & $-1,4$ & $-0,6$ & 0,6 & $-0,8$ & 0,0 & 1,4 & 0,8 & 0,8 & 0,6 & 0,0 & $-0,8$ \\
\hline
\end{tabular}

Legenda: Cl - Campus I; CII - Campus II; F - Fadisc; S - Samambaia 


\section{APÊNDICE F - DIFERENÇA DE TEMPERATURA ENTRE AS ESTAÇÕES CLIMÁTICAS NO DIA 25/02/2005.}

\begin{tabular}{|c|c|c|c|c|c|c|c|c|c|c|c|c|c|}
\hline dia & hora & $\begin{array}{l}\bar{u} \\
\dot{u}\end{array}$ & $\frac{5}{1}$ & $\frac{\tilde{I}}{0}$ & $\underset{\text { J }}{\tilde{J}}$ & $\stackrel{\frac{5}{1}}{\overline{3}}$ & $\stackrel{\tilde{1}}{=}$ & $\underset{I}{\beth}$ & $\underset{I}{E}$ & I & $\underset{n}{\tilde{D}}$ & $\underbrace{}_{n}$ & 晸 \\
\hline $25 / 2$ & 30 & $-0,8$ & $-1,9$ & $-0,6$ & 0,8 & $-1,0$ & 0,2 & 1,9 & 11.0 & 1,3 & 0.6 & $-0,2$ & $-1,3$ \\
\hline $25 / 2$ & 100 & $-0,9$ & $-1,8$ & $-0,6$ & 0,9 & $-0,9$ & 0,3 & 1,8 & 0,9 & 1,2 & 0,6 & $-0,3$ & $-1,2$ \\
\hline $25 / 2$ & 130 & $-0,3$ & $-1,2$ & $-0,5$ & 0,3 & $-0,9$ & $-0,2$ & 1,2 & 0,9 & 0,7 & 0,5 & 0,2 & $-0,7$ \\
\hline $25 / 2$ & 200 & $-0,1$ & $-0,7$ & $-0,1$ & 0,1 & $-0,6$ & 0,0 & 0,7 & 0,6 & 0,6 & 0,1 & 0,0 & $-0,6$ \\
\hline $25 / 2$ & 230 & $-0,4$ & $-1,1$ & $-0,3$ & 0,4 & $-0,7$ & 0,1 & 1,1 & 0,7 & 0,9 & 0,3 & $-0,1$ & $-0,9$ \\
\hline $25 / 2$ & 300 & 0,0 & $-0,9$ & $-0,2$ & 0,0 & $-1,0$ & $-0,3$ & 0,9 & 1,0 & 0,7 & 0,2 & 0,3 & $-0,7$ \\
\hline $25 / 2$ & 330 & 0,1 & $-0,5$ & 0,3 & $-0,1$ & $-0,6$ & 0,2 & 0,5 & 0,6 & 0,9 & $-0,3$ & $-0,2$ & $-0,9$ \\
\hline $25 / 2$ & 400 & 0,6 & 0,5 & 0,9 & $-0,6$ & $-0,1$ & 0,2 & $-0,5$ & 0,1 & 0,3 & $-0,9$ & $-0,2$ & $-0,3$ \\
\hline $25 / 2$ & 430 & 0,6 & 0,5 & 0,9 & $-0,6$ & $-0,1$ & 0,4 & $-0,5$ & 0,1 & 0,4 & $-0,9$ & $-0,4$ & $-0,4$ \\
\hline $25 / 2$ & 500 & 0,4 & 0,9 & 1,4 & $-0,4$ & 0,4 & 0,9 & $-0,9$ & $-0,4$ & 0,5 & $-1,4$ & $-0,9$ & $-0,5$ \\
\hline $25 / 2$ & 530 & 0,4 & 0,7 & 1,3 & $-0,4$ & 0,3 & 0,9 & $-0,7$ & $-0,3$ & 0,6 & $-1,3$ & $-0,9$ & $-0,6$ \\
\hline $25 / 2$ & 600 & 0,4 & 0,7 & 0,8 & $-0,4$ & 0,3 & 0,4 & $-0,7$ & $-0,3$ & 0,1 & $-0,8$ & $-0,4$ & $-0,1$ \\
\hline $25 / 2$ & 630 & 0,3 & 0,3 & 0,9 & $-0,3$ & 0,0 & 0,6 & $-0,3$ & 0,0 & 0,6 & $-0,9$ & $-0,6$ & $-0,6$ \\
\hline $25 / 2$ & 700 & 0,6 & 0,2 & 0,6 & $-0,6$ & $-0,5$ & 0,0 & $-0,2$ & 0,5 & 0,5 & $-0,6$ & 0,0 & $-0,5$ \\
\hline $25 / 2$ & 730 & 0,3 & $-0,1$ & 0,2 & $-0,3$ & $-0,4$ & 0,0 & 0,1 & 0,4 & 0,3 & $-0,2$ & 0,0 & $-0,3$ \\
\hline $25 / 2$ & 800 & $-1,0$ & $-1,0$ & $-0,2$ & 1,0 & 0,0 & 0,8 & 1,0 & 0,0 & 0 & 0,2 & $-0,8$ & $-0,8$ \\
\hline $25 / 2$ & 830 & $-0,1$ & $-1,0$ & $-0,7$ & 0,1 & $-0,9$ & $-0,6$ & 1,0 & 0,9 & 0 & 0,7 & 0,6 & $-0,3$ \\
\hline $25 / 2$ & 900 & $-0,3$ & $-0,5$ & $-0,6$ & 0,3 & $-0,3$ & $-0,3$ & 0,5 & 0,3 & 0,0 & 0,6 & 0,3 & 0,0 \\
\hline $25 / 2$ & 930 & $-0,9$ & $-1,1$ & $-0,9$ & 0,9 & $-0,2$ & 0,0 & 1,1 & 0,2 & 0,2 & 0,9 & 0,0 & $-0,2$ \\
\hline $25 / 2$ & 1000 & $-0,3$ & $-0,8$ & $-0,9$ & 0,3 & $-0,6$ & $-0,6$ & 0,8 & 0,6 & 0,0 & 0,9 & 0,6 & 0,0 \\
\hline $25 / 2$ & 103 & $-0,7$ & $-1,3$ & $-1,0$ & 0,7 & $-0,6$ & $-0,3$ & 1,3 & 0,6 & 0,2 & 1,0 & 0,3 & $-0,2$ \\
\hline $25 / 2$ & 110 & $-0,9$ & $-1,7$ & $-1,4$ & 0,9 & $-0,8$ & $-0,4$ & 1,7 & 0,8 & 0 , & 1,4 & 0,4 & $-0,4$ \\
\hline $25 / 2$ & 1130 & $-0,7$ & $-1,8$ & $-1,3$ & 0,7 & $-1,1$ & -0, & 1,8 & 1,1 & 0 & 1, & 0,6 & $-0,5$ \\
\hline $25 / 2$ & 1200 & $-0,1$ & $-1,3$ & $-1,2$ & 0,1 & $-1,2$ & $-1,2$ & 1,3 & 1,2 & 0,1 & 1,2 & 1,2 & $-0,1$ \\
\hline $25 / 2$ & 1230 & 0,3 & $-1,4$ & $-1,4$ & $-0,3$ & $-1,6$ & $-1,7$ & 1,4 & 1,6 & 0,0 & 1,4 & 1,7 & 0,0 \\
\hline $25 / 2$ & 1300 & $-0,3$ & $-1,1$ & $-1,1$ & 0,3 & $-0,8$ & $-0,8$ & 1,1 & 0,8 & 0, & 1,1 & 0,8 & 0,0 \\
\hline $25 / 2$ & 13 & 0,9 & $-0,3$ & $-0,8$ & $-0,9$ & $-1,2$ & $-1,7$ & 0,3 & 1,2 & $-0,5$ & 0,8 & 1,7 & 0,5 \\
\hline $25 / 2$ & 1400 & 1.4 & $-0,1$ & 0,0 & $-1,4$ & $-1,4$ & $-1,4$ & 0,1 & 1,4 & 0,0 & 0,0 & 1,4 & 0,0 \\
\hline $25 / 2$ & 1430 & 1,2 & 0,4 & $-0,3$ & $-1,2$ & $-0,9$ & $-1,5$ & $-0,4$ & 0,9 & $-0,6$ & 0,3 & 1,5 & 0,6 \\
\hline $25 / 2$ & 1500 & 2,1 & 1,2 & 0,0 & $-2,1$ & $-0,9$ & $-2,1$ & $-1,2$ & 0,9 & $-1,1$ & 0,0 & 2,1 & 1,1 \\
\hline $25 / 2$ & 1530 & 1,0 & 0,3 & $-0,1$ & $-1,0$ & $-0,7$ & $-1,1$ & $-0,3$ & 0,7 & $\begin{array}{l}-0,4 \\
\end{array}$ & 0,1 & 1,1 & 0,4 \\
\hline $25 / 2$ & 160 & $-1,1$ & $-1,2$ & $-0,7$ & 1,1 & $-0,1$ & 0,4 & 1,2 & 0,1 & 0,5 & 0,7 & $-0,4$ & $-0,5$ \\
\hline $25 / 2$ & 163 & $-1,3$ & $-1,3$ & $-0,7$ & 1,3 & 0,0 & 0 & 1,3 & 0,0 & 0,6 & 0,7 & $-0,6$ & $-0,6$ \\
\hline $25 / 2$ & 1700 & $-0,8$ & 0,0 & $-0,5$ & 0,8 & 0,8 & 0,3 & 0,0 & $-0,8$ & $-0,6$ & 0,5 & $-0,3$ & 0,6 \\
\hline $25 / 2$ & 1730 & $-0,2$ & $-0,1$ & $-0,9$ & 0,2 & 0,0 & $-0,7$ & 0,1 & 0,0 & $-0,8$ & 0,9 & 0,7 & 0,8 \\
\hline $25 / 2$ & 1800 & $-0,2$ & $-0,5$ & $-0,8$ & 0,2 & $-0,3$ & $-0,6$ & 0,5 & 0,3 & $-0,2$ & 0,8 & 0,6 & 0,2 \\
\hline $25 / 2$ & 1830 & 0,1 & $-0,8$ & $-0,6$ & $-0,1$ & $-0,9$ & $-0,7$ & 0,8 & 0,9 & 0,2 & 0,6 & 0,7 & $-0,2$ \\
\hline $25 / 2$ & 190 & $-0,8$ & $-0,6$ & $-0,6$ & 0,8 & 0,1 & 0,2 & 0,6 & $-0,1$ & 0,1 & 0,6 & $-0,2$ & $-0,1$ \\
\hline $25 / 2$ & 193 & $-0,5$ & $-0,1$ & $-0,4$ & 0,5 & 0,4 & 0,1 & 0,1 & $-0,4$ & $-0,3$ & 0,4 & $-0,1$ & 0,3 \\
\hline $25 / 2$ & 2000 & $-0,1$ & $-0,4$ & $-0,8$ & 0,1 & $-0,3$ & $-0,7$ & 0,4 & 0,3 & $-0,4$ & 0,8 & 0,7 & 0,4 \\
\hline $25 / 2$ & 2030 & $-0,7$ & $-0,7$ & $-0,5$ & 0,7 & 0,0 & 0,1 & 0,7 & 0,0 & 0,1 & 0,5 & $-0,1$ & $-0,1$ \\
\hline $25 / 2$ & 2100 & $-0,5$ & 0,7 & $-0,1$ & 0,5 & 1,2 & 0,4 & $-0,7$ & $-1,2$ & $-0,8$ & 0,1 & $-0,4$ & 0,8 \\
\hline $25 / 2$ & 2130 & $-1,1$ & $-0,1$ & $-0,7$ & 1,1 & 0,9 & 0,4 & 0,1 & $-0,9$ & $-0,6$ & 0,7 & $-0,4$ & 0,6 \\
\hline $25 / 2$ & 2200 & 0,2 & 0,1 & $-0,3$ & $-0,2$ & $-0,1$ & $-0,5$ & $-0,1$ & 0,1 & $-0,4$ & 0,3 & 0,5 & 0,4 \\
\hline $25 / 2$ & 2230 & 0, & $-0,5$ & $-0,2$ & $-0,3$ & $-0,7$ & $-0,4$ & 0,5 & 0,7 & 0,3 & 0,2 & 0,4 & $-0,3$ \\
\hline $25 / 2$ & 2300 & $-0,1$ & $-0,7$ & $-0,3$ & 0,1 & $-0,6$ & $-0,2$ & 0,7 & 0,6 & 0,4 & 0,3 & 0,2 & $-0,4$ \\
\hline $25 / 2$ & 2330 & $-0,3$ & $-1,0$ & $-0,4$ & 0,3 & $-0,8$ & $-0,2$ & 1,0 & 0,8 & 0,6 & 0,4 & 0,2 & $-0,6$ \\
\hline $25 / 2$ & 2400 & $-0,2$ & $-0,9$ & $-0,4$ & 0,2 & $-0,8$ & $-0,2$ & 0,9 & 0,8 & 0,5 & 0,4 & 0,2 & $-0,5$ \\
\hline
\end{tabular}

Legenda: Cl - Campus I; CII - Campus II; F - Fadisc; S - Samambaia 


\section{APÊNDICE G - DIFERENCCA DE TEMPERATURA ENTRE AS ESTAÇÕES CLIMÁTICAS NO DIA 26/02/2005.}

\begin{tabular}{|c|c|c|c|c|c|c|c|c|c|c|c|c|c|}
\hline dia & hora & $\begin{array}{l}\text { ఫ్ } \\
\text { ú }\end{array}$ & $\frac{5}{1}$ & U & $\begin{array}{l}\underset{1}{\tilde{J}} \\
\end{array}$ & $\stackrel{5}{\frac{5}{3}}$ & $\stackrel{\hat{U}}{\bar{U}}$ & ర్ & $\underset{\mathrm{I}}{\bar{I}}$ & 跬 & $\underset{\text { Ḋ }}{\bar{n}}$ & छ్ & $\begin{array}{l}\frac{1}{1} \\
\vdots\end{array}$ \\
\hline $26 / 2$ & 30 & 0,0 & $-0,9$ & $-0,4$ & 0,0 & $-0,8$ & $-0,4$ & 0,9 & 0,8 & 0,5 & 0,4 & 0,4 & $-0,5$ \\
\hline $26 / 2$ & 100 & $-0,1$ & $-0,9$ & $-0,4$ & 0,1 & $-0,8$ & $-0,3$ & 0,9 & 0,8 & 0,4 & 0,4 & 0,3 & $-0,4$ \\
\hline $26 / 2$ & 130 & $-0,1$ & $-1,0$ & $-0,4$ & 0,1 & $-0,9$ & $-0,3$ & 1,0 & 0,9 & 0,6 & 0,4 & 0,3 & $-0,6$ \\
\hline $26 / 2$ & 200 & 0,3 & $-0,7$ & $-0,3$ & $-0,3$ & $-1,0$ & $-0,6$ & 0,7 & 1,0 & 0,4 & 0,3 & 0,6 & $-0,4$ \\
\hline $26 / 2$ & 230 & 0,0 & $-0,9$ & $-0,4$ & 0,0 & $-0,9$ & $-0,4$ & 0,9 & 0,9 & 0,6 & 0,4 & 0,4 & $-0,6$ \\
\hline $26 / 2$ & 300 & 0,1 & $-1,0$ & $-0,4$ & $-0,1$ & $-1,1$ & $-0,5$ & 1,0 & 1,1 & 0,6 & 0,4 & 0,5 & $-0,6$ \\
\hline $26 / 2$ & 330 & 0,2 & $-1,1$ & $-0,3$ & $-0,2$ & $-1,3$ & $-0,4$ & 1,1 & 1,3 & 0,9 & 0,3 & 0,4 & $-0,9$ \\
\hline $26 / 2$ & 400 & $-0,1$ & $-1,2$ & $-0,4$ & 0,1 & $-1,2$ & $-0,3$ & 1,2 & 1,2 & 0,8 & 0,4 & 0,3 & $-0,8$ \\
\hline $26 / 2$ & 430 & $-0,2$ & $-1,5$ & $-0,4$ & 0,2 & $-1,3$ & $-0,3$ & 1,5 & 1,3 & 1,0 & 0,4 & 0,3 & $-1,0$ \\
\hline $26 / 2$ & 500 & 0,1 & $-1,2$ & $-0,3$ & $-0,1$ & $-1,3$ & $-0,4$ & 1,2 & 1,3 & 0,9 & 0,3 & 0,4 & $-0,9$ \\
\hline $26 / 2$ & 5 & $-0,1$ & $-0,9$ & $-0,3$ & 0,1 & $-0,9$ & $-0,3$ & 0,9 & 0,9 & 0,6 & 0,3 & 3 & $-0,6$ \\
\hline $26 / 2$ & 600 & 0,1 & $-0,9$ & $-0,3$ & $-0,1$ & $-1,1$ & $-0,4$ & 0,9 & 1,1 & 0,6 & 0,3 & 1,4 & $-0,6$ \\
\hline $26 / 2$ & 630 & 0,1 & $-0,9$ & $-0,3$ & $-0,1$ & $-1,1$ & $-0,4$ & 0,9 & 1,1 & 0,6 & 0,3 & 0,4 & $-0,6$ \\
\hline $26 / 2$ & 700 & 0,0 & $-0,8$ & $-0,4$ & 0,0 & $-0,9$ & $-0,4$ & 0,8 & 0,9 & 0,5 & 0,4 & 0,4 & $-0,5$ \\
\hline $26 / 2$ & 730 & $-0,2$ & $-0,9$ & $-0,5$ & 0,2 & $-0,6$ & $-0,3$ & 0,9 & 0,6 & 0,3 & 0,5 & 0,3 & $-0,3$ \\
\hline $26 / 2$ & 80 & $-0,1$ & $-0,8$ & $-0,4$ & 0,1 & $-0,7$ & $-0,3$ & 0 & 0 , & 0,4 & 0,4 & 3 & $-0,4$ \\
\hline $26 / 2$ & 830 & $-0,2$ & $-0,9$ & $-0,5$ & 0,2 & $-0,7$ & $-0,3$ & 0 & 0,7 & 0,3 & 0,5 & 0,3 & $-0,3$ \\
\hline $26 / 2$ & 900 & $-0,3$ & $-0,9$ & $-0,6$ & 0,3 & $-0,6$ & $-0,3$ & 0,9 & 0,6 & 0,3 & 0,6 & 0,3 & $-0,3$ \\
\hline $26 / 2$ & 930 & $-0,3$ & $-0,9$ & $-0,6$ & 0,3 & $-0,6$ & $-0,3$ & 0,9 & 0,6 & 0,3 & 0,6 & 0,3 & $-0,3$ \\
\hline $26 / 2$ & 1000 & $-1,2$ & $-1,4$ & $-0,9$ & 1,2 & $-0,2$ & 0,2 & 1.4 & 0,2 & 0,4 & 0,9 & $-0,2$ & $-0,4$ \\
\hline $26 / 2$ & 1030 & $-0,1$ & $-0,8$ & $-0,7$ & 0,1 & $-0,7$ & $-0,6$ & $0, \varepsilon$ & 0,7 & 0,1 & 0,7 & 0,6 & $-0,1$ \\
\hline $26 / 2$ & 110 & $-0,4$ & -1.1 & $-0,8$ & 0,4 & -0.7 & $-0,4$ & 1 & 0.7 & 0,3 & 0,8 & 0,4 & $-0,3$ \\
\hline $26 / 2$ & 1130 & $-0,9$ & -1 & $-0,9$ & 0,9 & $-0,7$ & 0,0 & 1, & 0 & 0,7 & 0,9 & 0,0 & $-0,7$ \\
\hline $26 / 2$ & 1200 & $-1,0$ & $-1,3$ & $-0,9$ & 1,0 & $-0,4$ & 0,1 & 1,2 & 0,4 & 0,4 & 0,9 & $-0,1$ & $-0,4$ \\
\hline $26 / 2$ & 1230 & $-0,7$ & $-1,2$ & $-1,2$ & 0,7 & $-0,6$ & $-0,5$ & 1,2 & 0,6 & 0,1 & 1,2 & 0,5 & $-0,1$ \\
\hline $26 / 2$ & 1300 & 0,3 & $-0,5$ & $-0,8$ & $-0,3$ & $-0,8$ & $-1,1$ & 0,5 & 0,8 & $-0,3$ & 0,8 & 1,1 & 0,3 \\
\hline $26 / 2$ & 13 & $-0,5$ & $-1,2$ & $-1,0$ & 0,5 & $-0,7$ & $-0,5$ & 1,2 & 0,7 & 0,2 & 1,0 & 0,5 & $-0,2$ \\
\hline $26 / 2$ & 1400 & 0,2 & $-0,8$ & $-1,0$ & $-0,2$ & $-1,0$ & $-1,2$ & 0,8 & 1,0 & $-0,2$ & 1,0 & 1,2 & 0,2 \\
\hline $26 / 2$ & 1430 & 2,2 & 0 , & $-0,3$ & $-2,2$ & $-1,8$ & $-2,4$ & $-0,4$ & 1,8 & $-0,7$ & 0,3 & 2,4 & 0,7 \\
\hline $26 / 2$ & 1500 & 1,7 & 0 , & $-0,1$ & $-1,7$ & $-1,4$ & $-1,8$ & $-0,3$ & 1,4 & $-0,4$ & 0,1 & 1,8 & 0,4 \\
\hline $26 / 2$ & 1530 & $-0,4$ & $-1,0$ & $-0,4$ & 0,4 & $-0,5$ & 0,1 & 1, & 0,5 & 0,6 & 0,4 & $-0,1$ & $-0,6$ \\
\hline $26 / 2$ & 16 & $-1,0$ & $-1,3$ & $-0,6$ & 1,0 & $-0,3$ & 0,4 & 1, & 0,3 & 0,7 & 0,6 & $-0,4$ & $-0,7$ \\
\hline $26 / 2$ & 16 & -1 & -1 , & $-0,9$ & 0,8 & $-1,1$ & $-0,1$ & 1 & 1,1 & 1,0 & 0,9 & 0,1 & $-1,0$ \\
\hline $26 / 2$ & 1700 & $-1,3$ & $-2,9$ & $-1,6$ & 1,3 & $-1,6$ & $-0,3$ & 2,9 & 1,6 & 1,3 & 1,6 & 0,3 & $-1,3$ \\
\hline $26 / 2$ & 1730 & $-0,1$ & $-1,7$ & $-1,7$ & 0,1 & $-1,6$ & $-1,5$ & 1,7 & 1,6 & 0,1 & 1,7 & 1,5 & $-0,1$ \\
\hline $26 / 2$ & 1800 & 1,1 & $-0,3$ & $-1,0$ & $-1,1$ & $-1,4$ & $-2,0$ & 0,3 & 1,4 & $-0,6$ & 1,0 & 2,0 & 0,6 \\
\hline $26 / 2$ & 183 & 0,8 & $-0,6$ & $-0,6$ & $-0,8$ & $-1,4$ & $-1,4$ & 0,6 & 1,4 & 0,0 & 0,6 & 1,4 & 0,0 \\
\hline $26 / 2$ & 19 & $-0,1$ & $-0,9$ & $-0,4$ & 0,1 & $-0,8$ & $-0,3$ & 0 & 0 , & 0,5 & 0,4 & 0,3 & $-0,5$ \\
\hline $26 / 2$ & 193 & 0,2 & $-0,6$ & $-0,4$ & $-0,2$ & $-0,8$ & $-0,6$ & & 0,8 & 0,3 & 0,4 & 0,6 & $-0,3$ \\
\hline $26 / 2$ & 2000 & 0,3 & $-0,6$ & $-0,4$ & $-0,3$ & $-0,8$ & $-0,6$ & 0,6 & 0,8 & 0,2 & 0,4 & 0,6 & $-0,2$ \\
\hline $26 / 2$ & 2030 & $-0,2$ & $-0,6$ & $-0,2$ & 0,2 & $-0,4$ & 0,0 & 0,6 & 0,4 & 0,4 & 0,2 & 0,0 & $-0,4$ \\
\hline $26 / 2$ & 2100 & $-0,5$ & $-0,4$ & $-0,3$ & 0,5 & 0,1 & 0,2 & 0,4 & $-0,1$ & 0,1 & 0,3 & $-0,2$ & $-0,1$ \\
\hline $26 / 2$ & 2130 & 0,1 & $\begin{array}{l}-0,4 \\
\end{array}$ & $-0,3$ & $-0,1$ & $-0,5$ & $-0,4$ & 0,4 & 0,5 & 0,1 & 0,3 & 0,4 & $-0,1$ \\
\hline $26 / 2$ & 220 & 0.5 & $-0,6$ & -0.2 & $-0,5$ & $-1,2$ & $-0,8$ & 0 & $\overline{1,2}$ & 0,4 & 0,2 & 0,8 & $-0,4$ \\
\hline $26 / 2$ & 22 & 0 & $-0,8$ & & & $-1,5$ & $-0,9$ & 0, & 1,5 & 0,6 & 0,2 & 0,9 & $-0,6$ \\
\hline $26 / 2$ & 2300 & 0,8 & $-0,5$ & $-0,1$ & $-0,8$ & $-1,3$ & $-1,0$ & 05 & 1,3 & 0,4 & 0,1 & 1,0 & $-0,4$ \\
\hline $26 / 2$ & 2330 & 0,4 & $-0,8$ & $-0,4$ & $-0,4$ & $-1,2$ & $-0,7$ & 0,8 & 1,2 & 0,5 & 0,4 & 0,7 & $-0,5$ \\
\hline $26 / 2$ & 2400 & 0,3 & $-0,8$ & $-0,3$ & $-0,3$ & $-1,1$ & $-0,6$ & 0,8 & 1,1 & 0,5 & 0,3 & 0,6 & $-0,5$ \\
\hline
\end{tabular}

Legenda: CI - Campus I; CII - Campus II; F - Fadisc; S - Samambaia 


\section{APÊNDICE H - DIFERENÇA DE TEMPERATURA ENTRE AS ESTAÇÕES CLIMÁTICAS NO DIA 27/02/2005.}

\begin{tabular}{|c|c|c|c|c|c|c|c|c|c|c|c|c|c|}
\hline dia & hora & $\begin{array}{l}\bar{J} \\
\dot{J}\end{array}$ & $\frac{\pi}{u}$ & $\frac{0}{0}$ & $\begin{array}{l}\bar{I} \\
\stackrel{\Xi}{J}\end{array}$ & 立 & $\stackrel{\underline{P}}{\tilde{u}}$ & $\underset{\underline{I}}{\bar{I}}$ & $\underset{I}{\bar{I}}$ & 望 & ర్ర & ర్ & 离 \\
\hline $27 / 2$ & 30 & 0,3 & $-0,9$ & $-0,3$ & $-0,3$ & $-1,2$ & $-0,6$ & 0,9 & 1,2 & 0,6 & 0,3 & 0,6 & $-0,6$ \\
\hline $27 / 2$ & 100 & 0,4 & $-0,8$ & $-0,3$ & $-0,4$ & $-1,2$ & $-0,6$ & 0,8 & 1,2 & 0,6 & 0,3 & 0,6 & $-0,6$ \\
\hline $27 / 2$ & 130 & 0,4 & $-0,6$ & $-0,3$ & $-0,4$ & $-1,0$ & $-0,7$ & 0,6 & 1,0 & 0,3 & 0,3 & 0,7 & $-0,3$ \\
\hline $27 / 2$ & 200 & 0,3 & $-0,6$ & $-0,3$ & $-0,3$ & $-0,9$ & $-0,6$ & 0,6 & 0,9 & 0,3 & 0,3 & 0,6 & $-0,3$ \\
\hline $27 / 2$ & 230 & 0,3 & $-0,6$ & $-0,3$ & $-0,3$ & $-0,8$ & $-0,5$ & 0,6 & 0,8 & 0,3 & 0,3 & 0,5 & $-0,3$ \\
\hline $27 / 2$ & 300 & 0,5 & $-0,4$ & $-0,3$ & $-0,5$ & $-0,9$ & $-0,7$ & 0,4 & 0,9 & 0,1 & 0,3 & 0,7 & $-0,1$ \\
\hline $27 / 2$ & 330 & $-0,1$ & $-0,5$ & $-0,2$ & 0,1 & $-0,4$ & $-0,1$ & 0,5 & 0,4 & 0,3 & 0,2 & 0,1 & $-0,3$ \\
\hline $27 / 2$ & 400 & $-0,4$ & $-0,6$ & $-0,3$ & 0,4 & $-0,2$ & 0,1 & 0,6 & 0,2 & 0,3 & 0,3 & $-0,1$ & $-0,3$ \\
\hline $27 / 2$ & 430 & 0,2 & $-0,5$ & $-0,4$ & $-0,2$ & $-0,7$ & $-0,6$ & 0,5 & 0,7 & 0,1 & 0,4 & 0,6 & $-0,1$ \\
\hline $27 / 2$ & 500 & 0,2 & $-0,4$ & $-0,4$ & $-0,2$ & $-0,6$ & $-0,6$ & 0,4 & 0,6 & 0,0 & 0,4 & 0,6 & 0,0 \\
\hline $27 / 2$ & 530 & 0,2 & $-0,3$ & $-0,3$ & $-0,2$ & $-0,6$ & $-0,5$ & 0,3 & 0,6 & 0,0 & 0,3 & 0,5 & 0,0 \\
\hline $27 / 2$ & 600 & 0,0 & $-0,5$ & $-0,3$ & 0,0 & $-0,5$ & $-0,3$ & 0,5 & 0,5 & 0,3 & 0,3 & 0,3 & $-0,3$ \\
\hline $27 / 2$ & 630 & $-0,2$ & $-0,8$ & $-0,3$ & 0,2 & $-0,6$ & $-0,1$ & 0,8 & 0,6 & 0,5 & 0,3 & 0,1 & $-0,5$ \\
\hline $27 / 2$ & 700 & $-0,6$ & $-1,0$ & $-0,5$ & 0,6 & $-0,4$ & 0,1 & 1,0 & 0,4 & 0,5 & 0,5 & $-0,1$ & $-0,5$ \\
\hline $27 / 2$ & 730 & $-0,7$ & $-1,1$ & $-0,7$ & 0,7 & $-0,3$ & 0,1 & 1,1 & 0,3 & 0,4 & 0,7 & $-0,1$ & $-0,4$ \\
\hline $27 / 2$ & 800 & $-0,4$ & $-1,0$ & $-0,7$ & 0,4 & $-0,5$ & $-0,3$ & 1,0 & 0,5 & 0, & 0,7 & 0,3 & $-0,3$ \\
\hline $27 / 2$ & 830 & $-0,2$ & $-0,8$ & $-0,6$ & 0,2 & $-0,6$ & $-0,4$ & 0,8 & 0,6 & 0 , & 0,6 & 0,4 & $-0,2$ \\
\hline $27 / 2$ & 900 & $-0,6$ & $-1,1$ & $-0,8$ & 0,6 & $-0,5$ & $-0,2$ & 1,1 & 0,5 & 0,3 & 0,8 & 0,2 & $-0,3$ \\
\hline $27 / 2$ & 930 & $-0,7$ & $-1,2$ & $-0,9$ & 0,7 & $-0,4$ & $-0,1$ & 1,2 & 0,4 & 0,3 & 0,9 & 0,1 & $-0,3$ \\
\hline $27 / 2$ & 1000 & $-0,7$ & $-1,0$ & $-1,0$ & 0,7 & $-0,4$ & $-0,4$ & 1,0 & 0,4 & 0,0 & 1,0 & 0,4 & 0,0 \\
\hline $27 / 2$ & 103 & $-0,2$ & $-1,3$ & $-1,1$ & 0,2 & $-1,0$ & $-0,9$ & 1,3 & 1,0 & 0,2 & 1,1 & 0,9 & $-0,2$ \\
\hline $27 / 2$ & 1100 & 0,0 & $-1,0$ & $-0,9$ & 0,0 & $-1,0$ & $-0,9$ & 1,0 & 1,0 & 0 , & 0,9 & 0,9 & $-0,1$ \\
\hline $27 / 2$ & 1130 & $-0,2$ & $-1,2$ & $-1,0$ & 0,2 & $-1,0$ & $-0,7$ & 1,2 & 1,0 & 0, & 1,0 & 0,7 & $-0,3$ \\
\hline $27 / 2$ & 1200 & 0,0 & $-0,7$ & $-0,6$ & 0,0 & $-0,7$ & $-0,6$ & 0,7 & 0,7 & 0,0 & 0,6 & 0,6 & 0,0 \\
\hline $27 / 2$ & 1230 & $-0,2$ & $-0,7$ & $-0,8$ & 0,2 & $-0,6$ & $-0,7$ & 0,7 & 0,6 & $-0,1$ & 0,8 & 0,7 & 0,1 \\
\hline $27 / 2$ & 13 & 0,0 & $-1,0$ & $-0,8$ & 0,0 & $-1,0$ & $-0,8$ & 1,0 & 1,0 & 0,2 & 0,8 & 0,8 & $-0,2$ \\
\hline $27 / 2$ & 1330 & 0,5 & $-1,5$ & $-0,5$ & $-0,5$ & $-2,1$ & $-1,0$ & 1,5 & 2,1 & 1,1 & 0,5 & 1,0 & $-1,1$ \\
\hline $27 / 2$ & 1400 & 1,6 & $-1,1$ & $-0,7$ & $-1,6$ & $-2,7$ & $-2,3$ & 1,1 & 2,7 & 0,4 & 0,7 & 2,3 & $-0,4$ \\
\hline $27 / 2$ & 1430 & 0,3 & $-2,5$ & $-0,7$ & $-0,3$ & $-2,8$ & $-1,0$ & 2,5 & 2,8 & 1,8 & 0,7 & 1,0 & $-1,8$ \\
\hline $27 / 2$ & 1500 & 0,7 & $-2,3$ & $-0,7$ & $-0,7$ & $-3,0$ & $-1,4$ & 2,3 & 3,0 & 1,6 & 0,7 & 1,4 & $-1,6$ \\
\hline $27 / 2$ & 15 & 0 , & $-2,8$ & $-0,9$ & $-0,2$ & $-3,0$ & $-1,1$ & 2,8 & 3,0 & 1,9 & 0,9 & 1,1 & $-1,9$ \\
\hline $27 / 2$ & 1 & $-0,3$ & $-2,7$ & $-1,0$ & 0,3 & $-2,4$ & $-0,7$ & 2,7 & 2,4 & 1,7 & 1,0 & 0,7 & $-1,7$ \\
\hline $27 / 2$ & 163 & 0,5 & $-1,7$ & $-0,6$ & $-0,5$ & $-2,2$ & $-1,1$ & 1,7 & 2,2 & 1,1 & 0,6 & 1,1 & $-1,1$ \\
\hline $27 / 2$ & 1700 & 1,3 & $-0,3$ & $-0,8$ & $-1,3$ & $-1,6$ & $-2,1$ & 0,3 & 1,6 & $-0,5$ & 0,8 & 2,1 & 0,5 \\
\hline $27 / 2$ & 1730 & 1,9 & $-0,5$ & $-0,6$ & $-1,9$ & $-2,5$ & $-2,5$ & 0,5 & 2,5 & $-0,1$ & 0,6 & 2,5 & 0,1 \\
\hline $27 / 2$ & 1800 & 0,8 & $-1,3$ & $-0,4$ & $-0,8$ & $-2,1$ & $-1,2$ & 1,3 & 2,1 & 0,9 & 0,4 & 1,2 & $-0,9$ \\
\hline $27 / 2$ & 183 & $-0,5$ & $-2,0$ & $-0,4$ & 0,5 & $-1,4$ & 0,1 & 2,0 & 1,4 & 1, & 0,4 & $-0,1$ & $-1,5$ \\
\hline $27 / 2$ & 1900 & $-0,4$ & $-1,4$ & $-0,5$ & 0,4 & $-1,0$ & $-0,1$ & 1,4 & 1,0 & 0,9 & 0,5 & 0,1 & $-0,9$ \\
\hline $27 / 2$ & 1930 & $-0,5$ & $-1,3$ & $-0,4$ & 0,5 & $-0,8$ & 0,1 & 1,3 & 0,8 & 0,9 & 0,4 & $-0,1$ & $-0,9$ \\
\hline $27 / 2$ & 2000 & $-0,5$ & $-1,5$ & $-0,5$ & 0,5 & $-1,0$ & 0,0 & 1,5 & 1,0 & 0,9 & 0,5 & 0,0 & $-0,9$ \\
\hline $27 / 2$ & 2030 & $-0,4$ & $-1,4$ & $-0,5$ & 0,4 & $-0,9$ & 0,0 & 1,4 & 0,9 & 0,9 & 0,5 & 0,0 & $-0,9$ \\
\hline $27 / 2$ & 2100 & $-0,4$ & $-1,2$ & $-0,6$ & 0,4 & $-0,8$ & $-0,2$ & 1,2 & 0,8 & 0,6 & 0,6 & 0,2 & $-0,6$ \\
\hline $27 / 2$ & 2130 & $-0,2$ & $-1,2$ & $-0,6$ & 0,2 & $-1,1$ & $-0,4$ & 1,2 & 1,1 & 0,7 & 0,6 & 0,4 & $-0,7$ \\
\hline $27 / 2$ & 2200 & $-0,1$ & $-1,3$ & $-0,6$ & 0,1 & $-1,2$ & $-0,5$ & 1,3 & 1,2 & 0,7 & 0,6 & 0,5 & $-0,7$ \\
\hline $27 / 2$ & 2230 & $-0,3$ & $-1,4$ & $-0,6$ & 0,3 & $-1,1$ & $-0,3$ & 1,4 & 1,1 & 0,8 & 0,6 & 0,3 & $-0,8$ \\
\hline $27 / 2$ & 2300 & $-0,3$ & $-1,2$ & $-0,5$ & 0,3 & $-1,0$ & $-0,3$ & 1,2 & 1,0 & 0,7 & 0,5 & 0,3 & $-0,7$ \\
\hline $27 / 2$ & 2330 & $-0,2$ & $-1,3$ & $-0,5$ & 0,2 & $-1,1$ & $-0,3$ & 1,3 & 1,1 & 0,8 & 0,5 & 0,3 & $-0,8$ \\
\hline $27 / 2$ & 2400 & $-0,1$ & $-1,3$ & $-0,5$ & 0,1 & $-1,2$ & $-0,4$ & 1,3 & 1,2 & 0,7 & 0,5 & 0,4 & $-0,7$ \\
\hline
\end{tabular}

Legenda: CI - Campus I; CII - Campus II; F - Fadisc; S - Samambaia 


\section{APÊNDICE I - DIFERENÇA DE TEMPERATURA ENTRE AS ESTAÇÕES CLIMÁTICAS NO DIA 28/02/2005.}

\begin{tabular}{|c|c|c|c|c|c|c|c|c|c|c|c|c|c|}
\hline dia & hora & $\begin{array}{l}\text { ఫ్ } \\
\text { ú }\end{array}$ & $\frac{5}{1}$ & U & $\begin{array}{l}\underset{1}{\tilde{J}} \\
\end{array}$ & $\stackrel{5}{\frac{5}{3}}$ & $\stackrel{\hat{U}}{\bar{U}}$ & ర్ & $\underset{\mathrm{I}}{\bar{I}}$ & 䟞 & $\underset{\text { Ḋ }}{\bar{n}}$ & छ్ & $\frac{5}{1}$ \\
\hline $28 / 2$ & 30 & $\overline{2}$ & $-1,4$ & $-0,4$ & 0,2 & $-1,2$ & $-0,2$ & 1,4 & 1,2 & 1.0 & 0,4 & 0,2 & $-1,0$ \\
\hline $28 / 2$ & 100 & $-0,2$ & $-1,4$ & $-0,4$ & 0,2 & $-1,2$ & $-0,2$ & 1,4 & 1,2 & 1,0 & 0,4 & 0,2 & $-1,0$ \\
\hline $28 / 2$ & 130 & 0,0 & $-1,1$ & $-0,2$ & 0,0 & $-1,1$ & $-0,2$ & 1,1 & 1,1 & 0,9 & 0,2 & 0,2 & $-0,9$ \\
\hline $28 / 2$ & 200 & 0,3 & $-0,9$ & $-0,1$ & $-0,3$ & $-1,1$ & $-0,4$ & 0,9 & 1,1 & 0,7 & 0,1 & 0,4 & $-0,7$ \\
\hline $28 / 2$ & 230 & 0,0 & $-1,0$ & $-0,3$ & 0,0 & $-1,0$ & $-0,3$ & 1,0 & 1,0 & 0,6 & 0,3 & 0,3 & $-0,6$ \\
\hline $28 / 2$ & 300 & $-0,1$ & $-1,1$ & $-0,3$ & 0,1 & $-1,0$ & $-0,3$ & 1,1 & 1,0 & 0,8 & 0,3 & 0,3 & $-0,8$ \\
\hline $28 / 2$ & 330 & 0,0 & $-1,1$ & $-0,3$ & 0,0 & $-1,1$ & $-0,3$ & 1,1 & 1,1 & 0,8 & 0,3 & 0,3 & $-0,8$ \\
\hline $28 / 2$ & 400 & $-0,1$ & $-1,1$ & $-0,3$ & 0,1 & $-0,9$ & $-0,2$ & 1,1 & 0,9 & 0,8 & 0,3 & 0,2 & $-0,8$ \\
\hline $28 / 2$ & 430 & 0,0 & $-1,1$ & $-0,3$ & 0,0 & $-1,1$ & $-0,3$ & 1,1 & 1,1 & 0,8 & 0,3 & 0,3 & $-0,8$ \\
\hline $28 / 2$ & 500 & 0,1 & $-1,0$ & $-0,1$ & $-0,1$ & $-1,1$ & $-0,2$ & 1,0 & 1,1 & 0,9 & 0,1 & 0,2 & $-0,9$ \\
\hline $28 / 2$ & 53 & 0,1 & $-1,0$ & $-0,1$ & $-0,1$ & $-1,1$ & $-0,2$ & 1,0 &, 1 & 0,8 & 0,1 &, 2 & $-0,8$ \\
\hline $28 / 2$ & 600 & 0,3 & $-1,0$ & $-0,1$ & $-0,3$ & $-1,3$ & $-0,5$ & 1,0 & 1,3 & 0,8 & 0,1 &, 5 & $-0,8$ \\
\hline $28 / 2$ & 630 & 0,3 & $-0,9$ & $-0,2$ & $-0,3$ & $-1,3$ & $-0,5$ & 0,9 & 1,3 & 0,7 & 0,2 & 0,5 & $-0,7$ \\
\hline $28 / 2$ & 700 & $-0,2$ & $-1,0$ & $-0,5$ & 0,2 & $-0,8$ & $-0,3$ & 1,0 & 0,8 & 0,5 & 0,5 & 0,3 & $-0,5$ \\
\hline $28 / 2$ & 730 & $-0,1$ & $-1,1$ & $-0,3$ & 0,1 & $-0,9$ & $-0,2$ & 1,1 & 0,9 & 0,7 & 0,3 & 0,2 & $-0,7$ \\
\hline $28 / 2$ & 80 & $-0,3$ & $-1,3$ & $-0,5$ & 0,3 & $-1,0$ & $-0,1$ & 1, & 1, & 0,9 & 0,5 & 0,1 & $-0,9$ \\
\hline $28 / 2$ & 830 & $-0,9$ & $-2,3$ & $-0,7$ & 0,9 & $-1,3$ & 0,2 & 2 & 1, & 1,5 & 0,7 & $-0,2$ & $-1,5$ \\
\hline $28 / 2$ & 900 & $-0,2$ & $-1,7$ & $-0,6$ & 0,2 & $-1,4$ & $-0,4$ & 1,7 & 1,4 & 1,0 & 0,6 & 0,4 & $-1,0$ \\
\hline $28 / 2$ & 930 & $-0,2$ & $-1,0$ & $-0,6$ & 0,2 & $-0,8$ & $-0,4$ & 1,0 & 0,8 & 0,5 & 0,6 & 0,4 & $-0,5$ \\
\hline $28 / 2$ & 1000 & $-0,6$ & $-1,3$ & $-0,8$ & 0.6 & $-0,7$ & $-0,2$ & 1.3 & 0,7 & 0,5 & 0,8 & 0,2 & $-0,5$ \\
\hline $28 / 2$ & 1030 & $-0,7$ & $-1,4$ & $-1,0$ & 0,7 & $-0,6$ & $-0,3$ & 1,4 & 0,6 & 0,4 & 1,0 & 0,3 & $-0,4$ \\
\hline $28 / 2$ & 110 & $-0,4$ & -1.3 & -1.0 & 0,4 & -0.9 & -0.6 & 1.3 & 0.9 & 0,3 & 1.0 & 0.6 & $-0,3$ \\
\hline $28 / 2$ & 1130 & 0,0 & $-0,9$ & $-0,6$ & 0,0 & $-0,8$ & $-0,6$ & 0 , & 0 & 0,3 & 0, & 0,6 & $-0,3$ \\
\hline $28 / 2$ & 1200 & $-0,3$ & $-0,7$ & $-1,0$ & 0,3 & $-0,4$ & $-0,7$ & 0,7 & 0,4 & $-0,3$ & 1,0 & 0,7 & 0,3 \\
\hline $28 / 2$ & 1230 & $-0,7$ & $-0,9$ & $-1,1$ & 0,7 & $-0,2$ & $-0,4$ & 0,9 & 0,2 & $-0,2$ & 1,1 & 0,4 & 0,2 \\
\hline $28 / 2$ & 1300 & 0,2 & $-0,2$ & $-0,8$ & $-0,2$ & $-0,4$ & $-1,0$ & 0,2 & 0,4 & $-0,7$ & 0,8 & 1,0 & 0,7 \\
\hline $28 / 2$ & 13 & 0,2 & 0,2 & $-0,4$ & $-0,2$ & 0,0 & $-0,6$ & $-0,2$ & 0,0 & 0 & 0,4 & & 0,6 \\
\hline $28 / 2$ & 1400 & $-1,2$ & $-0,7$ & $-1,2$ & 1,2 & 0,4 & $-0,1$ & 0,7 & $-0,4$ & $-0,5$ & 1,2 & 0 & 0,5 \\
\hline $28 / 2$ & 1430 & $-0,3$ & $-0,6$ & $-0,8$ & 0,3 & $-0,3$ & $-0,5$ & 0,6 & 0,3 & $-0,2$ & 0,8 & 0,5 & 0,2 \\
\hline $28 / 2$ & 1500 & 0,0 & 0 , & $-0,9$ & 0,0 & $-0,1$ & $-0,9$ & 0,0 & 0,1 & $-0,9$ & 0,9 & 0,9 & 0,9 \\
\hline $28 / 2$ & 1530 & 0,3 & $-0,7$ & $-0,4$ & $-0,3$ & $-1,0$ & $-0,7$ & 0,7 & 1,0 & 0,3 & 0,4 & 0,7 & $-0,3$ \\
\hline $28 / 2$ & 16 & 0,5 & $-0,8$ & $-0,2$ & $-0,5$ & $-1,3$ & $-0,6$ & 0, & 1, & 0,6 & 0,2 & 0,6 & $-0,6$ \\
\hline $28 / 2$ & 16 & 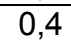 & $-1,1$ & $-0,3$ & $-0,4$ & $-1,5$ & $-0,7$ & 1 , & 1 & 0,8 & 0,3 & 0,7 & $-0,8$ \\
\hline $28 / 2$ & 1700 & 0 & $-1,7$ & $-0,6$ & $-0,1$ & $-1,8$ & $-0,7$ & 1,7 & 1,8 & 1,1 & 0 & 0,7 & $-1,1$ \\
\hline $28 / 2$ & 1730 & 0,7 & $-0,8$ & $-0,3$ & $-0,7$ & $-1,6$ & $-1,0$ & 0,8 & 1,6 & 0,5 & 0,3 & 1,0 & $-0,5$ \\
\hline $28 / 2$ & 1800 & $-0,2$ & $-1,1$ & $-0,5$ & 0,2 & $-0,9$ & $-0,3$ & 1,1 & 0,9 & 0,6 & 0,5 & 0,3 & $-0,6$ \\
\hline $28 / 2$ & 183 & 0,0 & $-1,0$ & $-0,8$ & 0,0 & $-1,0$ & $-0,8$ & 1, & 1 & 0,2 & 0,8 & 0,8 & $-0,2$ \\
\hline $28 / 2$ & 19 & 0,3 & $-0,9$ & $-0,7$ & $-0,3$ & $-1,2$ & $-0,9$ & 0, & 1, & 0,3 & 0,7 & 0,9 & $-0,3$ \\
\hline $28 / 2$ & 19 & & $-0,8$ & $-0,4$ & $-0,1$ & $-0,9$ & $-0,5$ & 0, & 0,9 & 0,4 & 0,4 & 5 & $-0,4$ \\
\hline $28 / 2$ & 2000 & $-0,3$ & $-1,0$ & $-0,4$ & 0,3 & $-0,7$ & $-0,1$ & 1,0 & 0,7 & 0,6 & 0,4 & 0,1 & $-0,6$ \\
\hline $28 / 2$ & 2030 & $-0,6$ & $-1,4$ & $-0,3$ & 0,6 & $-0,8$ & 0,3 & 1,4 & 0,8 & 1,1 & 0,3 & $-0,3$ & $-1,1$ \\
\hline $28 / 2$ & 2100 & $-0,9$ & $-1,7$ & $-0,1$ & 0,9 & $-0,9$ & 0,8 & 1,7 & 0,9 & 1,7 & 0,1 & $-0,8$ & $-1,7$ \\
\hline $28 / 2$ & 2130 & $-1,1$ & $-1,9$ & 0,0 & 1,1 & $-0,8$ & 1,1 & 1,9 & 0,8 & 1,8 & 0,0 & $-1,1$ & $-1,8$ \\
\hline $28 / 2$ & 2200 & $-1,3$ & $-1,7$ & 0.0 & 1,3 & $-0,4$ & 1,3 & 1,7 & 0, & 1.7 & 0.0 & $-1,3$ & $-1,7$ \\
\hline $28 / 2$ & 22 & -0 & $-1,0$ & & 0,8 & $-0,3$ & 1,2 & 1,0 & 0,3 & 1,4 & $-0,4$ & $-1,2$ & $-1,4$ \\
\hline $28 / 2$ & 2300 & $-1,2$ & $-1,1$ & 0,1 & 1,2 & 0,1 & 1,3 & 1,1 & $-0,1$ & 1,2 & $-0,1$ & $-1,3$ & $-1,2$ \\
\hline $28 / 2$ & 2330 & $-0,8$ & $-0,8$ & 0,2 & 0,8 & $-0,1$ & 1,0 & 0,8 & 0,1 & 1,0 & $-0,2$ & $-1,0$ & $-1,0$ \\
\hline $28 / 2$ & 2400 & $-0,6$ & $-0,4$ & 0,5 & 0,6 & 0,1 & 1,1 & 0,4 & $-0,1$ & 1,0 & $-0,5$ & $-1,1$ & $-1,0$ \\
\hline
\end{tabular}

Legenda: CI - Campus I; CII - Campus II; F - Fadisc; S - Samambaia 


\section{APÊNDICE J - DIFERENÇA DE TEMPERATURA ENTRE AS ESTAÇÕES CLIMÁTICAS NO DIA 01/03/2005.}

\begin{tabular}{|c|c|c|c|c|c|c|c|c|c|c|c|c|c|}
\hline dia & hora & U్ & $\frac{\pi}{u}$ & $\frac{0}{0}$ & 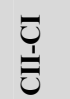 & $\stackrel{5}{\bar{J}}$ & 芳 & $\underset{\mathcal{I}}{\bar{I}}$ & $\underset{I}{E}$ & 望 & $\underset{n}{\tilde{D}}$ & ప్ & 步 \\
\hline $1 / 3$ & 30 & $-0,8$ & $-0,4$ & 0,4 & 0,8 & 0,4 & 1,2 & 0,4 & $-0,4$ & 0,8 & $-0,4$ & $-1,2$ & $-0,8$ \\
\hline $1 / 3$ & 100 & 0,1 & $-0,3$ & 0,5 & $-0,1$ & $-0,4$ & 0,4 & 0,3 & 0,4 & 0,8 & $-0,5$ & $-0,4$ & $-0,8$ \\
\hline $1 / 3$ & 130 & $-0,5$ & $-0,3$ & 0,6 & 0,5 & 0,3 & 1,1 & 0,3 & $-0,3$ & 0,8 & $-0,6$ & $-1,1$ & $-0,8$ \\
\hline $1 / 3$ & 200 & $-0,6$ & $-0,2$ & 0,8 & 0,6 & 0,5 & 1,4 & 0,2 & $-0,5$ & 0,9 & $-0,8$ & $-1,4$ & $-0,9$ \\
\hline $1 / 3$ & 230 & $-0,7$ & 0,2 & 1,0 & 0,7 & 0,9 & 1,8 & $-0,2$ & $-0,9$ & 0,9 & $-1,0$ & $-1,8$ & $-0,9$ \\
\hline $1 / 3$ & 300 & 0,2 & 0,7 & 1,5 & $-0,2$ & 0,5 & 1,4 & $-0,7$ & $-0,5$ & 0,8 & $-1,5$ & $-1,4$ & $-0,8$ \\
\hline $1 / 3$ & 330 & 0,0 & 1,1 & 1,7 & 0,0 & 1,0 & 1,7 & $-1,1$ & $-1,0$ & 0,6 & $-1,7$ & $-1,7$ & $-0,6$ \\
\hline $1 / 3$ & 400 & 0,2 & 0,8 & 1,2 & $-0,2$ & 0,5 & 0,9 & $-0,8$ & $-0,5$ & 0,4 & $-1,2$ & $-0,9$ & $-0,4$ \\
\hline $1 / 3$ & 430 & $-0,3$ & 0,6 & 1,2 & 0,3 & 0,9 & 1,5 & $-0,6$ & $-0,9$ & 0,6 & $-1,2$ & $-1,5$ & $-0,6$ \\
\hline $1 / 3$ & 500 & $-0,1$ & 0,5 & 1,2 & 0,1 & 0,6 & 1,4 & $-0,5$ & $-0,6$ & 0,7 & $-1,2$ & $-1,4$ & $-0,7$ \\
\hline $1 / 3$ & 530 & 0,0 & 0,6 & 1,4 & 0,0 & 0,6 & 1,4 & $-0,6$ & $-0,6$ & 0,8 & $-1,4$ & $-1,4$ & $-0,8$ \\
\hline $1 / 3$ & 600 & 0,2 & 1,0 & 1,1 & $-0,2$ & 0,7 & 0,8 & $-1,0$ & $-0,7$ & 0,1 & $-1,1$ & $-0,8$ & $-0,1$ \\
\hline $1 / 3$ & 630 & 0,2 & 1,1 & 1,6 & $-0,2$ & 0,9 & 1,4 & $-1,1$ & $-0,9$ & 0,5 & $-1,6$ & $-1,4$ & $-0,5$ \\
\hline $1 / 3$ & 700 & $-0,5$ & 1,1 & 1,5 & 0,5 & 1,5 & 2,0 & $-1,1$ & $-1,5$ & 0,5 & $-1,5$ & $-2,0$ & $-0,5$ \\
\hline $1 / 3$ & 730 & $-1,4$ & 0,6 & 0,7 & 1,4 & 2,0 & 2,2 & $-0,6$ & $-2,0$ & 0,2 & $-0,7$ & $-2,2$ & $-0,2$ \\
\hline $1 / 3$ & 800 & $-1,3$ & $-0,5$ & $-1,2$ & 1,3 & 0,8 & 0,1 & 0,5 & $-0,8$ & $-0,7$ & 1,2 & $-0,1$ & 0,7 \\
\hline $1 / 3$ & 830 & $-2,4$ & $-1,5$ & $-2,1$ & 2,4 & 0,8 & 0,3 & 1,5 & $-0,8$ & $-0,6$ & 2,1 & $-0,3$ & 0,6 \\
\hline $1 / 3$ & 900 & $-1,6$ & $-1,9$ & $-1,9$ & 1,6 & $-0,3$ & $-0,3$ & 1,9 & 0,3 & 0,0 & 1,9 & 0,3 & 0,0 \\
\hline $1 / 3$ & 930 & $-0,8$ & $-1,7$ & $-1,4$ & 0,8 & $-0,9$ & $-0,6$ & 1,7 & 0,9 & 0,3 & 1,4 & 0,6 & $-0,3$ \\
\hline $1 / 3$ & 1000 & $-1,4$ & $-1,6$ & $-1,8$ & 1,4 & $-0,2$ & $-0,4$ & 1,6 & 0,2 & $-0,2$ & 1,8 & 0,4 & 0,2 \\
\hline $1 / 3$ & 1030 & $-1,4$ & $-1,7$ & $-1,7$ & 1,4 & $-0,2$ & $-0,3$ & 1,7 & 0,2 & 0,0 & 1,7 & 0,3 & 0,0 \\
\hline $1 / 3$ & 110 & $-0,7$ & $-1,6$ & $-1,4$ & 0,7 & $-0,9$ & $-0,6$ & 1,6 & 0,9 & 0 , & 1,4 & 0,6 & $-0,3$ \\
\hline $1 / 3$ & 1130 & $-0,3$ & $-1,6$ & $-0,9$ & 0,3 & $-1,3$ & $-0,6$ & 1,6 & 1,3 & 0, & 0,9 & 0,6 & $-0,7$ \\
\hline $1 / 3$ & 1200 & $-0,5$ & $-1,6$ & $-1,4$ & 0,5 & $-1,1$ & $-0,9$ & 1,6 & 1,1 & 0, & 1,4 & 0,9 & $-0,2$ \\
\hline $1 / 3$ & 1230 & $-0,8$ & $-1,6$ & $-0,8$ & 0,8 & $-0,8$ & 0,0 & 1,6 & 0,8 & 0,8 & 0,8 & 0,0 & $-0,8$ \\
\hline $1 / 3$ & 1300 & $-1,2$ & $-2,2$ & $-1,6$ & 1,2 & $-1,0$ & $-0,4$ & 2,2 & 1,0 & 0,6 & 1,6 & 0,4 & $-0,6$ \\
\hline $1 / 3$ & 1 & 0,1 & $-0,9$ & $-1,0$ & $-0,1$ & $-0,9$ & $-1,0$ & 0,9 & 0,9 & -0 , & 1,0 & 1,0 & 0,1 \\
\hline $1 / 3$ & 1400 & $-0,1$ & $-1,3$ & $-1,2$ & 0,1 & $-1,2$ & $-1,1$ & 1,3 & 1,2 & 0 & 1,2 & 1,1 & $-0,1$ \\
\hline $1 / 3$ & 1430 & 0,2 & $-1,2$ & $-1,0$ & $-0,2$ & $-1,5$ & $-1,3$ & 1,2 & 1,5 & 0,2 & 1,0 & 1,3 & $-0,2$ \\
\hline $1 / 3$ & 1500 & 0,2 & $-1,2$ & $-0,9$ & $-0,2$ & $-1,4$ & $-1,0$ & 1,2 & 1,4 & 0,3 & 0,9 & 1,0 & $-0,3$ \\
\hline $1 / 3$ & 1530 & $-0,6$ & $-1,3$ & $-0,9$ & 0,6 & $-0,7$ & $-0,2$ & 1,3 & 0,7 & 0,4 & 0,9 & 0,2 & $-0,4$ \\
\hline $1 / 3$ & 16 & $-0,5$ & $-1,1$ & $-0,9$ & 0,5 & $-0,6$ & $-0,4$ & 1,1 & 0,6 & 0,2 & 0,9 & 0,4 & $-0,2$ \\
\hline $1 / 3$ & 16 & 0 & $-0,8$ & $-0,9$ & 0,0 & $-0,8$ & $-0,9$ & 0,8 & 0,8 & 0,0 & 0,9 & 0,9 & 0,0 \\
\hline $1 / 3$ & 1700 & $-0,2$ & $-1,4$ & $-0,9$ & 0,2 & $-1,2$ & $-0,8$ & 1,4 & 1,2 & 0,5 & 0,9 & 0,8 & $-0,5$ \\
\hline $1 / 3$ & 1730 & $-0,4$ & $-1,4$ & $-1,0$ & 0,4 & $-1,0$ & $-0,6$ & 1,4 & 1,0 & 0,4 & 1,0 & 0,6 & $-0,4$ \\
\hline $1 / 3$ & 1800 & $-0,3$ & $-1,7$ & $-1,1$ & 0,3 & $-1,4$ & $-0,8$ & 1,7 & 1,4 & 0,6 & 1,1 & 0,8 & $-0,6$ \\
\hline $1 / 3$ & 1830 & 0,2 & $-1,3$ & $-0,6$ & $-0,2$ & $-1,5$ & $-0,9$ & 1,3 & 1,5 & 0,7 & 0,6 & 0,9 & $-0,7$ \\
\hline $1 / 3$ & 190 & 0 & $-1,2$ & $-0,5$ & $-0,2$ & $-1,4$ & $-0,8$ & 1,2 & 1,4 & 0,7 & 0,5 & 0,8 & $-0,7$ \\
\hline $1 / 3$ & 193 & 0 & $-1,3$ & $-0,5$ & 0,0 & $-1,3$ & $-0,5$ & 1,3 & 1,3 & 0,8 & 0,5 & 0,5 & $-0,8$ \\
\hline $1 / 3$ & 2000 & 0,3 & $-1,3$ & $-0,5$ & $-0,3$ & $-1,7$ & $-0,9$ & 1,3 & 1,7 & 0,8 & 0,5 & 0,9 & $-0,8$ \\
\hline $1 / 3$ & 2030 & 0,3 & $-1,2$ & $-0,5$ & $-0,3$ & $-1,5$ & $-0,8$ & 1,2 & 1,5 & 0,7 & 0,5 & 0,8 & $-0,7$ \\
\hline $1 / 3$ & 2100 & 0,1 & $-1,2$ & $-0,5$ & $-0,1$ & $-1,3$ & $-0,6$ & 1,2 & 1,3 & 0,6 & 0,5 & 0,6 & $-0,6$ \\
\hline $1 / 3$ & 2130 & 0,0 & $-1,2$ & $-0,5$ & 0,0 & $-1,2$ & $-0,5$ & 1,2 & 1,2 & 0,7 & 0,5 & 0,5 & $-0,7$ \\
\hline $1 / 3$ & 2200 & 0,1 & $-1,2$ & $-0,5$ & $-0,1$ & $-1,2$ & $-0,6$ & 1.2 & 1,2 & 0,6 & 0,5 & 0.6 & $-0,6$ \\
\hline $1 / 3$ & 2230 & $-0,1$ & $-1,2$ & $-0,5$ & 0,1 & $-1,1$ & $-0,4$ & 1,2 & 1,1 & 0,7 & 0,5 & 0,4 & $-0,7$ \\
\hline $1 / 3$ & 2300 & $-0,2$ & $-1,2$ & $-0,5$ & 0,2 & $-1,0$ & $-0,3$ & 1,2 & 1,0 & 0,6 & 0,5 & 0,3 & $-0,6$ \\
\hline $1 / 3$ & 2330 & $-0,3$ & $-1,1$ & $-0,5$ & 0,3 & $-0,8$ & $-0,2$ & 1,1 & 0,8 & 0,6 & 0,5 & 0,2 & $-0,6$ \\
\hline $1 / 3$ & 2400 & $-0,4$ & $-1,2$ & $-0,6$ & 0,4 & $-0,8$ & $-0,2$ & 1,2 & 0,8 & 0,6 & 0,6 & 0,2 & $-0,6$ \\
\hline
\end{tabular}

Legenda: CI - Campus I; CII - Campus II; F - Fadisc; S - Samambaia 
